UNIVERSIDADE DE SÃO PAULO

FFCLRP - DEPARTAMENTO DE PSICOLOGIA E EDUCAÇÃO

PROGRAMA DE PÓS-GRADUAÇÃO EM PSICOLOGIA

\title{
Desvelando a dor amorosa da infidelidade conjugal: discursos de homens e mulheres
}

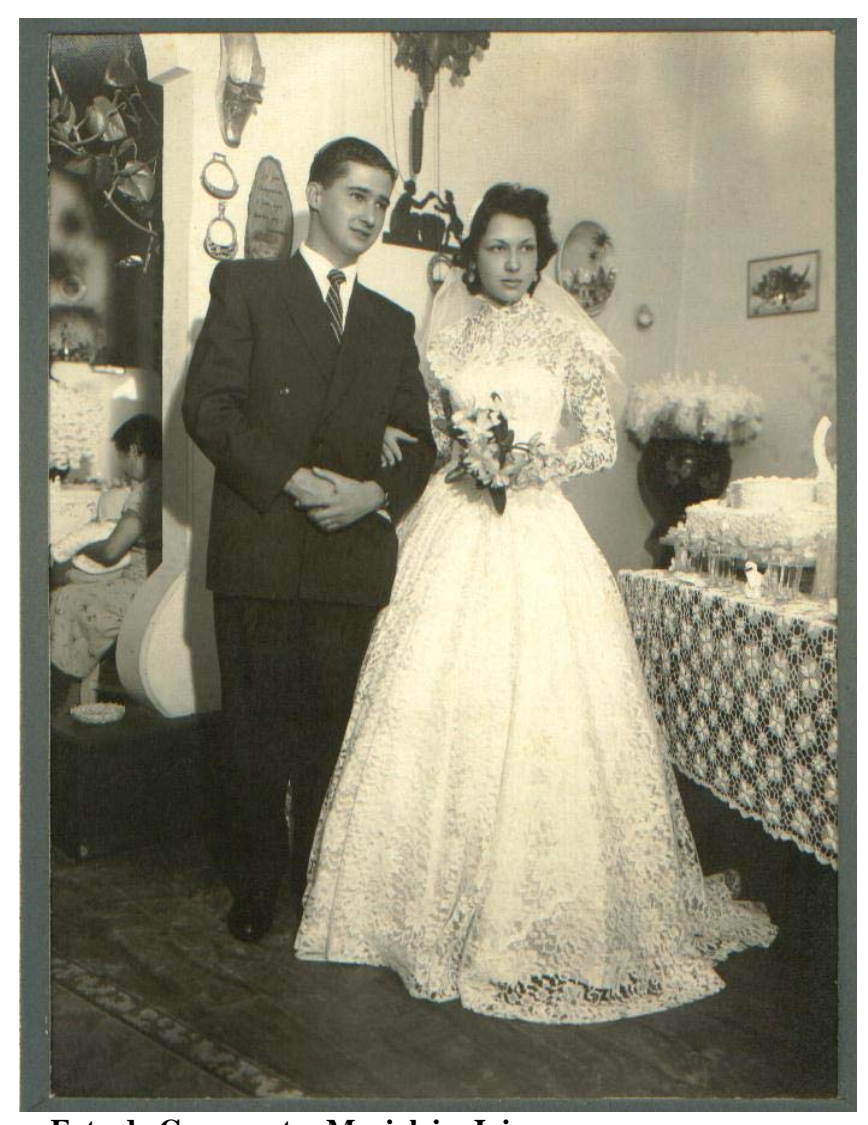

Foto de Casamento: Marialci e Jair

\section{Edilaine Helena Scabello}

Dissertação apresentada à Faculdade de Filosofia, Ciências e Letras de Ribeirão Preto, da Universidade de São Paulo - USP, como parte das exigências para a obtenção do título de Mestre em Ciências, Área: Psicologia 
Foto de Casamento: Marialci e Jair 
UNIVERSIDADE DE SÃO PAULO

FFCLRP - DEPARTAMENTO DE PSICOLOGIA E EDUCAÇÃO

PROGRAMA DE PÓS-GRADUAÇÃO EM PSICOLOGIA

Desvelando a dor amorosa da infidelidade conjugal:

discursos de homens e mulheres

Edilaine Helena Scabello

Orientadora: Profa. Dra. Maria Alves de Toledo Bruns

Dissertação apresentada à Faculdade de Filosofia, Ciências e Letras de Ribeirão Preto da Universidade de São Paulo - USP, como parte das exigências para a obtenção do título de Mestre em Ciências, Área: Psicologia.

RIBEIRÃO PRETO - SP 


\section{FICHA CATALOGRÁFICA}

Scabello, Edilaine Helena

Desvelando a dor amorosa da infidelidade conjugal: discursos de homens e mulheres. Ribeirão Preto, 2006.

327 p. : il. ; $30 \mathrm{~cm}$

Dissertação, apresentada à Faculdade de Filosofia, Ciências e Letras de Ribeirão Preto / USP - Dep. de Psicologia e Educação.

Orientador: Bruns, Maria Alves de Toledo

1. Infidelidade amorosa. 2. Dor psíquica. 3. Re-significação.

4. Fenomenologia. 5. Psicanálise. 


\section{FOLHA DE APROVAÇÃO}

Edilaine Helena Scabello

Desvelando a dor amorosa da infidelidade conjugal: discursos de homens e mulheres

Dissertação apresentada à Faculdade de Filosofia, Ciências e Letras de Ribeirão Preto, da Universidade de São Paulo - USP, como parte das exigências para a obtenção do título de Mestre em Ciências, Área: Psicologia

Aprovada em

Banca Examinadora

Prof (a). Dr (a).

Instituição: Assinatura:

Prof (a). Dr (a).

Instituição: Assinatura:

Prof (a). Dr (a).

Instituição: Assinatura: 
Aos meus pais, que me envolveram, me ajudaram a dar os primeiros passos e me ensinaram ao longo da minha existência que a honestidade e a verdade estão acima de qualquer virtude. Dedico esse trabalho com amor, admiração e gratidão pelo incansável apoio e pela alegre presença que eles são em minha vida. 


\section{AGRADECIMENTOS}

"Encontramo-nos, em cada momento da vida, em nossa experiência cotidiana, tendo com ela uma familiaridade imediata pré-reflexiva que não provém daquilo que a ciência nos ensina. É a partir e dentro dessa vivencia diária que desenvolvemos todas as nossas atividades, inclusive as científicas, e que determinamos nossos objetivos e ideais. A experiência cotidiana imediata é o cenário do qual decorre a nossa vida; ser-no-mundo é a sua estrutura fundamental”.

\section{Yolanda Cintrão Forghieri}

No decorrer dos quatro anos de desenvolvimento desse trabalho me senti como se eu fosse uma passageira de “trem”. Durante todo o percurso, algumas pessoas me acompanharam e outras me deixaram, em tantas outras “estações”, as quais posso chamar de “idéias”, tão diferentes daquelas as quais eu pretendia chegar. Nessa trajetória, algumas pessoas se casaram, outras nasceram e alguns de meus afetos adoeceram. Alguns dos seus passageiros contaram-me histórias e atribuíram significados às suas "pousadas”. Reencontrei pessoas conhecidas e também engendrei novos encontros. Algumas "estações” ou "idéias" foram para mim mais significativas que outras, pois suas "paisagens" eram percebidas como as mais belas telas das quais nunca as tinha visto.

Ao longo desse caminho, senti muitas vezes vontade de abandonar o "trem”, o qual posso chamar de “trabalho”, quando a “viagem” incansável chegava ao limiar suportável de minha motivação, do meu entusiasmo e do meu cansaço. Por fim, compreendi que a realização dessa "viagem”, ou seja, a construção de uma “pesquisa cientifica”, não se dá somente entre as contribuições do pesquisador, do orientador e dos colaboradores, mas envolve a todos os passageiros do “trem”, que merecem ser agradecidos por terem compartilhado comigo a trajetória de uma viagem existencial, que tem aqui nesse trabalho apenas um ponto de parada, nem a partida e nem a chegada.

É lugar-comum agradecer de maneira especial ao orientador. “Cara orientadora Profa. Dra. Maria Alves de Toledo Bruns agradeço por ter me inspirado teoricamente, ter respondido as minhas dúvidas e indagações e ter trilhado comigo um caminho que não foi somente meu ou seu, mas nosso". 
Aos(as) colaboradores(as): Isolda, Bárbara, Stela, Flor de Liz, Verônica, Romeu, Ulisses, Aquiles e Paris que trouxeram uma história em cada um destes co-dinomes. “Obrigada por vocês terem se empenhado em compartilhar conosco os significados atribuídos aos seus afetos e às suas vivencias e, assim, serem a razão desse trabalho”.

À todos aqueles que me auxiliaram na contatação dos(das) colaboradores(as) e que, por razões éticas, a fim de preservar as identidades dos(das) entrevistados(as), não poderei citar os nomes.

Aos professores que compuseram a Banca do Exame de Qualificação: Prof. Dr. Francisco Haschimoto (Chico), docente da FCL, Unesp de Assis, SP, por quem tenho apreço e agradecimento por ter sido um grande mestre em meu curso de graduação em Psicologia. "Caro Chico, confesso que em sua imagem me espelho hoje, como professora de um curso de Psicologia”. Prof. Dr. Sérgio Kodato, docente da FFCLRP, USP, Ribeirão Preto, SP, por quem admiro a competência, inteligência e dedicação à pesquisa científica.

Aos demais professores da FCL, UNESP de Assis, SP que tiveram significativas influências nos rumos tomados por mim em relação à minha prática científica e acadêmica, bem como profissional: Prof. Dr. Luiz Carlos da Rocha, Profa. Dr. Maria de Fátima Araújo, Prof. Dr. Jorge Abraão, Prof. Dr. Nelson Pedro da Silva e Prof. Dr. Sílvio Yassui.

Aos integrantes do Grupo de Pesquisa Sexualidade e Vida. “Agradeço a vocês pela amizade, pelo companheirismo e por compartilhar saberes e experiências”.

Ao amigo Prof. Dr. Paulo Rennes Marçal Ribeiro, vice-diretor e docente da FCL, UNESP de Araraquara-SP, pela amizade e por promover a socialização de conhecimento entre o seu e o nosso grupo de pesquisa.

Aos funcionários da FFCLRP, USP, Ribeirão Preto, SP que sempre me instruíram e me orientaram em relação as normas e procedimentos associados ao Programa de pósgraduação em Psicologia, entre eles: Sônia, Isilda, Denise Santos e Denise Cremonezi. 
Àqueles que cederam suas fotos de família: Marialci e Jair, Aline e Luciano, Flávia e Sérgio, que ilustraram as apresentações do exame de qualificação e do exame de defesa e a capa deste trabalho.

Ao amigo Prof. Dr. Francisco da Silva Borba, Presidente do Centro de Educação Especial, da Associação de Atendimento Educacional Especializado, em Araraquara-SP, lugar em que iniciei a minha trajetória como psicóloga e no qual ainda me encontro. “Agradeço a você pela confiança depositada em meu primeiro emprego e pela oportunidade de ter vivido nesse trabalho trocas de afetos, experiências e um grande processo de amadurecimento que, ultrapassaram as fronteiras teóricas que são apreendidas em nossa formação nos cursos de Psicologia. Agradeço ainda, pelas vezes que consentiu a minha ausência no trabalho quando precisei cursar as disciplinas exigidas pelo curso de mestrado, bem como a contribuição que me proporcionou na redação dessa investigação, quando pude consultar, por inúmeras vezes, o dicionário de português contemporâneo elaboradora por você”.

Agradeço a todos os meus colegas de trabalho e, em especial, à Flávia Elena Messias Bombo Calixto, por ter aceitado o convite de dividir comigo no "Centro de Educação Especial” as incumbências de psicóloga durante esse último ano. E por fim, agradeço aos "pequenos" e aos "grandes" deficientes mentais que me proporcionam afinar uma escuta capaz de compreender uma linguagem que vai além daquilo que possa ser verbalizado e verbalizável.

Aos colegas de trabalho do Instituto de Ensino Superior: “Dr. Aristides de Carvalho Schlobach” - ITES, em Taquaritinga, SP e aos meus alunos do curso de Psicologia, em especial, àqueles em que tivemos contatos mais estreitos, permeados pela empatia mútua, seja devido às necessidades de supervisão de estágio ou de aprendizagem.

Aos meus pais, Horácio e Dionéa, por terem acolhido as minhas angústias no decorrer desse árduo trabalho de pesquisa, o que foi necessário para que eu pudesse desenvolver essa investigação. Aliás, "vocês acolhem minhas angústias desde antes de eu nascer. Agradeço a você pai, por ter transmitido a mim a sua honestidade e a sua humildade, características tão marcantes em nós dois e, por estar sendo bravo nesse doloroso momento que estamos vivenciando. Agradeço a você mãe, na qual identifico o 
meu entusiasmo e coragem de enfrentar as dificuldades do dia-a-dia, pelo seu amor incondicional e por cuidar de nós nesse momento”.

Aos meus irmãos Fátima, Júnior, "Lê” e à minha cunhada Maria José que compartilharam comigo, durante o desenvolvimento desse trabalho, na alternância de vivências paradoxais de tranqüilidade e insegurança, os nobres sentimentos de amor e de dor, tão presentes em nossa querida família. Agradeço, em especial, ao caçula - "Lê” - que sempre dedicou a mim o seu carinho incondicional.

Aos demais familiares, também agradeço pelos momentos compartilhados e, em especial, ao Tio Elizeu e filhos que me receberam diversas vezes em sua casa quando precisava viajar para encontrar-me com a minha orientadora.

À amiga Andréa Cabral, pelas aulas de inglês e pela revisão de texto deste trabalho.

À grande amiga Fabiana Fernanda de Freitas, pela ajuda técnica nesse trabalho e aos demais amigos que, em tempos de individualidade, de frenesi e de hedonismo, mantêm viva a nossa amizade e participaram, de uma forma ou de outra, da composição dessa dissertação, entre os quais destaco Alda Landucci Moura, Alessandro Gianninni, Neuza Cervi da Costa, Rosita Barral, Valéria Bastos e Léia Comar Riva.

Entre todos os demais afetos, agradeço especialmente ao Fernando por me motivar e se manter presente no desenvolvimento final dessa investigação, renunciando a momentos que seriam nossos.

E, por fim, agradeço a Deus, que esteve presente na figura de cada uma dessas pessoas. 
"Para grupos, assim como para indivíduos,

A vida significa separação e reunião,

Mudanças de forma e condição, morte e renascimento.

É o agir e o cessar, esperar e repousar e então, começar a agir novamente, mas de modo diferente”.

Arnold Van Gennep

“O amor é um grande laço, um passo pr’a uma armadilha

Um lobo correndo em círculo pra alimentar a matilha

Comparo sua chegada com a fuga de uma ilha

Tanto engorda quanto mata feito desgosto de filha

O amor é como um raio, galopando em desafio

Abre fendas, cobre vales, revolta as águas dos rios

Quem tentar seguir seu rastro, se perderá no caminho

Na pureza de um limão ou na solidão do espinho

$\mathrm{O}$ amor e a agonia cerraram fogo no espaço

Brincando horas a fio, o cio vence o cansaço

E o coração de quem ama fica faltando um pedaço

Que nem a lua minguando, que nem o meu nos seus braços”.

Djavan

"Os intelectuais continuam sendo marteladores obstinados do sentido [...] Talvez o trabalho intelectual, por seu caráter insuperavelmente artesanal e apaixonado [amoureux], seja o que, aqui e ali, venha a opor a resistência mais obstinada à frivolidade ao porvir-espetáculo, do mundo”. 
SCABELLO, E. H. Desvelando a dor amorosa da infidelidade conjugal: discursos de homens e mulheres. 2006. 327 p. Dissertação (mestrado). FFCLRP - Universidade de São Paulo, Ribeirão Preto, 2006.

\section{RESUMO}

No cenário atual, as transformações sócio-culturais e tecnológicas vêm ampliando as fronteiras culturais entre as nações, acentuando a individualidade e redefinindo práticas afetivas. Assistimos a pulverização dos ideais de verdade, a desagregação das estruturas tradicionais de normatização, o excesso de liberdade, o hiper-consumismo, a valorização do novo e do hedonismo. Na aparente efemeridade das relações afetivas, buscamos compreender que significados homens e mulheres atribuem a vivencia da infidelidade amorosa da(do) parceira(o) e como re-significam suas relações amorosas após estes(estas) lhes terem sido infiéis. Entrevistamos 05 mulheres casadas pela Lei Civil e Igreja Católica, sendo que uma delas se separou após a infidelidade do parceiro e depois se reconciliou com ele; 04 homens, sendo que um deles se casou pela Lei Civil e Igreja Católica e se separou após a infidelidade da parceira; outro se uniu pelo contrato de conjunção marital e se separou após a infidelidade da parceira; e os outros dois, solteiros, se separaram das namoradas após a infidelidade delas. Utilizamos o método fenomenológico descritivo proposto por Rezende (1990) e obtivemos as descrições dos(das) colaboradores(as) mediante a questão: "Fale a respeito da sua relação afetiva e sexual no decorrer do seu casamento (namoro) e, em especial, após seu (sua) marido (esposa/namorada) lhe ter sido infiel". Submetemo-as aos momentos da análise propostos por Giorgi (1978) e Bruns (2003) e situamos o fenômeno em sua temporalidade e construção sócio-histórica, bem como realizamos sua compreensão psicológica à luz do referencial psicanalítico. Ao analisarmos as descrições compreendemos que, embora vivenciamos no campo familiar, a transgressão de regras, a ruptura de modelos e a pluralização de formas de se relacionar, presenciamos a persistência de elementos tradicionais coexistindo com os comportamentos contemporâneos, como o ideal de amor romântico que imprime as idealizações de felicidade nas parcerias. Percebemos que os desencantos vivenciados por homens e mulheres exprimem a quebra da idealidade frente à figura amada e se manifestam também, nas insatisfações sexuais. A dor psíquica desencadeada pela vivência da infidelidade do(a) parceiro(a) expressa a comoção pulsional ou autopercepção do eu sobre o tumulto interno desencadeado pela perda ou ruptura da imagem que o parceiro traído tem de quem lhe foi infiel e, ao mesmo tempo, pela ruptura de sua própria imagem, que gera confusão mental e dúvidas sobre a própria identidade e sanidade mental. A irrepresentabilidade da dor psíquica pelo eu é expressa tanto pela marca da subtaneidade da descoberta da infidelidade do(a) parceiro(a), quanto pela negação da realidade. A manifestação exterior de sintomas são refletidos em dores psicogênicas e revelam sentimentos como culpa, menos-valia, impotência, insegurança, mágoa, ressentimento, solidão, abandono, rejeição, falta de apoio familiar e social e falta de perspectiva futura, bem como a projeção da dor psíquica no(a) parceiro(a). Os valores, as regras e os mitos que regem um grupo familiar são transmitidos de pais para filhos e há uma relação entre a preocupação com os filhos e o desejo de separar-se do(da) parceiro(a). A dramática ligação entre ciúme e violência compõe o cenário das relações infiéis. Contudo, as re-significações existenciais frente à vivencia da infidelidade podem percorrer territórios psíquicos que se dirigem para duas instâncias, a reconstrução e/ou dissolução do relacionamento amoroso, na busca de vivencias prazerosas; o aprisionamento da dor que encerra o eu em um dilaceramento sem fim, preso a uma antiga imagem não re-significada do eleito amado.

Palavras chave: 1. Infidelidade amorosa. 2. Dor psíquica. 3. Re-significação. 4. Fenomenologia. 5. Psicanálise. 
SCABELLO, E. H. Revealing the loving pain of marital infidelity: men's and women's speeches. 2006. 327 p. Thesis (Master's Degree). FFCLRP - University of São Paulo, Ribeirão Preto, 2006.

\begin{abstract}
In the current scenery, socio-cultural and technological changes have been increasing cultural borders among the nations, accentuating individuality and redefinig affective practicals. We have watched the pulverization of the ideals of truth, the disaggregation of the traditional structures of normatization, the excess of freedom, the hiper-consumerism, the valorization of the new and of the hedonism. In the apparent efemerity of affective relationships, we attempt to understand which meanings men and women attribute to the existence of love infidelity of male or female partners and how they resignify their relationships after their partners' infidelity. We interviewed 05 women, married in the Civil Law and Catholic Church; one of them separated after the partner's infidelity and later reconciled to him; 04 men; one of them got married in the Civil Law and Catholic Church and separated after the partner's infidelity; another one joined in the contract of marital conjunction and separated after the partner's infidelity; and the other two single men, separated after their girlfriends' infidelity. We used the descriptive phenomenologic method proposed by Rezende (1990) and we obtained the descriptions by asking: "Talk about sex and love during your relationships an especially after your partners' infidelity”. We made our analysis according to Giorgi (1978) and Bruns (2003) and we placed the phenomenon in its temporality and sociohistorical construction and also accomplished its psychological understanding according to phyco analysis. To analyze the descriptions we understood that although we live in the familial field, the transgression of rules, the rupture of models and the pluralization relationships, we witness the persistence of traditional elements coexisting with contemporary behaviors, such as the ideal of romantic love in the idealization of happiness in the relationships. We noticed that disapointments experienced by men and women express the break of the ideal love and also appear in their sexual dissatisfactions. Psycic pain revealed by the existence of the partners' infidelity expresses the pulsional commotion or autoperception of the internal tumult resulting from the the loss or rupture of the image that the betrayed partner has of the unfaithful one, and at the same time, from the rupture of his/ her own image, which generates mental confusion and doubts about their own identity and mental sanity. The irrepresentability of the psychic pain is expressed in the discovery of partners' infidelity as well as in the denial of reality. The external manifestation of symptoms is reflected in the psycogenic pain which reveal feelings such as blame, low self-confidence, impotence, insecurity, sorrow, resentment, solitude, abandonment, rejection, lack of family and social support and lack of future perspective, as well as the projection of the psychic pain to the partners. The values, the rules and the myths that govern a family group are transmitted from $r$ parents to children and there is a relation between the concern with the children and the desire of separation. The dramatic connection between jealousy and violence composes the scenery of unfaithful relationships. However, the existential re-significances in the experience of infidelity can go through psychic territories that lead to two instances, the reconstruction and/ or breakup of the love relationship, in the search of pleasure; the imprisonment of pain that leads to endless suffering due to the non re-signified image of the partner.
\end{abstract}

Key words: 1. loving infidelity. 2. Psychic pain. 3. Re-significance. 4. Phenomenology. 5. Psycoanalysis. 


\section{SUMÁRIO}

Apresentação

CAPÍTLO 1 - O AMOR, O CASAMENTO E A SEXUALIDADE

1.1 O cenário sócio-cultural atual e as transformações da modernidade 12

1.2 A Igreja, o casamento e o amor: um confronto, um desencontro, um enlace 28

1.3. O surgimento da família burguesa, a sexualidade e a ascensão do ideal do amor romântico

1.4 A busca pelo ideal do amor romântico e o esvaziamento das trocas afetivas e sexuais inter-humanas: as configurações entre o estável e o efêmero

CAPÍTULO 2 - INFIDELIDADE: UMA LEI, UM PECADO, UM VALOR, UM ESQUECIMENTO, UMA GUERRA DE ESPERMAS?!

CAPÍTULO 3 - TRAJETÓRIA METODOLÓGICA QUALITATIVA

3.1 O que é uma investigação qualitativa?

3.2 A escolha pelo método 98

3.3. O método

3.3.1 Acesso aos depoimentos: a entrevista fenomenológica descritiva

3.3.2 Momentos da análise dos depoimentos

3.3.3 Os colaboradores (as)

Acesso aos (às) colaboradores (es) e as dificuldades encontradas no percurso

Perfil dos (das) colaboradores (as)

CAPÍTULO 4 - O TEMPORALIZAR DA INFIDELIDADE AMOROSA PELAS VOZES FEMININAS E MASCULINAS

4.1 Categorias e sub-categorias emergidas das descrições femininas

4.2 Categorias e sub-categorias emergidas das descrições masculinas

$4.3 \mathrm{O}$ temporalizar da infidelidade amorosa pelas vozes femininas

Isolda

Bárbara

Stela 
Verônica

4.4 O temporalizar da infidelidade amorosa pelas vozes masculinas 260

$\begin{array}{ll}\text { Romeu } & 261\end{array}$

$\begin{array}{ll}\text { Aquiles } & 272\end{array}$

Ulisses $\quad 286$

$\begin{array}{ll}\text { Páris } & 299\end{array}$

CAPÍTULO 5 - PERPLEXIDADE, DOR E LUTO: A RE-SIGNFICAÇÃO DO 311 AMOR E DA INFIDELIDADE VIVENCIADOS POR HOMENS E MULHERES

$\begin{array}{ll}\text { HORIZONTES } & 317\end{array}$

REFERÊNCIAS BIBLIOGRÁFICAS 319

ANEXOS I

Anexo A - Ofício de aprovação do projeto de pesquisa pelo comitê de ética da II FFCLRP - USP

Anexo B - Termo de consentimento livre e esclarecido III

Anexo C - Roteiro para obtenção de informações para caracterizar o perfil do(a) VII colaborador(a)

Anexo D - Questionário de classificação econômica $\quad$ VIII

Anexo E - Autorização para utilização, veiculação e reprodução de imagens IX fotográficas

Anexo F - Autorização para reprodução de imagens fotográficas no texto final da $\mathrm{X}$ pesquisa como elemento ilustrativo 


\section{LISTA DE TABELAS}

Tabela 1 - A idade de cada colaborador(a) e de seu(sua) respectivo(a) (ex) parceiro(a) 125 e o nível econômico da família.

Tabela 2 - A escolaridade e a área de atuação de cada colaborador(a) e de seu(sua) 125 respectivo (a) (ex) parceiro (a).

Tabela 3 - A religião de cada colaborador(a) e de seu(sua) respectivo(a) (ex) 126 parceiro(a), o número de filhos do casal, a idade e o sexo de cada um(uma) deles(as).

Tabela 4 - O tipo e o tempo de união de cada colaborador(a) com seu(sua) 126 respectivo(a) (ex) parceiro(a) e o tipo de separação e/ou de reconciliação daqueles que se separaram dos(das) parceiros(as) após a infidelidade destes(as). 


\section{APRESENTAÇÃO}

Formei-me em Psicologia pela Faculdade de Ciências e Letras da Universidade Estadual de São Paulo - Campus de Assis-SP (1995-1999). Desde o início do curso de graduação interessei-me pela pesquisa científica, desenvolvendo pesquisas de iniciação científica exigidas por disciplinas do currículo acadêmico, bem como realizadas em atividades extracurriculares. Dentre estas pesquisas destaco: “Um estudo das representações acerca das relações entre internos penitenciários e o perigo criminal: conceitos e preconceitos” (1997 a 1998), pesquisa financiada por Pibic/CNPq e orientada pelo Prof. Dr. Luís Carlos da Rocha, o qual me conduziu no caminho da investigação científica com forte objetividade e entusiasmo e: "Ateliê de pintura: criação e singularidade em atenção psicossocial” (1999), intervenção de estágio em saúde mental, orientada pelo Prof. Dr. Sílvio Yasui, o qual possibilitou-me refletir sobre a importância da ética e da valorização das diferentes singularidades humanas, ao longo do nosso existir.

Em 1998, realizei o estágio em Psicopedagogia e o curso de extensão universitária: “Introdução à psicologia da moralidade humana”, supervisionados pelo Prof. Dr. Nelson Pedro Silva, o qual desenvolvia, no momento, a sua tese de doutoramento. ${ }^{1}$ Nestas supervisões, surgia o meu interesse inicial pelo tema da fidelidade humana o qual era tratado sob a ótica de Jean Piaget, enquanto um valor moral.

Em 1999, realizei os estágios em Orientação Profissional, Psicoterapia Infantil e Terapia Familiar, amparados pelo referencial sistêmico e psicanalítico de modo que, ao mesmo tempo em que eu me interessava pela intervenção da clínica psicológica, pelos estudos da psicanálise, da dinâmica familiar e suas relações amorosas e de gêneros, pude

\footnotetext{
${ }^{1}$ SILVA, N. P. Entre o público e o privado: um estudo sobre a fidelidade à palavra empenhada. São Paulo, 2002. 353 p. Tese (Doutorado). Instituto de Psicologia da Universidade de São Paulo - USP, SP.
} 
refletir sobre o quão o tema da fidelidade amorosa marcava presença em minha prática profissional, quanto em minhas relações sociais.

Motivada pelo entusiasmo do principiante, flagrei-me em experiências tão diversificadas quanto significativas, seja na pesquisa, como na intervenção psicológica. Sem dúvida, os referenciais teóricos apreendidos, o contato com o saber e a postura de cada mestre, a escuta e o cuidado com o estar com o outro na prática piscológica, implicaram-se de forma construtiva em minha subjetividade e de forma expressiva em minha postura profissional, bem como criaram e mantiveram dúvidas e questionamentos em relação aos caminhos que eu devesse traçar no que se referia à pesquisa científica.

Em 2000, iniciei minhas atividades profissionais como psicóloga no “Centro de Educação Especial” da Associação de Atendimento Educacional Especializado, em Araraquara-SP, junto a crianças, jovens, adultos deficientes mentais e a uma equipe interdisciplinar de profissionais da área da Educação e da Saúde. Deparei-me com a vivência da sexualidade do deficiente mental e com uma grande dificuldade em conduzir meu trabalho no que dizia respeito a esta área, o que me trouxe inquietações e a necessidade de procurar orientação de profissionais especializados em Sexualidade. Surgia neste momento o interesse explícito pelas questões da sexualidade, pelo seu estudo e pela sua intervenção na prática profissional. Sexualidade! Área que adjacente à nossa existência passa a me envolver, neste momento, em meus interesses profissionais e intelectuais.

Uma trajetória de reflexões, que inicialmente me motivou para a busca da compreensão da fidelidade humana, se desfigurou em certo momento e se reconstruiu com outros vieses, pois a partir de minhas novas experiências profissionais pude pensar em especial na infidelidade amorosa e refletir sobre a sua íntima implicação no campo da Sexualidade, sobre a prevalência primordial das queixas afetivas e sexuais no âmbito clínico e sobre a banalização que este tema é tratado pelas relações quotidianas. Minha vontade e 
necessidade de elaborar um trabalho sobre a temática exposta se transformou pela ordem do desejo, para um imperativo ético.

Busquei um programa de pós-graduação que pudesse me auxiliar no desenvolvimento de um projeto de investigação, o Programa de Pós-Graduação em Psicologia, oferecido pelo Departamento de Psicologia e Educação da Faculdade de Filosofia, Ciências e Letras de Ribeirão Preto-USP, o qual oferece quatro linhas de pesquisa: (1) Fundamentos históricos e sócio-culturais da Psicologia; (2) Processos psicológicos e desenvolvimento humano; (3) Avaliação psicológica, intervenção educacional e promoção do desenvolvimento e (4) Promoção da saúde e ações da psicologia na comunidade. Dentre elas optei pela linha de pesquisa: Fundamentos históricos e sócioculturais da Psicologia, na qual se ancora a seguinte área de pesquisa: Sexualidade e reflexividade da moral sexual na constituição histórica-cultural do sujeito na pósmodernidade, cuja responsável é a Profa. Dra. Maria Alves de Toledo Bruns. Esta área de pesquisa se norteia pela reflexão e produção acadêmica acerca da temática da sexualidade utilizando a perspectiva ontológica e histórica-sócio-cultural e a metodologia de pesquisa qualitativa fenomenológica.

A construção de um projeto de pesquisa intitulado: "Desvelando a dor amorosa da infidelidade conjugal: discursos de homens e mulheres" viabilizou-se a partir de meu encontro com a Profa. Dra. Maria Alves de Toledo Bruns a qual me orientou. Nossas conversas iniciais sobre o fenômeno foram vivificadas por vários questionamentos: “o que significa a infidelidade amorosa na atualidade? que significados homens e mulheres atribuem a vivência da infidelidade amorosa do(da) parceiro(a)? como os gêneros a vivenciam num universo de transformações quanto às atribuições de papéis femininos e masculinos? que significado o juramento da fidelidade amorosa do(da) parceiro(a) perante a Lei Civil e a Igreja Católica assume para quem foi traído(a)? que casal é este que a 
vivencia? como homens e mulheres re-significam a relação afetiva e sexual do casal após vivenciaram a infidelidade do parceiro(a)? é possível reconstruir a relação amorosa?” Nosso foco de atenção se voltou para a compreensão do fenômeno que se apresenta da seguinte forma: Quais significados homens e mulheres atribuem à vivência da infidelidade amorosa do(a) parceiro(a) e como re-significam a relação amorosa após os(as) parceiros(as) lhes terem sido infiéis?

Essa questão central, que surge de nossas inquietações acadêmicas, se mostrou de grande importância e se justifica por ser capaz de possibilitar a ampliação da compreensão desse fenômeno entre os que trabalham com grupos familiares e lidam quotidianamente com a questão da infidelidade, seja em pesquisas, estudos ou atendimentos clínicos, como os profissionais da área da Psicologia, da Sexualidade, da Psicanálise, da Sociologia, da Educação, da Filosofia, da Fenomenologia. Além disso, a pesquisa aqui proposta poderá possibilitar contribuições significativas para a sociedade de modo geral, ao proporcionar reflexões sobre o modo como vêm ocorrendo as relações afetivas e sexuais, sobre as relações de gênero e sobre a própria educação sexual no momento atual.

Em fevereiro de 2003, fui aprovada pela seleção do Programa de Pós-Graduação em Psicologia da Faculdade de Filosofia, Ciências e Letras de Ribeirão Preto - USP e me tornei membro do Grupo de Pesquisa Sexualidade e Vida, que é ancorado a área de pesquisa: Sexualidade e reflexividade da moral sexual na constituição histórica-cultural do sujeito na pós-modernidade, e é cadastrado na Plataforma Lattes, do Centro Nacional de Pesquisa - CNPq. O Grupo de Pesquisa Sexualidade e Vida tem como objetivo a produção de investigações científicas e a divulgação para o público acadêmico e não acadêmico dos trabalhos desenvolvidos pelo grupo por meio de participações em eventos e publicações. Com a intenção de divulgar os trabalhos foi criada ainda uma home-page: www.sexualidade.psc.br, promovendo um intercâmbio cultural com outros centros 
nacionais e internacionais e como criação recente, foi lançado o Boletim Informativo, o qual encontra-se na elaboração do quarto número. Após a autorização do Comitê de Ética da Faculdade de Filosofia, Ciências e Letras de Ribeirão Preto -USP, para a realização de nossa investigação, iniciamos a revisão bibliográfica centrada nos seguintes eixos temáticos: a família, o casamento e o amor na sua trajetória sócio-histórica cultural; a infidelidade sob a perspectiva da Lei Civil, da Filosofia e da Psicologia Evolucionista; e a relação entre o amor, a dor psíquica e o luto, à luz de autores psicanalistas.

A fim de compreendermos o fenômeno em si, isto é, em sua “essência”, a qual só é obtida, em totalidade, na dimensão vivencial do sujeito pretendíamos entrevistar homens e mulheres casados, não entre si e que após seus(suas) parceiros(as) lhes terem sido infiéis tivessem permanecido unidos a eles(elas) em matrimônio. Entretanto, flagramo-nos, no momento de contatação dos colaboradores, com grandes dificuldades. O tema dessa investigação, tão habitual e naturalizado até então, mostrou-se velado. Algumas mulheres contatadas desistiram de nos conceder seus depoimentos no momento das entrevistas e os homens, se mantiveram inexpressivos por um longo período de tempo. Algumas pessoas receberam o tema com risos, outras com chistes, e outras então, com o silêncio ou com o desconhecimento. Em alguns momentos, questionamo-nos sobre a viabilidade científica de desenvolver essa investigação da forma como havíamos nos proposto. A possibilidade do fenômeno indagado alcançar visibilidade contrastou-se com “o não desejo de saber” de uma sociedade que mantém permissível a prática da infidelidade pelo homem e, por outro lado, considera inconcebível o infortúnio da experiência de dor e vergonha do ser masculino ser traído. Contudo, em meio aos “tropeços”, que serão descritos no capítulo da metodologia dessa investigação, obtivemos além das descrições femininas, as descrições masculinas, mas que, no entanto são descrições de homens que se separaram das esposas 
ou namoradas após vivenciarem a infidelidade amorosa destas e não de homens que continuaram unidos em matrimônio às esposas, como pretendíamos entrevistar no início.

Utilizamos o método fenomenológico descritivo proposto por Rezende (1990) e submetemos as descrições dos(das) colaboradores(as) aos momentos da análise, tais como descritos por Giorgi (1978) e Bruns (2003). Situamos o fenômeno em sua temporalidade e em sua construção sócio-histórica-cultural, pois o ethos da (in)fidelidade caminha em ressonância com a temporalidade do existir humano, envolvido pelo ethos social que se constrói pelos valores éticos e morais de cada tempo e espaço. Buscamos uma compreensão psicológica do fenômeno que co-existe com o ser humano, utilizando o referencial teórico da Psicanálise.

Falar de sexualidade nunca foi tarefa fácil, falar das tramas intersubjetivas, do amor e da dor também não é. Por isto, no decorrer desse trabalho muitas dúvidas pairaram entre aquilo que embora indizível e inexplicável que é o amor, a dor e a traição, é também escancarado e desvelado. Por isto recorremos, entre vários autores, ao psicanalista JuanDavid Nasio, que trabalha com a subjetividade de uma maneira muito coesa, dedicando estudos exclusivos ao tema da dor psíquica, abordando justamente o sentimento de luto e o processo de re-significação que ocorre após a vivência de uma dor psíquica, conceitos ricos para nós.

Tivemos que conduzir nossa investigação com persistência e respeito, com cautela e desprendimento, com a escuta compreensiva e com a postura sensível capaz de acolher o trágico que se configura para além da quebra súbita do equilíbrio narcísico para "o não desejo de saber”, ou “de falar”. Não desistimos de realizar nossa investigação frente às dificuldades encontradas, pois revelando o drama encontramos também a vida e nos reconhecemos enquanto sujeitos. 
Juntamente com a realização dessa investigação e com as atividades que realizo no “Centro de Educação Especial”, a minha trajetória profissional se marcou também pelo início de meu trabalho de docência no ano de 2005, junto ao Instituto Taquaritinguense de Ensino Superior “Dr. Aristides de Carvalho Schlobach” - ITES, em Taquaritinga-SP, no curso de graduação em Psicologia. Durante o de 2005, ministrei as disciplinas: Psicologia do Excepcional I, Psicologia do Excepcional II e Aconselhamento Psicológico II, além da atividade de supervisão de estágio em Psicologia do Excepcional.

Em setembro de 2005, ministrei juntamente com o Prof. Ms. Murilo da Silva Moscheta um mini-curso intitulado: “Conjugalidade: as relações afetivas e sexuais na sociedade atual" durante a "Semana Cultural do ITES", quando pude versar sobre a construção sócio-histórica-cultural da família ocidental, ao longo dos anos.

Nas experiências de estágio e de sala de aula, compartilhei com os alunos do $4^{0}$ ano de Psicologia do ITES, durante o ano de 2005, momentos de co-aprendizagem e de reflexões, construídos não somente pelos referenciais teóricos utilizados, mas pela mediação das vivências desses alunos nas APAEs de Taquaritinga-SP e Jaboticabal-SP. Foi a partir dessas experiências que eu e meus alunos apresentamos dois trabalhos, na modalidade Pôster de Comunicação Científica, durante o II Congresso Brasileiro de Educação Especial e II Encontro da Associação Brasileira de Pesquisadores em Educação Especial, promovidos pelo Programa de Pós-graduação em Educação Especial - PPGEEs da UFSCar e pela Associação Brasileira de Pesquisadores em Educação Especial ABPEE, realizados na Universidade Federal de São Carlos - São Carlos-SP, em novembro de 2005. Os trabalhos intitularam-se: "Brancas de Neves e Anões: da práxis psicopedagógica ao encontro e re-criação de subjetividades” e “Inclusão social e ateliês de singularidades: a utilização da arte como expressão e re-criação do sujeito”. 
Eu e a Profa. Dra. Maria Alves de Toledo Bruns, também apresentamos, durante o ano de 2005, nossos trabalhos em alguns eventos. Em abril apresentamos, na modalidade de Pôster de Comunicação Científica, o trabalho intitulado: “A infidelidade amorosa: discursos de mulheres à luz de Juan-David Nasio”, no I Simpósio Paraná - São Paulo de Sexualidade e Educação Sexual. Este foi promovido pelo Núcleo de Estudos da Sexualidade - NUSEX, do Programa de Pós-Graduação em Educação Escolar, pelo Centro de Pesquisas da Infância e da Adolescência: "Dante Moreira Leite e pelo Departamento de Psicologia da Educação da FCL - UNESP - Campus de Araraquara-SP; pelo Departamento de Psicologia Clínica da FCL -UNESP - Campus de Assis-SP; pelo Departamento de Psicologia Social e Institucional e Departamento de Ciências Sociais da UEL-Londrina-PR; pelo Centro Universitário de Maringá -PR- CESUMAR; pelo Grupo de Estudos: “Gênero, Sexualidade e Educação” - ANPED e pela Universidade Paulista -UNIP - Campus de Araraquara-SP; realizado nesta última. Em outubro de 2005, a Profa. Dra. Maria Alves de Toledo Bruns, participou do $2^{\circ}$ Encontro do Saber Psicanalítico do Sindicato dos Psicanalistas do Estado de São Paulo, realizado em São Paulo-SP, ministrando a seguinte palestra: “A infidelidade e as relações amorosas no momento atual”, a qual contou com a minha colaboração. Em novembro de 2005, re-apresentamos o trabalho intitulado: “A infidelidade amorosa: discursos de mulheres à luz de Juan-David Nasio” no VI Simpósio do CEFAS - Psicanálise, Grupalidade e Cultura, no CEFAS, em Campinas-SP. E, em dezembro de 2005, participei da mesa redonda intitulada: "Sexualidade da clínica à escola: debates e reflexões”, apresentando o trabalho intitulado: "Infidelidade: amor, dor e luto", na II Reunião Científica do Núcleo de Estudos da Sexualidade - NUSEX: "Sexualidade e educação: apontamentos para uma reflexão”, realizado na FCL - UNESP - Campus de Araraquara-SP.

Durante o presente ano, além de retomar junto ao curso de Psicologia do ITES as atividades de supervisão de estágio e as disciplinas ministradas durante o ano anterior, tem 
sido realizado, nesse primeiro semestre, o desenvolvimento de mais uma disciplina: Saúde Pública e Saúde Mental I.

Todos estes trabalhos acadêmicos puderam se viabilizar somente depois do meu ingresso no Programa de Pós-Graduação em Psicologia da Faculdade de Filosofia, Ciências e Letras de Ribeirão Preto-USP, o qual não me proporcionou somente a possibilidade de exercer o enriquecedor papel de pesquisadora e ampliar os meus horizontes enquanto psicóloga, mas também trouxe a satisfação de me tornar professora. É, pois, essa dissertação de mestrado a fonte geradora de toda essa trajetória.

Para essa investigação conseguir cumprir seu objetivo - compreender os significados atribuídos por homens e mulheres à vivência da infidelidade do(a) parceiro(a) e à vivência da re-significação de suas relações amorosas com os parceiros(as) após eles(elas) lhes terem sido infiéis - foi necessário construir um caminho que se explicita nos seguintes capítulos:

\section{CAPÍTULO 1: O AMOR, O CASAMENTO E A SEXUALIDADE.}

Nesse capítulo será apresentada a revisão da literatura referente ao estudo do contexto sócio-cultural contemporâneo e à história da família cristã, da qual somos herdeiros.

A revisão buscará discutir as relações entre as transformações sócio-culturais e tecnológicas e as questões da afetividade, da sexualidade, da família, do casamento e das relações entre os gêneros ao longo dos anos. Nossas ênfases se darão sobre as mudanças ocorridas no período histórico que chamamos de modernidade, as quais proporcionaram e ainda vêm proporcionando transformações abrangentes no campo familiar, conjugal e fora dele, nos trajetos de Eros. 


\section{CAPÍTULO 2. INFIDELIDADE: UMA LEI, UM PECADO, UM VALOR UM ESQUECIMENTO, UMA GUERRA DE ESPERMAS?}

Esse capítulo irá contextualizar a infidelidade amorosa na história da sociedade ocidental, baseada na cultura cristã, pois sua construção ocorre em consonância com os ethos sócio-culturais.

Serão apresentadas as compressões que a Religião Católica e a Lei Civil têm sobre a infidelidade amorosa, bem como observações advindas de alguns autores presentes no pensamento filosófico, psicológico e evolucionista.

\section{CAPÍTULO 3. TRAJETÓRIA METODOLÓGICA QUALITATIVA.}

Esse capítulo discorrerá sobre a metodologia de pesquisa qualitativa que se pauta na utilização do método fenomenológico descritivo, pois acreditamos que este nos oferece o melhor caminho em busca da compreensão do fenômeno discutido nessa investigação. As descrições dos(as) colaboradores(as) serão contextualizadas de modo sócio-cultural e submetidas ao referencial teórico da Psicanálise. Por este motivo, também será feita uma discussão acerca da possibilidade de utilizarmos a perspectiva fenomenológica enquanto método e a perspectiva psicanalítica enquanto referencial teórico interpretativo. Além disso, serão explicitadas as dificuldades encontradas no acesso aos(as) colaboradores(as) e a forma como foram obtidas as descrições, seguidas pelos respectivos perfis de cada um(uma) deles(delas).

\section{CAPÍTULO 4. O TEMPORALIZAR DA INFIDELIDADE AMOROSA PELAS VOZES FEMININAS E MASCULINAS.}

Tendo seguido os passos da análise tal como descritos pela metodologia fenomenológica descritiva, as descrições dos(das) colaboradores(as) foram categorizadas e subcategorizadas e serão apresentadas nesse capítulo. 
CAPÍTULO 5. PERPLEXIDADE, DOR E LUTO: A RE-SIGNFICAÇÃO DO AMOR E DA INFIDELIDADE VIVENCIADOS POR HOMENS E MULHERES.

Nesse capítulo será apresentada a reflexão sobre os significados que foram atribuídos por homens e mulheres à vivência da infidelidade amorosa do(a) parceiro(a), o que possibilitará ao leitor uma síntese compreensiva geral desses sentidos.

\section{HORIZONTES.}

Serão vislumbrados os horizontes que poderão ser percorridos a partir das múltiplas significações atribuídas à vivência da infidelidade amorosa do(a) parceiro(a) e da resignificação da relação afetiva e sexual do casal na atualidade. 


\title{
CAPÍTULO 1 - O AMOR, O CASAMENTO E A SEXUALIDADE
}

\begin{abstract}
“A imagem do mundo diariamente gerada pelas preocupações da vida atual é destituída da genuína ou suposta solidez e continuidade que costumavam ser a marca registrada das estruturas modernas. O sentimento dominante, agora, é a sensação de um novo tipo de incerteza, não limitada à própria sorte aos dons de uma pessoa, mas igualmente a respeito da futura configuração do mundo, a maneira correta de viver nele e os critérios pelos quais julgar os acertos e erros da maneira de viver. [...] Vivemos hoje, para tomar emprestada a feliz expressão cunhada por Marcus Doel e David Clarke, na atmosfera do medo ambiente”.
\end{abstract}

Zygmunt Bauman

\subsection{O cenário sócio-cultural atual e as transformações da modernidade}

No atual palco sócio-cultural, um processo acelerado de transformação social impulsionado principalmente por avanços tecnológicos vem derrubando fronteiras entre as nações, redefinindo práticas afetivas, exacerbando a individualidade e agravando o sentimento de insegurança. Vivemos a transição de regras, a ruptura de modelos solidificados, as transformações da sociedade de consumo, as mudanças notáveis da ética, o excesso de liberdade, a valorização do novo e do hedonismo, o sentimento de incerteza e a aceitação do efêmero, do fragmentário, do descontínuo e do caótico. Vivemos uma espécie de esvaziamento da existência quotidiana e a pulverização dos ideais de verdade. Presenciamos o constante paradoxo entre a exaltação do excesso e da moderação, entre o indivíduo mais autônomo e ao mesmo tempo mais frágil. Assistimos a um indivíduo que não sabe quem é e a uma sociedade que não sabe para onde ir. $\mathrm{O}$ universo parece estar desbussolado (Harvey, 1992; Bauman, 1998; Birman, 1999; Hall, 2002; Lipovetsky, 2004).

No palco familiar, não há uma representação social unívoca, definida e homogênea acerca do familiar e do conjugal, nem tão pouco acerca das concepções do feminino e do 
masculino que se inscrevem de maneira difusa, diversa, múltipla e efêmera. A extraordinária rapidez de mudança e de maleabilidade nas relações, evidenciando formas alternativas de vivenciar o casamento, remete-nos a uma realidade próxima e, contrariamente, a uma sensação de estarmos à deriva. Digerimos as mudanças tão vagarosamente que não sabemos ao certo qual o retrato de família que deve ser pintado, de modo que a percepção de um real fragmentado, descontínuo e diversificado coloca questões que desafiam o saber acumulado pelas teorias das Ciências Sociais.

De acordo com Hall (2002), o homem atual vive uma crise de identidade que compõe um processo amplo de mudança que estaria deslocando as estruturas sócioeconômica-culturais das sociedades modernas de modo que as paisagens culturais de classe, gênero, sexualidade, etnia, raça e nacionalidade são abaladas e com elas, os quadros de referência que davam aos indivíduos uma ancoragem estável do mundo social.

Esta mudança estrutural da sociedade estaria produzindo um sujeito com uma identidade móvel, em contínua e constante formação e transformação, de acordo com os sistemas culturais que nos envolvem.

Para HALL (2002, p.12-13):

O sujeito assume identidades diferentes em diferentes momentos, identidades que não são unificadas ao redor de um "eu” coerente. Dentro de nós há identidades contraditórias, empurrando em diferentes direções, de tal modo que nossas identificações estão sendo continuamente deslocadas. Se sentimos que temos uma identidade unificada desde o nascimento até a morte é apenas porque construímos uma cômoda estória sobre nós mesmos ou uma confortadora "narrativa do eu" (veja Hall, 1990). A identidade plenamente unificada, completa, segura e coerente é uma fantasia. Ao invés disso, à medida em que os sistemas de significação e representação cultural se multiplicam, somos confrontados por uma multiplicidade desconcertante e cambiante de identidades possíveis, com cada uma das quais poderíamos nos identificar - ao menos temporariamente. 
Dessa forma, o sujeito das Luzes, racional, dominador de sua história, científico e livre dos dogmas de outrora, com uma identidade fixa e estável é atualmente descentrado e o próprio processo de identificação, através do qual nos projetamos em identidades culturais, torna-se provisório, variável e problemático, produtor de identidades abertas, contraditórias, inacabadas e fragilizadas.

Desde o final do século XX, uma variedade de termos enfocando questões filosóficas e epistemológicas, tem sido sugerida para explicar a transição do moderno para o atual, entre outros: pós-modernidade, modernidade tardia, alta modernidade, sociedade pós-industrial, sociedade de informação e sociedade de consumo que, apesar de nos fornecer leituras diversas sobre a natureza do mundo pós-moderno, nos revela uma linguagem comum com as ênfases da descontinuidade, da fragmentação, da ruptura e do deslocamento (Giddens, 1991; Hall, 2002).

A noção de pós-modernidade surgida na França após a Segunda Guerra Mundial veio abalar os alicerces incontestáveis da racionalidade e alcançar o fracasso das grandes ideologias da história, nos inserindo num universo de eventos dos quais não compreendemos plenamente e que parecem, em grande parte, fora de nosso controle. Concedeu-nos o advento de uma temporalidade inédita da qual Lipovetsky (2004) chama de “a primazia do aqui-agora”.

Na perspectiva de Giddens (1991), as concepções usuais da pós-modernidade compreendem a transição corrente como decompondo a epistemologia. As tendências centrífugas das transformações sociais correntes e seu caráter de deslocamento são enfocadas. A contextualidade das reivindicações de verdade são afirmadas. O indivíduo é visto como dissolvido ou desmembrado pela fragmentação da experiência. Em face das tensões globalizantes, a falta de poder que os indivíduos sentem é teorizada. Desse modo, o esvaziamento da vida cotidiana é visto como o resultado da introdução dos sistemas 
abstratos e o engajamento político coordenado é impossibilitado pela primazia da contextualidade e da dispersão.

Ainda na visão deste autor, o sentido geral do termo pós-modernidade, entendido como um período de nítida disparidade do passado, tem outros significados:

\begin{abstract}
descobrimos que nada pode ser conhecido com alguma certeza, desde que todos os "fundamentos" preexistentes da epistemologia se revelaram sem credibilidade; que a "história" é destituída da teleologia e conseqüentemente nenhuma versão de "progresso" pode ser plausivelmente defendida; e que uma nova agenda social e política surgiu com a crescente proeminência de preocupações ecológicas e talvez de novos movimentos sociais em geral (GIDDENS, 1991, p.52).
\end{abstract}

Entretanto, voltando o olhar à natureza da modernidade, Giddens (1991) desafia as concepções usuais da pós-modernidade afirmando que essas concepções envolvem várias linhas diferentes que tiveram origem no pensamento pós-estruturalista. A ruptura com a aceitação de fundamentos, por exemplo, teria sido uma linha no pensamento filosófico originada entre os meados e o final do século XIX.

O autor compara essas concepções com uma posição alternativa que denomina de modernidade radicalizada, argumentando que os aspectos que distinguem as instituições no final do século XX expressam a emergência de um período de alta modernidade e que as mudanças correntes poderiam ser compreendidas então, como a modernidade vindo a entender a si mesma e não como a sua superação.

Esta visão enfatiza que a ruptura com as concepções providenciais da história, a dissolução da aceitação de fundamentos, o pensamento contra-factual orientado para o futuro e o esvaziamento do progresso pela mudança contínua são tão diferentes das perspectivas centrais do Iluminismo que chegam a justificar que ocorreram transições de longo alcance.

Nessa perspectiva, os modos de ação colocados pela modernidade nos libertaram de todos os tipos tradicionais de ordem social de uma maneira sem precedentes, tanto em 
extensionalidade quanto em intensionalidade, pois serviram para estabelecer formas de interconexão social que cobrem o globo e vieram a alterar algumas das mais íntimas e pessoais características de nossa existência quotidiana, como as relações dentro da família e da conjugalidade.

Entretanto, Giddens (1991) afirma que falar da pós-modernidade como suplantando a modernidade seria invocar aquilo mesmo que o termo declara impossível: dar alguma coerência à história e situar nosso lugar nela.

Desse modo, o ethos de modernidade radicalizada identifica os desenvolvimentos institucionais que criaram um sentimento de fragmentação e dispersão. O período denominado alta modernidade é visto como um conjunto de fragmentação em que a dispersão está dialeticamente vinculada as tendências para uma integração global e o eu é encarado como um processo ativo de auto-identidade. Esse paradigma ainda afirma que as características universais de verdade se impõem de maneira irresistível dada a primazia dos problemas de um tipo global e analisa a dialética da falta e da posse de poder em termos tanto da vivência como da ação. Encara a vida cotidiana como um complexo ativo de reações aos sistemas abstratos, envolvendo tanto apropriação como perda. Considera o engajamento político coordenado como possível e necessário, tanto no nível global como local. Define ainda a pós-modernidade, como transformações possíveis para além das instituições da modernidade, onde o universo pós-moderno estaria ainda a caminho.

Desse modo, estaríamos vivendo uma fase em que as conseqüências da modernidade estariam mais radicalizadas e universalizadas.

Hall (2002) ao analisar a obra de Giddens (1991), diz que a modernidade, longe de ser somente uma experiência de convivência com rápidas, abrangentes e contínuas mudanças é uma forma altamente reflexiva de vida à medida que as práticas sociais são examinadas e reformuladas à luz das informações recebidas sobre elas mesmas. 
Ainda na perspectiva de Hall (2002), o deslocamento do sujeito moderno seria resultado do impacto de cinco grandes avanços ou descentrações, isto é, o resultado de uma série de rupturas ou mudanças conceituais nos discursos do conhecimento moderno, ocorridas no pensamento na segunda metade do século XX, ou na modernidade tardia como denomina o autor. Tais mudanças conceituais teriam promovido o "descentramento" das identidades culturais e nacionais, ou seja, teriam tido efeitos desestabilizadores sobre as noções de sujeito, de conhecimento e da identidade da própria cultura e sociedade, sendo este processo afetado pelo fenômeno da globalização [o qual emergiu na Europa aproximadamente no século XVII, na modernidade].

Nessa visão, a globalização existe em seu interior com duas tendências contraditórias: a autonomia nacional e a própria globalização, as quais resultam em três possíveis conseqüências sobre as identidades culturais: (1) com o crescimento da homogeneização cultural e do pós-moderno global, as identidades nacionais estão se desintegrando; (2) as identidades nacionais e outras locais ou particularistas são reforçadas pela resistência à globalização e; (3) ao entrarem em declínio as identidades nacionais, novas identidades, híbridas, tomam seu lugar.

Os “descentramentos” analisados por Hall (2002) se referem:

(1) às tradições do pensamento marxista, que ao colocar as relações sociais os modos de produção, de exploração da força de trabalho e de circuitos do capital no centro de seu sistema teórico deslocaram duas posições-chave da filosofia moderna: que há uma essência universal de homem e que essa essência é o atributo de cada indivíduo singular, expulsando assim as categorias filosóficas do sujeito do empirismo, da essência ideal; 
(2) à descoberta do inconsciente por Sigmund Freud, teoria na qual a identidade, a sexualidade e a estrutura do desejo são vistas como em constante formação com base em processos psíquicos e simbólicos, em relação com os outros e através de processos inconscientes, idéia que refutou o conceito do sujeito cognoscente e racional de Descartes, provido de uma identidade fixa, unificada e estável;

(3) ao trabalho do lingüista estrutural Ferdinand de Saussure, que afirmou a instabilidade da identidade assim como a da linguagem pelo fato da língua ser um sistema social e não individual, preexistente a nós, de modo que ao falarmos uma língua, mais que expressarmos pensamentos interiores e originais, ativamos uma gama imensa de significados embutidos nos sistemas culturais. Desse modo, os significados das palavras surgem nas relações de similaridade e de diferença que umas têm com as outras no interior do código da língua e supõem um significado instável, suplementar, sem qualquer controle. Por isso, ao procurar o fechamento, o significado da fala é perturbado pela diferença e a identidade do falante se mantém instável;

(4) ao trabalho do filósofo e historiador Michel Foucault, que destacou um novo tipo de poder, o poder disciplinar, o qual preocupou-se em primeiro lugar com a regulação, sendo a vigilância o governo da espécie humana ou de populações inteiras e, em segundo lugar, com o indivíduo e com o corpo, através de instituições que policiaram e disciplinaram as atividades, o trabalho, a saúde física e moral as práticas sociais e da vida familiar das populações modernas. O caráter dos regimes disciplinares, suas técnicas de aplicação do poder e do saber acabou por individualizar ainda mais o sujeito e envolver mais intensamente o seu corpo. Quanto mais coletivas e organizadas a natureza das instituições da 
modernidade tardia, maior o isolamento, a vigilância e a individualização do sujeito;

(5) ao impacto do feminismo tanto como crítica teórica quanto como um movimento social. O feminismo, junto com outros movimentos sociais: os movimentos estudantis, juvenis contraculturais e antibelicistas, as lutas pelos direitos civis, os movimentos revolucionários do Terceiro Mundo e os movimentos pela paz, tiveram uma ênfase cultural muito forte. Estes movimentos suspeitaram de todas as formas burocráticas de organização, favoreceram a espontaneidade e os atos de vontade política refletindo o enfraquecimento da classe política e das organizações políticas de massa com elas associadas, bem como suas fragmentações em separados movimentos sociais, instituindo a política de identidade, isto é, uma identidade para cada movimento. O feminismo teve também uma relação direta com o “descentramento” conceitual do “sujeito cartesiano e sociológico”, pois ao questionar a clássica distinção entre o privado e público politizou a subjetividade, a identidade e o processo de identificação enfatizando a produção de sujeitos generalizados e abrindo para a contestação política arenas inteiramente novas da vida social: a família, a sexualidade, a divisão do trabalho doméstico, o cuidado com as crianças, etc. Contudo, ao questionar que homens e mulheres eram parte da mesma identidade, a humanidade, o feminismo incluiu a formação de identidades sexuais e de gênero.

Nessa trajetória de apreender as transições em pauta, Lipovestky (2004) corrobora com a idéia de Giddens (1991) ao defender que, desde os anos 50 o mundo estaria vivendo uma intensificação jamais vista do tripé que caracteriza o mundo moderno: o mercado, o indivíduo e a evolução técnico-científica. 
Concorda com a idéia de que a modernidade ocasionou uma ruptura essencial na história da humanidade com as conquistas da ciência e que teria feito do futuro, por intermédio da razão, o locus da felicidade vindoura e o fim dos sofrimentos.

Para o autor, o passado e o futuro tornaram-se desacreditados quando o otimismo da “filosofia das Luzes” e do “cientismo” do século XIX, deixaram de ser correntes, sobressaindo-se uma tendência a se pensar o presente como a referência essencial dos indivíduos.

A pós-modernidade representou o momento histórico em que todos os freios institucionais opostos à emancipação individual deram lugar à manifestação dos desejos subjetivos, da realização individual e do amor-próprio. As grandes estruturas socializantes perderam a autoridade, as grandes ideologias a expressão, os projetos históricos, a mobilidade e o âmbito social se tornaram o prolongamento do privado. Enquanto na modernidade as identidades eram organizadas verticalmente onde a família, a empresa e a política tendiam a um ponto superior comum, com o avanço crescente da globalização, o laço social se horizontalizou e os ideais se pulverizaram.

[...] ao permitir uma libertação dos indivíduos em face do mundo a que pertencem, uma autonomização que permitiu a cada um não mais seguir um caminho preestabelecido pela tradição e assumir uma liberdade de ação cada vez mais acentuada, a pós-modernidade possibilitou realizar aqueles ideais das Luzes que a modernidade anunciara em termos meramente legalísticos, sem ter-lhes dado força real (LIPOVETSKY, 2004, p. 20).

Entretanto, Lipovetsky (2004) vai além das concepções de pós-modernidade ou modernidade tardia e, enfatizando o avanço grotesco da globalização e das novas tecnologias de comunicação junto ao disparate do consumismo a partir dos anos 80, se refere a uma sociedade pós-disciplinar e nos oferece uma concepção mais recente sobre as transformações sócio-culturais vigentes, a hipermodernidade ou "era do vazio”, a qual, para esse autor, tem como conceito central a “personalização”. 
Essa perspectiva considera a ação da igualdade, do modernismo na arte e do advento da psicanálise, fatores importantes para as transformações da modernidade, mas afirma o consumo de massa e os valores que ele veicula de cultura hedonista e psicologista, como os principais responsáveis pelas transformações em curso.

Nessa visão, a moda e o consumismo contribuíram para a ampliação da esfera da autonomia subjetiva e das diferenças individuais, para o esvaziamento dos princípios sociais reguladores e para a dissolução das unidades de opiniões e dos modos de vida sendo que, através do “mundo midiático" teríamos nos inserido no registro do espetacular, do superficial, da sedução e do entretenimento.

A renovação de formas, a inconstância da aparência, a sedução e a diferenciação marginal presentes na moda afirmaram a soberania e a autonomia humana sobre o mundo natural e estético, num momento em que a sociedade burocrática e democrática se apresentou como superficial e frívola, impondo a normatividade não mais pela disciplina, mas pela escolha e pela espetacularidade.

Neste contexto, assistimos a desqualificação do passado e a valorização do novo, a afirmação do individual sobre o coletivo em virtude da subjetivação do gosto, da primazia e do efêmero e da economia da liberdade individual.

Na ótica de Debord (1997), em 1969 teria surgido a “teoria do espetáculo” com a “negação da vida que se tornou visível”, com a “perda da qualidade” ligada à formamercadoria, e com a “proletarização do mundo”.

Nas sociedades em que reinam as modernas condições de produção, a vida se apresenta como uma imensa acumulação de espetáculos, os quais não são representados por um conjunto de imagens, mas por uma relação social entre as pessoas, que é mediada por imagens, de modo que faz a vida tornar-se uma representação. 
O "espetáculo" se apresenta como projeto e resultado do modo de produção existente, o modelo atual da vida dominante, a afirmação onipresente da escolha, já feita na produção, bem como o consumo decorrente dessa escolha. Ele é “o âmago do irrealismo da sociedade real” (DEBORD, 1997, p. 13). A realidade surge "no espetáculo real” e este surge como inversão concreta da vida, como movimento autônomo do não-vivo. Essa alienação recíproca constitui, segundo esta perspectiva, a essência e a base de nossa sociedade. O “espetáculo” é o sentido da prática total de uma formação econômica e social, o seu emprego do tempo, o momento histórico que nos contêm.

O conceito de espetáculo unifica e explica uma grande diversidade de fenômenos aparentes. Suas diversidades e contratastes são as aparências dessa aparência organizada socialmente, que deve ser reconhecida em sua verdade geral. Considerado de acordo com seus próprios termos, o espetáculo é a afirmação da aparência e a afirmação de toda vida humana - isto é, social - como simples aparência. Mas a crítica que atinge a verdade do espetáculo o descobre como a negação visível da vida; como negação da vida que se tornou visível (DEBORD, 1997, p.16, grifo nosso).

Neste palco, o espetáculo “domina os homens vivos quando a economia já os dominou totalmente” (DEBORD, 1997, p.16).

O espetáculo não deseja chegar em nada que não seja ele mesmo e acaba por ser a economia se desenvolvendo por si mesma, num sistema em que o fim não é nada, mas o desenrolar é tudo. Os objetos produzidos nessa sociedade demonstram a racionalidade do sistema e o avanço econômico crescente que molda uma multidão crescente de imagensobjetos.

O espetáculo se faz, assim, a principal produção da sociedade atual.

Para Debord (1997, p. 18):

A primeira fase da dominação da economia sobre a vida social acarretou, no modo de definir toda realização humana, uma evidente degradação do ser para o ter. A fase atual, em que a vida social está totalmente tomada pelos resultados acumulados da economia, leva a um deslizamento generalizado do ter para o parecer, do qual todo "ter" efetivo deve extrair seu prestígio imediato e sua função última. Ao mesmo tempo, toda realidade individual tornou-se social, diretamente dependente da força 
social, moldada por ela. Só lhe é permitido aparecer naquilo que ela não é.

O “espetáculo” é, ainda, uma tendência a fazer ver o mundo, feita por diferentes mediações especializadas.

A especialização do poder, a mais velha especialização social, encontra-se paradoxalmente, na visão de Debord (1997), na raiz do “espetáculo”. Desse modo, o “espetáculo” é a representação diplomática da sociedade hierárquica diante de si mesma, na qual toda outra e qualquer fala é banida, de modo que o mais moderno é também, o mais arcaico.

Para Debord (1997, p. 20) o “espetáculo” é, então:

o discurso ininterrupto que a ordem atual faz a respeito de si mesmo, seu monólogo laudatório. É o auto-retrato do poder na época de sua gestão totalitária das condições de existência. A aparência fetichista de pura objetividade nas relações espetaculares esconde o seu caráter de relação entre homens e entre classes: parece que uma segunda natureza domina, com leis fatais, o meio em que vivemos. Mas o espetáculo não é o produto necessário do desenvolvimento técnico, visto como desenvolvimento natural. Ao contrário, a sociedade do espetáculo é a forma que escolhe seu próprio conteúdo técnico. Se o espetáculo, tomado sob o aspecto restrito dos "meios de comunicação de massa", que são sua manifestação superficial mais esmagadora, dá a impressão de invadir a sociedade como simples instrumentação, tal instrumentação nada tem de neutra: ela convém ao automovimento total da sociedade. Se as necessidades sociais da época na qual se desenvolvem essas técnicas só podem encontrar satisfação com sua mediação, se a administração dessa sociedade e qualquer contato entre homens só se podem exercer por intermédio dessa força de comunicação instantânea, é porque essa "comunicação" é essencialmente unilateral; sua concentração equivale a acumular nas mãos da administração do sistema os meios que lhe permitem prosseguir nessa precisa administração.

A separação, isto é, a divisão social do trabalho e a formação de classes imperam na sociedade do espetáculo de modo que, a separação generalizada entre o trabalhador e o que ele produz, faz perder o ponto de vista unitário sobre a atividade realizada e a comunicação pessoal direta entre os produtores. Com o progresso da acumulação dos produtos separados, e da concentração do processo produtivo, a unidade e a comunicação tornam-se atributos exclusivos da direção do sistema e, como conseqüência, proletariza o mundo. O 
trabalhador produz uma força independente de si, na qual o sucesso por essa produção, volta-se para o produtor como uma “despossessão”.

Esta ótica considera que, com a acumulação de seus produtos alienados, o tempo e o espaço de seu mundo se tornam estranhos para o trabalhador, sendo o espetáculo, o mapa desse novo mundo, correspondente a fabricação concreta da alienação.

Assim, a elevação econômica se torna a expansão dessa produção industrial específica, a alienação, a qual já fazia parte do núcleo inicial da economia. "O homem separado de seu produto produz, com cada vez mais força, todos os detalhes de seu mundo. Assim, vê-se cada vez mais separado de seu mundo. Quanto mais sua vida se torna seu produto, tanto mais ele se separa da vida” (DEBORD, 1997, p. 25).

Fundamentando sua “teoria do espetáculo” no sistema econômico, Debord (1997) afirma ainda que todos os bens selecionados pelo sistema espetacular são também as suas armas para o reforço constante das condições de isolamento das multidões solitárias. Diz que o isolamento é a produção circular do sistema econômico e conclui que, o espetáculo é “o capital em tal grau de acumulação que se torna imagem” (DEBORD, 1997, p.25).

Bucci e Kehl (2004, p.16) também vêm corroborarem com a "teoria do espetáculo”:

Vivemos uma era em que tudo ocorre para a imagem, para a visibilidade e para a composição de sentidos no plano do olhar. [...] a comunicação e mesmo a linguagem passam a necessitar do suporte das imagens num grau que não se registrou em outro período histórico. Os mitos, hoje, são muito olhados. São pura videologia.

Segundo estes autores, a palavra “videologia” corresponde à junção entre o mito ${ }^{2}$ e a ideologia e pode ser entendida como a "análise e interpretação do visível no imaginário contemporâneo”.

\footnotetext{
${ }^{2}$ No sentido literal, um mito é um relato fabuloso de caráter sagrado concernente a seres que personificam os agentes naturais ou as origens de uma sociedade, servindo de referência justificadora ou de modelo. Em sentido mais amplo, o mito é uma representação coletiva elaborado a propósito do comportamento atribuído a determinados grupos sociais. E do ponto de vista sociológico, o mito é uma representação coletiva meio irracional e de forte valor afetivo (Durozoi \& Roussel, 1993).
} 
Esta perspectiva afirma que, o sistema de signos que compõe o imaginário das sociedades industrializadas, é re-trabalhado pelos meios de comunicação de massa, tais como os cinemas, os jornais, as revistas, os outdoors e a televisão, sendo esta última, acima de todas as mídias, a grande produtora de mitos, pois mais que dar a palavra inicial e a última palavra sobre qualquer assunto, a TV dá a primeira e última imagem sobre todos os assuntos.

De acordo com Bucci e Kehl (2004, p. 18):

[...] o mito necessariamente cimenta as estruturas de qualquer sociedade, pois fornece um suporte imaginário ao desamparo dos sujeitos na linguagem. No sistema de mitos próprio de cada cultura, o homem está "em casa". O mito oferece um conjunto de conceitos indiscutíveis, de pouca ou nenhuma ambigüidade, compartilhado por todos os membros de um grupo, de modo a produzir, se não uma verdade, ao menos aquilo que Gustave Falubert ${ }^{3}$ chamava "effect du réel”.

Retomando Debord (1997), este afirma a atualização da alienação do trabalho pela economia vigente. Retomando Lipovetsky (2004), este também considera que alguns valores e sentimentos próprios da modernidade teriam escapado a esfera do "hiperconsumismo", como é o caso do amor, da preocupação com os direitos humanos e com a verdade, do gosto pelo voluntariado e pela indignação. E com a leitura de Bucci e Kehl (2004), somos levados a crer na permanência ou na atualização dos mitos, em nossa sociedade atual.

Somos inseridos num universo paradoxal, no qual enquanto alguns valores são fragmentados e esmagados, outros são conservados e/ou atualizados, sendo as idéias, muitas vezes, guerreiras umas das outras.

Ao discorrer sobre a “era do vazio", Lipovetsky (2004) afirma sobre as conseqüências que os processos empreendidos pela sociedade do consumo têm na construção do homem contemporâneo. Vê a “era do vazio” como um período fruto de um

\footnotetext{
${ }^{3} \mathrm{O}$ escritor realista Gustave Flaubert percebeu na segunda metade do século XIX que, a operação que articulava os artifícios do uso da língua era acomodada à uma nova classe dominante, de modo que o real pode ser compreendido como um efeito do uso da palavra (BUCCI \& KEHL, 2004).
} 
homem angustiado e receoso frente à liberdade de escolha que a pós-modernidade lhe ofereceu. Desse modo, a hipermodernidade define o constante paradoxo entre a cultura do excesso e da ausência ou moderação, na qual a autonomia coexiste com a dependência; a bulimia com o autocontrole; o individualismo com a desagregação das estruturas tradicionais de normatização; o empenho prometéico com a falta de vontade; a responsabilidade com o desregramento; e o gozo com a angústia.

O indivíduo contemporâneo, ao mesmo tempo em que se tornou mais autônomo e mais livre, é mais instável e mais frágil na medida em que suas obrigações e exigências tornam-se mais amplas. Tornou-se um Narciso ${ }^{4}$ inseguro, ansioso, exibicionista e autocentrado capaz de buscar prazer a qualquer custo, ao mesmo tempo em que vivencia uma espécie de esvaziamento das relações inter-humanas, experimenta a depressão, a solidão, o auto-abandono, o estresse e a desestruturação, num momento em que não consegue atender aos apelos e às imposições surgidas pelo mundo globalizado.

Dizem que no universo da pressa, o vínculo humano é substituído pela rapidez; a qualidade de vida, pela eficiência; a fruição livre de normas e de cobranças, pelo frenesi. Foram-se a ociosidade, a contemplação, o relaxamento voluptuoso: o que importa é a auto-superação, a vida em fluxo nervoso, os prazeres abstratos da onipotência proporcionados pelas intensidades aceleradas. Enquanto as relações reais de proximidade cedem lugar aos intercâmbios virtuais, organiza-se uma cultura de hiperatividade caracteriza pela busca de mais desempenho, sem concretude e sem sensorialidade, pouco a pouco dando cabo dos fins hedonistas (LIPOVETSKY, 2004, p. 80-81).

Com a liberação dos costumes e a lógica paradoxal, os quadros estáveis referentes às relações no casamento, na família e entre os gêneros, tornando os vínculos entre as pessoas mais complicados que no passado, quando a norma tradicional impunha a cada um seu devido lugar na ordem social.

\footnotetext{
${ }^{4}$ Narciso é aquele que, "fascinado por seu rosto, quis pegar seu reflexo na água e pereceu afogado" (DUROZOI \& ROUSSEL, 1993, p. 336) e narcisismo é o "amor que o sujeito atribui a um objeto muito particular: a si mesmo” (CHEMANA, 1995, p. 139).
} 
Desse modo, à medida que a identidade da cultura e do indivíduo foi descentrada pelo poder global, as relações na família, na conjugalidade e fora destas instituições foram afetadas, sendo reconstruídas de acordo com a lógica sócio-cultural vigente.

Com base nos autores apresentados neste capítulo, flagramo-nos no universo da personalização, da afirmação presente da escolha e, ao mesmo tempo, da alienação; da era que junta o mito à ideologia; que vive da aparência e da superficialidade e, ao mesmo tempo, que atualiza sentimentos próprios da modernidade. Que universo é este? Como as relações afetivas e sexuais são vivenciadas neste universo? Investigar sobre a infidelidade amorosa na atualidade requer conhecer o cenário sócio-cultural no qual ela se acalenta. Mas a fim de responder a essas questões, temos que necessariamente recorrer à historia da família ocidental.

Giddens (1991), nos lembra que, as grandes transformações dramáticas e abrangentes durante os quatro últimos séculos, são significativas para a compreensão da existência humana atual. As transformações sócio-culturais e tecnológicas ocorridas a partir da modernidade resultaram em conseqüências marcantes nos modos de relações afetivas e sexuais na atualidade. Inicialmente, essas transformações resultaram na divisão entre a sociedade e a família em “mundo público e privado” e conseqüentemente, na padronização de papéis sociais e sexuais para os homens e para as mulheres; e depois, elas incitaram a ocorrência da heterogeneidade de relações no que se refere à afetividade, à sexualidade, à conjugalidade e à família, tornando as relações entre os gêneros mais democráticas e exacerbando a individualidade, entre outras mudanças, as quais veremos nos sub-capítulos posteriores.

Contudo, a fim de compreendermos as conseqüências para a família e para a conjugalidade, advindas com as ocorrências na modernidade, precisamos, ainda, ir além 
destes períodos e conhecer como foram as relações na família e no casamento de nossa sociedade em suas origens, o que faremos no sub-capítulo a seguir.

\subsection{A Igreja, o casamento e o amor: um confronto, um desencontro, um enlace.}

"Que cada homem tenha uma mulher, e cada mulher, um homem. Melhor seria que ficassem castos, mas se não podem se conter, casem-se. É melhor casar do que arder”.

São Paulo - I Cor., VII, 1

Segundo as análises de Levi-Strauss (1980) sobre as sociedades arcaicas da Europa ocidental e oriental, a aliança entre comunidades diferentes teria sido o fator determinante na origem do casamento.

Assim, o casamento se constituiu por intermédio das relações exogâmicas e do arquétipo da troca [o qual parece permear nossas expectativas em torno das relações afetivas e sexuais até os dias de hoje].

A exogamia tem como regra fundamental e imutável, a manutenção da existência do grupo enquanto grupo, o que o leva a realizar a troca de bens considerados escassos e imprescindíveis para sua comunidade, como também a troca de mulheres. Num esforço constante de coesão e de solidariedade, além de instalar a reciprocidade de direitos e deveres entre os grupos sociais e de ligar os homens entre si, sobrepondo os laços artificiais aos laços naturais de parentesco, a exogamia se constitui também como um meio de evitar o fracionamento e a divisão indefinida do grupo, como um meio de evitar a guerra e como um meio de aliar tropas.

Este tipo de relação exprimiu um valor social capaz de assegurar o domínio cultural sobre o natural e o domínio social sobre o biológico ao instalar a proibição do incesto, uma 
regra tão universal quanto a linguagem que, antes de significar a proibição de alguém se casar com a mãe, com a irmã ou com filha de outrem, imprime a obrigação de alguém dar a outrem a mãe, a irmã e/ou a filha, assegurando a troca.

Entretanto, conservando-se a "lei do incesto", as regras do casamento se modificaram ao longo dos anos, sendo variadas de um lugar ou de uma sociedade a outra.

De acordo com a Sagrada Escritura, o século XIII a.C. é conhecido através de quatro livros que, juntamente com o Gêneses, formam o Pentateuco: o Êxodo, o Levítico, os Números e o Deuteronômio, e neles estão compilados os documentos escritos sobre o tempo de Moisés.

Moisés foi designado a conduzir o povo hebreu para fora do Egito e para realizar sua unidade política e religiosa elaborando uma primeira legislação a qual procurou colocar em prática os ensinamentos de Decálogo [Os dez mandamentos]. Este era inspirado nas legislações sociais dos semi-nômades e nas instituições madianitas mais avançadas, e exprimia as exigências fundamentais de Deus.

Moisés se tornou o libertador e legislador do povo de Israel, bem como o mediador entre o povo e Deus e constituiu sob um forte sentimento de justiça, fundado na prática das virtudes morais e num verdadeiro amor fraternal o "Código da Aliança”.

O Decálogo, o qual encontramos no Livro do Êxodo: 20 e é repetido em Deuteronômio 5:1-21, é a aliança de Deus com Israel, uma demonstração do comportamento que Deus requer de todo ser humano em relação à Ele e ao seu semelhante.

As palavras do Decálogo foram dadas por Deus e, portanto, se constituíram pela expressão de Sua vontade. A Sua ética é a ética divina e deve guiar o comportamento do homem que se diz servo do Senhor. Cinco de seus mandamentos tem por objetivo unicamente Deus e o seu culto e os outros cinco, visam salvaguardar os direitos do próximo e impedir todo e qualquer desejo interior que seja maligno. 
Desse modo, é no $7^{\circ}$ e $10^{\circ}$ Mandamento que encontramos a proibição do adultério e da cobiça: “não adulterás” e “não cobiçarás a casa do teu próximo, a mulher do teu próximo, nem o seu servo, nem a sua serva, nem o seu boi, nem o seu jumento, nem coisa alguma de teu próximo”.

Jesus Cristo, ao pronunciar o Sermão do Monte expondo a sua doutrina (Mt. 5-7) reafirmou a ética estabelecida no Monte Sinai por Moíses, confirmando o teor dos Dez Mandamentos, bem como a progressiva revelação de Deus aos homens, a qual encontra em Cristo o seu máximo esplendor. Jesus Cristo sintetizou a Lei Cristã em apenas Dois Mandamentos: “Amar a Deus sobre todas as coisas” e “Amar ao próximo como a ti mesmo” (Mc. 12:28-34).

Posto que Deus não muda e nem Nele há variação, os princípios éticos desta revelação, a dos Dez Mandamentos são perenes e imutáveis e constituem a ética Cristã.

Assim, o casamento cristão em todo o tempo e lugar mantém o juramento da fidelidade ao cônjuge, no ato matrimonial.

No século I a.C. o Imperador Romano Augusto fez recair sobre as mulheres o rigor das penalidades do ato do adultério. A mulher adúltera era banida, perdia o direito sobre a metade do dote esponsalístico e de um terço de todos os outros bens que ela possuísse. Caso o marido não se divorciasse dela, ele poderia ser processado e seu amante, caso fosse casado, também era banido, mas se fosse solteiro, estava livre de punições (Pittman, 1994 apud Zampieri, 2004).

De acordo com Pittman (1994 apud Zampieri, 2004), a adoção da monogamia teria se concretizado, entretanto, somente com a independência entre o cristianismo e o judaísmo, o que afetou o costume dos judeus que viviam na Europa cristã. Estes passaram a aceitar a monogamia como obrigatória seguindo a proibição da poligamia, feita pelo rabino Gershon Bem Judah no ano de 1030 d.C. 
Contudo, os judeus que viviam no mundo muçulmano, em que a poligamia é aceita, preservaram o antigo costume, seguindo apenas a proibição talmúdica de não ter mais de quatro mulheres de uma vez só.

Enquanto o Decálogo teve origem antes do cristianismo e nele se inscreveu a proibição do adultério, o casamento e a celebração das núpcias no ocidente cristão foi até o século V. d.C., de acordo com Vainfas (1986), um ato privado ocorrido entre os nobres, sob o cuidado dos pais, e sem a interferência do clero.

O casamento não era universal, nem indissolúvel e o exercício da sexualidade não se conjugava a ele, nem se pautava pela noção de pecado. O casamento era um "negócio de família” mantido de acordo com os interesses da linhagem e não direcionado para o prazer individual. Era constituído pela promessa, pelo pacto conjugal e pelo estabelecimento do dote esponsalístico, sendo o responsável pela transmissão do nome, da herança, de títulos e de organização de sistemas de alianças políticas. Neste contexto, a linhagem abrangia um vasto grupo de pessoas em relações hierárquicas, fixas e bem delimitadas sob a autoridade do pater famílias, o detentor das normas e leis da sociedade.

Os ideais cristãos tiveram uma grande importância e influência sobre as regras estabelecidas no casamento e na família, nas sociedades ocidentais. Mas no início do cristianismo, parcelas da Igreja, no entanto, se dividiram entre aceitar e condenar o casamento, pois os ideais cristãos valorizavam a ascese pregando a castidade, a virgindade e a continência (Vainfas, 1986).

Com a queda do Império Romano, a partir do século $\mathrm{V}$ se abriu caminho para a tentativa de submissão de reis e cavaleiros ao domínio da Igreja Católica e, conseqüentemente, para o exercício de suas normas sobre o casamento. Os papas assumiram o poder político de quase toda a Europa Ocidental, o modelo de “Sagrada Família” foi instituído e o casamento, aprovado pela Igreja Católica, tornou-se uma forma de disciplinar 
a sexualidade: uma concessão para refrear os libertinos, os “desejos da carne” que se vinculavam ao pecado.

Mas os pensamentos e as regras da Igreja Católica referentes ao casamento teriam começado realmente a alcançar soberania apenas na Idade Média quando o casamento foi instituído como sacramento, no século XII e, tornado monogâmico e indissolúvel, no século XIII, sendo regido por normas de comportamento sexual.

A partir de então, o ato matrimonial passou a ser conduzido por um padre e a sexualidade encontrou lugar legítimo dentro do casamento, com o objetivo exclusivo da procriação.

O casamento fundamentou-se por uma teologia sexual fundada em três eixos principais: (1) a imposição da relação carnal, sob uma dívida no casamento; (2) a condenação de qualquer ardor na relação carnal entre os cônjuges; e (3) a classificação dos atos permitidos e proibidos na relação carnal, tendo em vista à procriação.

Ao permitir o controle da Igreja em relação às alianças da nobreza e, sobretudo da realeza, o controle eclesiástico impôs modificações profundas no casamento, principalmente às mulheres: a fecundidade tornou-se indispensável ao casamento, a esterilidade abominada e a fidelidade feminina exigida. Esta última fora exigida também ao primogênito, o responsável de perpetuar a linhagem e transmitir a herança e o poder. Entretanto, era permitida ao primogênito a satisfação da voluptas com a prática de certas uniões temporárias chamadas de friedelehe, nas quais os jovens pagavam aos pais das moças pela virgindade das filhas.

A monogamia, garantia a fidelidade feminina e a legitimidade dos filhos e a indissolubilidade do casamento, garantia a condição de estabilidade matrimonial e da comunidade. A bigamia era punida com a excomunhão, com o abandono ou até mesmo com a morte da esposa transgressora. 
Além da exigência da fidelidade e da virgindade feminina até o casamento, outras regras sexuais foram impostas pela Igreja Católica como: a abstinência sexual nos dias santos, ao longo da gravidez e nos períodos pós-parto e pós-mestrual; e a proibição dos métodos contraceptivos e do sexo antes e fora do casamento [as quais são infrações condenadas até hoje pela Igreja].

A Igreja Católica instalou também o exercício da confissão, incitou a obediência feminina ao pai e a lealdade ao marido, incentivou o aumento da prole numerosa, além de se responsabilizar também pelos casamentos, pelos nascimentos e pelos óbitos.

Com a ação combinada entre a Igreja Católica e a Monarquia Absoluta, os ideais cristãos foram lentamente incorporados pela sociedade e exerceram o papel de controlar os comportamentos sexuais antes, dentro e fora do casamento.

Sendo os objetivos do casamento formar alianças, como um contrato comercial, sob obrigações e dívidas e servir à procriação, o casamento da época nada tinha a ver com o amor, ou melhor, o amor era vivido de formas diferentes dentro e fora do casamento: o amor discernimento para a união conjugal e o amor cortês para as relações ilícitas.

Na perspectiva do poeta e historiador Paz (2001), a Igreja Católica teria incentivado, em seu início, a nítida distinção entre o sentimento amoroso e o casamento. Afinal, amar uma criatura com o amor o qual devesse ser professado ao Criador era uma idolatria e uma confusão entre o terrestre e o divino, o temporal e o eterno.

O estudo de Paz (2001) referente à história da idéia de amor no ocidente e no oriente, nos oferece subsídios para compreender as divergências que a Igreja Católica enfrentou no início, ao impor suas regras sobre a sociedade ocidental e, em especial, sobre o casamento.

Nessa visão, o amor ou sentimento amoroso teria sempre existido, seja no ocidente como no oriente, sendo a vasta literatura sobre o tema como: o conto de Eros e Psique, os poemas de Safo, as canções de Shih Ching, o mito de Tristão e Isolda, os romances 
espanhóis e tantas outras histórias [sem falarmos dos conteúdos veiculados pela mídia contemporânea], provas da evidência da existência e da universalidade do amor em todo o tempo e lugar.

Nessa perspectiva, o amor em sua forma mais simples e imediata não é senão a atração passional que sentimos por uma outra pessoa entre muitas outras, ou seja, a transformação do objeto erótico em um indivíduo livre e único. O amor se refere ainda a uma atração mútua e carregada de esforços e dificuldades a serem enfrentados para nos unir ao amado. A atração imediata pelo outro, apesar de involuntária é ainda a realização de uma escolha, de modo que o destino e a liberdade, o objetivo e o subjetivo, o corpo e a alma, a predestinação e a escolha se cruzam no amor.

No entanto, a filosofia ou idéia de amor se difere do sentimento amoroso. A primeira é capaz de brotar somente onde existam circunstancias sociais, intelectuais e morais para isto.

Desse modo, a filosofia do amor teria nascido na Grécia, quando Platão sistematizou a idéia de alma, já presente em alguns pré-socráticos como Pitágoras e Empédocles. O ethos platônico desnaturalizou o amor e o transformou num erotismo filosófico e contemplativo do qual excluiu a mulher. A presença da alma e a busca da imortalidade em uma história de amor é um eco platônico, no qual o mito andrógeno se tornara uma realidade psicológica: “todos nós buscamos a nossa metade perdida”. Ainda na visão platônica, a alma imortal, prisioneira de um corpo mortal volta ao empíreo após a morte física, enquanto o corpo volta a ser matéria informe. Sem o ethos platônico, a nossa filosofia do amor poderia ter tido uma formulação muito diferente e difícil de imaginar da qual a temos.

A perspectiva de Paz (2001) considera ainda que, a severa condenação do prazer físico e a pregação da castidade como caminho para a virtude e a beatitude no Cristianismo podem ter sido influenciadas pela separação platônica entre o corpo e a alma. 
Mas ao contrário da doutrina platônica, a idéia de ressurreição, eternidade, glória e inferno são predominantes no Cristianismo além de que, a doutrina cristã encontra também no corpo, por meio da castidade, um caminho à divindade [Isto é visto também por outras religiões ou seitas heréticas]. ${ }^{5}$

Segundo essa visão, enquanto a idéia de amor teria sido platônica, a primeira manifestação de amor, enquanto uma relação pessoal de apaixonamento vivida entre duas pessoas teria surgido fora do casamento, como uma aspiração latente de uma sociedade de grande instabilidade política e fecundidade espiritual, os trovadores da nobreza feudal do sul da Antiga Gália.

Esses trovadores ou poetas eram senhorios semi-independentes e teria nascido entre eles e, se estendido mais tarde a outras regiões da Europa, um amor chamado cortês. Tal amor se consolidou na ideologia de uma sociedade, num ideal de vida superior, num modo de viver ou de morrer.

Segundo as análises de Duby e Georges (1990) a sociedade feudal mantinha os jovens solteiros, com exceção dos primogênitos, e tentava casar as filhas excluídas da partilha de sucessão lhes entregando dotes, devido ao temor à fragmentação do patrimônio vivido por essa sociedade. Por esse motivo, o século XII teria se transformado no tempo dos jovens cavaleiros celibatários, sonhadores em vão em obter uma donzela com quem fossem um dia se casar. De acordo com essa apreciação, a moral e as estratégias dos costumes feudais teriam favorecido o jogo da relação amorosa entre um cavaleiro e uma dama aristocrática.

\footnotetext{
${ }^{5}$ No oriente, o culto a castidade, embora ter sido iniciado como um método de alcançar a longevidade cumpre também a mesma função do ocidente, a de ser um exercício capaz de fortalecer espiritualmente o homem, permitindo o grande salto da natureza humana em direção ao sobrenatural.
} 
Alguns historiadores como Johnson (1987, apud Lins, 1997) acreditam, no entanto, que o amor cortês teria sido uma continuação profana e deliberada do movimento maniqueísta ou catarismo, florescido na Europa na mesma época em que o amor cortês.

O catarismo era uma religião cuja crença fundamental, oposta à fé cristã, era o dualismo entre a luz e as trevas e a existência de duas criações, pois pregava que Deus não poderia ter sido o único criador da Terra sendo ela regida também por tantas injustiças e mortes. Os cátaros dividiam sua Igreja em “perfeitos” e “simples crentes” e, por condenar a matéria e o amor, evitavam o casamento e o sexo. Consideravam o casamento um pecado, pois gerar filhos era propagar a matéria e condenavam o amor porque este amarrava a alma à matéria. Acreditavam que o amor verdadeiro era a adoração de uma mulher redentora, símbolo de pureza e luz, mediadora entre Deus e o homem. Assim, o casamento era tolerado apenas para o “crente comum” ou "simples crente”, o qual não deveria ainda ver a sua esposa como uma mortal ou como uma companheira sexual, exclusivamente.

Retomando a perspectiva de Paz (2001), as crenças do amor cortês não teriam tido afinidades nem com o catarismo, nem com os dogmas cristãos. Nessa visão, a cortesia ou o amor cortês enquanto um sentimento elevado, próprio das cortes senhoriais, não tendo por fim nem o mero prazer carnal, nem a reprodução, apontava a diferença entre “a corte” e “a villa": se de um lado havia o amor cortês, amor purificado, refinado e capaz de ser aprendido; de outro se encontra o “amor villano”, que significava copulação e procriação.

O amor cortês também condenava o casamento, mas por uma razão muito diferente do catarismo: pelo fato do casamento ser constituído por intermédio de um vínculo contraído de acordo com interesses materiais, políticos e/ou familiares e quase sempre sem a vontade ou consentimento da mulher. Por este motivo que o amor cortês exaltava as relações fora do casamento, desde que fossem consagradas pelos laços do fin'amors e não conduzidas com lascívia. Outra divergência entre o amor cortês e os ideais cátaros era o 
desprezo ao culto à matéria presente no catarismo, uma vez que o amor cortês valorizava o corpo belo. Assim, o que era "santo” para os poetas adeptos do amor cortês era "pecado" para os cátaros ${ }^{6}$.

A divergência entre a Igreja Católica e os adeptos do amor cortês, na perspectiva de Paz (2001), consistia principalmente no fato dos últimos serem contra o casamento, pois a partir do momento em que o casamento foi sacramentado, qualquer atentado contra este sacramento era uma heresia. A formação, a cultura e as crenças dos poetas eram cristãs, mas muitas de suas aspirações manifestavam divergências com os dogmas da Igreja Católica. Afinal, julgavam o casamento injusto e escravizador da mulher enquanto sacramentavam o amor fora do casamento, conferindo aos amantes uma dignidade espiritual. O adultério assim como pela Igreja Católica, era condenado como lascívia pelos adeptos do amor cortês, mas se fosse ungido pelo fluído misterioso do fin'amors podia certamente ser convertido em sacramento. Havia ainda mais uma diferença entre os dogmas cristãos e aqueles dos adeptos do amor cortês: enquanto para a Igreja não devesse haver união carnal dentro do casamento se não tivesse por fim a procriação, para os adeptos do amor cortês essa finalidade era indiferente.

Sob essa ótica, o amor cortês tendeu ainda, a equilibrar a inferioridade social da mulher ao envolvê-la na relação amorosa entre um homem e uma mulher, pois propiciou a ascensão dela na ordem social, demarcada pela sua superioridade no domínio do amor.

Desse modo, o amor teria sido pensado de início, nas sociedades ocidentais, fora da religião oficial e visto pela Igreja Católica com inquietação e com reprovação. Teria assim, sido filho da filosofia e do sentimento poético, enquanto em outras localidades como o mundo islâmico, a Índia e o Extremo Oriente, formas análogas ao amor cortês teriam recebido influências religiosas.

\footnotetext{
${ }^{6}$ Os cátaros foram considerados hereges e perseguidos pela Igreja Católica, tendo seus livros e tratados queimados pela Inquisição.
} 
Em oposição à perspectiva de Paz (2001), a historiadora Marchello-Nizia (1996) afirma não somente a relação entre o amor cortês e a cavalaria como a relação entre estes dois e os dogmas da Igreja Católica.

O regime feudal formava uma estrutura piramidal, na qual os vassalos rendiam homenagens aos senhores, os senhores eram subordinados aos senhorios e, estes últimos eram subordinados aos reis, que rendiam homenagens somente a Deus.

A fidelidade era o alicerce dessa sociedade de modo que o jovem servia obediência ao senhor feudal por meio da cavalaria e à Igreja por meio do amor cortês, o amor desvinculado do sexo e dirigido a uma dama casada.

Nessa visão, a cavalaria, um grupo social, profissional e ético dos príncipes teria se oposto de início aos clérigos e aos camponeses, mas envolvido toda a sociedade da época justamente quando a Igreja começou a cristianizar os ideais do cavaleiro feudal. Desse modo, o amor cortês teria levado o jovem medieval a desenvolver qualidades como a coragem, a bravura, a obediência e a servidão ao senhor, a dama teria sido uma peça fundamental para que o jovem mostrasse suas virtudes, entre elas, a fidelidade ao senhor feudal e o amor cortês teria sido o responsável por garantir a tentação do adultério e prevenir as tentações da carne. Em contrapartida, o casamento precoce era também desejado e praticado nessa época, pois inibia a tendência ao sexo e a promiscuidade [o que não era vivido somente entre os villanos, mas certamente também nas relações ilícitas].

Entre os séculos XI e XV com o desenvolvimento da centralização política e do capitalismo comercial se iniciou um processo de desintegração do sistema feudal, de modo que o amor cortês e a cavalaria teriam permanecido até o final da civilização provincial, no século XV.

Como vemos, a Igreja Católica relutou, no início, em aceitar o casamento. Depois conjugou a ele a sexualidade como sua condição primordial e encontrou nessa instituição 
uma condição capaz de reprimi-la, de reforçar a autoridade hierárquica, bem como possibilitar a realização dos ideais cristãos.

Desse modo, da Idade Média à Idade Moderna as atitudes e os comportamentos sexuais foram endossados de formas eficazes pelo sentimento de pecado e por meio das regras da Igreja Católica e de seus representantes oficiais. No século XVI surgiu um novo tipo de classe social, a burguesia [tendo ascendido socialmente por volta do século XIX] a qual incitou grandes modificações nas relações sociais e políticas e, conseqüentemente nas relações de linhagem, de casamento e de gêneros, modificando também, as idéias sobre o amor em nossa sociedade, contribuindo para o surgimento do ideal do amor romântico. Veremos no próximo subcapítulo quais e como foram essas transformações. 


\subsection{O surgimento da família burguesa, a sexualidade e a ascensão do ideal} do amor romântico.

"Oh, pedaço de mim

Oh, metade afastada de mim

Leva o teu olhar

Que a saudade é o pior tormento

É pior do que o esquecimento

É pior do que se entrevar.

Oh, pedaço de mim

Oh, metade exilada de mim

Leva os teus sinais

Que a saudade dói como um barco

Que aos poucos descreve um arco

E evita atracar no cais.

Oh, pedaço de mim

Oh, metade arrancada de mim

Leva o vulto teu

Que a saudade é o revés de um parto

A saudade é arrumar o quarto

Do filho que já morreu.

Oh, pedaço de mim

Oh, metade amputada de mim

Leva o que há de ti

Que a saudade dói latejada

É assim como uma fisgada

No membro que já perdi.

Oh, pedaço de mim

Oh, metade adorada de mim

Leva os olhos meus

Que a saudade é o pior castigo

E eu não quero levar comigo

A mortalha do amor, adeus”.

Chico Buarque 
O nascimento da burguesia no século XVI determinou que a linhagem fosse substituída pela família conjugal, incitou as idéias de maternidade e endossou, juntamente com as transformações sociais ocorridas no período, o estabelecimento de papéis sexuais e sociais diferenciados entre homens e mulheres. Com a criação das escolas se iniciou também a idéia de infância como fases distintas da vida e a idéia de adolescência. A valorização do amor individual presente na ideologia burguesa cultuou a idéia de que o casamento devesse ser resultado do amor romântico e esta se fortaleceu fortemente por volta do século XIX (Lins, 1997; Ariès, 1981).

A partir do século XVI, com o início do capitalismo, ocorreu a transferência da produção econômica dos feudos para as fábricas, provocando a divisão entre o mundo público e o privado. O novo mercado de trabalho mal absorvia os homens e por isto, as mulheres foram incentivadas a permanecerem no lar. Quando a “área doméstica” começou a se opor à “área pública”, acentuou-se o afastamento entre sociedade e grupo familiar, surgindo um novo tipo de família, a família burguesa e se promoveu transformações radicais na relação do ser humano com o seu trabalho, com o mundo ao seu redor e consigo próprio.

Com a divisão da sociedade em mundo público e privado, os laços entre pais e filhos foram acentuados e essas relações ganharam os contornos da afetividade. Porém, embora essa divisão ter contribuído para a emancipação dos indivíduos das restrições sociais e possibilitou a vivência de maior intimidade no núcleo familiar trouxe, no entanto, limitações, especialmente às mulheres e às crianças. Instalou-se uma autoridade privada, patriarcal, dentro da família. As normas na família burguesa foram regidas por rigorosas divisões dos papéis sexuais que, colocaram a mulher no espaço privado do lar enquanto o homem continuou no espaço público dos negócios, e lançaram a criança numa situação de completa dependência e submissão aos pais. Nesse contexto se iniciou a “dupla moral” entre homens e mulheres que teve como conseqüências principais: a abstinência sexual para as 
mulheres após o nascimento do número de filhos desejado e com isto, a prática da atividade sexual dos homens com as prostitutas [comportamentos que repercutem até os dias atuais, embora os avanços das contracepções modernas] (Chauí, 1991; Vaitsman, 1994).

Segundo as análises de Lins (1997), a “dupla moral” teria sido conseqüência do surgimento do amor romântico [o qual teria se consolidado fortemente apenas no século XIX, quando a burguesia se proletarizou pelo trabalho assalariado].

Seguindo essa ótica, o amor romântico transformou o comportamento dos homens frente às mulheres, mas deixou uma estranha divisão nos sentimentos: se de um lado, os ocidentais passaram a ver a mulher como a encarnação de tudo o que era puro, sagrado e completo; por outro, submetidos à mentalidade patriarcal, a viam também como seres inferiores e como veículos do sentimentalismo, da irracionalidade, da apatia, da fraqueza e da passividade.

Essa moral responsabilizou a mulher, enquanto um assexuado e angelical, pelo amor maternal e zelo pela sobrevivência dos filhos, pela perfeição moral destes e pelos cuidados com o marido e com a casa. Ao homem, um ser másculo e dominador, capaz de sublimar os impulsos sexuais, ser agressivo, racional e ativo, coube a detenção da autoridade dominante sobre a família e o provimento de seu sustento.

Desse modo, o homem que amasse e respeitasse a sua esposa não deveria ligá-la a idéia de relação sexual, devendo o amor do homem para com a mulher assumir formas poéticas, simbólicas e imaginativas.

Na perspectiva de Johnson (1987 apud Lins, 1997) teria sido o amor cortês, o qual transformara o comportamento dos homens frente às mulheres, em relação à afinidade, aos sentimentos elevados, à experiência espiritual e à ânsia de beleza e este amor, amadurecido, teria se transformado na concepção moderna de amor romântico. A vibração transcendental contida na adoração do amor cortês não podia se misturar com o relacionamento pessoal, 
com o casamento ou com o contato físico, mas, segundo este autor, as mudanças sociais ocorridas após o processo de industrialização teriam incitado a transformação do amor cortês para o amor romântico, com a idéia de que o casamento devesse ser ungido a esse tipo de amor.

Murano (1992 apud Lins, 1997) corrobora com a idéia de que a sociedade industrial foi responsável pelo surgimento do amor românticio. Com o início da Revolução Industrial, [inaugurada na Europa na segunda metade do século XVIII] começou a ser vantajoso para a sociedade da época que a família se transformasse em um microcosmo privado e que o consumo existisse entre as várias famílias pequenas. Desse modo, o culto ao amor romântico se ligava a construção das famílias e conseqüentemente ao aumento do consumo.

Nessa visão, o surgimento da família burguesa e do ideal do amor romântico teria correspondido à nova requisição social: às exigências para o consumo, aos ideais de igualdade e liberdade explícitos na ideologia francesa, à solidificação dos princípios cristãos e à moralização do Estado.

Lins (1997) também afirma que o amor romântico não fora desconhecido da época pré-medieval, atentando para uma de suas características tão presente naquela época quanto agora: a dificuldade que temos de enfrentar para possuirmos o objeto amado.

Nos dizeres de Russel (1955 apud Lins, 1997, p. 70):
A crença do valor imenso da mulher é efeito psicológico da dificuldade de conquistá-la, e creio que se pode afirmar que quando um homem não tem dificuldade de alcançar uma mulher, o seu sentimento por ela não assume a forma de amor romântico.

Os avanços da industrialização facilitaram, então, a ascensão da família burguesa e do ideal do amor romântico.

Segundo Zampieri (2004), o adultério feminino teria sido punido, na era da Revolução Industrial, com pena de reclusão, dando direito ao divórcio enquanto que, o adultério masculino era sujeito apenas a uma multa. 
A partir do século XIX, acrescentou-se um novo e importante elemento no campo social: os médicos assumiram um importante papel na sociedade e, em especial, na família, ocupando-se da sexualidade por meio de objetivos normativos.

De acordo com Chauí (1991), os saberes dos movimentos médico-higienistas, reforçados pelos ideais cristãos, afirmaram ainda mais a importância da sublimação dos impulsos referentes ao sexo, do valor da monogamia, da indissolubilidade do casamento e dos cuidados com os filhos burgueses e contribuíram desse modo, para a legitimação das diferenças entre os homens e as mulheres e, conseqüentemente, para a desigualdade entre os gêneros e para a desvalorização da mulher.

Ao se apropriar da família para fazer valer os seus preceitos, o discurso médicocientífico se dedicou a profilaxia e a classificação dos comportamentos sexuais desviantes, ao estudo das doenças sexualmente transmissíveis e, voltando seu olhar para as crianças e suas necessidades, visou também que esta tivesse um desenvolvimento sadio. Desse modo, classificou todo e qualquer comportamento sexual em saudável ou patológico.

O conhecimento médico sobre a sexualidade se pulverizou no discurso e na prática de uma série de especialidades: psiquiatria, ginecologia, urologia, endocrinologia, clínica de doenças infecciosas, genética, entre outras, determinando o que devia e o que não devia ser relacionado ao sexo, à sexualidade e a diferença sexual.

Segundo Loyola (1999), o psiquiatra vienense Richard Von Kraft-Ebing foi um dos primeiros a transformar uma série de interditos e normas sexuais em postulados científicos regulados de acordo com a exigência da reprodução da espécie e dos ideais cristão de amor a Deus e à família. Ao orientar-se por esse eixo e pela organização de possíveis desvios dele, o trabalho inicial de Kraft-Ebing descreveu o comportamento sexual dentro de um quadro de categorias patológicas amparado pelo Direito, com uma metodologia capaz de prover opiniões psiquiátricas em casos legais. Contudo, como os modelos advindos de seu 
estudo: "sadismo, masoquismo e fetichismo" se concentravam na experiência subjetiva interna do indivíduo e não no comportamento observável, o psiquiatra acabou por deslocar toda a discussão científica do exercício em patologia para um projeto psicológico.

Na virada do século XIX para o século XX, as normas sexuais passaram a ser regidas não somente pela Medicina, pela Pedagogia e pelo Direito, mas por um conjunto de disciplinas e técnicas relativas ao comportamento sexual que se responsabilizaram pela institucionalização dos saberes sexuais e que envolveram também a Psicanálise, a Economia e a Demografia. Dentre estas disciplinas a Psicanálise teve sua importância destacada por ter sido a primeira a considerar a sexualidade infantil e por abrir e ao criar um novo universo para o significado da sexualidade com essa afirmação e com os conceitos de inconsciente, de conflitos psíquicos fundamentais, de origem sexual das neuroses, entre outros. Ao fundamentar a criança como um ser dotado de impulsos sexuais, Sigmund Freud encontrou argumentos para mudar a concepção de sexualidade ligada a finalidade de procriação e refutou a identidade sexual e genital, concebendo a existência de uma sexualidade que não é simplesmente genital e não tem a ver com a procriação somente, mas com a obtenção de uma satisfação.

Retomando Chauí (1991, p. 28), houve durante o século XIX um duplo deslocamento, do poder do saber religioso se passou ao poder do saber científico: “[...] da aberração pecaminosa passou-se para a doença e sua etiologia; do ato sexual passou-se a fragmentos dele" e se consolidou o fenômeno chamado "repressão sexual” [que teria se iniciado no século XVI com a origem da sociedade burguesa e capitalista].

A “repressão sexual” se refere ao:

sistema de normas, regras, leis e valores explícitos que uma sociedade estabelece no tocante a permissões e proibições nas práticas sexuais genitais (mesmo porque um dos aspectos profundos da repressão está justamente em não admitir a sexualidade infantil e não genital), os quais são estipulados pela religião, pela moral, pelo direito e pela ciência (CHAUÍ, 1991, p. 76). 
A definição de Chauí (1991) explicita a afirmativa contida no fenômeno da “repressão sexual”, isto é, que a repressão não se refere somente ao que é proibido, mas também ao que é permitido e desejável, segundo a sociedade. Nessa ótica, o fenômeno possibilitou a quebra da simples naturalidade biológico-animal do sexo, realizando a passagem do sexo visto como natural para o sexo visto como fenômeno cultural e histórico.

Para Chauí (1991, p. 127), a crença na família enquanto eterna, natural, universal e necessária teria ainda lhe aparelhado para “justificar, reforçar e reproduzir a repressão sexual”, enquanto que os vícios sexuais [aqueles comportamentos frente à sexualidade reprovados pela Igreja e pela medicina] foram considerados capazes de destruir, corromper, perverter, envenenar, desviar e depravar essa instituição tão essencial à humanidade.

A família tornou-se um lugar sagrado, o perfeito ninho para a realização das relações sexuais lícitas entre homem e mulher:

Até o quarto do casal se fechou, recolhido, secreto e respeitado como um templo inviolável: só os cônjuges, a partir o século XIX, o freqüentam, os servidores aí entrando apenas para a limpeza e na ausência do casal, os únicos a terem trânsito mais livre no santuário sendo o médico e o padre confessor ou o pastor. Os trajes de dormir se multiplicam: além da camisola, o roupão e a toca, escondendo cada vez mais os corpos conjugais, mas também os dos irmãos e servidores (CHAUí, 1884, p.131).

Como base nos autores apresentados até o momento, vemos que a sexualidade transita na história humana e se reveste de diversas formas e nomes, modificando-se pelo tempo e espaço. Assim, diferencia-se de uma sociedade e cultura à outra, mesclando suas práticas em justificativas quanto à permissão e a proibição de normas e regras sexuais, conservando ou contraindo as finalidades que cada sociedade e também cada indivíduo atribui ao sexo.

Segundo a ótica de Costa (1994) o termo sexo pode ser compreendido atualmente em dois aspectos: biológico e psicológico. 
Em seu aspecto biológico, o sexo é composto pela parte física ou corpo sexual, que é constituído por momentos da gestação e definido como sexo cromossômico, gonadal e genital. O sexo cromossômico é identificado pelo par $\mathrm{XX}$, referente à mulher e, $\mathrm{XY}$, referente ao homem; o sexo gonadal se relaciona com as glândulas gonodais: os ovários, na mulher e os testículos, no homem; e o sexo genital se refere aos genitais externos e internos no homem (pênis, bolsa escrotal e canais deferentes, próstata e vesículas seminais) e na mulher (pequenos e grandes lábios, vulva, vagina e ovários, tubas uterinas, útero).

Em seu aspecto psicológico, o sexo é composto pela identidade sexual ou genital, pela identidade de gênero e pela construção da orientação afetiva e sexual. A identidade sexual ou genital é estabelecida quando a criança desenvolve a consciência sobre o seu próprio corpo pela diferenciação e semelhança física entre ela e seus pais concluindo o que é ser uma menina ou ser um menino. A identidade de gênero se estabelece na adolescência quando a partir do surgimento dos seus caracteres sexuais secundários o indivíduo pode definir o que é masculino e o que é feminino Além disto, a identidade de gênero constrói-se também de acordo com o que a sociedade compreende em determinado momento sobre o que é masculino e o que é feminino, sendo tal identidade, portanto sempre em reconstrução. A construção da orientação afetiva e sexual se inicia psicologicamente por volta dos quatro ou cinco anos de idade sendo que, somente na adolescência o indivíduo é capaz de ter consciência de seus sentimentos, pensamentos e ações em relação às transformações de seu corpo, a exaltação dos hormônios sexuais e ao interesse afetivo e sexual pelo sexo oposto ou pelo mesmo sexo. A orientação afetiva e sexual se refere à sensação interna de se ter a capacidade para se relacionar afetiva e/ou sexualmente com alguém de sexo diferente ou mesmo sexo.

O sexo cromossômico, gonodal, genital interno e externo e os caracteres sexuais secundários pertencem ao campo biológico; a identidade sexual, genital e de gênero e a 
orientação afetiva e sexual pertencem ao aspecto psicológico e os papéis sociais, de gênero e afetivo e sexual pertencem ao social.

Nessa perspectiva, é necessário que o corpo seja provido das necessidades sexuais básicas e que o psiquismo tenha se desenvolvido observando os três fatores fundamentais, a identidade sexual, de gênero e a orientação afetiva e sexual para que o indivíduo exerça em plenitude a sua sexualidade.

O termo sexualidade se refere então "ao conjunto de fenômenos da vida sexual, apresentando-se interligada de maneira complexa e imbricada em seus aspectos biológicos, psicológicos e sociais” (COSTA, 1991, p.01).

Segundo o "Vocabulário da Psicanálise” de Laplanche \& Pontalis (2001), o termo sexualidade se caracteriza por uma grande plasticidade em relação à história pessoal de cada um de nós e não se refere às atividades que dependem somente do aparelho genital, mas à toda uma série de excitações e atividades que nos proporcionam prazer, desde a infância. Nessa ótica, a sexualidade é polimorfa: ultrapassa a necessidade fisiológica, relaciona-se com a simbolização do desejo e não se confunde com um instinto ou um objeto, o parceiro, e nem com um objetivo, o da união dos órgãos sexuais no coito, pois qualquer região do corpo é susceptível ao prazer sexual, desde que seja investida de erotismo.

Na passagem do século XIX para o século XX, tivemos ainda o combate à sífilis e as doenças venéreas. Contudo, as mudanças ocorridas nas últimas décadas do século XX também demarcaram um lugar importante na sexualidade e no campo familial. Aproximadamente por volta dos anos 80, tivemos o advento da AIDS, no mesmo período em que se acentua também a emancipação feminina. A autonomia das mulheres e a difusão da contracepção moderna teriam incitado o que Giddens (1993), chamou de uma transformação brusca na sexualidade, isto é, uma sexualidade mais descentrada, liberta das 
necessidades de reprodução e fundamentada na reivindicação da mulher ao prazer sexual e à emancipação no relacionamento denominada de sexualidade plástica.

Na visão de Vaitsman (1994), o surgimento da indústria e da urbanização acabou por abalar a dicotomia entre o público e privado, promovendo transformações marcantes no modo de construção das identidades masculinas e femininas, bem como na administração das relações de família e casamento, levando homens e mulheres, especialmente as mulheres, a redefinirem suas posições na sociedade.

Como conseqüência disto, nas últimas décadas do século $\mathrm{XX}$, se legitimou uma heterogeneidade de relações no campo familial e iniciou uma diluição das atribuições de gêneros.

Na ótica de Giddens (1993), a emancipação sexual e a autonomia das mulheres teriam contribuído para o enfraquecimento do ideal do amor romântico.

Considerando os trabalhos de Vaitsman (1994) e Giddens (1993), importantes para compreendermos as relações afetivas e sexuais na contemporaneidade, os abordaremos no próximo sub capítulo.

Após ter traçado uma trajetória sócio-cultural e histórica acerca da família ocidental, se retomarmos as idéias de Hall (2002), sobre uma crise de identidade cultural e individual na atualidade, bem como a ótica de Giddens (1991), sobre a radicalização e universalização das ocorrências da modernidade e ainda se considerarmos a visão de Lipovetsky (2004), acerca da existência de um universo paradoxal, podemos afirmar que certas normas sociais ou valores tradicionais próprios da modernidade realmente se mantêm no período atual, embora reciclados pela lógica hipermoderna.

Desse modo, os paradoxos da contemporaneidade mesclam os comportamentos novos com os comportamentos existentes outrora, como é o caso da questão feminina segundo a perspectiva de Lipovetsky (2004). O autor diz que se certas normas ou funções 
tradicionais reservadas ao feminismo se mantiveram porque as mulheres se apropriaram delas a fim de auferir mais felicidade privada e não porque essas normas ou funções constituem um resquício do qual as feministas teriam que se verem livres. Desse modo:

Se as mulheres sempre mantêm relações privilegiadas com a ordem doméstica, sentimental ou estética, não é por simples inércia social, mas sim porque essas relações se ordenam de tal maneira que não mais entravam o princípio de autonomia e funcionam como vetores de identidade, de sentido e de poder privados: é do próprio interior da cultura individualístico-democrática que se reconstituem as trajetórias diferenciais dos homens e das mulheres (LIPOVETSKY, 2004, p.34).

A perspectiva de Lipovetsky (2004), considera a lógica hipermoderna capacitada para re-arranjar e reciclar o passado sem cessar.

Assim, veremos no sub capítulo a seguir como as relações afetivas e sexuais estão sendo interpretadas na contemporaneidade por autores como Giddens (1993), Vaitsman (1994), Costa, (1998), Luz (2001), Bruns \& Almeida (2004), entre outros. 


\subsection{A busca pelo ideal do amor romântico e o esvaziamento das trocas afetivas e sexuais inter-humanas: as configurações entre o estável e o efêmero.}

“Amor é um livro -Sexo é esporte Sexo é escolha - amor é sorte

Amor é pensamento, teorema Amor é novela - Seco é cinema Sexo é imaginação, fantasia Amor é prosa - Sexo é poesia

O amor nos torna patéticos Sexo é uma selva de epiléticos. Amor é cristão - Sexo é pagão Amor é latifúndio - Sexo é invasão

Amor é divino - Sexo é animal Amor é bossa nova - Sexo é carnaval Amor é para sempre - Sexo também Sexo é do bom - Amor é do bem

Amor sem sexo é amizade Sexo sem amor é vontade Amor é um - Sexo é dois Sexo antes - amor depois Sexo vem dos outros e vai embora Amor vem de nós e demora".

Rita Lee, Roberto de Carvalho e Arnaldo Jabor

Retomando a perspectiva de Johnson (1987, apud Lins, 2001) sobre o ideal do amor romântico, o autor afirma que o romance, o sexo e o casamento estão atualmente enlaçados como se isso fosse natural sem termos a idéia de que o amor romântico enquanto escolha individual entre duas pessoas fora uma inovação tão revolucionária que tem até hoje um resultado bastante desastroso. 
Não nos foi ensinado como manter o amor que sonhamos vivo depois da moral patriarcal ter-se desmoronado e do gosto pelo efêmero ter surgido. Desse modo, grandes expectativas acerca da felicidade do casamento passaram a envolver o ideal do amor romântico, as quais não puderam mais ser cumpridas quando aliadas à vida contemporânea:

O principal conceito que não se modificou no decorrer dos séculos é a crença inconsciente de que o "amor verdadeiro" deve ser uma adoração religiosa mútua tão irresistível, que nos faça sentir que todo o céu e a terra nos são desvelados através desse amor. Mas ao contrário de nossos antepassados "corteses", tentamos trazer essa adoração para a nossa vida pessoal, misturando-a com o sexo, o casamento, o preparo do café da manhã, as contas a pagar e os filhos para criar (JOHNSON, 1987 apud LINS, 2001, p. 71).

Corroborando com a idéia de desastre presente no ethos do amor romântico, Costa (1998) afirma a sustentação do ideal por três principais afirmações: (1) o amor é um sentimento universal e natural, presente em todas as épocas e culturas; (2) o amor é um sentimento surdo à voz da razão e incontrolável pela força da vontade e; (3) o amor é a condição sinequanon da máxima felicidade a que podemos aspirar. Ao afirmar que o amor é universal e natural maximizamos o seu teor de idealização e ao enfatizar o aspecto involuntário ou incontrolável do amor levamos à acentuação das sensações e dos sentimentos, em detrimento de crenças e julgamentos, realçando a fraqueza da racionalidade e da vontade.

Entretanto, Costa (1998, p.17) afirma o que já vimos no estudo de Paz (2001), a implicação da escolha nos relacionamentos amorosos:

A racionalidade está tão presente no ato de amar quanto as mais impetuosas paixões. Amar é deixar-se levar pelo impulso passional incoercível, mas sabendo "quem" ou "o que" pode e deve ser eleito como objeto de amor. A imagem do amor transgressor e livre de amarras é mais uma peça do ideário romântico destinada a ocultar a evidência de que os amantes, socialmente falando, são, na maioria, sensatos, obedientes, conformistas e conservadores. Sentimo-nos atraído sexual e afetivamente por certas pessoas, mas raras vezes essa atração contraria os gostos ou preconceitos de classe, "raça”, religião ou posição econômica-social que limitam o rol dos que "merecem ser amados". Na retórica do romantismo, o amor é fiel apenas à sua própria espontaneidade. A realidade social e 
psicológica dos sujeitos diz outra coisa. O amor é seletivo como qualquer outra emoção presente em códigos de interação e vinculação interpessoais.

Essa perspectiva considera que a associação entre o amor romântico e a vida privada burguesa transformou o ideal em um elemento de equilíbrio indispensável entre o desejo de felicidade individual e o compromisso com os ideais coletivos, mas afirma que com o tempo, o amor teve o seu valor hiper-inflacionado e a sua participação na dinâmica do bem comum quase nula. O desinteresse pelo mundo público provocou o retraimento dos indivíduos para a vida privada e à medida que o amor romântico foi se associa ao sexo e ao consumismo, refluiu para o interior do privado e se tornou cada vez mais o ideal de felicidade, deixando de ser um meio de acesso a ela para se tornar o seu atributo essencial. O amor se tornou a última razão do sujeito ao se deslocar para o centro imaginário do ideal de felicidade pessoal:

justamente quando seu universo moral de origem não pôde mais garantirlhe o poder ideal de outrora. Cercado de violência, competição, frivolidade, superfluidade, egoísmo desenfreado e indiferença, o amor ergueu-se como uma fronteira ou uma trincheira entre o sujeito moral e a barbárie do mercado. Mas, sitiado e fora do nicho ecológico original, perdeu a perfeição mítica que tinha. Enquanto foi emblema do cuidado com as gerações, da harmonia entre "sexos desiguais" e da família como "célula da sociedade", guardou a transcendência que o protegia do tempo e do uso; quando se tornou um sentimento a mais na dieta dos prazeres a quilo, passou a ser visto como qualquer coisa ou pessoa na cultura do consumo: perdeu o interesse, lata do lixo! (COSTA, 1998, p.20).

Seguindo essa ótica, embora ter ocorrido uma fragilização no ideal do amor romântico amoroso pelo seu não atendimento às expectativas, a liberação e a emancipação das chamadas minorias sexuais e a pluralização da identidade teriam ainda incitado a busca pela identidade amorosa como "um derradeiro abrigo num mundo pobre em Ideais de Eu" (COSTA, 1998, p. 20).

Desse modo, ao exaltar grandes expectativas em torno do amor e da felicidade do casamento o ideal do amor romântico nos criou paradoxos no palco atual: 
Vivemos uma moral dupla: de um lado, a sedução das sensações; de outro, a saudade dos sentimentos. Queremos um amor imortal e com data de validade marcada: eis sua incontornável antinomia e sua moderna vicissitude! (COSTA, 1998, p. 18).

Giddens (1993), corrobora com a idéia de Costa (1998), dizendo que o amor romântico fora enfraquecido por algumas influências que ele mesmo ajudou a criar como: as idéias de exclusividade e durabilidade do amor recíproco, pois ao se tornar um ideal de casamento, ele introduziu um aspecto importante à relação conjugal: colocou a prova a sua duração.

Nessa visão, o ideal do amor romântico ao se enfraquecer abriu caminho para a formação de novos e alternativos relacionamentos como, por exemplo, o relacionamento puro e o amor confluente.

O relacionamento puro diz respeito a uma situação em que o indivíduo entra em uma relação social apenas pela própria relação e só continua nela enquanto ambas as partes considerarem que extraem dela satisfações suficientes. $\mathrm{O}$ amor confluente se associa ao relacionamento puro e por apregoar a igualdade de trocas afetivas e sexuais no envolvimento amoroso introduz a ars erótica no centro da relação amorosa transformando a reciprocidade do prazer sexual em elemento chave para a continuidade ou dissolução do relacionamento. Dessa forma, o amor confluente entra em choque com os atributos para sempre e único do ideal do amor romântico. A sexualidade plástica, por sua vez, se relaciona a emancipação feminina implícita no relacionamento puro.

Estas três categorias criadas por Giddens (1993), têm como base princípios igualitários e de igualdade.

No contexto brasileiro, alguns estudos também se referem a tais princípios como, por exemplo, a pesquisa de Salém (1989), que ao investigar o casal grávido nas classes médias, obteve recursos para cunhar o termo “casal igualitário”. 
O casal igualitário valoriza o companheirismo, busca a completude, estimula o investimento individual de cada parceiro e centraliza a díade em relação às famílias de origem. A reciprocidade e a dependência afetiva do casal igualitário são marcadas pela interdependência e complementariedade simétrica de modo que, masculino e feminino podem experimentar o lugar e a identidade do outro. No entanto, esta visão reconhece que na tentativa de conjuminar dois em um na relação e de conciliar os projetos individuais com os familiares impera o grande impasse do casal: a expressão da difícil convivência entre dois indivíduos concebidos como singulares e a existência do dual e/ou familial.

Atestando essa mesma idéia individualista-igualitária, outros autores criaram termos na tentativa de apreender as relações afetivas e sexuais na contemporaneidade. Entre eles Vaitsman (1985) cunhou o termo “coabitação separada”, referindo-se àqueles casais que em nome da preservação de um espaço próprio, da liberdade e da autonomia pessoal de cada parceiro optam por morarem em casas separadas. Moraes (1985 apud Salém, 1989) referiuse como singles àqueles indivíduos que alegando maior autonomia, privacidade e liberdade optam por morarem sozinhos. Heilborn (1980 e 1981 apud Salém, 1989) cunhou o termo “casal emancipado”, referindo-se àqueles que constroem seus projetos de relacionamento aberto, sobretudo na esfera sexual e proclamam a prevalência do indivíduo sobre a díade. Bauman (2004) denominou de “amor líquido” aquelas relações em que a presença da fugacidade e da flexibilidade dos laços afetivos resulta num curto tempo de duração e no aumento do sentimento de insegurança quanto a estas relações.

Todavia, Torres (2000), Vaitsman (1994), entre outros, discordam da possibilidade de que possam ocorrer relações igualitárias entre os gêneros, vendo isso como uma democratização entre as relações pessoais.

Recorrendo novamente ao trabalho de Vaitsman (1994, p. 15), realizado com homens e mulheres de classe média, sobre as transformações no casamento e na família nas 
últimas décadas, vemos que embora aponte o surgimento de uma família mais igualitária, a autora também não afirma a igualdade entre os gêneros, nem a extinção da família hierárquica. “[...] a família hierárquica não se tornou moderna, pois foi justamente a família moderna - e hierárquica - que nas classes médias urbanas veio sofrer a concorrência cada vez mais de novas formas de família”, o que desvela a persistência de elementos tradicionais coexistindo com comportamentos aparentemente contemporâneos.

No cenário português, ao pesquisar homens e mulheres casados entre si, de diferentes classes sociais, Torres (2000), encontrou freqüentemente nos discursos de seus entrevistados a visão do ideal do amor romântico, mas diz que esta sobrevive em detrimento de sentimentos de companheirismo, de solidariedade e de tranqüilidade à medida que os cônjuges envelhecem e por não reconhecer a igualdade entre os gêneros, propõe um modelo alternativo que denomina de amor construção. Este modelo implica na descoberta de sentimentos e aspectos novos na relação após o casamento com o decorrer do tempo; na desidealização do parceiro como um outro mais falível, mais previsível e mais próximo e; em maior paridade entre homem e mulher desde que reconhecendo as assimetrias existentes entre os sexos. Diz ainda que a relação conjugal pode caminhar para um o processo de reconstrução da relação bem como para a separação entre os parceiros.

Contudo, apesar dos modelos de negociação constante, baseados em princípios individualistas-igualitários, criarem uma idéia aparente de felicidade conjugal, na medida em que tudo pode ser negociado, Luz (2001) afirma que tais modelos podem ser danosos para a relação amorosa, pois ao se basearem num modelo contratual tornam-se capazes de desagregar o núcleo amoroso da relação amorosa e instituir uma espécie de vazio na dupla conjugal.

Nesse prisma, o sistema cultural dominante de individualizar sem cessar, seria interessante apenas para a economia e estaria tornando as relações socais desprovidas de 
sentido simbólico, se consideradas do ponto de vista sócio-antropológico. O consumismo e a competição individualistas apregoados pelo capitalismo estariam criando normas de rejeição e de exclusão do outro, com princípios de complementação na alteridade que beneficia apenas o sistema e não os indivíduos, isolando-os. E o individualismo seria capaz ainda de destruir redes de sociabilidade existentes como no caso da família, das comunidades de vizinhança e das relações solidárias coletivas estáveis, como outras também tão ou mais antigas do que estas: aquelas ligadas à reprodução, à sexualidade e ao amor.

Assim, para invertermos o movimento de vazio produzido pelas relações individualistas, fragmentadas e caóticas seria necessário nos contrapormos ao individualismo.

Corroborando com a visão de que as relações sociais e conseqüentemente as relações afetivas estariam esvaziadas de trocas afetivas e sexuais inter-humanas, Bruns e Almeida (2004, p. 21), apontam que uma análise sem cuidado sobre as relações relâmpagos parece indicar que "os seguidores desse modelo estão felizes, uma vez que a troca de parceiros(as), caracterizadas pelos contatos leves, rápidos e superficiais, protegeriam esses indivíduos de vivenciar sentimentos de inferioridade e impotência - hoje tão comuns entre nós”. Uma análise mais aguçada indicaria a carência de contatos afetivos significativos, de diálogos e de acolhimento vivenciada por nossa “geração@.com”.

Entretanto, nesse mesmo universo de relações frágeis, a ótica da psicanalista Dias (s/d) diz que uma família que se ramifica, que se reconstitui ou que forma composições sobrepostas estaria demonstrando um apego ao modelo de família nuclear [formada a partir da família burguesa, por mãe, pai e filhos até que a morte os separe], pois na medida em que essa família tenta figurar uma nova visão, recai paradoxalmente nas imagens do antigo modelo que se concebe como modelo ideal, desejável e bom. 
Não é de se admirar que ainda é dada importância aos dotes financeiros e econômicos do parceiro nas relações afetivas e sexuais na atualidade. A diferença de antes é que, num universo em que se prioriza o individual sobre o coletivo, tal importância e interesse se recaem aos dotes do parceiro e não necessariamente, aos de sua família.

A família, tornada monogâmica e indissolúvel, nos diz muito sobre a forma de vivenciarmos o amor e a sexualidade atualmente. A “dupla moral” e a divisão da sociedade em mundo público e privado nos trazem repercussões nos ideais e nas atitudes até hoje. Contudo, esses comportamentos mesclam-se a heterogeneidade de relações na família, a emancipação sexual feminina, à competitividade da mulher no mercado do trabalho, ao hedonismo, à valorização do corpo e ao gosto pelas formas e pelo efêmero, ao hiperconsumismo, à exaltação da individualidade, entre outros.

Dessa maneira, flagramo-nos num retrato multifacetado quanto às relações na família, na conjugalidade e fora destas instituições. É junto à família nuclear ou hierárquica que se estabelece uma pluralidade de formas de se relacionar: casamentos sucessivos; famílias ampliadas; arranjos monoparentais; altos índices de uniões informais; uniões homossexuais; casais sem filhos; filhos adotados, filhos de uniões anteriores e gerados a partir de inseminação artificial; namoros cada vez mais longos e, paradoxalmente relações relâmpagos; amor livre; amor e prazer virtuais.

Nesse cenário, a exaltação da individualidade ao mesmo tempo em que promoveu maior margem de liberdade e de escolha no plano das relações, incentivando uma maior democracia entre os gêneros, propiciou também uma superficialização das relações sociais, instaurando uma espécie de esvaziamento das relações afetivas, favorecendo o isolamento e a solidão. 
A medida em que se instalou uma crise de identidade cultural e se abalou a questão individual, o sexual foi abalado e na multiplicidade de modelos quebraram-se as referências quanto ao ser masculino e ser feminino.

Retomando Lipovetsky (2004), a sociedade mais flexível e mais comunicativa é marcada pelo frívolo, pelo supérfluo e pela inconstância das opiniões e das mobilizações sociais.

Entretanto, ao passo que a ética individualista nos coloca a possibilidade de que conjugalidade e de que família construir, o ideal do modelo de família nuclear e o ideal do amor romântico ainda permanecem em meio a formas alternativas de se vivenciar o amor e a sexualidade como: o amor livre, o swing, e o amor virtual, aquele empreendido pelos contatos via rede. Além disso, enquanto a exclusividade sexual parece poder ser negociada é também praticada e almejadas por muitos.

Diante das diversas visões apresentadas pelos autores, percebemos que tanto no que concerne a classificação do período em que vivemos, quanto na tentativa de apreensão das novas e alternativas formas de se relacionar desde que os quadros estáveis da modernidade foram abalados, as idéias expressam a lógica paradoxal inerente a esse momento histórico.

Neste palco, apresentamos a seguinte questão: homens e mulheres deixaram de encontrar na família e na conjugalidade o grande centro de auto-realização pessoal e social?

Com base nos autores expostos percebemos que o amor romântico não acabou, mas se aliou a novas formas de pensamento e de comportamento. Homens e mulheres se modificaram, mas não é por isto que suas relações não possam estar carregadas de sentido simbólico e de afeto. As relações na família transpõem limites, criam novas dificuldades que ultrapassam os valores conjugais, pois encerram paradoxos sociais, refletem a crise de identidade exposta. 
Contudo, precisamos compreender que à medida que se re-criam modelos ou formas de se relacionar não se quer dizer que a conjugalidade e a família não sejam mais importantes em nossa sociedade. Se atualmente somos capazes de reconhecer a pluralidade nas relações sociais, não deveríamos encontrar no individualismo um problema, como nos colocou Luz (2001), mas reconhecer a sua existência, sem nos esquecermos da importância de ser um como o encontro com o outro, na afetividade, como no social. Pois o homem é um ser biológico, psíquico, sócio-cultural, subjetivo e especialmente afetivo, o que significa que é um “ser-aberto-ao-mundo”, isto é, em constante transformação com o outro e carregado de afetos.

A busca pela individualidade, longe de ser algo oposto às exigências das amarras sociais, apresenta-se como justamente o seu reverso. Numa sociedade em que valores como o consumismo e a competição pessoal são valorizados, a individualidade aparece mesmo como um fenômeno de não contraposição a uma exigência social.

Desse modo, indivíduo e sociedade não se contrapõem, compõem infinitas possibilidades, formam o retrato da família na sociedade atual numa expressão de subjetividades tão universais quanto individuais.

Nesse palco de transformações sócio-culturais e tecnológicas nosso foco de atenção se volta para os significados que homens e mulheres atribuem a infidelidade amorosa do(a) parceiro(a) e como re-significam a relação afetiva e sexual após essa vivência na atualidade, significados que podem ser obtidos, em totalidade, somente na dimensão vivencial do sujeito.

Entretanto, veremos no próximo capítulo o que alguns autores como Gonçalves (2002), Zampieri (2004), Comte-Sponville (1995), Wright (1994) e Baker (1996) dizem sobre a infidelidade do casal. 


\title{
CAPÍTULO 2 - INFIDELIDADE: UMA LEI, UM PECADO, UM VALOR, UM ESQUECIMENTO, UMA GUERRA DE ESPERMAS?!
}

\begin{abstract}
“A mulher viu que a árvore era boa ao apetite e formosa à vista, e que essa árvore era desejável para adquirir discernimento. Tomou-lhe do fruto e comeu. Deu-o também a seu marido, que com ela estava, e ele comeu. Então abriram-se os olhos dos dois e perceberam que estavam nus; entrelaçaram folhas de figueira e se cingiram”.
\end{abstract}

Gênesis 3, 6-7

Durante a história sócio-cultural da família ocidental pudemos observar que mesmo antes do casamento tornar-se monogâmico e indissolúvel a infidelidade feminina, caso houvesse, era punida com morte, excomunhão ou abandono da mulher pelo esposo, como uma forma deste restituir a sua honra. Observamos também que, a relação de fidelidade em si fora o alicerce da sociedade feudal. A fidelidade ao senhor e à Igreja ocupou o lugar do código, da lei e do poder naquela época. Com a ascensão da burguesia e conseqüentemente do capitalismo, a fidelidade em si foi aos poucos perdendo a sua esfera de ação. A burguesia preocupou-se em reger somente a vida privada e a fidelidade em si passou a fazer cada vez menos sentido, enquanto reguladora dos relacionamentos públicos. Em contrapartida, a infidelidade feminina foi considerada degradante e perigosa na época vitoriana. A sociedade do século XIX, esmerada na dicotomia dos papéis sexuais e na "dupla moral” teve entre seus objetivos, o de transformar a mulher impura e infiel em inocente e fiel e, desse modo, a importância da fidelidade ateve-se ao campo das relações amorosas, mais do que em qualquer outro.

Nos dias atuais, a infidelidade amorosa é ainda considerada pecado e, em algumas culturas, crime também. Entretanto, o adultério masculino foi e tem sido, em toda a história da sexualidade, mais bem aceito que o adultério feminino, em virtude do mito da 
natural necessidade de sexo e da variação sexual que os homens possuem, sendo encarado como “uma fraqueza lamentável, mas compreensível” (ZAMPIERI, 2004, p. 157).

Não esqueçamos, por isso mesmo que, as relações de poder, dominação e subordinação compõem a permissibilidade ou a proibição dos comportamentos e atitudes, no âmbito sexual.

Assim, a sociedade monogâmica, tendo por base a fidelidade ao cônjuge, seja ela feminina ou masculina, sempre encobriu desde as suas origens, as ocorrências ilícitas das relações afetivas e/ou sexuais fora do casamento.

A Igreja Católica insiste na indissolubilidade do casamento, podendo existir um novo casamento somente após a morte de um dos cônjuges. Mas há ainda, na sociedade contemporânea judaico-cristã ocidental, alguns grupos como os mórmons discidentes, que residem no oeste dos Estados Unidos, que praticam a poligamia. No Egito, teria surgido uma prática que consiste na sutura dos grandes lábios da vulva para impedir a cópula com penetração vaginal e a inserção de um dispositivo metálico, como uma argola, para inviabilizar o coito, com o objetivo de assegurar a fidelidade da esposa. Prática ainda encontrada, ocasionalmente, no leste da África. Em outras culturas, a poligamia ou a poliginia, união em que um homem tem mais de uma esposa, sob aceitação legal, podem ser comuns. Os zulus, sul-africanos, políginos, punem o adultério feminino surrando os transgressores com galhos espinhosos e, até mesmo enfiando um cacto na vagina das mulheres. Os cheyennes, indígenas norte-americanos, castigam os transgressores com a curra, estupro cometido por um grupo de homens que se revezam violando a vítima. Africanos da região do Congo sudanês, no Zande, punem a mulher adúltera e seu amante pela morte ou pela mutilação do amante, arrancando-lhe as orelhas, as mãos, o lábio superior e o pênis. Entre os tupinambás, indígenas brasileiros, há uma combinação entre a monogamia e a poligamia, ou seja, embora a poligamia seja permitida, a monogamia é a 
forma predominante de casamento. Há ainda culturas que possuem hábitos sociais de compartilhar a esposa com um visitante, como os esquimós, os quais recorrem a hospitalidade sexual e a troca de esposas como uma forma de trocar de identidade e confundir espíritos malignos durante uma situação adversa (ZAMPIERI, 2004).

De acordo com o "Dicionário UNESP do português contemporâneo” organizado por Borba (2004), a infidelidade significa: (1) transgressão da fé matrimonial ou do dever de fidelidade entre os cônjuges; (2) falta de exatidão ou nitidez; falha; (3) rompimento da fidelidade; traição; deslealdade; (4) traição amorosa; (5) falta de respeito ou obediência; enquanto adultério significa: quebra da fidelidade conjugal.

A construção sócio-cultural e histórica da monogamia nos deixa claro ainda que:

Mesmo que a fidelidade pareça ser uma questão individual, de consciência e de relação com o outro, a sociedade intromete-se para codificar e decidir: aqueles que são e aqueles que não são fiéis. Como reação, selam-se pactos, perversões. Pois a fidelidade a si não passa necessariamente pelo reconhecimento das leis (WAJSBROT, 1992, p.11).

Uma visão filosófica pode tratar a (in)fidelidade no campo da moral e não no campo da ética ou dos cumprimentos das leis sociais. Para Comte-Sponville (1995) a fidelidade pode envolver três domínios: (1) o pensamento; (2) a moral; e (3) o casal. Em seu livro "Pequeno tratado das grandes virtudes", o filósofo diz que a fidelidade antes de tudo é fidelidade à verdade, depois à lembrança da verdade, isto é, à verdade conservada, e que seria possível mudar de opinião quanto a ela desde que se tenha razão e dever para isto.

Nessa perspectiva, a fidelidade supõe a memória: só é possível sermos fiéis ou infiéis àquilo de que lembramos e nisso, a fidelidade e a infidelidade são formas opostas de lembrança, uma virtuosa e a outra, não. Antes de lembrar é preciso, contudo, querer lembrar e querer não mudar, sendo a fidelidade também vontade. Ser fiel para a moral é a fidelidade que o dever impõe. Assim, a fidelidade subordinada à lei moral não é 
simplesmente aquela submetida à temporalidade de uma lei universal, mas subordinada à historicidade de um valor em que se trata também de cada passado pessoal. A fidelidade à lei ou ao dever moral não é desse modo, a fidelidade à lei divina, mas humana; à lei universal, mas particular e não é a fidelidade atemporal, mas histórica de modo que, a fidelidade se encontra no princípio de toda moral.

Seguindo essa ótica, a fidelidade exerce a base de fundamento da moral, capaz de tornar possível a existência de qualquer virtude. Isto quer dizer que ela não é um valor entre outros, uma virtude entre outras:

ela é aquilo por que, para que há valores e virtudes. Que seria a justiça sem a fidelidade dos justos? A paz, sem a fidelidade dos pacíficos? A liberdade, sem a fidelidade dos espíritos livres? E que valeria a própria verdade sem a fidelidade dos verídicos? Ela não seria menos verdadeira, decerto, mas seria uma verdade sem valor, da qual nenhuma virtude poderia nascer (COMTE-SPONVILLE, 1995, p.25-26).

Sendo a fidelidade fiel a si mesma, no caso do casal, a fidelidade seria fidelidade ao amor e não ao amante. A fidelidade do casal por esse prisma não significaria exclusividade, pois a fidelidade nesta ótica, torna-se mutável. A verdade sim, seria o valor mais elevado que ela, e o amor, seria menos traído pelo amor, isto é, por um novo amor, do que pela mentira, ou seja, a infidelidade seria trapacear-se a si mesmo, na manutenção de uma relação aonde o amor não impere mais.

Que o amor se aplaque ou decline, é sempre o mais provável, e é bobagem afligir-se com isso. Mas quer se separe, quer continue a viver junto, o casal só continuará sendo casal por essa fidelidade ao amor recebido e dado, ao amor partilhado e à lembrança voluntária e reconhecida desse amor. Fidelidade é amor fiel, e assim é também o casal, mesmo o casal "moderno", mesmo o casal "livre”. A fidelidade é o amor conservado ao que aconteceu, o amor ao amor, no caso, amor presente (e voluntário, e voluntariamente conservado) ao amor passado. Fidelidade é amor fiel, e fiel antes de mais nada ao amor (COMTESPONVILLE, 1995, p. 35). 
Nos dizeres de Wajsbrot (1992, p.188): “Pode-se, sem hesitação, qualificar Dom Juan de infiel e Tristão de fiel? Para parecer infiel, quem pode no fundo saber quantas fidelidades foram necessárias, e para ser fiel, quantas traições?”.

A (in)fidelidade envolve nestas visões, a lembrança e o esquecimento à verdade. $\mathrm{O}$ esquecimento do amor jurado ou a sua ausência arranca da fidelidade o peso da palavra traição. No entanto, essas perspectivas nos colocam, na prática, uma situação difícil, ainda mais quando os compromissos assumidos entre os parceiros envolvem, para além das regras sociais e dos bens materiais, os bens humanos, os filhos do casal.

Nas palavras de Sibony (1992, p.13): “A fidelidade não é concedida de imediato, repousa numa troca, numa relação, num questionamento perpétuo que oscila entre dois pólos, o Eu e o Outro, quer se trate da relação com o amor, com a história ou com o divino”. Como vemos, o conceito de (in)fidelidade não se estabelece somente entre duas pessoas, mas entre idéias e também entre objetos, desde que aquele(a) ou aquilo seja caro à alguém. Desse modo, a pretensão, a exigência ou o cumprimento da fidelidade podem ser dirigidos à confiança depositada; ao exemplo admirado; à palavra empenhada; à devoção ao trabalho, ao estudo ou ao esporte; ao segredo do amigo; à obrigação ao irmão, à família, à comunidade, à religião, à pátria, à guerra; e por quê não se dirigir ao ódio, o que, para Comte-Sponville (1995), seria uma má fidelidade.

Focalizando a fidelidade do casal, podemos compreendê-la também pelo âmbito legal, no qual ela se fundou enquanto um dever de ambos os cônjuges. Porém, o ethos da (in)fidelidade se modifica de acordo com o ethos sócio-histórico-cultural e, desse modo, no Código Civil Brasileiro, este dever matrimonial sofreu alterações ao longo dos anos.

Em “Sinopses Jurídicas: Direito de Família (2002)”, o desembargador no Tribunal de Justiça de São Paulo, Carlos Roberto Gonçalves, apresenta uma abordagem concisa e 
objetiva sobre o Direito de Família, de acordo com a Lei n. 10.406, de 10 de janeiro de 2002 (Diário Oficial da União de 11-1-2002), que instituiu o novo Código Civil.

O Direito de Família se divide em quatro partes: Direito Pessoal, Direito Patrimonial, União Estável e Tutela, e Curatela e o casamento figura como Subtítulo I do Direito Pessoal.

Na ótica civil, casamento ou sociedade conjugal é o complexo de direitos e de obrigações que formam a vida em comum e é celebrado com observância das formalidades exigidas na lei, isto é, se constitui pela união estável entre um homem e uma mulher, com o objetivo de constituírem a família legítima.

O casamento celebrado sem as solenidades previstas na lei, sem a manifestação do consentimento dos nubentes ou ainda, entre pessoas do mesmo sexo é inexistente em nossa sociedade, mesmo existindo movimentos na tentativa de regulamentação da união entre pessoas do mesmo sexo.

De acordo com o art 1.511 do Código Civil é reconhecido ao casamento o efeito de estabelecer “comunhão plena de vida, com base na igualdade de direitos e deveres dos cônjuges”, sob o aspecto patrimonial e espiritual.

De acordo com o art. 226, $\S 1^{\circ}$ e $2^{\circ}$ da Constituição Federal, há dois modos de união legal: o casamento civil e o casamento religioso, com efeito civil. O novo Código Civil, de 10 de janeiro de 2002, disciplina o casamento religioso como sendo de duas espécies: com prévia habilitação (art. 1516, §1) e com habilitação posterior à celebração religiosa (art. 1.516, §2 ${ }^{\circ}$. A Constituição Federal assegura a todos o direito de credo autorizando a realização da celebração pela autoridade religiosa da religião professada pelos nubentes, bem como a validade civil do casamento religioso sendo condicionada, de 
acordo com o art. 1.515 do Código Civil, à habilitação e ao registro no Registro Civil das pessoas naturais.

De acordo com o $\S 3^{\circ}$ do art. 1.516 do Código Civil, o Registro Civil do casamento religioso é nulo se antes dele um dos consorciados tiver contraído casamento civil com outrem.

A união estável também é reconhecida pela Constituição Federal e pelo art. 1.723 do Código Civil como entidade familiar, sendo chamada de família natural. Quando a família é formada por somente um dos pais e seus filhos é denominada, de acordo com o art. 226, § $4^{\circ}$ da Constituição Federal, de família monoparental.

A união estável entre um homem e uma mulher sem o casamento foi chamada durante muito tempo de concubinato. O Código Civil de 1916, continha alguns dispositivos que restringiam esse modo de convivência. Proibia doações ou benefícios testamentários de um homem casado à concubina bem como a inclusão desta como beneficiária de contrato de seguro de vida. Com a legislação previdenciária alguns direitos da concubina foram reconhecidos, tendo a jurisprudência admitido outros, como por exemplo, o direito à meação dos bens adquiridos pelos esforço comum.

Desse modo, as restrições no Código Civil passaram a ser aplicadas somente aos casos de concubinato adulterino ou concubinato impuro, isto é, quando um homem vive com a esposa e mantém, concomitantemente, a concubina.

No caso em que havia entre os parceiros uma convivência duradoura, como marido e mulher e sem impedimentos de outra união, como no caso dos solteiros, viúvos, separados judicialmente, divorciados ou que tiveram o casamento anulado, a união era expressa por concubinato puro ou companheirismo. 
Atualmente, a expressão concubinato é utilizada para designar o relacionamento amoroso envolvendo pessoas casadas que infringem o dever de fidelidade, o adulterino, e que se configura de acordo com o art. 1.727 do novo Código Civil em "relações não eventuais entre o homem e a mulher, impedidos de casar”.

No entanto, como vimos, o $\S 1^{\circ}$ do art. 1.723 trata a convivência pública e duradoura entre pessoas separadas de fato, mesmo que não estejam separadas de direito, como união estável. E proclama ainda, de acordo com o art. 226, § $3^{\circ}$ da Constituição atual, que além da união estável entre o homem e a mulher dever ser reconhecida como entidade familiar, para efeito da proteção do Estado é um dever da lei facilitar a sua conversão em casamento.

Desse modo, tratando-se de sociedade conjugal ou de união estável a lei estabelece deveres recíprocos entre os parceiros.

O art. 1.566 do Código Civil impõe aos cônjuges ou companheiros deveres recíprocos considerados importantes para a estabilidade conjugal sendo que, segundo o art. 1.573 do Código Civil, a infração de qualquer um desses deveres é considerada causa para a separação judicial.

Os deveres recíprocos no casamento são: (1) fidelidade recíproca; (2) vida em comum, no domicílio conjugal (coabitação); (3) mútua assistência; (4) sustento, guarda e educação dos filhos e; (5) respeito e consideração mútuos.

O Código Civil de 1916, tratava dos direitos e deveres do marido e da mulher em capítulos distintos [afinal, as oposições e diferenças entre masculino e feminino eram ainda mais acentuadas que agora]. Mas o novo Código Civil disciplinou somente os direitos de ambos os cônjuges, afastando as referidas diferenças. 
Desse modo, a chefia da sociedade conjugal, a administração dos bens comuns e particulares da mulher, o direito de fixar o domicílio da família e o dever de prover a manutenção da família que, no código Civil de 1916 eram direitos do homem passaram a ser exercidos pelo casal no sistema de co-gestão, de modo que homem e mulher foram obrigados a concorrer na proporção de seus bens e rendimentos, para o sustento da família e da educação dos filhos, seja qual for o regime matrimonial. Qualquer divergência deve ainda ser solucionada pelo juiz.

O dever de coabitação não deve ser encarado como absoluto, pois uma impossibilidade física ou moral, como a ausência de um dos cônjuges em razão de doença ou de trabalho, pode não significar quebra do dever de vida em comum. O que caracteriza o abandono do lar é o que se chama animus, isto é, a intenção de não mais regressar à residência comum. É admitido aos parceiros residir em locais separados desde que se inclua a obrigação de manter relações sexuais, o debitum conjugale, pois a recusa reiterada do cônjuge em manter relações sexuais caracteriza injúria grave, podendo ser causa de separação litigiosa, ou seja, a separação judicial a pedido de um dos cônjuges que atribui culpa ao outro, por cometer qualquer grave violação dos deveres do casamento, o que torna a vida em comum insuportável (separação-sanção).

De acordo com o art. 1.572, caput, do Código Civil, a separação judicial pode ser pedida também se um dos cônjuges provar a ruptura da vida em comum há mais de um ano com a impossibilidade de sua reconstituição (separação-falência), ou quando um dos dois cônjuges estiver acometido de doença grave (separação-remédio).

O dever de mútua assistência implica a prestação recíproca de socorro material, como também, a assistência recíproca moral e espiritual, sendo sua ausência, também causa de separação litigiosa. De acordo com o art. 1.576 do Código Civil, a assistência 
mútua deve subsistir até mesmo depois da separação judicial, até que não ocorra o divórcio.

O dever de sustento e a educação dos filhos, também constitui dever de ambos e a guarda é ao mesmo tempo dever e direito dos pais. É subsistente a obrigação de sustentar os filhos menores e lhes dar orientação moral e educacional mesmo após a dissolução da sociedade conjugal, extinguindo-se este dever com a maioridade ou somente com a obtenção do diploma universitário, no caso dos filhos estudantes que não dispõem de meios para estudar sem o auxílio dos pais.

O dever de respeito e consideração mútuos se pauta pelo princípio de igualdade de direitos e deveres dos cônjuges e tem relação com o aspecto espiritual do casamento e com o companheirismo que nele deve existir, demonstrando a intenção do legislador de torná-lo mais humano.

Entretanto, nosso alvo nesse momento se refere à compreensão do dever de fidelidade recíproca, uma decorrência do caráter monogâmico do matrimônio, cuja infração se configura como adultério e se caracteriza como causa para a separação judicial litigiosa. Este dever exige uma abstenção de conduta enquanto os outros deveres reclamam comportamentos positivos. E para se constituir como transgressão basta somente uma prova da infidelidade, sem a exigência de que o culpado mantenha a persistência de uma relação extra-conjugal.

Este dever perdura enquanto subsistir a sociedade conjugal e, mesmo quando os cônjuges estiverem separados, extinguindo-se apenas pela morte, nulidade ou anulação do casamento, separação judicial, divórcio ou mesmo morte presumida do ausente.

O namoro, os encontros em locais comprometedores ou públicos e os atos preparatórios da relação sexual não constituem adultério, sendo a sua existência 
dependente do congresso sexual completo. Os atos pré-sexuais são denominados apenas de adultério tentado ou adultério não consumado ou quase-adultério. A inseminação artificial é chamada de adultério casto ou científico, apesar da opinião contrária de alguns doutrinadores que não o consideram pelo fato de não haver cópula. A mulher poderá dar causa à separação judicial caso venha a se sujeitar à inseminação artificial recebendo o sêmen de outro homem, sem o consentimento do marido. Isto se constitui em comportamento desonroso e em injúria grave. Igualmente, o homem casado se fornecer sêmen para a inseminação de mulher desconhecida sem o consentimento da esposa, também seu comportamento é considerado injúria grave.

A lei determina ainda que, se um dos cônjuges infringir os deveres matrimoniais, o outro não passa a ter o direito de, impunemente, praticar o adultério.

De acordo com o art. 219, IV, do Código Civil de 1916, revogado tacitamente pela Constituição Federal, o defloramento da mulher ignorado pelo marido, error virginitatis, era causa de anulação do casamento por erro essencial quanto à pessoa do outro cônjuge e denominado de adultério precoce. A hipótese de adultério precoce exigia a propositura da ação anulatória no exíguo prazo decadencial de dez dias pelo cônjuge enganado. Não era exigido a prova de mau comportamento da mulher, caso houvesse sido vítima de estupro, supondo-se que o marido não a desposaria, se a soubesse deflorada. O novo Código Civil, de 10 de janeiro de 2002, não considera motivo para anulação do casamento o defloramento da mulher ignorada pelo marido [o que podemos ver uma adequação da lei à realidade, em virtude de mudanças morais e políticas produzidas pela sociedade]. A isonomia jurídica entre o homem e a mulher que inclui a igualdade de tratamento quanto aos direitos e deveres, proclamada na Constituição Federal atual, já autorizava dizer que não mais subsistia o tratamento diferenciado à mulher quando a sua virgindade antes do casamento, considerado injusto e retrógrado. Desse modo, o inciso IV 
do art. 219 do Código Civil de 1916, que considerava tal fato o erro essencial quanto à pessoa do outro cônjuge foi revogado tacitamente.

O art. 1.576 do novo Código Civil prescreve: “A separação judicial põe termo aos deveres de coabitação e fidelidade recíproca e ao regime de bens” devendo permanecer os outros três deveres: mútua assistência, sustento, guarda e educação dos filhos e respeito e consideração mútua.

No caso da união estável, o art. 1.724 do novo Código Civil que regula as relações pessoais entre os companheiros declara que os companheiros devem obedecer aos deveres de “lealdade, respeito e assistência e de guarda, sustento e educação dos filhos”, estando o dever de fidelidade recíproca implícito nos de lealdade e respeito. E de acordo com o Supremo Tribunal Federal, Súmula 382, a não inclusão do dever de coabitação é justificada pela compreensão de que atualmente, a vida em comum sob o mesmo teto, more uxório, não é indispensável à caracterização do companheirismo.

Com base na obra de Gonçalves (2002), ressaltamos que a Lei Civil considera ainda o adultério de difícil prova porque resulta da “conjunção carnal entre duas pessoas de sexo diferente que é praticado, em geral, às escondidas”. Além disto, ao considerar a possibilidade da ocorrência do adultério somente entre um homem e uma mulher, a Lei Civil manifesta a extensão e cumprimento da lei que caracteriza o que é o casamento em nossa sociedade, a união legal e/ou estável entre um homem e uma mulher e, não entre pessoas do mesmo sexo.

Gonçalves (2002), afirma ainda que, em geral, os advogados não fundamentam o pedido de separação litigiosa pela ocorrência do adultério, mas em injúria grave, justamente pela prova dos atos preparatórios à infidelidade ser suficiente para a decretação da separação culposa. 
Desse modo, ao contrário do revogado art. 317 do Código Civil de 1916, que especificava como causas de separação litigiosa: o adultério, a tentativa de morte, a sevícia, a injúria grave e o abandono voluntário do lar conjugal durante dois anos contínuos, a Lei Divórcio indica como causas de separação litigiosa atualmente: a conduta desonrosa e a grave infração dos deveres do casamento.

No Brasil, o divórcio foi introduzido pela Emenda Constitucional $n^{\circ}$ 9, de 28 de junho de 1977 que, deu nova redação ao $\S 1^{0}$ do art. 175 da Constituição de 1969, suprimindo o princípio da indissolubilidade do vínculo matrimonial, como também, estabelecendo os parâmetros da dissolução que, seria regulamentada por lei ordinária. [A Lei do Divórcio indicou que algumas mudanças, como abordamos no Capítulo 1, ocorriam na vida doméstica e ao mesmo tempo, parece ter sido um dos incentivadores da recomposição da família].

No início, com o Decreto $n^{\circ} 181$, de 1890, que instituiu o casamento civil no Brasil, era previsto o divórcio a "thoro et mensa" que, acarretava somente a separação de corpos, mas não rompia o vínculo matrimonial. O divórcio que rompe o vínculo e permite novo casamento, o divórcio vincular ou a vínculo, foi aplicado no Brasil somente com a regulamentação da emenda constitucional pela Lei $n^{\circ}$ 6.515, de 26 de dezembro de 1977, cuja modalidade básica, o divórcio-conversão requeria três anos para que a separação fosse convertida em divórcio. O divórcio direto previsto nas disposições transitórias (art. 40) servia somente aos casais que já estavam separados de fato, há mais de cinco anos, em 28 de junho de 1977. A constituição de 1988 reduziu o prazo da separação de fato para um ano, no divórcio-conversão e, criou uma modalidade permanente e ordinária de divórcio direto desde que, comprovada a separação de fato por mais de dois anos. A Lei nº 7.841, de 17 de outubro de 1989, limitou-se a adaptar a Lei do Divórcio à nova Constituição, dando nova redação ao art. 40, excluindo qualquer possibilidade de discussão a respeito da 
causa eventualmente culposa da separação desde que se comprove a separação de fato, por mais de dois anos. Atualmente, o novo Código Civil se limita a proclamar que o divórcio é uma das causas que ensejam o termino da sociedade conjugal, tendo o condão de dissolver o casamento válido (art. 1.571, IV e § 10). E de acordo com o art. 226, § 60, da Constituição, os encontros esporádicos entre os cônjuges, sem o ânimo de reconciliação, não tem o condão de interromper o prazo da separação de fato ensejadora do divórciodireto desde que, comprovada a separação de fato por mais de dois anos.

Contudo, embora a Lei Civil regulamente a fidelidade como dever conjugal, na realidade, a fidelidade amorosa, como o seu reverso, não se restringe ao âmbito do casamento regulamentado ou à função sexual genital, mas permeia também o espaço das relações entre os casais de namorados, sejam essas relações heterossexuais, homossexuais, genitais ou não.

Além disso, a (in)fidelidade do casal é abordada por diferentes aportes teóricos que vão além dos já mencionados: os da moral, do religioso, do sócio-cultural, do jurídico e do filosófico, fazendo também paragem à literatura, à mitologia, à dramaturgia, aos evolucionistas, à mídia contemporânea, aos psicanalistas, entre outros.

Para alguns evolucionistas, a fidelidade ou o refreamento da poligamia é explicado pela pressão da seleção natural sob a espécie humana e/ou por alguns aspectos biológicos da espécie.

Wright (1994), argumenta que muitos de nossos sentimentos morais possuem fundamento biológico e afirma que em algum momento de nossa história um extenso investimento masculino nos filhos teria penetrado em nossa linhagem evolutiva. Nessa perspectiva, a estratégia de “vagar, seduzir e abandonar” não beneficiaria os genes masculinos, caso os filhos gerados fossem devorados. As crianças que tivessem pai e mãe teriam também, uma pequena vantagem educacional sobre as crianças que tivessem 
apenas um dos pais. Isto teria feito com que as fêmeas desenvolvessem a tendência a formar pares. Desse modo, a seleção natural teria tomado o cálculo de custo-benefício e o transformado em emoção, principalmente quanto ao sentimento amoroso, incentivado à monogamia. O amor teria tido uma base inata e não sido uma invenção da cultura ocidental. Esse autor afirma ainda que, na atualidade, embora alguns casais assumam a monogamia, a poligenia de fato e a monogamia seriada, expressa nos casamentos sucessivos são recorrentes.

Na perspectiva de Baker (1996), uma característica fundamental e biológica nos homens, o tamanho de seus testículos, estaria determinando aqueles que devem ser fiéis ou infiéis às suas parceiras. Os homens com testículos maiores produzem mais espermatozóides diariamente e injetam mais gametas em cada relação sexual e por este motivo, têm mais chances de serem infiéis e de se relacionarem com uma parceira que também lhes serão infiel. Estes homens estariam competindo com outros homens de testículos grandes numa guerra de espermatozóides. Os homens com testículos menores, ao contrário, estariam se especializando em cuidar de suas parceiras e, em serem fiéis. Segundo autores como Buss (2000 apud Zampieri, 2004) e Baker (1996), entre outros, a escolha de um homem por uma mulher, desde as habitações costeiras australianas até os zulus da África do Sul, estaria fundamentada no desejo de que o parceiro escolhido pudesse oferecer bons recursos genéticos e econômicos, a fim de garantir a sobrevivência e o melhor desenvolvimento dos filhos. Nesta ótica, a busca pelo(a) parceiro(a) estaria determinada pelas diferenças entre os gêneros de modo que as mulheres estariam procurando em seus parceiros: ambição, inteligência, saúde, poder, confiabilidade, criatividade, status social, profissional e recursos econômicos e; os homens, buscando em suas mulheres: beleza e saúde, como sinônimo de fertilidade; bem como a exclusividade sexual, como garantia de paternidade. Entretanto, os autores afirmam que a mulher 
contemporânea desejaria ainda parceiros adicionais, em virtude da função crucial de garantir sua segurança e a de seus filhos, como uma sabedoria ancestral.

Contudo, se compartilharmos as idéias destes evolucionistas, teríamos que negar a construção teórica da qual apresentamos até o momento, ou seja, deveríamos desconsiderar a influência da igreja, da cultura e da sociedade nas construções das relações familiares, das relações afetivas e sexuais e das relações de gêneros.

Considerando a ressonância que a infidelidade encontra na mitologia e na literatura ao longo dos anos, podemos dizer que infida é Eva do Gênesis, como Sofia dos gnósticos, Pandora, Dalila e Helena de Tróia. Podemos saudar os contos de Clitemmnestra e Egisto, Lancelote e Genebra, Tristão e Isolda, entre muitos outros, bem como Penélope que, aguardou fielmente o retorno de Ulisses de sua longa viagem, tecendo e desmanchando sua tapeçaria, pois caso fosse concluída deveria se casar com um de seus pretendentes.

$\mathrm{Na}$ literatura brasileira, Capitu, na obra machadiana desvelou muito bem, pelo retrato vivo do antigo e jovem companheiro de Bentinho, Esbobar, expresso no corpo e na voz de seu filho, o diálogo silenciado que o cônjuge infiel mantêm com o seu parceiro e com os demais. Tal diálogo é consistente atualmente, em muitos relacionamentos de casais. Podemos citar ainda, o teor sexual e psicológico contido na dramaturgia de Nelson Rodrigues, obra de dimensão universal, na qual imperam as histórias de amor, de castidade, de prostituição, de loucura, de incesto, de morte e de traição.

Ao analisar a obra de Nelson Rodrigues, Martuscello (1993) vê a elaboração criativa propiciada pela arte enquanto uma alternativa aos sintomas psíquicos, isto é, um meio de metamorfosear a dor em prazer, como se os infortúnios, as angústias, os sofrimentos e os desejos não realizados possam ter seus feles transformados em algo mais agradável e mais bem aceito pela censura e pela autocrítica. Nas palavras do autor: 
Toda grande obra-de-arte provém de motivações emocionais importantíssimas para o autor. São sempre seus conflitos psicológicos, conscientes ou não, que funcionam como a principal mola propulsora da criação. E será sempre a identificação do leitor com estes conflitos a responsável pela sintonia indispensável que permite a acolhida e a aclamação da obra como sendo verdadeira. Uma vez preenchidos os requisitos estéticos que caracterizam a obra-de-arte em seus aspectos formais, aquilo que ela carrega e desperta a partir de seu conteúdo é que terá a capacidade de encontrar ou não no leitor uma ressonância significativa com o que ele traz em si de semelhante (MARTUSCELLO, 1993, p.07).

Desse modo, encontramos ressonância de nossas vivencias quotidianas não somente na literatura e na dramaturgia, mas como apontamos no Capítulo 1, nas revistas e nas telenovelas, em todo o mundo midiático, capaz de transpor as fronteiras do tempo, das raças e nações.

Entre as peças rodriguianas que abordam o tema da infidelidade amorosa, podemos destacar quatro delas:

(1) “A mulher sem pecado”, escrita em 1941, trata de um homem que, obcecado pelo ciúme em relação à mulher, faz-se passar por paralítico em um período de sete meses para testar a fidelidade da esposa. Quando se sente convencido da honestidade da esposa, esta havia fugido com o chofer do casal. Selecionamos uma frase da personagem masculina no ATO I que diz à esposa: "Não acredito em você. Por que você será sempre fiel? (...) Não é um inferno esta fidelidade sem fim?... A mulher de um paralítico tem inclusive o direito, quase a obrigação de ser-infiel” Rodrigues (1981 apud MARTUSCELLO, 1993, p.50).

(2) “Viúva, porém honesta”, escrita em 1957, aborda de forma jocosa a fidelidade feminina antes e depois da viuvez, opondo puritanismo à prostituição.

(3) “Boca de Ouro”, escrita em 1959, se refere a um "banqueiro de jogo do bicho”, que nasceu em uma "pia de gafieira” e a todo momento busca compensar o seu complexo 
de inferioridade. Ao assediar a mulher de um amigo que lhe devia dinheiro, foi assassinado por ele.

(4) A obra "Perdoa-me por me traíres", escrita em 1957, se refere à história de um marido traído que antes de obrigar a esposa infiel a tomar veneno destaca que o culpado pela traição da mulher é justamente o marido, já que a adúltera se salva do desejo de traição quando a realiza.

Para Martuscello (1993), em “A mulher sem pecado”, o marido contaria com a infidelidade da esposa mesmo antes dela acontecer, suscitando também a dúvida de que ele pôde ter contribuído para a infidelidade de sua primeira esposa. O texto expressa a dificuldade do homem em estimular a sexualidade da mulher, bem como a presença do amante na imaginação masculina, muito antes de se tornar realidade. Em "Viúva, porém honesta": "Classificar como adultério o segundo casamento de uma viúva pressupõe obrigatoriamente a existência de uma crença, ainda que apenas no plano da preferência fantasiosa, na eternidade da pessoa do marido" (MARTUSCELLO, 1993, p.17). A pretensão da fidelidade eterna, mesmo após o desaparecimento do marido, estaria pois, apontando para uma prova máxima de dedicação feminina assim como, na direção do narcisismo contido em "querer continuar presente na vida da esposa a despeito de toda a evidência em contrário” (MARTUSCELLO, 1993, p.17). “Boca de Ouro” reapresenta o nascimento do filho com a morte do marido, reivindicando o amor fidelíssimo e exclusivo da mãe e, tal como em “Viúva, porém honesta”, em “Perdoa-me por me traíres” revela o predomínio do fracasso das relações amorosas e do conseqüente sentimento de culpa e desejo de punição.

O Teatro de Nelson Rodrigues é até hoje, palco de interesse de muitos estudiosos da área literária, o que se justifique talvez, até mesmo pelo encontro significativo e ressonante entre a arte e a vida. 
Atualmente, com os avanços tecnológicos como o uso da internet, intensivo e globalizado, pertinentes questões referentes à sexualidade e ao amor, bem como às esferas da normalidade e do patológico são provocadas. Ao mesmo tempo em que a tecnologia nos oferece mais conforto e melhor qualidade de vida [em meio a maiores cobranças], nos deixa também perplexos diante de algumas situações tais como diante da tentativa de compreendermos a possibilidade de homens e mulheres vivenciarem o afeto e o sexo, online. No mundo cibernético, as traições virtuais nos levam mais uma vez a questionar acerca do que significa a infidelidade amorosa atualmente e, nos remete às indagações sobre o modo como vêm ocorrendo as relações afetivas e sexuais, as relações entre os gêneros e a própria educação sexual, na atualidade.

Diante deste cenário de transformações nas formas dos homens e mulheres vivenciarem o afeto e a sexualidade na atualidade, porém refletindo sobre a permanência de alguns valores tradicionais, podemos dizer que a questão da ética impera nos debates filosóficos e políticos de nosso tempo e uma discussão acerca do que é (in)fidelidade pode funcionar como um exemplo disto. Contudo, é no palco da sociedade de consumo, incitada pelo gozo e pela visibilidade imediata que o espetáculo da infidelidade faz, também, parte do show da mais poderosa de todas as mídias, a televisão.

Segundo Chauí (2004, p.8), a tela da televisão surge como uma passagem da produção da identificação à identidade, pois ela "não oferece modelos a imitar, mas se oferece como espelho no qual acreditamos estar refletida nossa própria imagem”.

Assim, a espetacularidade das mídias transforma a banalidade em exaltação, naturaliza a agressividade, inocenta o réu, abençoa o vilão e, muitas vezes, nos oferece um gozo imediato, naquilo no qual nos identificamos. O caso do Príncipe Charles, no qual sua infidelidade à esposa foi noticiado no mundo todo, é um exemplo com visibilidade. 
A rede de televisão britânica ITV anunciou em maio de 2005, a montagem de um filme sobre o romance do herdeiro do trono britânico com Camilla Parker-Bowles, cujo título é “Whatever Love Means”. O longa-metragem mostrará como o Príncipe Charles e Camilla se conheceram até o casamento dele com Diana Spencer, em 1981. De acordo com Timmer, diretor da produtora, o longa-metragem será um retrato vivo do amor e da amizade entre ele e Camilla antes de Charles ter conhecido e ter se casado com Diana Spencer. Ademais, o título do filme revela uma declaração dada por Charles a um repórter quando anunciou o seu noivado com Diana. Ao ser perguntado se estava apaixonado na ocasião, Charles havia exclamado: “É amor, seja o que isso for” (Revista Época, 2005).

Após o falecimento de Diana, em conseqüência de um acidente automobilístico, o Príncipe Charles se casou com Camilla Parker-Bowles no dia 08 de abril de 2005. Camilla se divorciou do brigadeiro Andrew Parker-Bowles em 1995, quando Charles já tinha se separado de Diana e admitido publicamente o seu adultério. Nos dias precedentes ao casamento foi noticiado ao jornal britânico The Sunday, pelo bispo de Salisbury, David Stancliffe que a missa do casamento de Charles incluiria orações de penitência visando “a reparação das ofensas, o restabelecimento das relações e uma atenção séria as relações rompidas por má conduta”, devendo o herdeiro da coroa britânica desculpar-se pelo adultério contra Andrew Parker-Bowles (Tudodibao, 2005).

Retomando Bucci e Kehl (2004), as operações midiáticas e, mais especialmente a televisão, é realizada como um dueto entre fato e ficção, quando nos noticiários, a realidade aparece como ficção e na ficção das telenovelas, esta aparece como realidade, ambos se inscrevendo no registro do entretenimento e da espetacularidade.

As operações midiáticas incorporam ações que, visam ao desejo e vão além dele, buscam o modo de produção do imaginário contemporâneo pela compreensão crítica da 
imagem enquanto imagem, seja no nível do inconsciente individual, como no nível do inconsciente social.

Para Chauí (2004), a televisão é violenta não pelos conteúdos que veicula, mas em sua forma intrínseca: na imagem enquanto imagem, uma vez em que ela pretende substituir o real e oferecer um gozo imediato, impedindo a crítica, o diálogo e a reflexão do telespectador, sendo persuasiva provocando atos sem mediação. A imagem é mantida pelo poder do modo de produção capitalista, o poder superindustrial, que é uma reprodução automática, transubstanciado em espetáculo.

Na visão da autora, o poder é a gestão do espetáculo no qual seus encarregados não são autores, mas subordinados.

Bucci e Kehl (2004, p. 20) enfatizam que a televisão funciona por convenções imaginárias, segundo por processos inconscientes, seja por parte dos emissores, como dos receptores:

As "novas necessidades expressivas" só se tornam (relativamente) conscientes quando advêm à palavra - mas aí talvez percam a graça e sobretudo a força, quando repetidas incansavelmente no repertório da TV. Os homens fazem a língua? Seria mais adequado dizer: a língua se faz através da fala dos homens. Os homens fazem a língua antes de saber o que dizem. Os homens fazem e consomem a televisão sem saber o que desejam.

Desse modo, Chaú́ (2004) e Bucci e Kehl (2004), consideram a televisão a mais espetacular tradução da indústria cultural, a mais poderosa mídia da sociedade do espetáculo.

Chauí (2004) afirma que, no caso do Brasil, a televisão reina praticamente sozinha e sem rivais sendo por intermédio dela que o país se comunica, se conhece e se reconhece.

Podemos então dizer que é nesta tela que a naturalização do desejo e da prática da infidelidade amorosa encontra ressonância da vida real. O personagem da televisão encena a realidade e, muitas vezes, a pessoa do ator confunde a ficção e a realidade. A tela retrata 
as alegrias e os infortúnios do quotidiano, as celebridades fazem e refazem os seus pares, as imagens atuam como simulacros do real e empregam constantemente os desafios de uma aliança e de seu rompimento, os paradoxos da infidelidade. Tais paradoxos transitam entre o que é jurado frente à Lei Civil e à Igreja e o que é praticado de fato; entre as motivações e necessidades de ser (in)fiel, que permeiam as relações de gêneros e as questões individuais; entre o anseio de termos um amante fiel e o gosto pelo hedonismo; entre o segredo que o infiel guarda num diálogo silencioso e a sua denúncia transparente no quotidiano; entre o que é fidelidade e o que é infidelidade, para uns e para outros; entre o que é o verbo e o que é a imagem!

Contudo, para Zampieri (2004), a infidelidade sexual é no plano psicológico, uma das forças mais dissociadoras do aspecto emocional do casal. A partir de sua prática clínica com casais brasileiros, de aproximadamente 27 anos, a pesquisadora afirma que este é um dos temas mais doloridos de se trabalhar na clínica psicológica.

Na obra intitulada: "Erotismo, sexualidade, casamento e infidelidade: sexualidade conjugal e prevenção do HIV e da AIDS” Zampieri (2004), aborda parte de sua tese de doutoramento, a qual foi defendida em 2002, na Pontífica Universidade Católica de São Paulo.

Para a autora, embora a infidelidade sexual deva ser entendida no entrelace entre psíquico, sócio-cultural e biológico, ela é ligada à quebra de confiança e do acordo sobre a exclusividade sexual, enquanto que o adultério é implicante nas preocupações religiosas e legais, independentes do relacionamento entre os parceiros. Assim,

A infidelidade não está no sexo, necessariamente, mas no segredo. É razoável supor que alguém que esteja mentindo a outra pessoa não está tentando criar proximidade, intimidade ou entendimento. As mentiras podem trazer conforto ou paz temporários para um relacionamento, permitir saídas rápidas, mas ao custo de fomentar desconfiança, desentendimento e distancia emocional (ZAMPIERI, 2004, p.169). 
Ao mesmo tempo em que ainda é uma justificativa para os divórcios, bem como uma força amenizadora para muitos crimes passionais, a infidelidade do casal revela em contrapartida, os pactos implícitos entre os parceiros conjugais na manutenção do segredo sobre a existência do amante, a fim de manter o casamento intacto.

A pesquisadora observou entre os cônjuges que cometeram a infidelidade sexual sentimentos como: culpa, confusão, medo do desmascaramento, medo de que o fato se repita e que resulte em instabilidade emocional. Sentimentos como amor, ódio, luxúria, repulsão, inveja, culpa, piedade, aversão, admiração, dependência e medo compõem a dinâmica conjugal e o ato da infidelidade sexual pode vir seguido de sentimentos de culpa, temor e ira contra o parceiro que foi traído, num esforço para responsabilizá-lo da própria infidelidade. Foi relatado o medo de contrair doenças sexualmente transmissíveis como a AIDS e o HPV (Papilo Humano Vírus), especialmente pelos mais jovens, bem como o medo de engravidar, no caso das mulheres. Com menos freqüência, alguns estimularam o cônjuge a ser infiel, no intuito de minimizarem o sentimento de culpa; passaram a desacreditar em seus relacionamentos. É comum que as pessoas dominadas pela culpa, depois de uma infidelidade, se distanciem do companheiro que nada suspeita, cujo amor faz com que se sintam ainda mais culpadas e, ao mesmo tempo, procure a única pessoa que pode aliviar a culpa: o que foi cúmplice no ato, aquele que pode assegurar que nada de errado foi feito. Nestas situações, a culpa pode solapar o casamento e alimentar as relações extraconjugais.

Os sentimentos vivenciados pelos cônjuges que sofreram a infidelidade sexual dos parceiros se referiram à: desejo de vingança, negação, desorientação, bem como levaram a abertura de uma crise conjugal e de distanciamento emocional. A culpa é um sentimento muito freqüente nas mulheres, o que para a pesquisadora revela o reflexo das repressões sexuais, as quais estão condicionadas até hoje a serem as responsáveis por todos os 
problemas, fracassos e dificuldades do casamento. O estudo desvelou ainda, a ocorrência de infartos do miocárdio contingentes à revelação da infidelidade do parceiro, bem como fortes sentimentos de angústia e, em alguns casos, até sentimentos de suicídio.

De acordo com seu estudo, a infidelidade sexual é mais freqüente em algumas etapas do ciclo vital do casamento: (1) Naquela que compreende os dois primeiros anos de casamento, possivelmente em função da vivencia do "luto da paixão", os homens. (2) Naquela que se refere aos casamentos com cerca de dez anos, cujos se encontram com problemas sexuais ligados à falta de desejo, nos quais os relacionamentos extraconjugais são vistos como tentativas de estabilizar ou sobreviver ao casamento ou de escapar dele. Nestes casos, a ambivalência quanto a ficar com o cônjuge ou com o novo parceiro, devido principalmente pela existência dos filhos ou por não querer separar os bens construídos e adquiridos, é ocorrente. (3) Naquela que se refere aos casamentos com mais de vinte anos, principalmente quando houve crises anteriores que não foram resolvidas, num momento em que os filhos saem de casa, o ninho se esvazia e o cônjuge busca novas relações afetivas e sexuais. E ela pode ocorrer ainda, em casamentos tidos como bons, isto é, casamentos nos quais os parceiros são sexualmente ativos, embora distantes emocionalmente.

A partir da análise de depoimentos de homens e mulheres, ela afirma que a infidelidade sexual pode ser considerada um ato desesperado de auto-afirmação ou uma forma de checar a capacidade de se sentir ainda atraente e desejável. Alguns de seus colaboradores expressaram suas necessidades de convicção de seus próprios atrativos, bem como de suas perícias sexuais. Outros afirmaram que este tipo de infidelidade nada

\footnotetext{
${ }^{8}$ De acordo com Zampieri (2004, p. 136): “um dos maiores paradoxos da vida erótica é que, apesar do desejo ansiar por satisfação, esta o refreia”. Desse modo, a fase denominada luto da paixão se refere a crise prevista no casamento devido ao impedimento ao relacionamento continuo. É natural que o desejo dos casais que moram juntos seja progressivamente difícil de ser sustentado.
} 
teve a ver com seus cônjuges e suas vidas sexuais com eles, enquanto alguns tentaram provocar o ciúme e o interesse dos parceiros. Algumas pessoas relataram a infidelidade sexual como decorrência do abandono afetivo e/ou sexual de seus parceiros ou por carência de intimidades para realizar posições sexuais que seus cônjuges não aceitavam ou ainda como uma forma de dizer ao parceiro que não os amam mais. Outros afirmaram que foram infiéis sexualmente para se vingar de fatos [reais ou imaginados], que seus cônjuges teriam cometido com a intenção de feri-los ou de acabar com o casamento. Outros relataram a busca pela revitalização de um casamento monótono ou a curiosidade para descobrir como seria estar com uma pessoa nova e diferente. Outros falam de seduções, nas quais a competitividade impera, exigindo a ostentação sexual em seus locais de trabalho ou grupos sociais. Alguns homens justificam-se pelas cortesias varonis, já que são constantemente seduzidos por outras mulheres de suas redes sociais. Outros são infiéis com pessoas do mesmo sexo, até mesmo por não terem assumido suas necessidades homo ou bissexuais antes do casamento. Houveram pessoas que revelaram sentimentos de pouco êxito sexual com os cônjuges, referindo falta de desejo, disfunção erétil e anorgasmia. Outras falaram em necessidades constantes de estarem apaixonados, os adictos de paixão ou Dons Juans e Senhoras Juanitas, além dos compulsivos sexuais. E houve ainda aqueles que relataram que seus relacionamentos não machucam ninguém e que ninguém tem a ver com esse tipo de atitude. Para Zampieri (2004, p. 167):

Essas pessoas não pensam no casamento como um acordo entre iguais. Elas não vêem o segredo com uma traição, um indicador de falta de confiança na parceria. A maioria das pessoas não consegue abandonar duas idéias sobre a infidelidade: de que ela é tão normal que não precisa ser mencionada e de que ela é tão perigosa que não deve ser revelada.

Segundo Zampieri (2004) existem padrões de infidelidade, os quais podem ser resumidos em quatro grupos, com base na direção em que a energia emocional é direcionada: 
(1) A infidelidade acidental se refere aos atos sexuais não planejados e incomuns deixando os envolvidos desorientados. Quando as infidelidades iniciais têm este perfil o desenrolar da situação dependerá da maneira como o infiel amador definirá e lidará com a nova situação. Caso ele compreenda a situação com naturalidade e se sinta à vontade, poderá se tornar um namorador. Estes sabem que estão fora de ordem e podem culpar a si mesmos ou as circunstâncias, tendo como emoções primárias, a culpa e a ansiedade.

(2) Os namoros infiéis se referem às atividades sexuais habituais que aparecem natural para o namorado e é motivada mais pelo medo e desejo em relação ao sexo oposto do que por quaisquer forças dentro do casamento ou pela relação sexual imediata. Estes estão obcecados pelo sexo oposto. No caso dos homens, despersonalizam tanto a mulher em casa, quanto a mulher na cama, importando apenas os corpos e os genitais e a vitória sobre o gênero oposto, tendo como emoções primárias, a raiva.

(3) Os casos românticos são "estados de louca paixão” que deixam os envolvidos confusos e os fazem se desinteressar por seu casamento e por sua família. A energia emocional encontra-se no romance, há a importância com o amor, mas antes disso, com a ausência de todas as outras emoções que seriam apropriadas para a sua sobrevivência.

(4) Os arranjos conjugais se referem a tentativas de se manter distancia desejada por um dos parceiros. Podem ser supridos pelas relações sexuais e constar de vinganças que podem manter casamentos turbulentos em estado de paixão e de ciúme. Nestes casos, o sexo acontece geralmente fora do casamento, mas a energia emocional é dirigida à ele. Existem ainda vários padrões diferentes de 
arranjos conjugais e nos casos em que não há o segredo, estes arranjos podem deixar de ser considerados infidelidades.

A pesquisadora aponta ainda para a crença no valor do ideal do amor romântico e sua implicação na dinâmica do casal e, em conseqüência na dinâmica da infidelidade:

[...] A maior parte delas [das pessoas], em idade de casar, não aprendeu a diferença entre romance e amor. O romance é uma história fictícia e maravilhosa. No entanto, a sociedade determinou que o romance seria a base para se escolher um parceiro para a vida. Quando a excitação romântica acaba, alguns se sentem iludidos ou enganados” (ZAMPIERI, 2004, p. 165).

$\mathrm{O}$ culto a virgindade feminina e a monogamia patriarcal necessitaram da instituição da prostituição para se estabilizar [como vimos, no Capítulo anterior]. O tema da infidelidade masculina é um revelador do panorama das relações de gênero, norteado pela educação sexual diferenciada que recebemos desde meninos e meninas e que é herdada pela cultura judaico-cristã.

Nos dizeres de Zampieri (2004, p. 165-166):

\begin{abstract}
As mulheres concebem tal questão [a da infidelidade masculina], como da ordem do regular dizendo que: as coisas são assim e que faz parte da natureza masculina a tentação de ter experiências sexuais variadas. Contudo, tal apreensão, que é consciente, não redunda em atitudes de prevenção ao HIV, à AIDS e a outras doenças sexualmente transmissíveis nas relações sexuais com os parceiros. Muitas mulheres acreditam que se previnem sendo simplesmente fiéis ao marido. Convivem, assim, com a percepção de um possível risco e um sentimento de indeterminação sobre o próprio destino, o que lhes impossibilita tomar uma atitude deliberadamente preventiva. $\mathrm{O}$ constrangimento feminino quanto à negociação do uso do preservativo se exprime por um sentimento de dependência do poder masculino, que impede o diálogo com os maridos sobre isso. Segundo elas, os maridos poderão usar camisinha com as outras; entretanto, não saberão realmente se o fizeram. Nem questionarão seus maridos.
\end{abstract}

Desse modo, o estudo de Zampieri (2004) aponta para uma questão vital: os gêneros, a infidelidade, as doenças sexualmente transmitidas e a morte. A autora diz que infidelidade sexual é um elemento importante para o trabalho da prevenção do HIV nos 
casamentos; que muitos tabus e preconceitos precisam ser revistos ou quebrados e; que o silêncio sobre os tabus da infidelidade sexual é o grande aliado para o aumento progressivo de esposas brasileiras infectadas pelo HIV, ou doentes com AIDS. Quebrar o silêncio da infidelidade sexual considerada criminosa enquanto um veículo de infecção do HIV é quebrar o silêncio que leva os seres humanos à subordinação e ao poder da ignorância.

Sabemos quão dolorosas podem ser as quebras do silêncio e do segredo da infidelidade na hetero, na homo e na bissexualidade. Mas quando estes silêncios e segredos tocam a ética das seguranças humanas diante da vida, as quebras do silêncio e das revelações são importantes (ZAMPIERI, 2004, p.173).

As repercussões da doença AIDS no mundo e as características dos principais grupos infectados: homossexuais e tóxicodependentes suscitaram de imediato uma resposta da sociedade aos comportamentos sociais moralmente julgados como desviantes.Os familiares são sobrecarregados com a notícia simultânea da doença e do comportamento de risco que gerou a AIDS. Tomar conhecimento deste fato pode gerar na família sensação de ter sido traída, que provoca um sentimento de raiva dirigida ao individuo doente, ou de culpa por não ter conseguido orientar conveniente seu parente. Devido a este cenário, o risco de casais heterossexuais se verem como portadores ou como possíveis portadores do HIV é mínimo, resultando em problema grave, visto que não se consideram sujeitos desta realidade, nem como receptores, nem com necessidades de prevenção. O fato do homem criar barreiras para o uso de preservativos no casamento incentiva o crença de que fora de casa fazem uso. Na relação hetero a confiança entre o casal pode ser instalada caso haja proteção do sujeito, havendo a desconfiança de uma traição (Zampieri, 2004).

A pesquisadora acredita que a fidelidade sexual exigida pelo homem à mulher, ao mesmo tempo em que eles não se obrigam a ser fiéis, provoca-lhes a sensação constante de insegurança, que muitas vezes traz o medo da entrega amorosa ou uma necessidade de 
autopromoção diante da mulher como forma de garantir um espaço de poder e de controle na relação. Afirma que a infidelidade masculina é taticamente aceitável entre muitos casais brasileiros sendo que, as mulheres pensam que a infidelidade de seus parceiros é apenas heterossexual e não homossexual. Os homens com comportamento bissexual são herméticos com atitudes escondidas e clandestinas e mantêm um relacionamento sexual com as esposas. Desse modo, as mulheres costumam negar a bissexualidade dos maridos e quando a descobrem adotam um comportamento compreensivo, uma aceitação passiva, nas diversas classes sociais.

Outros mitos permeiam o universo sexual da infidelidade, tais como: "que o infiel não ama mais o seu cônjuge”; “que o amante é mais sexy que o cônjuge”; "que a infidelidade é uma defesa contra possíveis infidelidades do parceiro”; “que a infidelidade sempre acaba em divórcio ou separação" e; por fim, "que a infidelidade é uma manobra anti fóbica de quem teme o sexo oposto”.

A construção sócio-cultural da sexualidade em relação à infidelidade, nos deixa claro ainda que:

Existe inclusive, um código de honra entre os homens para que não contem às mulheres sobre as infidelidades de seus amigos, colegas de trabalho ou parentes. [...] E contar as amigas sobre as infidelidades de homens conhecidos parece ser parte de éticas femininas. Aos homens foi ensinado que as mulheres reagem emocionalmente às coisas e que simplesmente não entendem as realidades do mundo e, particularmente, as realidades masculinas, de modo que cabe a eles protege-las de coisas que elas não entenderiam. As mulheres podem ser tão protetoras quanto os homens, fingindo vê-los como heróis enquanto os protegem como se fossem infantis. Uma coisa que se traz da infância é o medo de ficar desamparado ao admitir uma falha. A maioria dos pais pune as crianças que admitem seus erros. Assim, são ensinadas a mentir, supondo corretamente que serão tratadas com maior brandura, se os pais estiverem inseguros em relação a sua culpa. Assim também, homens e mulheres mentem uns para aos outros por medo de punições ou de rejeições (ZAMPIERI, 2004, p. 170-171). 
A autora conclui o seu trabalho dizendo que na sociedade dos produtos e das relações descartáveis, arrumar outro parceiro não é a mais simples e nem a única alternativa quando os problemas aparecem. Afirma a importância da necessidade de individuação, da quebra de mitos e tabus e da comunicação saudável, para que os casais possam também ter vidas sexuais saudáveis.

Compreendendo a sexualidade como um aspecto importante na relação do casal, optamos por considerar nessa investigação, a infidelidade amorosa enquanto a ocorrência da vivência da sexualidade fora do relacionamento do casal.

Nossa investigação se justifica pela possibilidade de ampliar a compreensão do fenômeno da infidelidade amorosa para os que trabalham com grupos familiares e lidam quotidianamente com esta questão, seja em pesquisas, estudos ou atendimentos clínicos, como os profissionais da área da Psicologia, da Psicanálise, da Sociologia, da Educação, da Filosofia, da Fenomenologia; além oferecer contribuições para a sociedade de modo geral, proporcionando reflexões sobre o modo como vêm ocorrendo as relações afetivas e sexuais, sobre as relações de gênero e sobre a própria Educação Sexual, no momento atual.

Contextualizar a infidelidade amorosa na sociedade contemporânea implica não somente examinar as modificações que a sociedade do consumo sofreu, e o modo no qual o homem contemporâneo se relaciona com estas transformações, mas também realizar uma análise sócio-histórica-cultural da construção deste fenômeno na sociedade ocidental.

Nessa trajetória de contextualizar o fenômeno no momento atual, o panorama que Zampieri (2004) nos coloca vem ao encontro de nosso foco de estudo: ao indagarmos sobre os significados atribuídos à vivência da infidelidade amorosa do (da) parceiro (a) e à resignificação da relação dual após a sua ocorrência, por homens e mulheres que foram traídos, pois, estamos tratando justamente, da dor psíquica. 
Em “Inibição, sintoma e angústia” (1926/1976) e em “O mal-estar na cultura” (1930/1976) Sigmund Freud se refere à perda do objeto amado, abordando tanto o amor, bem como a dor psíquica. Em “Luto e Melancolia” (1915/1976) Freud sublinha que “o ser que mais amamos é primeiramente uma instância psíquica” e argumenta o quanto essa instância psíquica se difere da pessoa amada. Freud constatou que o amado é primeiramente e, sobretudo, uma parte ignorada e inconsciente de nós mesmos que desaba se o amado desaparecer. Constatou também que nada é mais natural do que amar para evitar o conflito com os outros e que, paradoxalmente, nunca estamos tão mal protegidos contra o sofrimento quando amamos. É concordando com os estudos de Freud que Nasio (1997, p.27) afirma que "mesmo sendo uma condição constitutiva da natureza humana, o amor é sempre a premissa insuperável dos nossos sofrimentos. Quanto mais se ama, mais se sofre”.

Nos dizeres de Nasio (1997, p. 27): “O amado me protege contra a dor enquanto o seu ser palpita em sincronia com os batimentos dos meus sentidos. Mas basta que ele desapareça bruscamente ou me retire o seu amor, para que eu sofra como nunca”.

Em sua obra “O livro do amor e da dor” Nasio (1997) se dedica ao tema da dor psíquica e do amor realizando estudos exclusivos. Ao explicar detalhadamente o mecanismo de formação da dor psíquica, o autor engendra o que ele próprio chama de metapsicologia da dor e versa sobre o paradoxo incontornável do amor: “quanto mais se ama, mais se sofre”.

Com base na construção teórica de Nasio (1997) compreendemos que a experiência de dor psíquica é expressa na comoção pulsional ou autopercepção do eu sobre o tumulto interno desencadeado pela perda ou ruptura da imagem do outro amado, o que significa a ruptura de sua própria imagem. 
Compreendemos também que a re-significação da relação amorosa após a vivência da infidelidade do (da) parceiro (a) é necessariamente permeada pelo processo de luto. $\mathrm{Na}$ obra: “A separação dos amantes: uma fenomenologia da morte” Igor Caruso (1986) realiza um estudo minucioso de casos psicanalíticos e psicoterapêuticos abordando a separação física de pessoas que ainda se amavam e assim, os mecanismos de defesas empreendidos por estas no processo de luto e de sua elaboração.

É desejando demarcar o laço misterioso que nos liga ao amado eleito, bem como o sentimento de perda deste amado, que recorremos à autores como Juan-David Nasio e Igor Caruso, entre outros psicanalistas para nos auxiliar na realização da análise das descrições de homens e mulheres que colaboraram com essa investigação, ou seja, nos auxiliar na compreensão do fenômeno que indagamos, que visa desvelar os significados que homens e mulheres atribuem a vivência da infidelidade amorosa do(da) parceiro(a) e à resignificação da relação amorosa após essa experiência.

Assim, para realizar esta investigação, tivemos que adotar uma postura científica consoante nos planos ontológicos, epistemológicos e metodológicos. Utilizamos a metodologia de pesquisa qualitativa e o método fenomenológico descritivo, que apresentaremos no capítulo seguinte. 


\section{CAPÍTULO 3 - TRAJETÓRIA METODOLÓGICA QUALITATIVA}

"Somos vozes num coro que transforma a vida vivida em vida narrada e depois devolve a narração à vida, não para refletir a vida, e sim, mais corretamente, para agregar-lhe algo; não uma cópia, mas uma nova dimensão; para agregar com cada novela algo novo, algo mais, à vida”.

\section{Carlos Fuentes}

\subsection{O que é uma investigação qualitativa?}

Partimos da premissa que há diferentes lógicas de ação no campo da pesquisa científica. A crença do pesquisador no nível ontológico da investigação, isto é, a crença na natureza da realidade investigada irá determinar a sua postura em relação ao plano epistemológico, isto, é, a maneira da qual irá se relacionar com os colaboradores de sua pesquisa e/ou com o fenômeno a ser investigado, bem como a sua postura no plano metodológico.

Segundo Silva (1998), para adotar um método de ação é importante ainda que o pesquisador tenha conhecimento dos quadros de referência que condicionam e orientam as práticas de pesquisa, isto é, que informam e dão sentidos e rumos às práticas, pois respondem sobre o campo de inserção do trabalho, sobre a sua origem e sobre a construção do conhecimento aplicado. Os quadros de referência constituem uma espécie de matriz disciplinar que agrupa um conjunto de paradigmas. Ter conhecimentos sobre os quadros de referência existentes é importante para que o pesquisador não construa uma prática alienada, ou seja, é importante para que o pesquisador possa manter-se coerente dentro de uma mesma visão paradigmática e para que haja harmonia entre os níveis ontológico, epistemológico e metodológico de sua pesquisa, pois “a boa qualidade da pesquisa depende da congruência de seu desenvolvimento em relação à visão paradigmática que a fundamenta, e desta com as estratégias e análises adotadas” (SILVA, 1998, 173).

Na visão de Gialdino (1993 apud Silva, 1998, p. 160), paradigmas se referem a: 
marcos teórico-metodológicos de interpretação dos fenômenos criados e adotados por pesquisadores de acordo com: (1) uma visão filosófica de mundo; (2) a determinação de uma ou várias formas ou estratégias de acesso à realidade; (3) a adoção ou elaboração de conceitos ou teorias que se acredita ou que se supõe darem fundamento para o entendimento dos fenômenos; (4) contexto social no qual o pesquisador encontra-se; (5) a sua forma de compromisso existencial; (6) a eleição dos fenômenos que vai analisar.

Segundo Silva (1998), no campo da pesquisa, a Psicologia foi incitada a unir forças com as disciplinas interpretativas nas humanidades e nas ciências sociais devido ao fato do homem empregar atividades simbólicas na construção e na criação dos sentidos para a vida. Considerar essa visão ou esse paradigma significa assumir uma postura compreensiva ou interpretativa frente a uma determinada realidade investigada. Tal postura se fundamenta na resistência à naturalização do mundo social e às predições e generalizações contidas nos estudos sociais e prioriza o ponto de vista dos envolvidos nos fenômenos. É nessa visão paradigmática que se pautam as postulações das investigações qualitativas.

Entre alguns autores que trabalham com investigações qualitativas como Bogdan \& Biklen (1997); Mayan (2001); Debus (1994); Minayo (1994) e a própria Silva (1998); Valles (1997), diz que enquanto o quantitativo se ocupa de ordens de grandezas e de suas relações, o qualitativo se ocupa de interpretações ou compreensões daquilo que se pode medir ou quantificar.

Para Valles (1997), é inviável que um pesquisador se valha de mais de um paradigma, pois cada paradigma se conforma com um sistema de princípios. Por este motivo, alguns autores propuseram o termo perspectivas. Desse modo, “um paradigma pode englobar várias perspectivas teórico-metodológicas, além de ser caracterizado por uma série de princípios ou supostos gerais. E as perspectivas podem denominar-se também de paradigmas de rango inferior ou miniparadigmas” (PATTON, 1990, apud VALLES, 1997, p. 52). 
De acordo com Silva (1998), as verdadeiras oposições em pesquisa não estão entre a natureza qualitativa ou quantitativa, mas entre os paradigmas que embasam as práticas de pesquisa, isto é, nas visões de mundo subjacentes à essas práticas.

Podem existir ainda, potencialidades entre as articulações qualitativas e quantitativas havendo entre elas uma complementaridade, o que constitui na denominada triangulação metodológica (Mayan, 2001; Valles, 1997; Silva, 1998; Debus, 1994; e Minayo 1994). Nestes casos, uma investigação quantitativa pode conduzir o investigador à escolha de um problema particular a ser analisado em toda sua complexidade utilizando também, métodos e técnicas qualitativas e vice-versa, desde que se respeite a natureza da realidade investigada. Dessa maneira, qualitativo e quantitativo podem ser integrados numa mesma investigação tendo um encontro tanto em teorias como em métodos de análise e interpretação.

Na visão de Bruns (2003), a adoção de um ou de outro paradigma pelo pesquisador implica para ele, além de assumir procedimentos distintos em relação à adoção de um método, procedimentos distintos em relação à postura do pesquisador quanto às questões referentes à subjetividade, à objetividade, à neutralidade e à intersubjetividade, questões que se referem à própria visão de mundo que influenciou diferentes áreas como a Religião, a Sociologia, a Filosofia e a Psicologia.

É importante ressaltar que de acordo com Debus (1994), nem todos os temas ou fenômenos podem ser estudados por meio de métodos quantitativos e qualitativos, havendo além das razões conceituais, as quais caracterizam o que é uma investigação qualitativa e o que é uma investigação quantitativa, razões pragmáticas para que investigador opte por uma ou por outra investigação.

Tendo em vista a natureza do fenômeno que é: os significados que homens e mulheres atribuem à vivência da infidelidade amorosa do parceiro(a) e o como re- 


\section{significam suas relações amorosas com os(as) parceiros(as) após eles(elas) lhes terem}

sido infiéis, optamos por realizar uma investigação qualitativa.

Para Debus (1994), a principal razão conceitual para a realização de uma investigação qualitativa é a profundidade de resposta e de compreensão que esse tipo de investigação nos oferece e dentre algumas razões pragmáticas se encontram: a flexibilidade, pois o estudo pode se modificar caso seja necessário; a oportunidade, pois algumas técnicas podem ser utilizadas com rapidez; o custo, pois em geral uma investigação qualitativa é mais econômica do que uma investigação quantitativa; a não necessidade de instalações técnicas na área de realização da investigação, pois em geral esse tipo de investigação pode se realizar em áreas das quais não dispõem de grandes instalações eletrônicas como computadores ou máquinas; e o vínculo direto com a população estudada.

As investigações qualitativas se pautam numa visão paradigmática compreensivointerpretativa o que quer dizer que, em nosso caso, a compreensão e interpretação do fenômeno interrogado por nós só pode ser obtida por intermédio de interações intersubjetivas entre pesquisadora e colaboradores.

Com base nos autores apresentados nesse capítulo podemos apontar as características de uma investigação qualitativa, as quais se referem: (1) ao pesquisador como principal instrumento, pois os materiais registrados são revistos em sua totalidade por ele; (2) a importância vital dos significados atribuídos pelos colaboradores da pesquisa, pois os pesquisadores qualitativos se preocupam com as perspectivas dos colaboradores e com o diálogo entre pesquisador e colaboradores; (3) ao foco de interesse no processo da investigação e não em seus resultados ou produtos; isto é, no como as pessoas negociam os significados atribuídos ao fenômeno investigado ou no modo como diferentes pessoas dão sentidos às suas vidas; (4) a tendência da investigação de ser descritiva, pois os pesquisadores qualitativos tendem a realizar a análise em toda a sua riqueza, respeitando, tanto quanto 
possível, a forma em que os dados foram registrados ou transcritos; e (5) a tendência do pesquisador de realizar a análise de forma indutiva, o que quer dizer que o pesquisador qualitativo não tem o objetivo de confirmar ou afirmar hipóteses construídas previamente mas, ao invés disso, construir abstrações à medida em que os dados particulares recolhidos vão se agrupando. O pesquisador investigativo não presume que sabe suficientemente sobre o fenômeno que indaga para reconhecer as dimensões importantes dele antes de realizar a investigação.

Retomando Silva (1998, p. 171):

Da mesma forma que se pode encontrar estratégias clássicas, positivistas e quantitativistas de pesquisa que estejam realizando reduções extremadas a favor de um proclamado rigor científico, podemos encontrar estratégias qualitativas que realizando recortes ingênuos sem localizações históricas e contextuais, sejam tão alienadas e "metodolátricas" quanto as posturas positivistas que pretendem substituir ou suprir em sua deficiência.

Para Bruns (2003), a preocupação do pesquisador com a viabilidade de se realizar o processo de análise e com a credibilidade científica são elementos importantes no ato de pesquisar. Além disso, é importante ainda que haja motivação, disciplina, tempo e paixão por parte do pesquisador.

Com base nas afirmações destas autoras podemos dizer que é imprescindível que o pesquisador conheça as premissas das quais seu trabalho se baseia, compreendendo o que é um paradigma, o que é uma perspectiva e o que é um método.

Ao se tratar de investigação qualitativa é importante ainda que pesquisador tenha o cuidado de não fazer leituras apressadas, rápidas e sem fundamentação teórica adequada dos temas ao realizar o processo de análise, pois a qualidade de uma investigação qualitativa depende também de sua acuidade e interpretação.

Como vimos, um mesmo paradigma pode envolver várias perspectivas havendo, desse modo, diversas formas de investigações qualitativas. Dentre as várias perspectivas dentro de 
um mesmo paradigma podemos citar, por exemplo, a perspectiva fenomenológica, de matriz filosófica e a perspectiva psicanalítica, de matriz psicanalítica.

Ao retomarmos Valles (1997), observamos que também dentro uma perspectiva pode haver uma variedade de estilos e sub estilos de pesquisa, o que torna adequado tratar algumas perspectivas no plural. Encontramos dentro da perspectiva fenomenológica, por exemplo, os estilos próprios de Merleau-Ponty, de Paul Ricoeur, de Rezende, de Forghieri, de Amatuzzi, de Holanda, de Bruns, entre muitos outros; bem como encontramos dentro da perspectiva psicanalítica vários estilos que seguem diferentes escolas psicanalíticas, como as freudianas e as lacanianas, por exemplo.

Com base em nossa visão de mundo no momento histórico do qual vivemos e norteados pela natureza do fenômeno indagado que se refere aos significados que homens e mulheres atribuem à vivência da infidelidade amorosa do parceiro(a) e à re-significação da relação amorosa com os(as) parceiros(as) após estes(estas) lhes terem sido infiéis, utilizamos o método fenomenológico descritivo proposto pelo filósofo e fenomenólogo Rezende (1990), e submetemos os depoimentos dos(das) colaboradores(as) aos momentos da análise propostos por Giorgi (1978) e Bruns (2003). Situamos o fenômeno em sua temporalidade e em sua construção sócio-histórica-cultural e a partir dessa situcionalidade, buscamos compreende-lo à luz da perspectiva psicanalítica.

\subsection{A escolha pelo método}

Segundo Rezende (1990), a Fenomenologia só tem a ganhar dialogando com outras correntes teóricas como a filosofia analítica, a dialética materialista e a psicanálise, entre outras. Ao adentrar por um campo de investigação não mais filosófico em contato com as obras de Sigmund Freud, Jacques Lacan, Melanie Klein, Bion, entres outros, o autor 
questionou todo o seu projeto filosófico e passou a considerar que é possível haver pontos comuns entre a Fenomenologia e a Psicanálise.

Conhecer as dificuldades e os progressos de cada matriz disciplinar ou de cada perspectiva é importante para que o pesquisador opte pelo referencial teórico mais apropriado à natureza do fenômeno de sua investigação.

Nessa discussão é necessário compreender dois pólos que se dizem distintos: consciência e inconsciência, pois eles constituem a estrutura psíquica do indivíduo.

Para a Fenomenologia, atribuímos significados ao mundo e a nós mesmos por intermédio da consciência, a qual se denomina consciência intencional ou intencionalidade. Nessa visão, toda consciência é consciência de ou consciência para alguma coisa.

Nas palavras de Forghieri (2001, p.15):

A intencionalidade é, essencialmente, o ato de atribuir um sentido; é ela que unifica a consciência e o objeto, o sujeito e mundo. Com a intencionalidade há o reconhecimento de que o mundo não é pura exterioridade e o sujeito não é pura interioridade, mas a saída de si para um mundo que tem uma significação para ele.

Em outras palavras, não há consciência desvinculada de um mundo percebido e nem há mundo sem uma consciência para percebê-lo, o que quer dizer que, não há consciência pura, separada do mundo como afirmam os racionalistas, como não há objeto em si, independente de uma consciência que o perceba, como afirmam os empiristas. "Para a fenomenologia, o objeto é sempre para um sujeito que lhe atribui significados” (BRUNS, 2001, p.60).

Para Rezende (1990, p.34): “O fenômeno é como uma estrutura reuninda dialeticamente na intencionalidade, o homem e mundo, o sujeito e o objeto, a existência e a significação”.

Nessa ótica, a apreensão de uma determinada realidade, isto é, a busca pela essência de uma determinada realidade ou fenômeno só se dá a partir do sentido da realidade para uma 
subjetividade intencional e mais que isto, pela significação, pelos significados que alguém atribui a um determinado fenômeno.

Segundo Chauí (2001), a Filosofia Moderna inaugurou uma tarefa comum a todos os filósofos ao desenvolver a teoria do conhecimento, a reflexão filosófica: tornar o sujeito do conhecimento objeto de conhecimento para si mesmo. A teoria do conhecimento se baseia no pressuposto fundamental de que todos nós somos seres racionais e conscientes, sendo, a consciência, um conhecimento das coisas e de si; e sendo, a reflexão, um conhecimento desse conhecimento.

No entanto, apesar da subjetividade se manifestar plenamente como uma atividade que sabe de si mesma, não quer dizer que a consciência esteja sempre inteiramente alerta e atenta. Nessa ótica, há três graus de consciência: (1) a consciência passiva, na qual temos uma vaga e confusa percepção de nós mesmos e dos outros como no devaneio, no momento em que precede o sono ou o despertar, na anestesia ou na velhice, por exemplo; (2) A consciência vivida, mas não reflexiva, a qual é a nossa consciência afetiva que tem como peculiaridade ser egocêntrica, isto é, de perceber os outros e as coisas a partir de nossos sentimentos com relação a eles. Neste grau de consciência não conseguimos separar o eu e o outro, o eu e as coisas; (3) a consciência ativa e reflexiva, a qual reconhece a diferença entre o interior e o exterior, entre o si e os outros, entre o si e as coisas.

É este último grau de consciência, a consciência ativa e reflexiva, que é definido pela Fenomenologia como consciência intencional ou intencionalidade.

A Psicanálise por sua vez, introduz um componente novo à dinâmica psíquica, o inconsciente, o qual se trata segundo Chauí (2001), de algo do qual a consciência desconhece parcialmente. Mais que isso, esse algo desconhecido ou indiretamente conhecido determina para a Psicanálise tudo quanto a consciência e o sujeito sentem, fazem, dizem e pensam. Isto 
quer dizer que o sujeito do conhecimento descobre com a Psicanálise um limite intransponível, chamado inconsciente.

\begin{abstract}
A Psicanálise propõe mostrar que o Eu não somente não é senhor na sua própria casa, mas também está reduzido a contentar-se com informações raras e fragmentadas daquilo que se passa fora da consciência, no restante da vida psíquica... A divisão do psíquico num psíquico consciente e num psíquico inconsciente constitui a premissa fundamental da psicanálise, sem a qual ela seria incapaz de compreender os processos patológicos, tão freqüentes quanto graves, da vida psíquica e fazê-los entrar no quadro da ciência... A psicanálise se recusa a considerar a consciência como constituindo a essência da vida psíquica, mas nela vê apenas uma qualidade desta, podendo coexistir com outras qualidades e até mesmo faltar (FREUD, 1978 apud CHAUÍ, 2001, p. 166).
\end{abstract}

Na visão de Aranha e Martins (1986), a hipótese do inconsciente tornou-se fecunda, pois permitiu a compreensão de uma série de acontecimentos da vida psíquica.

Usando de uma metáfora, poderíamos dizer que a vida consciente é apenas a ponta de um iceberg, e a montanha submersa simboliza o inconsciente. Todos os nossos atos têm uma realidade exterior representada na nossa conduta e significados ocultos que podem ser interpretados (ARANHA \& MARTINS, 1986, p.195).

Com base nessa discussão, nos imbuímos pela idéia de que a vida psíquica se constitui por processos conscientes e inconscientes e desse modo, um diálogo entre a fenomenologia e a psicanálise se possibilita, sendo pertinente utilizarmos ambas perspectivas teóricas como perspectivas interpretativas.

Aranha e Martins (1986) também afirmam a possibilidade de se estabelecer uma aproximação entre essas duas escolas do saber, apesar de Sigmund Freud nunca ter se vinculado à Fenomenologia. Em uma análise fenomenológica, o fenômeno assume significado(s) e, por isso mesmo, necessita ser interpretado, o que também ocorre em uma análise psicanalítica.

Desse modo, um ponto comum entre a Fenomenologia e Psicanálise reside no fato de que as Ciências Humanas, ao considerar que o homem, o objeto de estudo dessas ciências é um ser histórico e cultural que produz os sentidos para a vida, para o mundo, para si próprio e tal sentido deve ser conhecido, utilizam-se de métodos de compreensão e interpretação. Seja 
qualquer perspectiva fenomenológica empregada numa investigação, bem como qualquer perspectiva psicanalítica, ambas fazem uso do paradigma interpretativo para compreender uma determinada realidade investigada.

Rezende (1990), estabelece uma distinção entre sentido próprio, sentido impróprio e sentido pleno da estrutura fenomenal de uma determinada realidade, após ter dialogado com as duas matrizes disciplinares, a Fenomenologia e a Psicanálise.

O sentido de um determinado fenômeno pode se manifestar de diversas maneiras, o que quer dizer que há diversos sentidos e que o símbolo nunca pode ser unívoco, é sempre polissêmico e como tal implica uma referência ao sentido pleno. O sentido próprio se refere àquele que se manifesta no interior de um tópico da estrutura fenomenal. No interior da estrutura simbólica se reconhece uma sinergia entre os diversos sentidos próprios, uma mútua referência que é uma alusão à plenitude do sentido do símbolo. O sentido impróprio se refere às diversas formas que manifestam a tendência do sentido a circular de um tópico para o outro, a deslocar-se, ou então a condensar-se numa antecipação da situação simbólica propriamente dita.

No sentido próprio, o símbolo é sentido pleno, isto é, a concentração do sentido em todos os sentidos. Contudo, em sua plenitude o sentido é inacessível, o que não significa que ele possa ser perdido de vista, pois ao contrário não seríamos nem capazes de reconhecer que o sentido impróprio é impróprio, que a metáfora é uma metáfora ou que a metonímia é uma metonímia.

A preocupação com o símbolo e a plenitude do sentido se traduz na dialética do tópico e do u-tópico. O sentido tópico permite a busca do sentido próprio do sentido e das idéias em seus respectivos lugares, na definição de espaços adequados de experiência e de discurso. Mas a percepção do sentido como tal implica também, a descoberta de que ele não é apenas a plenitude de uma estrutura dada, isto é, a somatória dos diversos sentidos numa determinada 
situação do mundo, pois ele é propriamente a plenitude do sentido na plenitude do mundo. Isto que dizer que a experiência que podemos fazer do sentido pleno é antes a de sua falta.

O sentido pleno é aquele que nunca encontramos e o qual, no entanto, nunca podemos renunciar. O senso do sentido que falta, isto é, do mais sentido que ainda há, é que dinamiza toda a nossa procura e relativiza todas as nossas descobertas.

Nessa ótica, Rezende (1990), diz que a ambigüidade da Fenomenologia significa a recusa de toda e qualquer forma de dogmatismo para permanecermos numa atitude de constante busca, que tanto caracteriza a existência como uma história, quanto nossa fala, como um discurso. A correspondência intencional a esta situação de falta do sentido pleno só pode ser vivida na forma de uma resposta que seja uma busca ininterrupta a respeito pelo que já foi descoberto e pela insatisfação com todos os substitutivos da plenitude simbólica.

Parece haver uma dicotomização entre a Psicanálise e a Fenomenologia por intermédio da crença de que qualquer evidência contida na verbalização estaria vindo da consciência da experiência, em oposição à crença de que o inconsciente se revela no discurso.

Contudo, não seria, pois mediado pela consciência que o que era inconsciente torna-se consciente? Não seria também o sujeito da falta, isto é, o sujeito da Psicanálise, aquele o qual atribui sentidos e significados às suas experiências, mas que, no entanto, não pode obter um discurso e um sentido pleno?

Concordamos com as idéias de Rezende (1990, p.18) de que:

O discurso fenomenológico pretende corresponder à encarnação do sentido em seus diversos lugares de manifestação, através da história. Uma palavra, uma frase, uma definição, nunca poderão dizer o que há a dizer. Temos necessariamente de recorrer ao discurso para nos aproximarmos o mais possível da densidade semântica do fenômeno humano.

Desse modo, embora atribuirmos significados à nossa vivência intencional, o significado pleno de uma determinada realidade nos é inalcançável, podendo o símbolo fazer 
apenas uma referência ao sentido pleno, posto que o sujeito do conhecimento é o sujeito da consciência e do inconsciente.

Para Rezende (1990), é pelo fato do fenômeno ser da ordem do símbolo e mais que isto, não ser unívoco, que o acesso a ele só pode se dar pelo caminho da interpretação, a qual consiste em desdobrar os níveis de significações implicados nas significações literais.

Na modalidade de pesquisa fenomenológica, o que buscamos é o acesso ao vivido. Não nos preocupamos nessa investigação, com as causas, com os porquês, muito menos com as conseqüências que a infidelidade amorosa do(da) parceiro(a) acarretam aos homens e mulheres entrevistados por nós. Buscamos os significados que estes(estas) atribuem a sua vivência.

Segundo Amatuzzi (2003), as pessoas nem sempre tiveram oportunidade de falar efetivamente de sua experiência, antes de colaborar com uma investigação e, se surpreendem freqüentemente com o que dizem, pois “o ‘vivido’ não é necessariamente ‘sabido’ de antemão. É no ato da relação pessoal, quando surge a oportunidade de dizê-lo, que ele é acessado. Diríamos que o vivido é surpreendido na relação, pela própria pessoa que então o comunica, facilitada pelo pesquisador” (AMATUZZI, 2003, p.19).

A pesquisa fenomenológica é, na visão desse autor, dialética, mobilizadora e profunda. Ela não tem sujeitos que forneçam informações, mas colaboradores que pensam junto ao pesquisador, como se fosse a primeira vez:

Colher informações já prontas normalmente é o objetivo de um questionário. $\mathrm{O}$ que se colhe é o passado. Mas surpreender o vivido no presente, quando a experiência da pessoa é pensada de repente e dita como pela primeira vez, isto é objetivo de uma entrevista fenomenológica (AMATUZZI, 2003, p.19).

Podemos traçar uma ponte entre o discurso de Amatuzzi (2003) quando ele diz que o vivido é surpreendido no aqui-e-agora, isto é, na intersubjetividade entre pesquisador e colaborador, e o discurso psicanalítico. 
Afinal o sujeito da Psicanálise é, em palavras distintas das ditas por Amatuzzi (2004), “aquele que diz, sem saber o que diz”, ou seja, a sua fala media o seu inconsciente. Além disso, na prática de investigação acadêmica, tão quanto ocorre na prática de investigação clínica, a fala tem um mediador. Em uma, ela é revelada pela pessoa do analista e, na outra, pela pessoa do pesquisador, sendo por essas questões que, assim como no campo clínico, no campo da pesquisa, o sujeito também se surpreende na própria ação de falar.

A pesquisa fenomenológica se dirige para as percepções ou significados que os sujeitos têm ou atribuem àquilo que esta sendo pesquisado e o pesquisador se preocupa, como já dissemos, com os significados que o fenômeno indagado têm para os colaboradores da pesquisa.

Vimos, entretanto, no decorrer desse capítulo, que, aquilo que o sujeito diz, não se refere somente à consciência, isto é, às percepções que ele tem sobre a sua vivência acerca de determinado fenômeno, já que muito do que ele fala, traz à tona conteúdos inconscientes, dos quais ele não imaginava saber.

Se para a Fenomenologia, as percepções do pesquisando ou do pesquisador se referem ao trabalho da consciência, isto é, à sua vivencia intencional, acrescentamos, com base no estudo de Rezende (1990), que o inconsciente faz também a sua parte e re-afirmamos que o significado pleno de uma determinada realidade nos é inalcançável.

Desse modo, se buscamos realizar um diálogo entre duas disciplinas que são, embora distintas, complementares, não é porque escolhemos referenciais teóricos que nos convêm, mas porque eles nos fornecem algumas respostas à nossa busca de compreensão do homem e de seu mundo, possibilitando-nos um engajamento de ser.

Nos dizeres de Nasio (1999, p. 142): “se uma teoria nos convém é porque temos com a teoria um ‘engajamento de ser’ e não um engajamento de pensamento”. 
Vale ainda ressaltar que, embora seja indiscutível a incidência do pensamento psicanalítico em qualquer questão que se refere ao psiquismo na vida contemporânea, contextualizada pelas transformações sócio-culturais atuais, de modo que no campo da pesquisa essa perspectiva tem cada vez mais ganhando forças, a Psicanálise ainda vem sofrendo algumas críticas por parte de alguns pesquisadores.

Para a maioria dos psicanalistas, o inconsciente e a interpretação psicanalítica podem existir somente no contexto da análise clínica, o que se dá por meio da relação transferencial. Segundo Garcia-Roza (1991), se a pesquisa acadêmica em psicanálise é criticada, de um lado por psicólogos, devido à irredutibilidade e especificidade contidas no discurso psicanalítico, de outro, é criticada pelos próprios psicanalistas, devido à pretensão de se submeter o discurso psicanalítico às regras do discurso acadêmico. Em sua perspectiva, se uma pesquisa é acadêmica, ela não pode ser psicanalítica, “poderia ser uma pesquisa sobre a psicanálise, mas não uma pesquisa em psicanálise. O verdadeiro laboratório de pesquisa é a pratica clínica fundada na transferência, e esta se passa no consultório e não nos campi universitários” (GARCIA-ROZA, 1991, p.12). Essa ótica considera então a possibilidade de realizar uma pesquisa científica sobre a psicanálise enquanto uma re-leitura da(s) teoria(s) psicanalítica(s), ou seja, propõe a tomada da Psicanálise da mesma forma que se toma uma teoria filosófica ou uma teoria científica a fim de verificar a sua lógica interna, a coesão estrutural de seus conceitos e as condições de suas possibilidades.

Na perspectiva de Hermann (1991), na análise, a interpretação é a operação do campo transferencial que visa produzir rupturas de campo. Esse autor distingue a interpretação daquilo que ele denomina de sentença interpretativa ou explicação, fazendo, esta última, referencia às forças racionais, isto é, à consciência, já que uma explicação passa necessariamente pela compreensão consciente, a qual, no caso da análise, obedece a um princípio de economia, diretivo e simples, que emprega a mesma linguagem do paciente. 
Para Hermman (1991), na análise, terapeuta deve:

Testar delicadamente pressões diferenciais exercidas em pontos diversos do tecido emocional, como os antigos clínicos palpando um abdômen, como músicos a afinar seu instrumento. Isto é a arte da interpretação: mais um dedilhar da alma alheia do que uma formulação pseudocientifica sobre o discurso do paciente. E que se consegue com isso? Mantemo-nos agarrados às prestações do desejo até que ele nos fale a verdade (HERMANN, 1991, p.90).

Corroborando com esta perspectiva, Nasio (1999, p.140) afirma que a interpretação é, entre todas as modalidades de ação do psicanalista, "a única intervenção capaz de provocar uma mudança estrutural na vida do analisando e, naturalmente, na vida da própria relação analítica”.

Desse modo, a interpretação se define, justamente, pelas condições nas quais ela se produz no analista, bem como pelos efeitos que ela gera no analisando. Logo, dois pontos são importantes: "os que marcam o aparecimento da interpretação no analista e os que marcam a acolhida, a recepção pelo analisando” (NASIO, 1999, p.142). Nessa cena, o silêncio do analisando é, sem dúvida, o sinal infalível do impacto de uma interpretação, no contexto clínico.

O inconsciente, nessa perspectiva se refere, então, a ordem de um saber que o sujeito veicula, mas ignora. Mas não é apenas um saber que leva o sujeito a dizer a palavra exata na hora exata, sem saber o que está dizendo, pois, é também o saber que ordena a repetição dessa mesma palavra, mais tarde, em outro lugar, fazendo girar o carrossel dos elementos passados ou futuros que, num dia ou em outro, ocuparam ou irão ocupar o lugar do significante manifesto.

Isso quer dizer que, sentimentos passados podem ser reativados a qualquer momento, no presente, sendo o inconsciente atemporal. 
O inconsciente é, também, um processo constantemente ativo, que não pára de se exteriorizar através de atos, acontecimentos ou palavras que reúnam as condições definidoras do significante, o qual é uma expressão involuntária, oportuna, e muitas vezes sem sentido aparente.

O inconsciente é um saber que não pode ser apreendido diretamente, é mais que uma hipótese, uma tese, um princípio ou um axioma: nós não podemos conhecê-lo ou apreendê-lo completamente! Ele é, pois, inapreensível e intangível, apesar de ser uma estrutura, a qual foi gerada quando Sigmund Freud fundou e nomeou o inconsciente, o que lhe concedeu uma existência e lhe deu consistência, obedecendo a lógica dos significantes.

Nasio (1999), afirma ainda que, é devido à concepção lógica de um inconsciente estendido entre dois sujeitos, uma das idéias fundamentais de Jacques Lacan, que devemos compreender que o inconsciente está fora do tempo, do espaço e da pessoa.

Desse modo, não é possível falarmos do inconsciente em termos de pessoa, nem em termos de passado, futuro ou presente, nem tampouco em termos de espaço-reservatório para designarmos o lugar do inconsciente.

A interpretação é ainda, na ótica de Nasio (1993), não uma expressão do inconsciente do analista, mas uma repetição que acontece hoje no dito ${ }^{1}$ do analista, de um sintoma que se manifestou ontem, no dito do analisando. Isto quer dizer que a interpretação formulada pelo analista atualiza o inconsciente do analisando, ou melhor, atualiza o inconsciente da análise. Assim, se o inconsciente é uma estrutura de significantes repetitivos que se atualizam num

${ }^{1} \mathrm{O}$ inconsciente é uma cadeia virtual de acontecimentos ou dizeres que sabem atualizar-se num dito oportuno, que o sujeito diz, sem saber o que está dizendo. O dizer é aquilo que foi ou será dito, mas que permanece inconsciente e o dito é o ato de enunciar um dizer e, que condensa em si, o conjunto da cadeia de dizeres inconscientes. Assim, o inconsciente é o dito que ao atualizar, quanto à ordem da estrutura, a cadeia que o constitui; é, ao mesmo tempo, o dito e o conjunto. Quando o dito surge no analisando, podemos o chamar de sintoma, lapso ou chiste e, quando surge no psicanalista, podemos chamar, dentre outras coisas, de interpretação (NASIO, 1993). 
dito enunciado por um ou por outro dos sujeitos analíticos, o inconsciente não pode ser individual. Não podemos atribuir um inconsciente próprio a um e um próprio ao outro. $\mathrm{O}$ inconsciente não é, então, nem individual, nem coletivo, mas produzido no espaço do entredois, como uma entidade única que atravessa e engloba os atores da análise.

Seguindo essa ótica, se o inconsciente existe, ele só pode existir no interior do campo da psicanálise, ou, mais precisamente, no interior do campo do tratamento analítico, pois, para que o inconsciente exista, é preciso que ele seja escutado e ainda reconhecido.

Dessa maneira, o inconsciente se revela num ato que surpreende e ultrapassa a intenção do analisando, que fala. O sujeito diz mais do que pretende e, ao dizer, revela sua verdade. Esse ato, mais que revelar um inconsciente oculto e já presente, produz o inconsciente e faz com que ele exista. O reconhecimento do inconsciente não é um reconhecimento do pensar, mas do ser. O psicanalista reconhece como ato o inconsciente do outro a partir de seu ser e de seu próprio inconsciente.

Para reconhecer que o ato do analisando é um colocar em prática o inconsciente, é preciso um outro ato, o do analista. Do ponto de vista que considera o inconsciente como uma estrutura, esses dois atos, o do analisando e o do analista, são formalmente idênticos ou significantes. Foi a partir desse exposto que Nasio (1993) formulou três hipóteses acerca do inconsciente:

(1) O inconsciente não é uma instância oculta, já presente, à espera de uma interpretação que venha revelá-lo, mas uma instância produzida quando a interpretação do analista, considerada como um ato de seu inconsciente, reconhece o ato do inconsciente do analisando. 
(2) Produzido, o inconsciente é uma estrutura única, comum a ambos parceiros analíticos. Não há um inconsciente pertencente a um e a outro, mas apenas um único inconsciente, produzido e singular no seio da transferência.

(3) Reafirmando sua proposta inicial de pensar a existência do inconsciente exclusivamente dentro da análise, Nasio (1993) afirma que o próprio Lacques Lacan se deteve sobre esse mesmo problema, sem resolvê-lo, dizendo que não há meios de saber se o inconsciente existe fora da psicanálise.

Nesse momento, tentaremos delinear que pesquisa é essa na qual buscamos a compreensão do fenômeno indagado ao submetermos as descrições dos(das) colaboradores(as) ao referencial teórico da Psicanálise. Trazer à luz os processos inconscientes que atravessam o ser humano está longe de ser uma tarefa simples e por isso fazemos uma indagação: “que análise (compreensão-interpretação) é essa que faremos, se não analisaremos sujeitos na prática clínica?”

Para Forghieri (2001, p.22), o conhecimento psicológico na prática clínica, “é reflexão e ao mesmo tempo vivência; é conhecimento que pretende descobrir a significação, no contato efetivo do psicólogo com sua própria vivência e com a de seus semelhantes”.

Retomando Garcia-Roza (1999), dizemos que ele afirma que na prática clínica a Psicanálise explora a potência significante, isto é, aquela potência que gera múltiplos sentidos. É pois, os sentidos acerca do fenômeno da infidelidade amorosa do(da) parceiro(a) que buscamos nessa investigação.

Contudo, embora Nasio (1993) reconheça a presença do inconsciente na prática clínica, ele afirma ainda que não podemos falar do inconsciente como se estivéssemos fora de seu alcance, pois toda linguagem é uma linguagem exposta a emergência dos efeitos do inconsciente, toda e qualquer fala é afetada pelo inconsciente. 
Com base nos argumentos apresentados por esses autores, podemos, entretanto, pontuar algumas semelhanças e algumas discrepâncias existentes nos encontros entre paciente-analista e pesquisador-colaborador.

Em ambos os casos há um enlace intersubjetivo, pelo qual a verdade, parcial, só pode ser acessada mediante uma figura mediadora, o analista ou o pesquisador. Podemos dizer também que a interpretação a qual nos referimos aqui é de outra ordem do qual é a interpretação formulada na clínica. De fato, a primeira, não produzirá mudança na vida dos(das) colaboradoras(es) interpretados, já que em um trabalho de pesquisa, não se encontram em análise. Eis por isso mesmo a nossa postura de respeito ético, por meio de um pedido formal de permissão para analisar as suas falas, antes de iniciarmos as entrevistas. $\mathrm{O}$ que difere uma prática da outra é o modo no qual se dá a interpretação. Assim como já afirmamos no decorrer deste trabalho que qualquer interpretação escapa ao sentido pleno de um determinado fenômeno, devido justamente ao trabalho do inconsciente, afirmamos também que, nenhuma interpretação na prática de pesquisa advém de aspectos somente inconscientes do pesquisador. Pelo contrário, afirmamos que os passos descritos por Girogi (1978) e Bruns (2003) na análise de pesquisa nos leva ao trabalho da consciência, a qual é mediada por aquilo que advém do inconsciente.

Podemos afirmar ainda que, assim como novos significados a respeito de uma determinada vivência são obtidos na prática clínica, qualquer que seja a clínica psicológica empreendida, pautada na Psicanálise ou em qualquer outra corrente teórica; novos significados também podem emergir com a prática acadêmica, seja com a socialização do saber construído ou mesmo no encontro intersubjetivo entre pesquisador-pesquisando, no aqui-e-agora, como nos colocou Amatuzzi (2003).

Afirmamos também que não realizamos uma pesquisa de cunho psicanalítico e, por isso, não entraremos no âmbito dos métodos psicanalíticos enquanto pesquisa científica. $\mathrm{O}$ 
que realizamos é uma investigação qualitativa, utilizando o método fenomenológico descrito por Rezende (1990), no qual utilizamos os passos de análises descritos por Giorgi (1978) e Bruns (2003) e submetemos as descrições dos(das) colaboradores(as) ao referencial teórico da Psicanálise a fim de compreendermos o fenômeno em sua co-existência com o ser humano, no mundo.

Embora a Psicanálise contenha métodos e técnicas próprios e irredutíveis de investigação clínica e aborde o sujeito predominantemente do ponto de vista dos arranjos e negociações subjetivas, ela não deixa de ser, ao nosso ver, um referencial capaz de oferecer não somente uma compreensão do psiquismo individual, mas também da vida social e cultural em suas múltiplas manifestações, nas práticas de pesquisa.

Desse modo, afirmamos que a análise (compreensão-interpretação) que realizamos, não se refere, sem dúvida, à interpretação psicanalítica tal como descrita na análise, mas à uma compreensão e interpretação que se dá pela apropriação de conceitos psicanalíticos, cujos autores nos oferecem subsídios para compreender e interpretar as vivencias dos(das) colaboradores(as) dessa investigação enquanto um ser situado no mundo, isto é, compreender as construções dos territórios existenciais que muitas vezes se constituem pelo esmagamento do desejo humano, numa transformação das referências de tempo e de espaço que ora impulsiona, ora restringe, ora paralisa o ser humano em seu universo existencial.

Quanto à questão que se refere à existência do inconsciente fora da experiência clínica fazemos a mesma indagação que os outros autores fizeram ao rememoramos os trabalhos de Nice da Silveira em “Imagens do Inconsciente”, (1982), quando a autora faz das obras de arte de pacientes psiquiátricos, uma leitura Iunguiana; e de Sérgio Telles, “O psicanalista vai ao cinema: artigos e ensaios sobre psicanálise e cinema”, (2004), quando o autor realiza uma análise psicanalítica de vinte e nove filmes e uma peça de teatro, por exemplos. 
Por fim, concluímos que nossa visão de mundo fez com que utilizássemos o método fenomenológico como caminho para desenvolver essa investigação, o que nos permitiu também, a possibilidade de não encararmos rupturas entre as perspectivas fenomenológica e psicanalítica no campo da pesquisa e, assim, viabilizar um diálogo entre as duas disciplinas, empregando a Fenomenologia enquanto método de pesquisa e a Psicanálise enquanto referencial interpretativo das descrições no momento de analisarmos os significados que homens e mulheres atribuem à vivência da infidelidade do(da) parceiro(a) e à resignificação de suas relações amorosas com estes(estas) após eles(elas) lhes terem sido infiéis.

A seguir, descreveremos o método de pesquisa.

\subsection{0 método}

\subsubsection{Acesso aos depoimentos: a entrevista fenomenológica descritiva}

Retomando o objetivo principal dessa pesquisa que é compreender quais significados homens e mulheres atribuem à vivência da infidelidade amorosa do parceiro(a) e como re-significam a relação amorosa após os(as) parceiros(parceiras) lhes terem sido infiéis utilizamos o método fenomenológico proposto por Rezende (1990) porque ele nos explicita os caminhos necessários para chegarmos a interpretação do fenômeno indagado.

Para realizar esse caminho utilizamos a entrevista descritiva e compreensiva a qual foi mediada pela questão: "Fale a respeito da sua relação afetiva e sexual no decorrer do seu casamento(namoro) e, em especial, após seu marido(esposa/namorada) lhe ter sido infiel”. Essa questão mobilizadora foi proposta a cada colaborador(a) de outras maneiras, até que ela fosse compreendida, tais como: "Fale para mim como era sua vida afetiva e sexual com o(a) 
seu(sua) marido(esposa/namorada) antes dele(a) lhe ter sido infiel. E como é agora?”; "Fale para mim o que significou para o Sr.(Sra.) ter sido traído(a)?”

É importante ainda informarmos ao leitor que, foram feitas intervenções da pesquisadora em momentos da entrevista em que os(as) colaboradores(as) se desviaram da questão indagada, bem como em momentos nos quais a pesquisadora não compreendeu claramente os relatos dos(das) colaboradores(as).

Com o intuito de garantir a qualidade científica dessa investigação, ancoramos no método que enfatiza que todo depoimento precisa apresentar seis características, as quais se relacionam entre si e que são expostas a seguir:

1. O depoimento ou descrição deve ser significante, enumerar todos e somente aqueles aspectos indispensáveis para que possamos compreender o determinado fenômeno. A descrição deve abranger ao máximo a riqueza de sentido(s) que envolve a existência humana em relação ao fenômeno. “A descrição tenta dizer em que sentido(s) há sentido(s). [...] Toda significação é significação de existência, e, por outro lado, a existência é significativa” (REZENDE, 1990, p.19). A descrição deve referir-se a existencialidade do fenômeno em relação à consciência perceptiva.

2. O depoimento ou descrição deve ser pertinente, não deve omitir nenhum dos aspectos que integram de fato a estrutura significativa do fenômeno, o qual "é sempre estruturado e, como tal, apresenta uma multiplicidade constitutiva” (REZENDE, 1990, p.21). A pertinência vem intensificar e explicitar a significância como sendo a da estrutura de um fenômeno específico e não de outro, sendo, ao contrário, impertinentes os aspectos não integrantes da estrutura fenomenal considerada. É preciso, neste caso, não correr o risco do reducionismo ou do fenomenismo: no primeiro, insistir em um aspecto em detrimento de outros, e no segundo, acumular toda e qualquer informação, 
sem discernimento fenomenológico, isto é, apontá-los sem serem significantes, pertinentes e relevantes.

3. O depoimento ou descrição deve ser relevante, deve ser potencialmente contextualizado de forma histórica e temporal. A relevância aponta para a concretude do fenômeno investigado, isto é, para sua presença no mundo. Enquanto a pertinência diz respeito à estrutura do fenômeno e a sua complexidade constitutiva, a relevância diz respeito à história do fenômeno.

Em nome da relevância é que a estrutura se reorganiza, e sua multiplicidade se unifica em função de uma ordem que não é abstrata e meramente conceitual, mas vivida, no contexto de uma situação existencial a partir da qual o sentido emergente em tal lugar deve necessariamente ser privilegiado e considerado como princípio de ordenação dos sentidos que se manifestam em outros lugares. (REZENDE, 1990, p. 22).

4. O depoimento ou descrição deve ser referente, deve se relacionar com a estrutura fenomenal e o seu contexto, ou seja, deve haver uma inter-relação entre os elementos que compõem o fenômeno, sua contextualização no mundo, no tempo e no espaço, o que oferece várias possibilidades de se perceber, descrever, compreender, interpretar e responder ao sentido. “[...] numa autêntica estrutura semântica, seus diversos aspectos têm uma significação própria que lhes vem da relação que se estabelece entre todos eles”. (REZENDE, 1990, p.23).

5. O depoimento ou descrição deve ser provocante, deve pôr em evidência o sentido como sentido para o sujeito de modo que este sujeito se sinta provocado a tomar uma direção dando sentido(s) a sua vivência em relação ao fenômeno indagado, o que pode acontecer de forma consciente e livre se envolvendo com os sentidos existentes, ou se alienando deles.

6. O depoimento ou descrição deve ser suficiente, o que não quer dizer que o discurso humano possa ser acabado, mas que precisa ser suficiente. Podemos dizer e re-dizer sem que tenhamos a impressão de que tudo foi dito, porque há mais sentido(s) do que 
possamos dizer. Contudo, devemos evitar a repetição compulsiva. Podemos ir ao máximo explicitando os sentidos(s) presentes na descrição, buscando até explicitar que sentido(s) poderiam ainda existir, mas devemos lembrar que o prosseguimento indefinido e exagerado do discurso pode levar a perda da inserção na realidade.

Ao eleger essas seis características, Rezende (1990), nos fornece os instrumentos necessários para olharmos a dimensão estrutural do fenômeno e delinearmos a sua estrutura, o que nos auxiliará em sua compreensão.

Após cada entrevista concluída transcrevemos na íntegra o depoimento de cada colaborador(a). Substituímos os nomes próprios de pessoas e de lugares por codinomes a fim de que a identidade dos colaboradores(as), bem como daquelas pessoas das quais eles(elas) citam em seus depoimentos sejam respeitadas e mantidas em sigilo.

Segundo Rezende (1990), um discurso suficiente permite a passagem para uma outra dimensão do discurso que é a busca da compreensão, embora a certeza de nunca a alcançá-la em sentido pleno, ou puro. Ao iniciarmos as transcrições das entrevistas, iniciamos o processo de passagem para a compreensão do fenômeno indagado, isto é, iniciamos a análise dos depoimentos dos(as) colaboradores(as) seguindo os quatro momentos de análise descritos por Giorgi (1978) e Bruns (2003):

\subsubsection{Momentos da análise dos depoimentos}

(1) Transcrição e leitura ampla de todos os depoimentos, sem buscar, ainda, qualquer interpretação do que está exposto ou sem qualquer tentativa de identificar qualquer atributo ou elemento contido. Esse momento tem a intenção de levar-nos à familiarização com a descrição da experiência vivida de cada colaborador(a) e à apreensão do significado e sentido geral atribuído por homens e mulheres à vivência 
da infidelidade conjugal e à re-significação da relação amorosa após a infidelidade do(a) parceiro(a).

(2) Releituras de cada depoimento a fim de evidenciar significados que são atribuídos pelos(as) colaboradores(as) à vivência do fenômeno indagado. Nesse momento ocorre a apreensão das Unidades de significado, as quais são extraídas dos depoimentos justamente em relação à perspectiva e à interrogação que dirigimos ao fenômeno.

(3) Agrupamento das Unidades de Significado em Categorias que expressam o insight psicológico contido nelas. Nesse momento, a linguagem coloquial do pesquisador é transformada no discurso psicológico, o que lhe exige a adoção de uma perspectiva teórica para analisar o fenômeno. É nesse momento que ao situarmos o fenômeno em sua temporalidade, utilizamos o referencial teórico da Psicanálise.

(4) Síntese e integração dos insights contidos em todas as Unidades de Significado, agrupadas em temas ou categorias em função das convergências e/ou divergências dos significados atribuídos pelos(as) colaboradores(as) e que constituem os aspectos essenciais da estrutura compreensiva geral do fenômeno, isto é, a sua essência ou os seus significados, interpretados de acordo com as perspectivas teóricas adotadas por nós.

A análise das Unidades de Significado com suas respectivas Categorias serão apresentadas no capítulo subseqüente. Antes disso, apresentamos a trajetória de acesso aos(as) colaboradores(as), as dificuldades encontradas neste percurso e os seus perfis. 


\subsubsection{Os(as) colaboradores(as)}

\section{Acesso aos (às) colaboradores (as) e as dificuldades encontradas no percurso}

Nossa trajetória de acesso aos colaboradores transcorreu por várias paragens.

$\mathbf{1}^{\mathbf{0}}$ momento: Inicialmente pretendíamos entrevistar 06 homens e 06 mulheres, heterossexuais, casados uma única vez, não entre si, pela Lei Civil e Igreja Católica e que foram traídos pelo(a) parceiro(a), pelo menos uma vez e continuaram unidos a ele(a) em matrimônio.

Buscávamos obter um grupo o mais homogêneo possível e por isso pretendíamos que a idade dos colaboradores variasse entre 35 e 45 anos, o tempo de casado de 02 a 27 anos, o grau de escolaridade entre o ensino fundamental incompleto e ensino superior completo, que o número de filhos fosse de 02 a 03 filhos, em média, e o nível econômico familiar fosse a média renda.

Como foi dito anteriormente, os nomes que citaremos a seguir são codinomes.

Ao iniciarmos a pesquisa, conversamos com várias pessoas de nosso meio pessoal e profissional a fim de divulgarmos a sua existência, seu objetivo, sua importância e justificativa social e científica, solicitando a cada uma dessas pessoas que nos auxiliasse na contatação dos colaboradores. Algumas delas se interessaram em nos ajudar e contatamos de início, por intermédio de nossa rede de contatos pessoais, duas mulheres. Uma delas, Isolda, foi entrevistada e a outra, ao ser re-contatada para o agendamento da entrevista, nos relatou o seguinte: "Não quero mais participar porque não quero mais falar disso [infidelidade do parceiro], quero esquecer”

Entramos em contato com duas clínicas privadas que oferecem atendimento psicológico, sendo a primeira uma clínica interdisciplinar na área da saúde e a segunda a “Clínica de Psicologia Aplicada” do Instituto de Ensino Superior Unificado de uma das 
unidades da Universidade Paulista - UNIP, numa cidade do interior paulista. Ambas clínicas nos autorizaram a contatar colaboradores dentre os seus clientes atendidos.

Por intermédio da primeira, contatamos e entrevistamos 03 mulheres: Bárbara, Stela e Verônica.

Na “Clínica de Psicologia Aplicada”, apenas duas estagiárias de psicologia realizavam atendimento à clientes cujo perfil atendia o objetivo dessa investigação. Uma das estagiárias, no entanto, recusou-se a abordar a sua cliente com o tema de nossa investigação: “Ah... ela não vai querer falar sobre isso [infidelidade do parceiro] com você” e nos disse sobre a sua preocupação em “nos abrir” o sigilo terapêutico. Explicamos a ela que teríamos acesso a identidade de sua cliente somente após esta tomar ciência da investigação e optar por colaborar conosco, o que seria feito pela própria estagiária de psicologia e não por nós. Mesmo após a explicação, a estagiária de psicologia se recusou em nos ajudar, disse-nos que a sua cliente se referia a um “caso complicado” do qual não poderia indagar sobre o desejo de participar dessa investigação.

A outra estagiária de psicologia nos ofereceu ajuda e consultou a sua cliente sobre o interesse em colaborar conosco. Após o consentimento desta, concedeu-nos o nome e o número do telefone pelo qual deveríamos fazer o contato com ela. Contudo, sua cliente nos pediu que telefonássemos entre os horários de 11:45 e 12:00 horas, na casa de sua cunhada, sendo nestes horários que poderíamos encontrá-la. Ao ter aceitado colaborar com a investigação, agendamos a data e o horário da entrevista na “Clínica de Psicologia Aplicada”. No entanto, a mulher não compareceu, não justificou a sua ausência e não conseguimos mais contatá-la via telefone.

No período de outubro de 2003, mês em que foi realizada a primeira entrevista, à junho de 2004, havíamos entrevistado apenas as três mulheres, citadas acima. Deparamo-nos com grandes dificuldades quanto a contatação dos colaboradores femininos e masculinos e 
por isso buscamos ampliar os nossos contatos. Contatamos alguns professores de um dos campi da Universidade Estadual Paulista - UNESP, e um dos Centros de Referência da Mulher de uma cidade do interior paulista. Estes centros são entidades municipais que oferecem atendimento psicológico gratuito a mulheres. Dentre as atendidas pelo centro, encontramos 06 mulheres que haviam vivenciado a infidelidade amorosa do parceiro, mas apenas 02 destas mulheres continuaram unidas aos cônjuges em matrimônio após a vivência da infidelidade, e uma outra havia se separado do parceiro e tentava uma reconciliação com este. Agendamos por duas vezes as entrevistas com as 02 mulheres casadas, mas elas não compareceram ao local de nosso encontro. Uma delas não justificou a sua falta, apenas nos disse via telefone, por duas vezes, que iria à entrevista, mas não comparecia. A outra mulher nos disse via telefone, que faltou ao primeiro agendamento, pois "tomava remédio antidepressivo e como estava sem os medicamentos que tomava, não poderia sair de casa”. Após o segundo agendamento e falta consecutiva dessa mulher, ela nos disse que não pôde comparecer, pois estava “cuidando do nenê de sua irmã, em sua própria casa”, o que a impedia de nos conceder a entrevista. Disse-nos que não poderia agendar uma nova data devido ao compromisso assumido com a irmã.

$2^{\mathbf{0}}$ momento: Diante das dificuldades encontradas em contatarmos homens e mulheres que se disponibilizassem em colaborar com essa investigação re-construímos a nossa estratégia de acesso em relação aos colaboradores. Optamos por entrevistar também mulheres que pudessem ter se separado dos parceiros e posteriormente se reconciliado com eles, e que poderiam ainda, não ter as idades ou o número de filhos dos quais havíamos proposto no início da investigação. Afinal, o acesso aos colaboradores mostrava-se restrito às nossas possibilidades. Entrevistamos Diva, contatada por intermédio do centro de referência da mulher, porém no momento de realização da análise percebemos que sua descrição não atendeu a algumas das características da entrevista descritiva apresentada por Rezende (1990). 
Por meio de nossos contatos pessoais, conhecemos e entrevistamos Flor-de-Liz, que havia se separado do parceiro e tentava uma reconciliação com ele. E entrevistamos também Nádia, cuja descrição também não foi condizente com os elementos da entrevista compreensiva de Rezende (1990) e por isto, não a analisamos.

Encontramos nesse momento, algumas mulheres que haviam se separado dos parceiros, mas optamos por entrevistar mulheres que continuaram casadas com os parceiros ou que se reconciliaram com estes após ter havido separação.

De outubro de 2003 a dezembro de 2005, não havíamos entrevistado nenhum homem. Por intermédio da clínica interdisciplinar já mencionada, 01 homem foi contatado, mas ele se recusou em nos falar sobre a sua experiência. Em conversas com colegas, obtínhamos conhecimento de alguns homens que tinham o perfil de um colaborador, mas os nossos contatos se recusavam a convidar os seus familiares, amigos ou colegas para colaborar conosco nessa investigação.

$3^{\mathbf{0}}$ momento: Ao encontrarmos tantas dificuldades em contatar colaboradores masculinos ampliamos ainda mais a rede de contatos e refazemos mais uma vez a nossa estratégia de ação modificando também a forma de acesso aos colaboradores. Buscamos auxílio em um Centro de Referência do Adulto, em uma cidade do interior paulista, que oferece atendimento psicológico gratuitamente a homens. Bem como os Centros de Referência da Mulher, estes também entidades municipais. Entre os atendidos por essa entidade, apenas 01 homem havia vivenciado a infidelidade amorosa da parceira, mas ele também não se dispôs a conceder-nos o seu depoimento sobre a sua vivência.

Nesse momento contatamos novamente nossos colegas, familiares e nossa rede de contatos profissionais dizendo eles que poderíamos receber um relato escrito sobre a experiência de homens que vivenciaram a infidelidade das esposas ou das namoradas, tendo ou não se separado destas após a vivência da infidelidade delas. Informamos ainda que a 
descrição escrita poderia ser enviada a nós via e-mail ou via correio, de modo que o colaborar não teria o contato pessoal com a pesquisadora.

Entramos ainda em contato, via e-mail, com outros profissionais que trabalham com a temática da sexualidade, como alguns profissionais associados à Sociedade Brasileira de Estudos em Sexualidade Humana -SBRASH, entidade civil multidisciplinar, sem fins lucrativos, fundada em 1986 e que tem por finalidade desenvolver o aprimoramento profissional e científico de estudiosos e profissionais ligados a àrea da sexualidade; como também com os profissionais cadastrados no cepcosonline@grupos.com.br, o Boletim Eletrônico do CEPCoS - "Centro de Estudos e Pesquisas em Comportamento e Sexualidade” afiliado à WAS - “World Association for Sexology” e à FLASSES - "Federación Latinoamericana de Sociedades de Sexolologia y Educación Sexual”. Estes últimos se referem à cerca de 8.697 profissionais ligados à temática da sexualidade.

Contudo, foram encaminhados à nós apenas 04 depoimentos masculinos, três via email e um entregue em mãos. Curiosamente, embora ter ampliado a nossa rede de contatos profissionais, os 04 depoimentos foram obtidos por intermédio de nossa rede de contato pessoal, o que nos leva a crer que a confiança e a proximidade entre aquele que contata e o colaborador parece ser um facilitador na obtenção de colaboradores para uma investigação.

Ao receber os depoimentos escritos, deparamo-nos, entretanto, com discursos empobrecidos acerca das experiências vividas. Estas descrições não atendiam as características do método formulado por Rezende (1990) e por isto foram descartadas e a partir desse momento, desistimos de obter os depoimentos por escrito.

$4^{\mathbf{0}}$ momento: Entramos em contato via correio eletrônico com os homens que relataram a vivência por escrito e um deles, Romeu, que se separou da namorada após a infidelidade amorosa dela, se disponibilizou a conceder-nos o seu depoimento em um encontro com a pesquisadora. Contatamos novamente nossa rede de apoio e por intermédio de 
amigos mais íntimos conseguimos contatar e entrevistar mais 04 colaboradores masculinos: Paris que foi casado pela Lei Civil e pela religião católica e se separou da esposa após esta lhe ter sido infiel; Aquiles, solteiro, assim como Romeu, que se separou da namorada após ela lhes ter sido infiel; e Ulisses que foi casado pelo contrato de conjunção marital e também se separou da parceira após a vivência da infidelidade dela.

Faz-se necessário informar nosso leitor que, depois de ter sido realizado o convite a cada colaborador(a) e após cada um(uma) deles(delas) ter aceito participar da pesquisa, agendamos a entrevista em local, data e horário de acordo com a disponibilidade de cada um(a) deles(as). Entrevistamos Isolda na casa da própria pesquisadora; Bárbara e Stela na clínica interdisciplinar; Ulisses, Aquiles e Páris em uma outra clínica; Romeu e Verônica, em seus respectivos locais de trabalho e Flor-de-Liz, em sua casa.

Antes de iniciarmos as entrevistas, cada colaborador(a) assinou o Termo de Consentimento Livre e Esclarecido (anexo B), elaborado de acordo com a Resolução $\mathrm{n}^{\circ}$ 196/96 sobre Pesquisa envolvendo seres humanos do Conselho Nacional de Saúde Ministério da Saúde - Brasília, Distrito Federal, e aprovado pelo Comitê de Ética em Pesquisa da Faculdade de Filosofia, Ciências e Letras de Ribeirão Preto - USP (anexo A). O Termo de Consentimento Livre e Esclarecido contém informações sobre a natureza da pesquisa, seus objetivos, sua importância científica e social, seu método, a preservação da identidade do(a) colaborador(a), os benefícios previstos e os incômodos que a investigação possa acarretar à eles(as) e a informação de que caso queiram retirar seus consentimentos após a descrição devem ser respeitados(as) nessa decisão sem que ocorra qualquer dano ou prejuízo à suas pessoas. O termo de consentimento contém também o perfil dos(as) colaboradores(as). Como o perfil almejado foi modificado em virtude das dificuldades encontradas para contatarmos colaboradores(as), alteramos o termo de consentimento no que se refere ao perfil dos colaboradores, dizendo que entrevistaríamos homens que tivessem se separado das esposas 
após a vivência da infidelidade amorosa destas ou homens que tivessem vivenciado a infidelidade amorosa das namoradas. Além disso, optamos por modificar o perfil no que se referia à idade dos colaboradores e ao número de filhos esperado, pois entrevistamos mulheres com idades superiores e homens com idades inferiores àquelas as quais havíamos estipulado, bem como homens que não tiveram filhos. A assinatura do termo de consentimento pelo colaborador(a) visa a comprovação de sua anuência à pesquisa e após obter todas as informações necessárias e é datado e assinado por ele(ela) e também pela pesquisadora, a qual se responsabiliza pelas informações contidas no termo, ficando uma cópia para o(a) colaborador(a) e uma cópia para a pesquisadora. É importante que o(a) colaborador(a) compreenda a respeito da importância de sua entrevista para que se sinta seguro(a) e se solte ao fluxo de sua vivência relatando-a de forma clara e autêntica. Depois de assinado e datado o termo de consentimento, cada colaborador(a) respondeu a algumas questões que visaram classificar o perfil de cada um deles(as) em relação a idade, religião, grau de instrução, área de atuação, bem como dados conjugais (anexo C) e, em relação a classificação econômica (anexo D). Em seguida, realizamos a entrevista.

Este estudo se constitui de 9 colaboradores, sendo 05 mulheres e 04 homens. Apresentaremos, a seguir, o perfil dos (das) colaboradores (as). 
Tabela 1 - A idade de cada colaborador (a) e de seu respectivo (ex) parceiro (a) e o nível econômico da família:

\begin{tabular}{|l|l|l|l|l|}
\hline COLABORADOR (A) & IDADE & $\begin{array}{l}\text { IDADE DO (A) (EX) } \\
\text { PARCEIRO (A) }\end{array}$ & $\begin{array}{l}\text { ESTADO CIVIL } \\
\text { ATUAL }\end{array}$ & $\begin{array}{l}\text { CLASSE } \\
\text { ECONÔMICA } \\
\text { FAMILIAR }^{*}\end{array}$ \\
\hline ISOLDA & 42 anos & 36 anos & Casada & Casada \\
\hline BÁRBARA & 54 anos & 57 anos & Casada & B1 \\
\hline STELA & 47 anos & 53 anos & Casada em & B1 \\
\hline VERÔNICA & 59 anos & 53 anos & $\begin{array}{l}\text { Separada } \\
\text { reconciliação }\end{array}$ \\
\hline FLOR DE LIZ & 45 anos & 47 anos & $\begin{array}{l}\text { Separado namorando } \\
\text { outra parceira }\end{array}$ & B1 \\
\hline ULISSES & 34 anos & 37 anos & $\begin{array}{l}\text { Solteiro } \\
\text { outra parceira }\end{array}$ & A2 \\
\hline ROMEU & 34 anos & 32 anos & Separado & C \\
\hline AQUILES & 31 anos & 29 anos & 32 anos & \\
\hline PÁRIS & 33 anos & & \\
\hline
\end{tabular}

Fonte: Elaboração própria.

Tabela 2 - A escolaridade e a área de atuação de cada colaborador (a) e de seu respectivo (ex) parceiro (a):

\begin{tabular}{|l|l|l|l|l|}
\hline COLABORADOR (A) & ESCOLARIDADE & $\begin{array}{l}\text { ESCOLARIDADE DO ÁREA DE ATUAÇÃO } \\
\text { (A) EX PARCEIRO (A) }\end{array}$ & $\begin{array}{l}\text { ÁEA ATUAÇÃO } \\
\text { ATO } \\
\text { (DA) } \\
\text { PARCEIRO (A) }\end{array}$ \\
\hline ISOLDA & $\begin{array}{l}\text { Ensino superior } \\
\text { completo }\end{array}$ & Ensino médio completo & Educação & Telecomunicação \\
\hline BÁRBARA & $\begin{array}{l}\text { Ensino médio } \\
\text { completo }\end{array}$ & $\begin{array}{l}\text { Ensino médio } \\
\text { incompleto }\end{array}$ & Dona-de-casa & Aposentado \\
\hline STELA & $\begin{array}{l}\text { Ensino fundamental } \\
\text { incompleto }\end{array}$ & $\begin{array}{l}\text { Ensino fundamental } \\
\text { incompleto }\end{array}$ & Dona-de-casa & Aposentado \\
\hline VERÔNICA & $\begin{array}{l}\text { Ensino superior } \\
\text { completo }\end{array}$ & Pós-doutoramento & Saúde & Educação \\
\hline FLOR DE LIZ & $\begin{array}{l}\text { Ensino superior } \\
\text { completo }\end{array}$ & Ensino médio completo & Educação & Finanças \\
\hline ULISSES & $\begin{array}{l}\text { Ensino superior } \\
\text { completo }\end{array}$ & $\begin{array}{l}\text { Ensino superior completo } \\
\text { completo }\end{array}$ & Engenharia & Secretariado \\
\hline ROMEU & Pós-graduação & Pós-graduação incompleto & Educação & Dona-de-casa \\
\hline AQUILES & $\begin{array}{l}\text { Ensino superior } \\
\text { Incompleto }\end{array}$ & $\begin{array}{l}\text { Ensino médio } \\
\text { incompleto }\end{array}$ & Informática & Secretariado \\
\hline PÁRIS & Ensincaca & Jurídica completo \\
\hline
\end{tabular}

Fonte: Elaboração própria.

\footnotetext{
* De acordo com o Critério de classificação econômica-Brasil elaborado pela Associação nacional de empresas de pesquisa dados - ANEP- com base no levantamento sócio-econômico - 2000-IBOPE
} 
Tabela 3 - A religião de cada colaborador (a) e de seu respectivo (ex) parceiro (a), o número de filhos (as) do casal, a idade e o sexo deles (as):

\begin{tabular}{|l|l|l|l|l|}
\hline COLABORADOR (A) & RELIGIÃO & $\begin{array}{l}\text { RELIGIÃO DO (A) } \\
\text { (EX) PARCEIRO (A) }\end{array}$ & $\begin{array}{l}\text { NÚERO DE FILHOS } \\
\text { (AS) }\end{array}$ & $\begin{array}{l}\text { IDADE DOS FILHOS } \\
\text { (AS) E SEXO }\end{array}$ \\
\hline ISOLDA & Católica & Católica & 02 & $\begin{array}{l}09 \text { anos }-\mathrm{M} \\
10 \text { anos }-\mathrm{M}\end{array}$ \\
\hline BÁRBARA & Católica & Católica & 03 & $\begin{array}{l}33 \text { anos }-\mathrm{F} \\
28 \text { anos }-\mathrm{M} \\
27 \text { anos }-\mathrm{F}\end{array}$ \\
\hline STELA & Católica & Ateu & 03 & $\begin{array}{l}27 \text { anos }-\mathrm{F} \\
18 \text { anos }-\mathrm{M} \\
15 \text { anos }-\mathrm{M}\end{array}$ \\
\hline VERÔNICA & Católica & Católica & 02 & $\begin{array}{l}28 \text { anos }-\mathrm{M} \\
26 \text { anos }-\mathrm{F}\end{array}$ \\
\hline FLOR DE LIZ & Católica & Católica & 02 & $\begin{array}{l}25 \text { anos -F } \\
21 \text { anos -M }\end{array}$ \\
\hline ULISSES & Espírita & Atéia & - & - \\
\hline ROMEU & Católica & Espírita & - & - \\
\hline AQUILES & Católica & Batista & - & 10 amos - M \\
\hline PÁRIS & Católica & Espírita & 01 & \\
\hline
\end{tabular}

Fonte: Elaboração própria.

Tabela 4 - O tipo e o tempo de união de cada colaborador (a) com seu respectivo (ex) parceiro (a) e o tipo de separação e/ou de reconciliação daqueles que se separaram dos parceiros (as) após a infidelidade amorosa destes (as):

\begin{tabular}{|c|c|c|c|c|}
\hline COLABORADOR(A) & TIPO DE UNIÃO & TEMPO DE UNIÃO & $\begin{array}{l}\text { TIPO } \quad \text { DE } \\
\text { SEPARAÇÃO }\end{array}$ & $\begin{array}{l}\text { TIPO DE } \\
\text { RECONCILIAÇÃO }\end{array}$ \\
\hline ISOLDA & Civil e religioso & 12 anos casada & 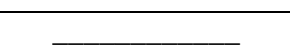 & \\
\hline BÁRBARA & Civil e religioso & 34 anos casada & 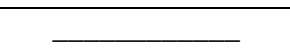 & \\
\hline STELA & Civil e religioso & 29 anos casada & & \\
\hline VERÔNICA & Civil e religioso & 29 anos casada & 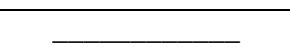 & + \\
\hline FLOR DE LIZ & Civil e religioso & $\begin{array}{l}24 \text { anos casada no civil } \\
06 \text { anos casada religioso } \\
02 \text { anos separada } \\
06 \quad \text { meses } \\
\text { reconciliação }\end{array}$ & Separação judicial & $\begin{array}{l}\text { Reconciliação morando } \\
\text { em casas separadas }\end{array}$ \\
\hline ULISSES & Conjunção marital & 05 anos casado & $\begin{array}{l}\text { Dissolução de } \\
\text { conjunção marital }\end{array}$ & Não \\
\hline ROMEU & Namoro & 03 anos namoro & Término namoro & Não \\
\hline AQUILES & Namoro & 03 anos namoro & Término namoro & Não \\
\hline PÁRIS & Civil e religioso & 07 anos casado & Separação judicial & Não \\
\hline
\end{tabular}

Fonte: Elaboração própria.

Após delineado os perfis dos(das) colaboradores(as) dessa investigação, passaremos ao próximo capítulo, no qual será apresentado as Categorias e Subcategorias encontradas nas descrições dos(das) colaboradores(as), com a devida análise. 


\section{CAPÍTULO 4 - O TEMPORALIZAR DA INFIDELIDADE AMOROSA PELAS VOZES FEMININAS E MASCULINAS}

“A porta da verdade estava aberta, mas só deixava passar meia pessoa de cada vez. Assim não era possível atingir toda a verdade, porque a meia pessoa que entrava só trazia o perfil da meia verdade.

E sua segunda metade voltava igualmente com meio perfil.

E os meios perfis não coincidiam. Arrebentaram a porta. Derrubaram a porta. Chegaram ao lugar luminoso onde a verdade esplendia seus fogos. Era dividida em metades diferentes uma da outra. Chegou-se a discutir qual a metade mais bela. Nenhuma das duas era totalmente bela.

E carecia optar. Cada um optou conforme seu capricho, sua ilusão, sua miopia”.

Carlos Drumond de Andrade

Este capítulo apresenta a análise, isto é, a compreensão e interpretação das descrições dos(das) colaboradores(as) acerca do fenômeno dos significados que homens e mulheres atribuem à vivência da infidelidade amorosa do(a) parceiro(a) e à re-significação da relação amorosa após essa experiência.

Ao nos aproximarmos deste fenômeno por intermédio da metodologia qualitativa, que descrevemos no capítulo anterior, a partir dos depoimentos de 09 colaboradores, 05 mulheres e 04 homens, pudemos categorizar e subcategorizar algumas dimensões do fenômeno. 
A fala do homem, entretanto, é mediada por conteúdos conscientes e inconscientes, que inundados pela temporalidade humana, trazem a verdade interior de cada um.

Para Heidegger (1971), a temporalidade é o fundamento básico da existência humana e constitui o sentido originário do existir. Porém, o ser humano nunca poderá se completar ou se totalizar em sua existência, pois o ser total só é possível através da morte.

Segundo Berenstein (1988), quando descrevemos a nossa história, relatamos conscientemente alguns acontecimentos passados importantes e gravados na memória, mas esquecemos outros, e ocultamos alguns, que são possivelmente não menos importantes ou significativos. Isto quer dizer que o tempo individual e, mais que isto, o tempo familiar, é organizado de acordo com uma estrutura inconsciente, capaz de se transformar em um marco onde se colocam não somente os acontecimentos vividos, mas também a relação entre estes acontecimentos quanto ao passado, ao presente e ao futuro.

Existe um tempo quando os episódios são vividos, e outro, em que são lembrados e agrupados a partir do presente; uma atividade nem sempre consciente. Assim, os acontecimentos, que despertam vergonha e são indesejáveis para um indivíduo ou para uma família, podem ser apagados da consciência ou conservados em outro tempo, com um significado diferente do original. Podemos, pois, esmaecer acontecimentos significativos, reavivar fatos pouco significativos ou mesmo acrescentar outros fatos não ocorridos para dar coerência à história que contamos, à nossa existência.

A temporalidade, na ótica do psicanalista Berenstein (1988), faz referência a um tempo inconsciente, não evolutivo, não reversível: o tempo da significação. Esse tempo contém elementos de significação que são sempre atuais. Desse modo, o tempo inconsciente mantém em uma mesma estrutura acontecimentos ocorridos em épocas diferentes, que são agrupados em um modelo regulador de sentidos permanentemente presentes. 
Na visão de Forghieri (2001, p. 42-43), vivenciamos o tempo em nosso existir quotidiano:

como uma totalidade, que consiste num presente perene, abarcador, tanto do já acontecido como do que esperamos que venha a acontecer. Costumamos experienciar o nosso existir como um fluxo contínuo, decorrendo numa "velocidade" e intensidade que se alteram de acordo com a nossa maneira de vivenciar as situações, que é sempre acompanhada de algum sentimento de agrado ou desagrado. Os instantes vivenciados com sintonia e contentamento decorrem rapidamente, enquanto os momentos de preocupação, contrariedade, ou tédio, decorrem devagar. Tais alterações acontecem apenas em nosso temporalizar, não interferindo no tempo marcado pelo relógio, pois neste os instantes mantêm, sempre, a mesma duração. Por isso, podemos vivenciar horas como se fossem minutos e, inversamente, minutos como se fossem horas.

A perspectiva desta fenomenológica considera que vivenciamos a velocidade e a extensibilidade do tempo em nosso existir, ao mesmo tempo, tanto em relação ao passado, quanto em relação ao futuro, de modo que a experiência de sintonia e contentamento é expandidora do nosso temporalizar, enquanto que a vivência de preocupação e contrariedade é a sua restringidora.

Nos dizeres de Forghieri (2001, p.52):

O nosso existir é realmente cheio de incertezas, pois decorre num fluxo crivado de paradoxos e de riscos que nos dificultam ter segurança para agir. A insegurança permanece mesmo quando procuramos nos apoiar nas experiências passadas, agindo em termos do que já conhecemos, pois, o presente também é abertura para o futuro e este sempre contem imprevistos, que, tanto, nos aparecem em agradáveis surpresas, como em tristes desapontamentos e, algumas vezes, até em infortúnios que podem nos abalar e transformar, profundamente, a nossa vida.

Enquanto Lipovetsky (2004) compreende a angústia vivida pelo homem contemporâneo como reflexo de uma cultura paradoxal, a ótica de Forghieri (2001) considera a pura e simples existencial do ser humano no mundo como uma condição sinequanon para vivenciar conflitos e paradoxos. 
Nessa perspectiva, a própria abertura originária do ser humano as suas múltiplas possibilidades de existir e as suas restrições evidenciam o quanto a existência humana somadas por pólos que se opõem e que constituem de fato a totalidade de nossa vida cotidiana é paradoxal.

Portanto, a vivência da infidelidade amorosa envolve o temporalizar interno, permeado por conteúdos conscientes e inconscientes, bem como pelos paradoxos de nossa própria existência. Embora reflita na realidade o ethos dos valores de uma determinada cultura individual e familiar, em sua sociedade e época, ela se faz para o homem em uma temporalidade que não segue o tempo cronológico, mas que regula os atos e os pensamentos significativos, ora expandindo, ora restringindo a vivencia do tempo e do espaço. Esta vivência é capaz de levar o homem a perder as referências de sua própria identidade, a modificar-se e, por várias vezes, o leva a re-significar a sua trajetória existencial, como veremos no decorrer deste capítulo nas descrições dos(das) colaboradores(as) dessa investigação.

Entretanto, ao indagarmos sobre o significado da vivência da infidelidade amorosa do(da) parceiro(a) e da re-significação da relação dual após a sua ocorrência, por homens e mulheres, numa existência na qual o temporalizar não segue uma ordem cronológica, mas uma ordem de significados conscientes ou não, somos levadas a assumir uma determinada postura: dar uma coerência às falas dos homens e mulheres entrevistados mediante a ordenação destas falas em categorias, que foram compostas por meio de leituras e releituras de todas as descrições, a fim de que se tornassem inteligíveis para a análise. Tais significados relacionam-se entre si e transmitem valores, sentimentos e comportamentos de uma estrutura psíquica familiar específica e também da própria sociedade como um todo, ou seja, numa relação dialética entre homem e mundo. 
Um dos momentos da análise, como já dissemos, refere-se à compreensão e interpretação das descrições dos(das) colaboradores(as) por meio da sua submissão ao referencial teórico de autores psicanalíticos.

A Psicanálise aborda o indivíduo predominantemente do ponto de vista da rede de arranjos e negociações subjetivas. Posto que essas negociações existem sempre em relação a algo ou alguém, isso nos possibilita situar o ser humano enquanto um ser-no-mundo, fadado à construção e à transmissão psíquica de valores, sentimentos e comportamentos existentes em sua família de origem e na de seus ancestrais, bem como em sua sociedade, estando sempre afetando e se deixando afetar pelo universo.

Assim, depois de submetermos as descrições dos(das) colaboradores(as) aos momentos da análise tais como explicitamos no Capítulo 3, apresentaremos nesse momento, as categorias e subcategorias obtidas nessa trajetória.

\subsection{Categorias e subcategorias emergidas das descrições femininas.}

Categoria 1. Adolescência, juventude e namoro: a transição para a vida adulta. As Unidades de Significado referentes a essa categoria foram encontradas nas descrições de Isolda, Bárbara, Stela e Flor de Liz.

\section{Categoria 2. Casamento: encantos e desencantos.}

- A relação afetiva e sexual antes da vivência da infidelidade do parceiro.

As Unidades de Significado referentes a essa subcategoria foram encontradas nas descrições de Isolda, Bárbara, Flor de Liz e Verônica.

- Gravidez e infidelidade: os conflitos vividos com a chegada do bebê.

As Unidades de Significado referentes a essa subcategoria foram encontradas nas descrições de Isolda, Stela e Flor de Liz.

- Amor, dor e luto: perspectivas femininas. 
As Unidades de Significado referentes a essa subcategoria foram encontradas nas descrições de Isolda, Bárbara, Stela e Flor de Liz.

- A dinâmica da infidelidade e os filhos.

As Unidades de Significado referentes a essa subcategoria foram encontradas nas descrições de Bárbara, Stela, Flor de Liz e Verônica.

- Ciúme e violência: a tragédia amorosa.

As Unidades de Significado referentes a essa subcategoria foram encontradas somente na descrição de Stela.

Categoria 3. A re-significação do relacionamento amoroso: reconstrução do prazer e/ou aprisionamento da dor.

As Unidades de Significado referentes a essa categoria foram encontradas nas descrições de Isolda, Bárbara, Stela, Flor de Liz e Verônica.

\subsection{Categorias e subcategorias emergidas das descrições masculinas.}

Categoria 1. Adolescência, juventude e namoro: a transição para a vida adulta. As Unidades de Significado referentes a essa categoria foram encontradas somente na descrição de Páris.

\section{Categoria 2. Parceria: encantos e desencantos.}

- A relação afetiva e sexual antes da vivência da infidelidade da parceira.

As Unidades de Significado referentes a essa subcategoria foram encontradas nas descrições de Romeu, Ulisses, Aquiles e Páris.

- Amor, dor e luto: perspectivas masculinas.

As Unidades de Significado referentes a essa subcategoria foram encontradas nas descrições de Romeu, Ulisses, Aquiles e Páris. 


\section{- A dinâmica da infidelidade e os filhos.}

As Unidades de Significado referentes a essa subcategoria foram encontradas somente na descrição de Páris.

- Ciúme e violência: a tragédia amorosa.

As Unidades de Significado referentes a essa subcategoria foram encontradas somente na descrição de Romeu.

\section{Categoria 3. A re-significação do relacionamento amoroso na perspectiva}

\section{masculina.}

As Unidades de Significado referentes a essa categoria foram encontradas nas descrições de Romeu, Ulisses, Aquiles e Páris.

Optamos por apresentar inicialmente as descrições das colaboradoras e depois as descrições dos colaboradores, apresentando o perfil de cada um(a) deles(as), seguidos da compreensão e interpretação de suas descrições, na seqüência de categorias e subcategorias emergidas e que estarão em negrito, a fim de facilitar a compreensão do leitor. 


\subsection{O temporalizar da infidelidade amorosa pelas vozes femininas.}

"Se ela me deixou, a dor é minha só, não é de mais ninguém.

Aos outros eu devolvo a dó,

Eu tenho a minha dor.

Se ela preferiu ficar sozinha, ou já tem um outro bem.

Se ela me deixou a dor é minha, a dor é de quem tem.

É meu troféu, é o que restou, é o que me aquece sem me dar calor.

Se eu não tenho o meu amor, eu tenho a minha dor. A sala, o quarto, a casa está vazia, a cozinha, o corredor. Se nos meus braços ela não se aninha, a dor é minha.

É o meu lençol, é o cobertor, É o que me aquece sem me dar calor.

Se eu não tenho o meu amor eu tenho a minha dor (...)”.

Marisa Monte e Arnaldo Antunes 


\section{ISOLDA}

Entrevista realizada em 01 de Outubro de 2003.

Isolda tem 42 anos e seu parceiro tem 36, é casada há 12 anos, no civil e no religioso, casou-se aos 30 anos e seu marido aos 24. A religião do casal é católica e o nível econômico da família corresponde à classe B1. Eles têm dois filhos com idades de 09 e 10 anos. Isolda possui ensino superior completo e Tristão, seu marido, possui ensino médio completo. Ela trabalha na área da educação e ele na área da telecomunicação. Foi durante o período pós-natal da primeira gravidez do casal, há 10 anos, que Isolda teve conhecimento de que seu marido lhe era infiel. Na ocasião da entrevista, Tristão estava desempregado há um ano aproximadamente, as crises financeiras abalavam a estrutura emocional do casal e foi quando Isolda demonstrou forte sentimento de vingar-se das infidelidades do marido, desejando lhe ser infiel também.

Em sua descrição Isolda revela que em sua adolescência e juventude tivera vários namorados antes de namorar e se casar com Tristão e faz uma comparação entre suas vivências afetivas e sexuais e as de seu parceiro, vividas antes do casamento, como vemos no relato abaixo:

Eu sempre colocava ele [parceiro] assim... como meio inexperiente por ele não ter tido muitas experiências na vida, 'né? Antes da gente se casar ele só teve duas pessoas, 'né? a primeira pessoa que ele teve na vida também foi com uma pessoa mais velha que ele, e depois ele ficou noivo cinco anos e já logo que ele terminou, depois de alguns meses, ele me encontrou, a gente começou a namorar, tudo, e depois acabâmo casando. Então, ele não teve muitas experiências. Eu já tinha tido mais experiências do que ele. 
Percebemos que a colaboradora afirma uma possível “inexperiência” do marido em relação as suas próprias experiências afetivas e sexuais. Inserida num contexto pósmoderno, Isolda desvela a vivência da satisfação sexual antes do casamento.

Na visão de Giddens (1993), as relações afetivas e sexuais anteriores à união do casal tendem a serem postas à parte com maior liberdade do que ocorria antigamente, e a confiança no "relacionamento puro" não tem apoios externos, sendo desenvolvida com base na intimidade do par conjugal, isto é, na vivência da satisfação sexual e emocional no casamento.

Prosseguindo em sua descrição, a colaboradora revela sobre a sua vivência afetiva e sexual no casamento, antes do parceiro lhe ser infiel:

\footnotetext{
dentro do nosso relacionamento, dentro da nossa relação em si, entendeu?, na parte mais sexual, envolvendo a parte sexual, eu sabia que tudo que, por exemplo, ou eu falava ou eu pedia, ou... mesmo que ele queria mas, enfim, tudo o que eu pedia e quisesse, eu sei que ele prontamente fazia ou ele tentaria realizar. Sabe uma pessoa que sempre quis me agradar nesse lado? [da sexualidade].
}

Compreendemos no relato de Isolda, que Tristão sempre procurou satisfazê-la sexualmente, apesar de Isolda considerar-se mais experiente do que ele no que diz respeito às vivencias sexuais. Além disso, a colaboradora desvela a iniciativa feminina nas vivências sexuais, expressando a existência da ars erótica no relacionamento para que haja a sua continuidade (Giddens, 1993).

Logo no início do casamento, Tristão precisou “trabalhar fora” e o casal foi morar em cidades diferentes. Esse momento coincidiu com a primeira gestação do casal, e nesse período Tristão foi infiel a Isolda pela primeira vez.

A colaboradora relata que a gravidez inibiu a expressão de sua sexualidade durante o período pré-natal, bem como no período pós-natal: “nos nove meses a gente acabou 
tendo, claro, a gente tinha relações nesse período também [durante a gravidez], mas, logo no finalzinho não, depois eu fiquei muito tempo afastada tal, aquela coisa...”.

Assim, houve não somente a distância física do casal, mas também uma distância afetivo-sexual.

A colaboradora relata ainda que, até a gravidez, momento tão significativo em sua existência, ela nunca havia notado nenhuma “mudança” de Tristão no casamento, isto é, em relação à vivência da sexualidade na parceria, porém, relata as dificuldades enfrentadas nesse período:

comigo... também aconteceu uma sensibilidade extrema porque eu tinha tido nenê [ênfase], né?, por ter ficado um longo tempo, 'né? separados, eu tendo a criança aqui i ele trabalhando, batalhando por lá e vinha muito de vez em quando. Mas o período pós [ênfase], 'né? nascimento, não tivemos relações nenhuma [ênfase], 'né? por todo esse problema de ter o nenê...

No relato acima podemos compreender que a colaboradora atribui um significado importante à vivência da gestação ao considerá-la um "problema”, um desencadeador de dificuldades.

De acordo com o estudo realizado por Bruns \& Pereira (2001), é comum que durante o período de gestação, as relações sexuais entre o casal se tornem menos freqüente; o que se deve também às alterações hormonais da mulher. Isto porque o interesse, o desejo e a sensualidade assumem nuances que vão além das transformações fisiológicas, mas que se carregam por mitos e preconceitos construídos pelo ethos cultural a exemplificar: “... à mulher grávida não caberiam relações sexuais e nem sequer desejos, pois o dever da função procriadora já estava consumado” (BRUNS \& PEREIRA, 2001).

Ao tornar-se um sacramento, o casamento tornou-se o lugar legítimo para a vivência da sexualidade, sendo respeitadas as prescrições da Igreja Católica e tendo como dever a 
procriação. Porém, em um universo em que uma maior liberação sexual entre homens e mulheres foi alcançada, o arquétipo da mulher santificada pela gravidez ainda existe.

Na visão de Pincus e Dare (1978, p.49): “... o nascimento, como a morte, é cheio de mistério, e nenhuma preparação prática chegará ao âmago dos medos e fantasias secretas acerca do nascimento, de como será o bebê e o que ele significará para todos”.

A chegada de um bebê na família, desse modo, é um drama familiar no qual a relação do casal pode encontrar ressonantes afetações provenientes da relação entre os dois protagonistas principais: mãe e recém-nascido. “... enquanto que a nova mãe pode recapturar o sentido de uma proximidade a dois em relação ao seu bebê, o novo pai terá de lutar com o sentimento de perda até que a família possa, encontrando um lugar para ele, criar um novo relacionamento a três” (PINCUS \& DARE, 1978, p. 50).

A partir dessa perspectiva, podemos perceber que Isolda encontra dificuldades entre vivenciar o seu papel de esposa e de mãe, de mulher santificada e sexualidade.

\footnotetext{
sabe como é a cabeça de um homem, muda também quando a mulher 'tá grávida, por mais que tenham relações [relações sexuais] que ache que é normal [a gravidez], nunca é normal, é diferente, é um pouco complicado, pelo menos no nosso caso ...
}

Isolda relata que o homem também passa por um momento de desestruturação na gravidez do casal e, apesar de enfrentar dificuldades quanto à vivência do erotismo na gestação, ela não sabe ao certo falar sobre as suas angústias e aflições que invadem esse momento existencial.

Em relação aos homens, Pincus e Dare (1978) afirmam que alguns pais, mesmos aqueles relativamente maduros e cooperativos na relação a dois, podem se comportar de maneira infantil, desejando que eles mesmos sejam tratados como bebês, durante a gravidez do casal. Alguns podem sentir ciúmes da esposa, bem como do bebê e, outros, passam a vivenciar o isolamento e o descomprometimento nessas relações ao partilharem 
da idéia de que “ter um bebê é coisa de mulher”, que se ancora na ambivalência da mãe em compartilhar o bebê com o pai.

Diante dessa situação, Isolda expressa em seu relato que Tristão lhe foi infiel pela primeira vez durante a primeira gestação do casal e nos conta como foi essa traição. Relata inicialmente que percebia o marido ausente na relação, física e emocionalmente, e que provocou a confissão de sua infidelidade:

... eu comecei a provocá-lo por mais que me doesse [ênfase], porque eu sabia que de outra maneira espontaneamente jamais iria falar, 'tá? [...] eu comecei a falar que isso [a possibilidade dele lhe ter sido infiel] me estimulava, que se tinha acontecido alguma coisa [infidelidade] que eu que, eu lógico, que eu entenderia porque eu tive, né? nos nove meses a gente acabou tendo, claro, a gente tinha relações nesse período também, mas logo no finalzinho não, depois eu fiquei muito tempo afastada tal, aquela coisa ... i ele ... meio que ficou meio que chocado [ficou chocado com a dúvida da esposa sobre a sua fidelidade] : "não imagina não tive nada, não aconteceu nada, eu fiquei por aqui, eu saia com os meus amigos e voltava pra casa mas, nunca teve nada”.

Isolda parece culpar-se pela infidelidade de Tristão por ter ficado grávida e ter vivenciado dificuldades quanto ao exercício da sexualidade nesse período, e se culpa também por ter “provocado” a sua confissão.

Após Tristão ter negado que lhe era infiel, Isolda ainda insistiu em sua confissão:

... "não me fala, você sabe que isso me põe o maior fogo. Isso, vai ..., vai, me deixar mais acesa, conta, eu preciso ouví”, jogando isso .... Isso [ênfase] [provocar a confissão do marido] não estava me fazendo bem, mas, eu queria saber de alguma maneira porque eu tinha percebido aquela rea/atitude dele diferente. Até que ele falou: "bom [ênfase], te vai te excitá mesmo? Você... vai ficar bem se eu te contar?" Eu falei: "Vai, vai, que eu 'tô ficando ótima, pode contando.” Ele começou a falar ... [que lhe tinha sido infiel].

Tristão assume sua infidelidade. E prosseguindo em sua descrição, Isolda nos relata como foi essa traição:

[Tristão] saiu com os amigos para uma outra cidade [diferente daquela que ele residia] onde tinha uma boate, onde tinham várias garotas de programa ... e até 
então, desde o nosso casamento, isso já faziam ... três anos, três anos de casada, ele nunca procurou [uma outra mulher para se relacionar], nunca, né? foi atrás de nada [de uma outra mulher]. Mas quando eu 'tava fora [ênfase] [morando em outra cidade], que já 'tava fazendo três anos de casados, ele foi com esses amigos numa, numa danceteria, numa boate, não sei... de garotas de programa, 'tá ? Tinha show de stripe [ênfase], era um monte de coisas e tal... e ele foi [ênfase] e ele começou a beber, todos os amigos beberam, eles estavam em vários [ênfase], 'tá?, em vários amigos ãh... uns casados, outros não [ênfase], ah, mas que se aproximou uma garota .... [pausa de 10 segundos], [risos]... que se aproximou uma garota ... que sentou na mesa que provocou tudo e ele acabou... entrando nessa, ele foi, tal, pela primeira vez ele tinha me traído com essa garota.

Segundo a perspectiva de Isolda, a garota de programa é a culpada pela infidelidade amorosa de Tristão quando a colaboradora diz que ela "provocou tudo”. Por outro lado, o ambiente em que Tristão se encontrou com ela pode sugerir que ele esteve lá justamente em busca de sua satisfação voluptuosa.

Retomando Pincus \& Dare (1987), a própria data do nascimento do bebe é um momento em que, enquanto alguns homens sentem-se satisfeitos e excitados com o nascimento dos filhos, outros se ausentam neste dia, embriagam-se e encontram-se com prostitutas, até ao mesmo tempo em que suas mulheres estão em trabalho de parto. Alguns homens vivenciam suas inseguranças e aflições afastando-se da esposa, alienando-se no trabalho ou mesmo buscando satisfações nas vivências eróticas com as prostitutas, tal como é descrito por Isolda acerca da vivência de Tristão.

As relações entre os gêneros são construídas de modos diferentes para os homens e para as mulheres, porém, as crenças e valores éticos e culturais, tão enraizados no psiquismo de cada um de nós, são transmitidos para ambos os gêneros em igual proporção. Isso quer dizer que se para as mulheres o arquétipo social demarca sua dificuldade em viver o erotismo na gestação, os homens também tem conhecimento disto, mesmo que inconscientemente. 
Em nosso existir cotidiano vivenciamos muitas vezes ações não planejadas e irrefletidas ou pré-reflexivas, que tomam conta do nosso ser. Na descrição de Isolda, a colaboradora afirma que Tristão "se arrependeu" de ter tido relações sexuais com a prostituta quando a esposa estava grávida. A não reflexibilidade de nossas ações cotidianas é expressa pela vivência de Tristão quando “ele mantém relações sexuais com a prostituta, mas depois se arrepende”.

O arquétipo coletivo do homem “machão” que afirma a sua virilidade pelo exercício do sexo é transmitido psiquicamente geração após outra (Eiguer,1998).

Desse modo, pela perspectiva psicanalítica, afirmamos que a existência de um inconsciente coletivo abarca tantas outras possibilidades de ser, que, embora irrefletidas pelo homem, são cometidas.

Bruns e Pereira (2001) também corroboram com a idéia de incorporação e transmissão de valores, mitos e ideais de uma determinada cultura e sociedade, afirmando que muitas das angústias que demarcam a gestação se devem à vivência do conflito entre “o modo de ser mãe” e o “modo de ser mulher”, fruto de restrições culturalmente incorporadas pelas mulheres e, também pelos homens, no decorrer de nossa história sóciocultural. Na impossibilidade de associar maternidade e feminilidade à sexualidade, a imagem internalizada de mulher casta, vem à tona.

... ao permitir-se a entrega aos desejos e prazeres sexuais ela será vista pela moral como uma mulher devassa - tal como a prostituta e, contrapondo-se a essa atitude, será o modelo valorizado de feminilidade, de esposa ordeira, casta, mãe de família e, sobretudo, dessexualizada (BRUNS \& PEREIRA, 2001).

Ao trafegar entre homem e mulher, a educação sexual transmite a ambos a filosofia de que o homem também deverá proteger a esposa grávida dos pecados do sexo, no período de gravidez. 
Prosseguindo em sua descrição, Isolda desvela que em sua vivência temporal, quando engravidara pela segunda vez, após seu primeiro filho completar cinco meses de idade, a possibilidade de que as traições persistissem fora para sua realidade psíquica ameaçadora da instabilidade de sua identidade egóica e vivenciara um conflito entre ser ou não novamente mãe:

\footnotetext{
logicamente assim... eu grávida novamente, meu emocional, sabe?, super alterado, uma alteração de humor extrema, eu 'tava bem, ora eu 'tava mal, ãh... a não aceitação, a não aceitação ... Não, gostaria claro de ter [de ter outro filho], queria ter meu segundo filho, mas não esperava ser tão rápido. Tudo aquilo me deixou, sabe? super ãh..., acabou afetando a gente. Sem ter alguma desculpa, ele também saiu 'prá essas duas vezes [traições], com mais duas pessoas e ainda repetiu com uma delas, ‘né?
}

Seu relato mostra a não aceitação da gravidez, que camufla o sentido prenunciativo de uma segunda traição e de sua não aceitação: “Então, tudo isso [a possibilidade do marido lhe ser infiel novamente, bem como o sentimento de culpa], vol-tou-na-mi-nha cabeça. Durante todo esse período [desde a primeira gestação] até o nascimento do segundo filho eu sempre ficava provocando isso [a confissão do marido sobre suas infidelidades]”. E de fato, Tristão confessou-lhe que lhe fora infiel outras vezes e não somente com prostitutas.

Os momentos angustiosos e aflitivos da primeira gestação se aliavam, na atemporalidade do inconsciente, a nova gestação. Sem poder ter controle de seu destino, a colaboradora se percebe “vivendo uma situação idêntica”.

Quando nos damos conta de que somos um ser existente no mundo, podemos colocar nos tanto diante de uma situação concreta, quanto no vislumbramento de infinitas possibilidades de ser.

O ser humano pode assim, transcender a situação imediata, ultrapassar o momento concretamente presente, o espaço e o tempo objetivos, avançar ou retroceder em sua historia, tal como percebemos na descrição da colaboradora. Ordenado pelo temporalizar 
do inconsciente a existência de acontecimentos vividos nos acontecimentos atuais se faz presente.

Assim, a segunda gestação do casal re-ativou os mesmos sentimentos vivenciados por Isolda na primeira gravidez: as angústias frente à gestação e à sexualidade e as angústias frente à infidelidade do marido, a ponto do casal empreender como uma tentativa de solucionar o drama, a submissão de Isolda a uma intervenção cirúrgica, a laqueadura, após o nascimento do filho.

... eu precisava, entendeu? então, parar com isso [gravidez $\leftrightarrow$ infidelidade], por isso que a gente também resolveu em acordo, após o segundo nascimento, eu ia fazer uma laqueadura 'prá gente poder ficar com um pouco mais calma e também não tinha condições da gente ter mais filhos. Então, isso [a infidelidade $\leftrightarrow$ gravidez] a gente tinha resolvido...

Com a laqueadura, parece-nos que Isolda buscava impossibilitar a entrada de mais um ente na família, a terceira figura, seja esta o filho ou a prostituta.

Aflita e insegura em relação a manter o marido ao seu lado, torna-se explícito, manifestado, o desejo que tinha de não ter mais nenhum filho após o nascimento do segundo, o que se traduz no desejo implícito, camuflado, latente de "preservar a relação dos perigos e infortúnios da infidelidade”.

Sigmund Freud enunciou em 1898, no texto “A Interpretação dos sonhos”, uma distinção entre “conteúdo manifesto” e “conteúdo latente”. Embora tenha formulado suas definições a partir da análise dos sonhos, é evidente que os dois conteúdos desvelam-se em toda e qualquer manifestação humana.

Na perspectiva psicanalítica o “conteúdo manifesto” é uma deformação do “conteúdo latente”, que se dissimula por trás do que está manifesto.

Nos dizeres de Roudinesco e Plon (2004, p.394), no caso dos sonhos:

Essa deformação é a marca de uma defesa contra o desejo veiculado pelo sonho. Freud compara a deformação do sonho à polidez, que muitas vezes consiste em disfarçar pensamentos agressivos ou negativos através 
de fórmulas amáveis. Portanto, efetua-se no sonho uma censura inconsciente a uma moção de desejo: quanto mais severa é a censura, escreve Freud, mais completo é o disfarce.

Nessa perspectiva, compreendemos que as manifestações latentes nos relatos de Isolda são muito revestidas de censura, de segredo e de disfarce e por isso expressam muito bem, a teoria freudiana.

Prosseguindo em sua descrição, Isolda diz ter se afastado do marido: “foi uma época que realmente eu não estava presente na vida, que eu nunca tive tempo para ele, depois que as crianças nasceram eram só as crianças em primeiro lugar ah... sempre cansada...”.

Percebemos que, silenciosamente, a culpa pela infidelidade por parte de Isolda e não somente por parte de Tristão, que a expressou pelo seu arrependimento, também se manifesta quando ela diz ter estado ausente e quando diz ter optado por realizar uma laqueadura.

Nesse momento, Isolda se faz cúmplice da infidelidade alheia.

Para Bruns e Pereira (2001), o conflito entre o desejo sexual e a culpa não são vivenciados somente pelas mulheres durante a gestação, mas pelos homens também.

De um lado, deparam-se com o desejo, os impulsos de Eros que os levam a sentir-se atraídos por outras mulheres; do outro lado, o sentimento de culpa por estar sendo infiel à parceira e ao filho. Este sentir e racionalizar; desejar e reprimir ou sublimar esbarra em valores e culpas internalizados (BRUNS \& PEREIRA, 2001, p.99).

A culpa é, na perspectiva psicanalítica, a expressão da agressão do eu contra si mesmo com base em um julgamento moral estabelecido pelo supereu, que entre as três instâncias psíquicas formadoras da personalidade, é fundada pela construção sócio-cultural na qual o indivíduo está inserido.

O supereu é o responsável pela interiorização da autoridade, ou seja, das exigências e das proibições dos pais na consciência da criança, e no papel de juiz contribui para a 
formação da consciência moral do indivíduo e de seu equilíbrio psíquico quanto a sua integração à sociedade.

Sendo assim, o "sentimento de culpa” vivido por Isolda está relacionado às imposições do supereu, as quais se pautam nos papéis sociais e sexuais distintos entre homens e mulheres, pré-estabelecidos socialmente.

Tais imposições remetem à idéia de que a mulher deva ser a principal responsável pela felicidade do marido no casamento, de modo que, o não cumprimento do dever feminino acaba por acarretar a culpa. (Áries, 1981; Lins, 1997 e; Chauí, 1991; entre outros).

Prosseguindo em sua descrição, a colaboradora revela uma outra dimensão existencial do fenômeno no casamento: o amor e a dor vividos a partir da infidelidade de Tristão e o luto empreendido nesse processo.

Isolda relata que se sentiu “magoada” com a infidelidade amorosa do parceiro:

Então essa magoa é assim... é do porquê ele sempre falou que "nossa [ênfase], que eu sempre fui a mulher da vida dele, que ele sempre se realizou muito comigo”, apesar de eu ter, sabe?, os meus os meus probleminhas, de eu ser, sabe?, Ele acha que eu 'tô sempre muito fria com ele, que eu não sou uma pessoa carinhosa e tal, mas que sempre fui a mulher ideal 'prá ele, o tipo de mulher que ele sempre gostou e tal. Então, por quê que ele foi procurar outra? O que mais me doeu foi quando ele contou daquela que ele saiu mais de uma vez [ênfase], que ele saiu mais de uma vez. [...] mas que ele contou que foram só essas duas vezes que ele saiu com ela, tal.

A partir da descrição da colaboradora, compreendemos que a idéia de relação amorosa idealizada e fundamentada na crença do amor romântico vem alimentando as nossas idéias sobre a felicidade do amor na atualidade.

Isolda versa sobre o desencantar da relação amorosa quando descobre que o marido lhe é infiel e a mágoa e a decepção sentidas referem-se às crenças implícitas no ideal do amor romântico: crenças estas pautadas nos ideais de eternidade, exclusividade e perfeição 
do amor que parecem ser rompidas quando Tristão se torna infiel, ou seja, quando afirma ter tido outras parceiras sexuais e quando as queixas sexuais que o marido lhe tem, tais como Isolda se refere: "os seus probleminhas”, tornam-se conscientes para a colaboradora.

Embora tenha se desiludido com o amor de Tristão, a colaboradora nos relata que a traição com a prostituta podia ser tolerada: “... bom [ênfase], aí, claro que na hora pra mim ‘foi garota de programa mesmo?, não é ninguém que eu conheço?’”. Ao tomar a figura da prostituta, Isolda despersonifica o ser feminino presente na imagem desta e revela ainda satisfação e aceitabilidade da traição, já que manter relações sexuais com prostitutas por meio de um self-service sexual implica, em nossa cultura, numa descontinuidade de relação do ser humano com o seu objeto de prazer.

o sentido do erotismo dá-se de maneira diferente para os homens e para as mulheres. O erotismo feminino caracteriza-se pela necessidade da presença amorosa contínua de seu parceiro, da continuidade do desejo, da atenção, da paixão, do cuidado. Já no erotismo masculino há uma preferência profunda pela descontinuidade do prazer sexual. As fantasias eróticas masculinas possuem algo antagônico ao compromisso, à responsabilidade, ou seja, há um anseio inquieto de liberdade (ALBERONI, 1988, apud BRUNS \& PEREIRA, 2001, p.85).

A citação acima vai ao encontro da vivência relatada por Isolda que, enquanto mulher, busca a manutenção da durabilidade do casamento e deseja a sua exclusividade afetiva e sexual. Em seu discurso, a colaboradora enfatiza ainda quantitativamente a baixa freqüência de relações sexuais extraconjugais vivenciadas pelo marido: “foram quatro vezes, além de que, na primeira delas, Tristão se relacionou com uma prostituta”, e supervaloriza a descontinuidade das relações sexuais tidas fora do casamento, relações destituídas de laços afetivos.

A permissibilidade dirigida aos homens para manter relações sexuais com as prostitutas é fruto da construção histórica sócio-cultural de nossa família cristã e como 
elucida a descrição de nossa colaboradora, é uma prática confirmada nos dias atuais, expressando uma das formas do ser masculino vivenciar a sua sexualidade.

Entretanto, é interessante afirmar que essa prática não se restringe atualmente aos gostos e prazeres masculinos, mas encontra ressonância nas satisfações sexuais dos corpos femininos, muitas vezes de distintas senhoras que se encontram, silenciosamente, com os “garotões” e pagam a eles pelos serviços sexuais prestados.

Desse modo, enquanto algumas práticas sexuais transitam de modo igual entre os espaços masculinos e femininos, outras são ainda expressões de crenças que diferenciam as psiques dos seres masculinos e femininos. No caso de Isolda, mesmo tendo vivenciado certa liberdade sexual antes do casamento, ou seja, tendo tido vários parceiros, ela ainda aponta para as possíveis diferenças existentes entre os sexos:

Ele é um tipo de pessoa que, se eu deixasse ele quer [quer fazer sexo] todo dia, uma pessoa super ativa, 'tá? Não por ser mais novo, mas é homem, homem tem um fogo [ênfase] diferente, então ... ficou ... ficou durante um bom /eu comecei a lidar depois de muitos anos, claro, com o tempo tudo começou a amenizar.

Seu discurso revela que "naturalmente”, “o homem tem maior desejo sexual que a mulher”, crença que se articula em seu discurso latente com “a permissibilidade e aceitabilidade da traição masculina”. Nessa perspectiva, ao homem cabe ser mais experiente nas vivências sexuais do que a mulher. Após o casamento, cabe a ele ainda encontrar-se com prostitutas, cuja atividade sexual é desvalorizada socialmente. Esta figura é tal como percebemos no discurso de Isolda, estigmatizada, porém descategorizada até os dias atuais. Contudo, ao retornarmos ao discurso acima, "o que mais me doeu foi quando ele contou daquela que ele saiu mais de uma vez [ênfase]”, referindo-se à vivência sexual de Tristão com uma moça “não prostituta” e por isso mesmo sugerindo uma ameaça à perda do amor, percebemos que a colaboradora se sente ameaçada ao saber que o marido teve relações com uma mulher não prostituta, o que não ocorre no primeiro caso. Mas que 
ameaça é essa? A partir da perspectiva psicanalítica, diríamos que é a ameaça de uma possível perda do ser amado, ou do seu amor.

A diminuição da afetividade e do exercício da sexualidade ocorridos no casamento, seja em virtude das ansiedades e expectativas advindas da gestação, seja em virtude da distância geográfica que separou Isolda e Tristão, faz com que a colaboradora demonstre em seus relatos uma angústia por temer perder o amado. Essa angústia parece compor o drama do "sentimento de culpa".

Retomando nossos apontamos sobre esse sentimento, afirmamos que na perspectiva de Nasio (1997), a “culpa” é uma variante da angústia, que é, por sua vez, uma reação à ameaça de uma eventual perda do ser amado ou do seu amor. Desse modo, ela é também uma reação à ameaça do amor do amado à guiza de um castigo por uma falta, real ou imaginária, cometida ou que poderia vir a ser cometida pelo sujeito, castigos esses merecidos, que se revelam na vivência de Isolda, mesmo que camufladamente pela ordem do inconsciente, na expressão de um sentimento de não ter sido uma boa esposa.

Ao retomarmos a ótica de Forghieri (2001), podemos dizer que os momentos de profunda angústia vivenciados pela colaboradora quando o parceiro lhe trai, refletem uma “maneira preocupada” do ser humano existir.

Na perspectiva forghieriana, as preocupações que vivemos podem variar desde uma vaga sensação de intranqüilidade até uma profunda sensação de angústia que pode até mesmo, nos dominar por completo.

Assim, uma “maneira preocupada de ser” pode nos abarcar tanto em situações concretamente presentes, como em situações em que apenas nos lembramos, ou seja, trazemos à consciência, e até mesmo referir-se àquelas situações nas quais temos receio de que aconteçam, sem ao menos percebermos, as razões do aparecimento desse receio. 
Tal como compreendemos na descrição da colaboradora, uma "maneira preocupada de ser” retrata as manifestações de angústia sentidas por ela durante a segunda gravidez do casal. Isto porque o inconsciente trabalha em sua lógica, alterando a ordem dos acontecimentos cronológicos e re-atualizando sentimentos outrora vividos. Compreendemos também que na descrição de Isolda, a dinâmica da “culpa” se relaciona à “dor psíquica” vivida por ela. Na tentativa de compreender esta última, indagamos: "que dor é essa, a da traição, que é sentida por Isolda?”.

Entretanto, percebemos que mesmo sentindo dor quando o parceiro lhe trai, a colaboradora diz também ter sentido prazer, como vemos no relato abaixo:

\footnotetext{
Realmente no ato em si, quando ele me contou [descreveu a relação sexual com a prostituta], me excitou realmente, no ato em si quando ele me contou. Não consigo interpretar esse tipo de sentimento, mas me excitou, entendeu? Fiquei como se fosse assim, sabe?, então, "agora eu vou fazer mais do que a menina fez para ele se arrepender de ter procurado uma outra fora de casa.” Não sei se foi isso, mas que eu tive esse tipo de sentimento, sim ..., me excitou prá caramba, ah:::, gostei do que eu fiz na hora, assim, do prazer que eu senti, e claro que não da "coisa” [infidelidade] , do que eu escutei [a confissão], por ser ele [o marido].
}

Dotada da capacidade humana de transcender à situação imediata, Isolda ocupa o lugar da prostituta, o lugar de sua fantasia, numa transcendência do real ao dizer que: “agora vou fazer mais do que a menina fez para ele se arrepender de ter procurado outra fora de casa”, desejando satisfazer sexualmente o marido mais do que aquela mulher possa ter feito.

Para Nasio (1993), o mecanismo formador de qualquer fantasia é produzido através da alucinação. Na fantasia, o sujeito torna-se objeto. A fantasia comporta uma cena com personagens, uma ação, um afeto predominante [emoção e/ou tensão] e a presença, na cena, de uma parte definida do corpo. Exprime-se não somente pelo relato, mas pelas ações, sonhos e devaneios do sujeito, que se repetem e, em geral, permanecem inesquecíveis. O 
sujeito vive a fantasia como um elemento enxertado, que se impõe e se repete independentemente de sua vontade. A fantasia contém a perversão, de modo que o aparecimento da fantasia e a prática de fato, são vergonhosos.

Segundo a perspectiva de Nasio (1997), existem três definições para a dor psíquica ou dor do amor:

(1) como sendo afeto que resulta da ruptura brutal do laço que nos liga ao ser ou à coisa amada;

(2) como sendo sintonia numa manifestação exterior e sensível de uma pulsão inconsciente e recalcada, incluindo neste conjunto todas as dores psicogênicas;

(3) como sendo objeto e alvo do prazer sexual perverso sadomasoquista. Esta última definição parece, pois, explicar o prazer sentido por Isolda na revelação da infidelidade pelo próprio marido. A dor aparece, neste caso, como objeto da fantasia sadomasoquista, isto é, como uma satisfação sexual.

A dor, na pulsão sadomasoquista, só aparece ao fim de três tempos da pulsão:

(1) O da agressividade ou do sadismo originário, na forma ativa, o tempo de “atormentar”. Nesse primeiro impulso da pulsão sadomasoquista, o alvo é atormentar o outro, mas sem a intenção de fazer-lhe mal ou de gozar com o seu mal. Trata-se de uma vontade de vencer o outro e dominá-lo, sem fazê-lo sofrer.

(2) O do masoquismo, na forma passiva, o tempo de "ser atormentado". Trata-se do tempo do retorno contra si dessa primeira tendência sadoagressiva. Neste retorno o eu experimenta verdadeiramente a dor e goza masoquisticamente ao sofrê-la. São a dor e o prazer provocados pelo 
tormento que um outro suposto sádico, o próprio eu, ou melhor, uma parte do eu, lhe infligiria. O eu se cinde em dois: o que faz o mal e o outro que sofre e goza ao experimentar esse mal.

(3) O do sadismo secundário, na forma reflexiva, o tempo de "atormentar a si mesmo”. Se sentir dor se torna um alvo masoquista, pode aparecer retroativamente o alvo sádico secundário de provocar a dor no outro. Neste tempo a tendência é fazer o outro sofrer e assim, ter prazer com a sua dor. “[...] a pulsão volta duas vezes sobre o eu: uma primeira vez quando tem um prazer masoquista em ser atormentado pelo outro (segundo tempo), e uma segunda vez quando se trata de sentir a mesma dor que o outro atormentado sente. O eu atormenta a si mesmo, faz mal a si mesmo para saber o que sentirá o outro atormentado” (NASIO, 1997, p.125).

Quer se trate da dor do primeiro tempo, a que se inflige sem intenção maldosa; quer se trate da dor do segundo tempo; a que se sofre masoquisticamente; ou daquela do terceiro tempo, a da identificação com o outro sadizado, a dor é sempre masoquista, isto é, é o prazer de uma dor sofrida pelo eu.

“No âmbito da pulsão sadomasoquista, a dor é sempre sofrida pelo $e u$, seja porque ele próprio a sofre, seja porque ele se identifica com quem sofre. [...] nem se deveria falar de pulsão sadomasoquista, mas de pulsão masoquista apenas” (NASIO, 1997, p. 126).

Podemos interpretar o prazer de Isolda na confissão do marido, que, ao final, transforma-se novamente em dor, devido ao sadizamento do próprio eu.

Na seqüência de seu relato, a colaboradora diz:

[A infidelidade] Abalou muito [ênfase] o relacionamento da gente porque eu... eu fiquei super insegura e perturbava ele toda noite com isso e ele falava que isso já não ‘tava deixando ele mais legal...”, e desvela pulsão sadomasoquista: “...nessa, 
eu, eu fiz uma armadilha, eu mesmo caí. Ele também, 'né? Demorou pra gente se re-erguer, ele também ficou muito mal, sentindo ser péssimo marido, ele também se culpou, ele também se puniu, no sentido que ele jamais ia fazer isso comigo.

Ao constatar o "sentimento de culpa" vivenciado pelo marido, percebemos que Isolda sente prazer no sofrimento dele.

Nasio (1997), ainda propõe duas espécies de dores psíquicas, ou seja, duas formas de reagirmos à dor do amor: (1) quando estamos preparados para ver o amado partir: vivemos a sua morte como uma dor infinita, mas representável, como se o trabalho de luto já tivesse começado antes do seu desaparecimento. Nesse caso, a dor, embora insuportável, fica integrada ao eu e se compõe com ele; (2) quando a perda do outro amado é súbita e imprevisível: a dor se impõe sem reservas e transforma todas as referências de espaço, tempo e identidade. Nesse momento, a dor, inassimilável pelo eu, é marcada com o selo da subtaneidade e do imprevisível.

Ao relatar sobre o modo que se sentiu ao saber que o marido lhe era infiel, Isolda afirma que "o maior problema foi com a auto-estima" e nos revela o adoecimento do eu:

Eu fiquei muito lá em baixo, sabe?, me sentindo assim... por eu já ser uma mulher mais velha do que ele, seis anos mais velha, apesar de não, num parecer fisicamente 'tá ...?, [...] tudo, então isso [a infidelidade dele] começou a me deixa [ênfase] claro, sabe?, bem pra baixo né ?, me sentindo velha, que eu não tinha motivação prá isso [para a atividade sexual], que eu não ia conseguir manter uma pessoa mais jovem do meu lado, ainda mais pondo filho em seqüência, que eu precisava, entendeu?, [...]. Eu ficava super insegura, entrei numa paranóia. [...] no ato que ele ia tomar banho eu corria para carteira dele, fuçava pra ver se eu via bilhetinhos. Eu ia no celular pra ver se achava celular diferente, se eu achava um celular estranho que não era, que não tinha nome identificado de algum homem, eu já ligava [...] Foi uma neurose, entendeu? Uma “neura” mesmo, numa paranóia ...

A insegurança, a baixa auto-estima, o medo, a falta de motivação e de significados existenciais, isto é, um amplo sentimento de preocupação e intranqüilidade caracterizou o seu modo de ser em um determinado momento existencial. 
Segundo Nasio (1997), os objetos amados ou eleitos são ao mesmo tempo tão internos, tão íntimos, tão intrinsecamente ordenados pelo movimento do desejo, que vivemos sem perceber a solidez do seu enraizamento no inconsciente, de modo que, somente quando somos ameaçados de perdê-lo ou depois de perdê-lo, a sua ausência revela dolorosamente a profundidade desse enraizamento.

Nessa visão, não é a ausência do outro que dói, mas são os efeitos em nós dessa ausência. Não sofremos com a falta do outro, mas sofremos porque a força do nosso desejo fica privada do excitante que a sensibilidade do corpo vivo do outro significava para nós. Sofremos porque o ritmo simbólico dessa força fica quebrado com o desaparecimento do compasso que as suas excitações escondiam. E sofremos também porque o espelho psíquico que refletia as nossas imagens desmorona por falta do apoio vivo em que o corpo do outro havia se transformado.

A lesão que provoca a dor psíquica não é, pois, o desaparecimento físico do ser amado, mas o transtorno interno gerado pela desarticulação da fantasia do amado. Desse modo, a dor psíquica ou dor de amar não é dor de perder, mas dor do caos das pulsões enlouquecidas. Em suma, o sentimento doloroso reflete não as oscilações regulares das pulsões, mas uma loucura da cadência pulsional. Para Nasio (1997, p.52), a dor psíquica é:

a desorientação que sentimos quando, tendo perdido um ente querido [mesmo que essa perda seja simbólica] nós nos encontramos diante da mais extrema tensão interna, confrontados com um desejo louco no interior de nós mesmos, com uma espécie de loucura do interior que fica adormecida em nós, até que uma perda exterior venha arrancar os seus gritos de desespero.

Com base na construção teórica de Nasio (1997), compreendemos que a vivência de dor psíquica é expressa na comoção pulsional ou auto-percepção do eu sobre o tumulto interno desencadeado pela perda ou ruptura da imagem do outro amado, o que significa nessa investigação, a ruptura que o parceiro(a) traído(a) tem de quem lhe foi infiel e, ao mesmo tempo, pela ruptura de sua própria imagem. 
Diante da dor das pulsões enlouquecidas, o eu necessita do "trabalho de luto" para se reerguer. É por meio do “trabalho de luto” que nossas novas significações são atribuídas ao outro e a nós mesmos, isto é, a nossa existência enquanto um ser-no-mundo.

O processo de "luto" necessita ser completado para que a relação amorosa possa reconstruir-se, para que se estabeleçam novos limites, novos horizontes e se possibilite ao homem e à mulher, vivenciarem momentos de sintonia e tranqüilidade consigo mesmo e com o(a) parceiro(a).

Prosseguindo em sua descrição, Isolda diz que “superou” essa fase, “mas doeu demais... a ponto de eu achar assim: teve uma fase calmaria, teve uma fase que eu fiquei muito bem com ele, parei com as 'neuras'”.

\footnotetext{
Ah, assim, ficamos bem, que quase que... é como se eu tivesse... bloqueei mesmo. Bloqueei aquilo que aconteceu. Eu me via como a pessoa mais importante na vida dele, como se não tivesse acontecido, é como se não tivesse acontecido [ênfase]. Eu colocava bem assim "me contou, foi real, aconteceu, doeu, 'tá?, mas eu não vi, não participei”. Então, tem aquele ditado... "O que os olhos não vêm, o coração não sente.”... Sente [ênfase], mas não sente com a intensidade. Claro, se tivesse pêgo num, no flagra, ou uma coisa assim... [...] eu bloqueei essa mágoa por um bom tempo porque eu sabia, se eu tivesse, eu tinha que perdoar de alguma maneira pra eu conseguir viver bem, pra eu conseguir resgatar um pouco o casamento da gente que 'tava assim ainda muito no começo, com crianças pequenas.
}

Em nossa vivência cotidiana, temos que lidar com a ansiedade advinda dos momentos de tensão e de desprazer em que somos naufragados, momentos esperados e, muitas vezes, imprevistos e que emergem com situações reais e imaginárias, quando o nosso psiquismo ou alguma parte do nosso corpo sofre uma ameaça tão intensa que não conseguimos ignorá-la, dominá-la ou descarregá-la, assim como percebemos na vivência relatada por Isolda (Fadiman, 1979).

Para Forghieri (2001), sendo as inquietudes existenciais manifestações inerentes de nossa condição de ser-no-mundo, “o modo preocupado de existir” é carregado de angústias 
e ansiedade e emerge quando sofremos grandes contrariedades, enfrentamos momentos de perigo ou precisamos assumir decisões importantes. A perda de um objeto que desejamos, isto é, a perda de seu amor, a perda de nossa própria identidade, e a perda de nossa autoestima são para Fadiman (1979) alguns dos mais importantes eventos que causam ansiedade, e nessa perspectiva dispomos de dois modos de reagir a ela: lidando diretamente com a situação enfrentando os problemas ou fugindo das ameaças, a fim de minimizar os impactos, ou ao defendermo-nos dela, “negando” a própria situação.

Quando “negamos” a realidade, o eu, na perspectiva psicanalítica, protege todo o nosso psiquismo contra a ameaça, falsificando a natureza desta e distorcendo a realidade por meio de um mecanismo de defesa chamado "negação”.

O eu é a parte do aparelho psíquico responsável por garantir nossa segurança e sanidade mental e é submetido a todo o momento às exigências do id, aos imperativos do supereu e às coerções da realidade.

Em 1894, no texto: “As neuropsicoses de defesa”, Sigmund Freud inaugurou a noção de “defesa” como o eixo do funcionamento neurótico em relação aos processos de organização do eu. Os “mecanismos de defesa” referem-se às proteções do eu contra as agressões internas, provenientes do id, e externas, provenientes do supereu, constituintes de fonte de prazer e desprazer (Roudinesco e Plon, 1998).

Percebemos que na descrição da colaboradora, esta se utiliza de alguns dos “mecanismos de defesa” formulados pela teoria freudiana, sendo dois deles denominados “repressão" e "negação”. Enquanto a repressão consiste em afastar da consciência um evento, idéia ou percepção potencialmente provocadora de ansiedade, impedindo qualquer solução possível, a negação é a tentativa de não aceitar na realidade, um fato perturbador, o que nesse caso é a infidelidade de Tristão. 
Ao prosseguir seu relato, percebemos que Isolda se utiliza ainda de mais uma defesa, a "racionalização”: "Ele me ajuda demais em relação às crianças, a parte sexual a gente sempre se deu bem. Então eu não podia deixar abalar, ‘né?”. “Racionalizar” consiste em achar motivos aceitáveis para pensamentos e ações inaceitáveis, constitui-se num modo de aceitar a pressão do superego, ou seja, as crenças fundadas em um psiquismo familiar, envolto pela ordem social, o que nesse caso se traduz como a valorização de Tristão que, enquanto um bom marido, perpassa o conluio familiar.

Berenstein (1988), afirma que o sentimento familiar é movido por segredos e pactos que podem perpetuar a história da família por gerações. Acontecimentos ocorridos em um núcleo familiar podem ser repetidos das vivências familiares de origem de um, ou dos dois cônjuges e, levar a permanência temporal de uma família adiante.

A colaboradora relata ainda: “ninguém da minha família soube o que houve [que Tristão lhe foi infiel], pois as pessoas da família são de religião católica e tem essa coisa de fidelidade... ninguém nem pode sonhar em saber e... era melhor que ninguém soubesse a respeito do que houve... pois para eles [família] ele é o anjinho da família”.

Em seu relato Isolda diz explicitamente que: “Tristão sempre foi o anjinho da casa”, o que revela, implicitamente, que: “ele é, pois, uma boa pessoa”.

Os últimos relatos encontrados na vivência da colaboradora explicitam o desejo familiar de que as leis da Igreja se perpetuem nos núcleos familiares sucessivos, bem como o comportamento de manter em sigilo atitudes que podem acarretar sentimentos de culpa e de vergonha aos membros da família.

Autores como Eiguer (1998) e Berenstein (1988) consideram que o lugar dos desejos imaginários de cada um dos pais é inspirado na representação de seus antepassados e constitui a trama de negociações intersubjetivas de grupo familiar, sendo transmitidos de geração a geração. 
Nessa transmissão de vida psíquica entre gerações, a soma de dívidas e de méritos é passada de ancestrais a outros, sendo o próprio trabalho psíquico o responsável por impor à psique humana a sua inscrição na geração e na intersubjetividade familiar.

Desse modo, as representações entre as gerações organizam, por exemplo, a escolha de objetos ou de parceiros, veiculam o modelo de parentesco a ser seguido, ordenam atrações, rejeições, prescrições, proscrições e ainda, distribuem o lugar de cada um dos membros na família.

Esse modelo de representações constitui a origem da transmissão de mitos e de ideais e assim, modula os projetos de vida e também intervém na organização do superego individual de cada membro.

Nos dizeres de Eiguer (1998, p. 23-24, grifo do autor): “o tipo de família que se deseja funda, e a educação que se pensa ser a melhor e a mais conforme com o ideal familiar já são pressentidos aí. [...] A complementaridade entre as representações ancestrais em cada cônjuge não é excepcional, e responde a uma lógica particular...”.

Compreendemos a partir da vivência descrita por Isolda, que é por meio dessa transmissão psíquica inerente à estrutura emocional da família que a colaboradora “conhece” o desejo de seus pais em relação ao modo do qual esperam que Tristão se comporte. Que modo é este? Que ele seja “o anjinho da família”, como nos relatou a colaboradora. Ela também reconhece a existência de um desejo parental de que não sejam tornadas explícitas as infidelidades de Tristão.

Desse modo, a colaboradora tende a se comportar segundo uma expectativa familiar, pautada em crenças, mitos, ideais elaborados grupalmente e assim, deve manter em sigilo, em segredo, a traição do marido, a fim de que o que é considerado “sujo” não seja desvelado e o ideal de eu familiar não seja destruído (Eiguer, 1985). 
Pudemos compreender também que seu discurso mantém uma contradição no que se refere ao exercício da sexualidade no casamento pois, se no início de sua descrição, a colaboradora revelara que tem “seus probleminhas” em relação à vivência da sexualidade, relatando o "esfriamento" na relação afetiva e sexual, ela afirma contraditoriamente em um dos relatos citados acima que: “sempre se deram bem em relação à esfera sexual”.

Percebemos assim, que embora tenha direcionado o seu discurso até o momento para as insatisfações e inconcretudes existentes na relação amorosa ao caminhar rumo a reconstrução da relação, ela tende necessariamente a reerguer, supervalorizar a imagem do amado, ou seja, superinvestir no novo ideal.

O mecanismo de racionalização se emprega entre as contradições do inconsciente a fim de preservar intacto o eu, isto é, a sanidade psíquica, pois o outro deve ser valorizado, ou seja, atender às expectativas do "ideal de ego" para que a relação amorosa tenha prosseguimento.

Retomando Nasio (1997), o autor afirma que é diante do transtorno pulsional introduzido pela perda do objeto amado [mesmo sendo uma perda simbólica, uma perda da representação da imagem que temos do outro, tal como o idealizamos] que o eu se ergue.

Encontramos na vivência de Isolda uma perda simbólica do ser amado a partir da qual o objeto conhecido e amado é transformado, re-significado.

Ao iniciar o "luto", o eu apela para todas as forças vivas, mesmo com o risco de se esgotar e as concentra em um único ponto, o da representação psíquica do amado. Por isso é tão difícil para o ser humano desinvestir-se de uma imagem e refazê-la em seu intrínseco eu. Nesses percalços, os mecanismos de defesas tomam espaços, como podemos constatar, por exemplo, o mecanismo de negação, negar o outro traidor. 
Quando a dor psíquica é o afeto que traduz na consciência a auto-percepção pelo $e u$ da comoção que ele sofre, ela é a dor do trauma produzida quando o eu se defende contra o trauma, sendo a dor também, uma reação.

No trabalho de luto, a reação do eu contra a comoção desencadeada pela perda do outro se decompõe em dois movimentos: uma aspiração súbita da energia - movimento de desinvestimento - e a polarização de toda essa energia sobre uma única imagem psíquica movimento de superinvestimento. Isto quer dizer que, o eu desinveste a quase totalidade das suas representações para superinvestir pontualmente a única representação do amado que não existe mais.

A dor psíquica é, então, compreendida como sendo o afeto que exprime o esgotamento de um eu inteiramente ocupado em amar desesperadamente a imagem do amado perdido. O langor e o amor se fundem em dor pura.

O luto que se segue à morte do amado [não necessariamente o desaparecimento físico do amado, como já dissemos, mas a ruptura de uma imagem simbólica, que deverá ser desinvestida e re-significada] segue um movimento inverso ao da reação defensiva do eu.

Ao passo que a reação à dor consiste em um superinvestimento da dita representação, o trabalho de luto é o desinvestimento progressivo dessa representação.

Assim, realizar um luto significa, de fato, desinvestir pouco a pouco a representação saturada do amado perdido para torná-lo novamente conciliável com o conjunto da rede das representações egóicas.

“O luto não é nada mais do que uma lentíssima redistribuição da energia psíquica até então concentrada em uma única representação que era dominante e estranha ao eu" (NASIO, 1997, p.29). 
Na visão de Nasio (1997), o funcionamento do psiquismo se define pelo estado tolerável de insatisfação de um desejo que nunca chegará a realizar-se totalmente de modo que, enunciar que a tensão psíquica continua sempre viva e até penosa, que o desprazer domina ou que nossos desejos ficam insatisfeitos, não exprime de modo algum uma visão pessimista do homem, mas equivale a declarar que ao longo da nossa existência, estamos sempre em estado de carência, isto é, com um vazio sempre futuro que estimula o desejo e que é sinônimo de vida, pois o vazio é um pólo organizador do desejo.

Sem carência, esse núcleo atraente que é a insatisfação, o impulso circular do desejo, se perturbaria e então, só haveria dor, pois se a satisfação é demasiadamente trasbordante ou desmedida, o desejo perde o seu eixo e a dor aparece.

Assim, certo grau de insatisfação é vital para conservarmos a nossa consistência psíquica e para preservar a carência, isto é, mantê-la nos limites do suportável que o nosso parceiro intervém. Ele é o ser do nosso amor, que é capaz de fazer o papel de objeto insatisfatório do nosso desejo e, por isso mesmo, de pólo organizador desse desejo.

Desse modo, o amante eleito nos assegura a consistência psíquica pela insatisfação que ele faz nascer e não pela satisfação que ele proporciona.

O ser do nosso amor nos satisfaz, ao mesmo tempo em que excita o nosso desejo, ao qual não pode satisfazer por completo; proporciona-nos um gozo parcial e por isto mesmo, deixa-nos insatisfeitos.

O eleito amado ocupa um lugar essencial em nosso psiquismo: é aquele que faz com que nós sejamos o que somos e é aquele sem o qual, não seríamos nós mesmos.

O eleito amado é, ainda, a pessoa que nos seduz, isto é, que desperta e capta a força de nosso desejo e a qual progressivamente respondemos e nos apegamos até incorporá-la e fazer dela uma parte de nós mesmos, envolvida com uma multidão de imagens superpostas, cada uma delas carregada de amor, ódio ou angústia. 
Fixamos o amado, eleito inconscientemente, através de uma multidão de representações simbólicas, cada uma delas ligada a um aspecto do qual nos marcou.

Há um conjunto de imagens que liga o nosso ser à pessoa viva do amado até que ela seja transformada em duplo interno.

A essa sutura inconsciente do sujeito com a pessoa viva do amado, isto é, a liga de imagens e de significações vivificada pela força real do desejo que o amado suscita em nós, e que nele suscitamos, é o que nos une e o que o autor chama de fantasia do eleito.

A pessoa amada deixa de ser apenas uma instância exterior para viver também no interior, como um objeto fantasiado que re-centra nosso desejo tornando-o insatisfeito, no limite do tolerável.

Só captamos a realidade do eleito através da lente deformante da fantasia. Só o olhamos, escutamos, sentimos ou tocamos envolvidos no véu tecido pelas imagens nascidas da fusão complexa entre a sua imagem e a imagem de nós mesmos. Véu tecido também pelas representações simbólicas inconscientes, que delimitam estritamente o quadro do nosso laço de amor (NASIO, 1997, p. 41).

Quando amamos, amamos sempre um ser híbrido, constituído ao mesmo tempo pela pessoa exterior com que convivemos no exterior e pela presença fantasiada e inconsciente em nós. Reciprocamente, somos, para o ser amado, o mesmo ser misto feito de carne e de inconsciente. Assim, sofreremos outra dor, a do desaparecimento daquele que foi para nós o que fomos para ele: o eleito fantasiado.

Os objetos eleitos são ao mesmo tempo tão internos, tão íntimos, tão intrinsecamente ordenados pelo movimento do desejo, que vivemos sem perceber a solidez do seu enraizamento no inconsciente, de modo que somente quando somos ameaçados de perdê-lo ou depois de perdê-lo, a sua ausência revela dolorosamente a profundidade desse enraizamento.

Contudo, nessa visão, não é a ausência do outro que dói, são os efeitos em nós dessa ausência. Não sofremos com a falta do outro, mas sofremos porque a força do nosso 
desejo fica privada do excitante que a sensibilidade do corpo vivo do outro significava para nós. Sofremos porque o ritmo simbólico dessa força fica quebrado com o desaparecimento do compasso que as suas excitações escandiam. E sofremos também porque o espelho psíquico que refletia as nossas imagens desmorona por falta do apoio vivo em que o corpo do outro havia se transformado. Portanto, a lesão que provoca a dor psíquica não é o desaparecimento físico do ser amado, mas o transtorno interno gerado pela desarticulação da fantasia do amado. Desse modo, a dor psíquica ou dor de amar não é dor de perder, mas dor do caos das pulsões enlouquecidas. Em suma, o sentimento doloroso reflete não as oscilações regulares das pulsões, mas uma loucura da cadência pulsional. A dor psíquica é para Nasio (1997, p. 52):

a desorientação que sentimos quando, tendo perdido um ente querido, nós nos encontramos diante da mais extrema tensão interna, confrontados com um desejo louco no interior de nós mesmos, com uma espécie de loucura do interior que fica adormecida em nós, até que uma perda exterior venha arrancar os seus gritos de desespero.

Os mecanismos de defesa empreendidos pela colaboradora nessa trajetória existencial nos parecem necessários para que Isolda mantivesse a integridade do $e u$, tendo em vista a herança das concepções acerca do casamento, oriundas de sua família de origem de crença cristã, em outras palavras, exigências provenientes do supereu bem como uma atribuição de novos sentidos à existência do casal.

A partir da descrição de Isolda, compreendemos o quanto os ethos familiares e sócio-culturais ressoam os seus preceitos e paradoxos nas instâncias psíquicas individuais, construindo os supereus individuais e também uma estrutura emocional comum em um determinado grupo familiar. Essa construção psíquica grupal tem repercussões no modo como as pessoas re-significam as suas experiências cotidianas, os seus afetos.

Sendo assim, passaremos agora a apresentação de uma outra dimensão existencial do fenômeno re-significação do relacionamento amoroso e a reconstrução do prazer. 
Nesse processo de atribuir novos significados ao outro, à relação e, em conseqüência, ao próprio eu, Isolda desvela que o modo como percebia a sua inter-relação afetiva e sexual com Tristão assume novos sentidos, sendo a representação mental da sexualidade masculina para ela, re-desenhada:

parece que, depois que me contou isso [que havia lhe sido infiel], eu não sei, eu passei a senti-lo mais homem, eu comecei a enxergar ele de uma outra maneira, sabe? Como homem mesmo. Então, 'prá que ele não pudesse me trair mais, eu não sei se eu também me tornei ãh... eu passei a pensar também em mim. Mas a figura dele, ãh, passou a ser diferente 'prá mim, se tornou mais homem, ih, ele me empolgou mais ainda com isso, 'tá?

Percebemos com esse relato que um movimento de desinvestimento da representação psíquica do amado foi realizado, de modo que Isolda já é capaz de atribuir novos sentidos a imagem do parceiro e, em conseqüência a relação amorosa.

Além disso, o relato acima afirma mais uma vez que em meio à dor de uma insatisfação desmedida quando soube da infidelidade amorosa do parceiro, o eu retoma a pulsão sadomasoquista, sente prazer ao sofrer com a ruptura da imagem do outro e, simultaneamente, com a quebra do espelho narcísico, ao buscar se equilibrar, o que quer dizer que a colaboradora sofreu por ter sido traída, mas também obteve prazer nesse acontecimento.

Percebemos que a crença sócio-cultural que aceita a infidelidade do homem, que se torna tanto mais viril quanto mais parceiras sexuais tiver, faz morada entre as relações intra e extraconjugais que contam a história no palco em que Isolda vive.

O homem parece expressar sua masculinidade por meio da afirmação viril de ser o “caçador sexual”. Embora considere o marido mais viril e por isso, mais atraente, percebemos que o ressentimento é um dos sentimentos presentes nas vivencias relatadas pela colaboradora, como está subentendido nos dizeres abaixo: 
Realmente a situação da gente melhorou bastante, né ? Mas [ênfase] ah, não que o sentimento por vingança ficou, entendeu ? Mas eu, eu falei que a partir daquele momento desde que eu fiquei sabendo, eu também 'taria aberta 'prá [ênfase]..., sabe?, poder também sair sozinha ou sair com amigas, de ter uma liberdade, um pouco mais de espaço no relacionamento também, ah, porque até então, tudo era checado, também era uma pessoa que ficava muito em cima de tudo, o que eu fazia ah:: se eu saía com minhas amigas depois do trabalho ele não podia ficar com as crianças, eu falo que eu tinha que ficar em casa.

Esse relato manifesta o desejo de "vingança", de romper com o pacto pré-firmado de fidelidade conjugal, assim como o fez Tristão.

Não sabemos os caminhos percorridos por Isolda após conceder-nos o seu depoimento, se Isolda “traiu” ou “não” Tristão. Mas embora “querer vingar-se”, “pagandolhe na mesma moeda”, isso não se concretizara até o momento da entrevista.

Vale fazermos uma distinção entre a "mágoa” e a "vingança” que Isolda diz sentir, e o ressentimento, patente de seu relato.

Na perspectiva de Kehl (2004), o ressentimento nomeia a impossibilidade, ou melhor, a recusa que o indivíduo tem de se esquecer ou superar um agravo.

Ressentir-se significa atribuir a um outro a responsabilidade pelo que nos faz sofrer. Um outro a quem delegamos, em um momento anterior, o poder de decidir por nós, de modo a poder culpa-lo do que venha a fracassar. Neste aspecto, o ressentido pode ser tomado como o paradigma do neurótico, com sua servidão inconsciente e sua impossibilidade de implicar-se como sujeito do desejo (KEHL, 2004, p.11).

Assim o faz Isolda quando inicialmente atribui ao Outro eleito a culpa pela sua dor. Para Scheler (1912, apud KEHL, 2004), o “envenenamento psicológico”, como chama o ressentimento apresenta uma constelação afetiva que se compõe pela soma de rancor, mágoa, raiva, maldade, ciúme, inveja, malícia e desejo de vingança, tendo este último o papel predominante.

A lógica do ressentimento impede o impulso de se efetivar e o ofendido não se atreve, ou não se permite, responder à altura da ofensa recebida. O ressentimento se produz 
então, a partir da reorientação para o eu dos impulsos agressivos impedidos de descarga, o que gera uma disposição passiva para a queixa e para a acusação, bem como a impossibilidade de esquecer o agravo passado.

Na visão de Kehl (2004, p.13):

a culpa que o ressentido insiste em atribuir a um outro, responsável pelo agravo, é a face manifesta do sentimento inconsciente de culpa que o "envenenamento psíquico"- o retorno das pulsões agressivas sobre o eu produz. O ressentido é um vingativo que não se reconhece como tal.

Isso significa que movido pela própria culpa, o ressentido culpa o outro e ressentese, como vemos na vivência conjugal de Tristão e Isolda.

A perspectiva de Kehl (2004) afirma que para que o mecanismo do ressentimento ocorra é necessário que a vítima se sinta fraca para responder ao agressor, se sinta inferior à ele. Uma das condições centrais do ressentimento é que "o sujeito estabeleça uma relação de dependência infantil com um outro, supostamente poderoso, a quem caberia protegê-lo, premiar seus esforços, reconhecer seu valor” (KEHL, 2004, 13).

O ressentimento expressa, então, a recusa do sujeito em sair da dependência, a preferência por ser protegido, ainda que prejudicado, do que ser livre e desamparado.

O outro, nessa perspectiva, é representado pelas figuras que na infância tinham o poder de proteger, gratificar e punir a criança, isto é, aquele que recebe as demandas de amor e reconhecimento e que determina que o ressentido se represente enquanto um ser prejudicado e não um ser faltante.

Como já afirmou Sigmund Freud, as relações são sempre "transferenciais”, o que nos leva a indagar sobre o quanto de familiar existe nos “novos” enlaces amorosos que se constituem no decorrer da vida do sujeito e mais uma vez o que de "velho", conhecido, se faz atualizar entre as tramas intersubjetivas.

A mágoa, para Kehl (2004, p. 20): 
é a dor de uma ferida narcísica que ainda não deixou de sangrar. Pode ser comparada ao luto: tempo de reparação de uma perda, de desligamento da libido em relação a um objeto perdido, de reconstituição do narcisismo secundário depois de uma queda, uma perda, um fracasso. O trabalho de mágoa, como o do luto, requer recolhimento; ele incapacita a pessoa magoada para fazer novos investimentos, porque toda libido está concentrada na cicatrização da ferida.

Desse modo, enquanto o ressentido não concretiza a sua vingança, porque também culpa se, o magoado não a concretiza porque se encontra recolhido, incapacitado de realizar um novo investimento, vive somente para a sua dor, exaltando-a.

Kehl (2004), compara ainda o ressentimento com o ciúme, a alegria e a angústia, dizendo que ele não tem o caráter compulsivo e descontrolado como o ciúme, cujo caráter tão persecutório o sujeito não consegue evitar, não é espontâneo como a ira e a alegria e nem é inominável como a angústia.

Afirma ainda, que embora as queixas repetitivas do ressentimento não escapem à determinação do inconsciente, elas servem, acima de tudo, aos mecanismos de defesa do eu.

Agora, o vingativo que não se vinga e espera ser ressarcido pela justiça divina, sem implicar com seu desejo de vingança, está condenado ao ressentimento.

Desse modo, para se tornar um ressentido é necessário que o ofendido se mantenha em um eterno adiamento da resolução do agravo, sem se atrever a vingar-se e sem perdoar a ofensa, pois o perdão propicia o esquecimento e este só é possível se "as razões do responsável pela ofensa forem compreendidas ou se o ofendido conseguir superar o agravo até que suas conseqüências se tornem insignificantes” (KEHL, 2004, p.22).

A culpa que Isolda sente em relação à infidelidade do marido e a culpa que dirige a ele podem assim serem compreendidas como parte da dinâmica do ressentimento. Ao afirmar que “perdoou o marido, mas a mágoa fica...”, é claro para nós que estamos tratando aqui, do ressentimento. 
Em seu relato, Isolda versa sobre uma pretensiosa história a se re-construir:

depois de um tempo, eu comecei a me dar bem com ele, entendeu ? Só que claro, ah a gente perdoar eu acho que eu já perdoei porque eu acho que a traição, se foi fraqueza ou não, foi um momento dele, 'tá ? A gente 'tava ainda muito no começo de relacionamento, eu achei que dava prá se tentar ah:: resgatar ou passar por cima. Claro que jamais esquece tudo isso que é dito í [ênfase] uma traição jamais é esquecida. Eu acho que a mágoa fica, 'né ? Ainda tenho assim muita mágoa por ele ter feito isso comigo, mas ... eu acho que teve um perdão, teve um passar por cima, teve uma virada de página, entendeu ? Teve uma outra história na nossa vida.

Porém, quando a colaboradora diz que "teve um passar por cima [da infidelidade], teve uma virada de página [...] teve uma outra história na nossa vida”, essa re-significação existencial carrega as marcas do ressentimento, de um "gozo adiado e deslocado, porém nunca renunciado”. O que indica a presença do gozo é, para Kehl (2004), a repetição, a insistência na queixa e na acusação ressentidas, uma repetição determinada pelo sujeito do inconsciente.

Na visão de Eiguer (1998, p.40), o vínculo da transmissão psíquica entre as gerações veicula para a família:

um legado organizador, uma herança benévola, reparadora que contem uma parte maldita com a qual o individuo tentará coexistir ou lutar. Parte mal-dita nos diferentes sentidos do termo: portadora de maldição e de fatalidade, parte vergonhosa, fardo pesado e de obstrução. "Mal-dita" parece-me mais pertinente que "não-dita". Palavra mal enunciada, desgarrada, ruidosa.

Constatamos que Isolda busca a re-construção da relação amorosa, porém, cheia de ressentimentos, respostas aos apelos psíquicos de um eu individual que coexiste com uma psique familiar que dita normas, restrições, prescrições e estabelece planos em suas negociações intersubjetivas.

Nessa trajetória de re-construção do casamento, Isolda menciona outras dificuldades ou desilusões que assolaram a relação amorosa depois que Tristão lhe foi infiel. Ela diz que “... depois de alguns anos acabou envolvendo também ah::: assunto de 
separação porque o financeiro abalou até muito mais [ênfase] do que a traição”. Esse discurso revela que a infidelidade amorosa muitas vezes não é um fenômeno isolado, mas que se relaciona com outros complexos conjugais.

Como já dissemos, no momento em que colaboradora nos concedeu a sua descrição, Tristão estava desempregado há quase um ano. Isolda relata ter questionado nesse momento existencial sobre se deveria ou não permanecer casada com o marido desempregado. A partir disso, percebemos que embora o sistema hiper-consumista e hipercompetitivo situe a mulher cada vez mais no mercado de trabalho, uma inversão totalizante quanto às funções sócio-sexuais diferenciadas para homens e homens e pré-estabelecidas parece não ser desejável, como aponta o discurso da colaboradora.

Na vivência relatada por Isolda, o desemprego do homem, ou seja, a sua não contribuição no provimento doméstico desencadeia desilusões no casamento, afeta o projeto de vida afetivo-sexual do casal e sobrecarrega a mulher quanto as suas obrigações matrimoniais e/ou sociais.

Passaremos a seguir, a compreensão e interpretação da descrição da temporalidade de Bárbara frente ao fenômeno da infidelidade e da re-significação do relacionamento amoroso. 


\section{Bárbara}

Entrevista realizada em 26 de Fevereiro de 2004.

Bárbara tem 54 anos e seu parceiro tem 57, é casada há 34 anos no civil e no religioso, casou-se aos 20 anos e seu marido aos 23. Foi após 20 anos de casada aproximadamente, que Bárbara teve conhecimento de que seu marido lhe era infiel. A religião do casal é católica e o nível econômico da família corresponde à classe B1. Eles têm uma filha casada de 33 anos, um filho recém-separado de 28 anos, e uma filha solteira de 27 anos morando com eles. Bárbara e Antônio, seu marido, possuem ensino médio incompleto. Ela é dona-de-casa e ele é aposentado. Após Bárbara indagar do marido sobre a possibilidade dele ter um relacionamento com outra mulher fora do casamento, ele assume que suas relações extraconjugais se referem apenas às vivências sexuais com prostitutas e Bárbara revela em sua descrição a dificuldade em ter relações sexuais com o marido após esta descoberta.

Em sua descrição, Bárbara relata sobre algumas vivências na adolescência, na juventude e no namoro com Antônio, seu único namorado e atual marido, desvelando o desconhecimento frente as questões que a envolveram no âmbito da sexualidade. O seu 
discurso torna explícito, desse modo, o diálogo silencioso sobre a sexualidade no âmbito de sua família de origem e de seu meio social.

Bárbara relata: “A minha mãe, não, não, nunca, nunca, nunca, nunca” [ênfase] [a mãe nunca lhe falou sobre sexualidade]. Na adolescência algumas orientações que disseram respeito às questões sexuais foram recebidas pelo colégio de orientação católica que a colaboradora freqüentara, como vemos no relato abaixo:

... não existia cursinho de preparo [se refere à Educação Sexual]. Então teve uma vez uma palestra ... eh:::, no colégio das freiras aonde eu morava lá em CACA [nome de cidade], no Colégio GG [nome de colégio], teve uma palestra sobre o... falô... eh::: 'prá::: foi a única vez que eu fui, sube ... eu estudava lá, fiquei sabendo, falei prá minha mãe que ia ter uma reunião da escola tal, tal, e eu fui nessa palestra eh::: nessa palestra uma senhora casada ah, tantos anos ... "tome cuidado com o marido, com a casa, carinho, tudo tem carinho, a comida com amor tem sabor”, tal, tal, eu me lembro muito que ela comentou que ela lavava ... sabe o restinho de sabonete ? Ela lavava a camisa dele [do marido dela] com sabonetes, sabonete, tal, tal, essas coisas ... então ih, é ... foi aonde ...

Por meio dessa palestra a crença na responsabilidade da mulher quanto os cuidados com o marido é reafirmada, pois a colaboradora foi orientada sobre o modo como deveria se portar no casamento, cujos principais significados se referem "aos cuidados com os afazeres domésticos”.

Entretanto, embora não se falasse em sexualidade no lar de Bárbara, ela nos revela que qualquer conversa sobre esse tema foram tidas com o namorado, seu atual marido:

... o que eu ouvi, o que eu sabia, ele [o parceiro] que comentava comigo, quando eu 'tava namorando tinha um jeitinho de conversar baixinho, só os dois, então ele comentava, ele conversava comigo "que a gente ia casar, assim, assim ...", então eu perguntava ... Se você acredita, eu com dezoito anos, eu ... apesar de dezoito anos [ênfase], eu ficava imaginando por onde que nasce o nenên ... Entendeu ? Eu não sabia, olha só ! [ênfase], eu já cursava o ginásio. [...] Então, 'ce vê, depois já noivando que fomos entrar mais em assuntos assim, né? [em assuntos de sexualidade], ter mais liberdade porque eu não via mal nenhum, eu como noiva dele, de conversar, a gente conversava, conversava normal. Nunca ouvi falar nada e eu conversava com ele, foi onde eu perguntei 'prá ele e ele me 
explicou: "Por onde o nenê nasce?” "Por onde entrou 'prá se formar o nenê, o nenê sai por ali também”, né? Foi quando eu fiquei sabendo.

Saber "por onde nasce o nenê” significou para Bárbara “saber sobre a atividade sexual genital”, assunto que, permeado por tabus e interdições, ainda se mantinha desconhecido, secreto para ela, por volta de 1968. Essa vivência explicita a evidência entre a diferenciação entre os papéis de gêneros que foram demarcados pela divisão da sociedade em mundo público e privado, desde o início do capitalismo (Lins, 1997; Ariès, 1981; Chauí, 1991; entre outros).

Como já dissemos no Capítulo 1, quando a sociedade se dividiu em mundo público e privado, a mulher foi colocada no âmbito do lar, continuando o homem, no âmbito público dos negócios. Acentuou-se uma autoridade privada na família, na qual o ser masculino passou a ser o responsável exclusivo do provimento do lar e de seu domínio. Ao ser considerada angelical e assexuada, a mulher não deveria, portanto, receber informações ou orientações acerca das questões sexuais, enquanto que esse conhecimento deveria fazer parte apenas do universo masculino. Tais práticas são ressonantes nas vivências de Bárbara no casamento.

Embora as contracepções modernas, a descentralização do poder masculino, e uma maior liberação sexual tenham sido demarcadas fortemente pelas mulheres a partir da década de 70, encontramos na descrição dessa colaboradora o ethos que diferencia os papéis sociais e sexuais entre homens e mulheres, bem como a tentativa de controle e regulação da sexualidade, efetuada pelo lar e pela escola por intermédio da autoridade masculina e da regulação religiosa.

Se a partir da Idade Média o casamento definiu-se como o lugar legítimo para o uso dos prazeres, lugar demarcado pelos aspectos da genitalidade e da procriação, na atualidade essa regra está presente no discurso da colaboradora, que afirma ter sido somente na 
juventude, quando começa a namorar, que permite estabelecer um diálogo com o namorado sobre as suas vivências sexuais e as de seus semelhantes.

Continuando sua descrição, ao relatar sobre suas vivências no casamento, a colaboradora se refere a uma sobre a uma outra dimensão existencial do fenômeno, que diz respeito a sua relação afetiva e sexual com o parceiro, antes dele lhe ser infiel.

É interessante notarmos, que assim como marido de Isolda precisou morar separado da esposa por uma necessidade de trabalho, o marido de Bárbara também ficava em casa, restritos momentos, pois viajava a trabalho e dormia em hotéis em muitas ocasiões. Podemos dizer que nas vivências de ambas colaboradoras os momentos de afeto e de sexualidade não eram vividos em um contato diário.

Prosseguindo na compreensão da descrição de Bárbara, percebemos que a educação sexual recebida em sua adolescência e em sua juventude influenciou, mesmo que de modo escamoteado, o seu olhar e o seu comportamento frente às questões sexuais no casamento. Tais ressonâncias demarcaram o modo dela se comportar em relação ao parceiro, bem como o ideal de “felicidade” que deveria ser encontrado no casamento. Em sua descrição, ela diz: “...sempre procurei agradar, me agradar, ser carinhosa, muita higiene com a casa, com roupa, com meu corpo ... com tudo [ênfase]”, desvelando a transmissão de valores que foram "introjetados" pelo eu e que se referem a ensinamentos que recebera em sua trajetória.

Ao ser indagada sobre a vivência da sexualidade no casamento, Bárbara diz:

... eu nunca sentia nada [se refere ao prazer na relação sexual] eh::, eu nunca fui de falar "ah, eu senti isso”, ah::, também eu nunca fui de trocar segredos, ah:::, senti, deixei de sentir, nunca. Eu acho assim “ou eu vou num profissional, né?, ou eu vou ler um livro, não vou atrás de de revistas pornô [ênfase] ou procuro livros, né? Eu acho assim, eu quero bom pra mim, eu quero bom pra todos, então eu vou buscar coisa boa. Então eu também nunca comentei, apesar de ter muita liberdade com a Diná [amiga], mas eu não entrei em detalhes. 
Desvela que nunca sentira prazer nas relações sexuais com o parceiro e surpreendendo-se com o vivido no momento que nos concede a sua entrevista descritiva dizendo que nunca havia conversado sobre isso com ninguém. Compreendemos que "a ausência de ardor”, isto é, “o esfriamento na relação carnal” dentro do casamento são manifestações conseqüentes do fenômeno chamado repressão sexual, ao qual nossa sociedade ocidental foi submetida.

O discurso médico-científico afirmou, em sua origem, ainda mais a sublimação dos impulsos sexuais, a importância da monogamia no casamento e da indissolubilidade deste. Discurso que, embasado no saber religioso, ocupou-se da sexualidade por meio de objetivos normativos, concedendo à medicina o poder de regular os comportamentos e as atitudes frente ao sexual (Chauí, 1991).

Embora a colaboradora tenha relatado que até então, nunca havia falado com ninguém sobre suas insatisfações sexuais no casamento, ela desvela compreender o casamento e o saber medico-cientifico como lugares legítimos para se falar sobre a sexualidade. Contudo, embora conscientemente faça essa consideração, a colaboradora apresenta dificuldades em realizar uma passagem entre seu discurso e a sua prática, não sendo capaz de realmente abordar relevantes questões sobre a sua sexualidade, tais como a “ausência de prazer nas relações sexuais”, seja com o seu marido, o outro protagonista principal nessa história, seja com um profissional da área da saúde e/ou educação. Isso denota o quanto o fenômeno da repressão sexual trafega na atualidade.

No decorrer de sua descrição, Bárbara ainda diz que “embora não sentisse prazer sexual” ela tinha a percepção de que “agradava sexualmente o seu parceiro”, pois, afinal de contas, cumpria com suas obrigações conjugais, aquelas dirigidas aos cuidados com o marido, com o lar, com os filhos, bem como aquela referente ao dever de copulação. 
...assim como eu não sentia [se refere ao prazer sexual], mas eu, eu, procurei agradar eu sempre... de tudo, Edilaine, mesmo logo no começo de casada quando não tinha filhos, sempre fui de brincar, passar a mão nele [se refere ao genital do parceiro], fazer um carinho, brincava [ênfase]... sabe? Muitas vezes, quantas vezes eu pegava, pentiava ele [genital masculino], punha lacinho, brincava, eu brincava, eu tinha liberdade, eu não sabia ... eh::, eu não aprendi lá fora com ninguém. Eu, assunto de sexo vir saber foi com ele [com o marido], de uma forma normal porque minha mãe nunca comentou, jamais [ênfase], se ela via beijando pensava que já tinha acontecido [fala sobre a relação entre beijo e ato sexual]. [...] Eh, eh, então ... eu sempre brinquei, sempre tive liberdade, eh, gozação, brincadeira, dormir nós dormia assim de mão dada ou muitas vezes eu dormia punha a mão nele assim e ele punha em mim também [se refere aos órgãos genitais].

“Impossibilitada” pelo eu de sentir prazer sexual no casamento, a colaboradora infantiliza a vivência do erotismo no casamento, como demonstra o relato acima. Nesse palco, recalque, tal como elaborado por Sigmund Freud, tem um papel principal. Na teoria freudiana, o recalque constitui o núcleo original do inconsciente e designa o processo que visa manter nesta instância psíquica todas as idéias e representações ligadas às pulsões que, se concretizadas por produzirem prazer, afetariam o equilíbrio do funcionamento psicológico do indivíduo, transformando-se em fonte de desprazer (Roudinesco \& Plon, 1998). É nesse sentido, pois, que a colaboradora é impossibilidade de sentir prazer no ato sexual, pois o desprazer advindo da satisfação pulsional, colocaria em jogo a sua própria identidade feminina.

Prosseguindo, a colaboradora revela:

"Ele [o marido] sempre falou do meu corpo, sempre falou, sempre falou assim: "Ai, que gostoso ficar com a mulher limpinha, cheirosinha”, né?, corpo limpo, casa limpa, a comida mais sadia possível porque sempre fazia economia, por gostar de cozinhar, por e também por economia e agradar de tudo”.

E torna evidente uma relação estabelecida entre as denominadas “obrigações conjugais”, entre elas: a responsabilidade atribuída à esposa dos cuidados com a casa e com o marido, e as representações de feminilidade e sexualidade. 
Retomando Costa (1994), as identidades de gêneros constroem-se de acordo com o que uma determinada sociedade compreende, em um determinado momento, sobre o que é ser masculino e o que é ser feminino. Embora tenha havido uma flexibilização entre as relações sociais e de gêneros desde algumas décadas para cá, uma rígida distinção entre papéis femininos e masculinos se cristaliza na descrição de Bárbara. Na sua percepção, ser feminina significa proporcionar a satisfação do marido por meio do cumprimento do dever sexual, que é direito do marido, bem como mediante o cuidado com os afazeres domésticos, independentemente se a mulher obtém ou não satisfações nas relações sexuais.

No cristianismo, a santidade se liga ao sofrimento físico e psíquico, com o sacrifício da vida corporal, em detrimento da vida da alma. A descrição de Bárbara desvela a vivência de um “amor asséptico” numa relação em que o ardor carnal é pecado, capaz de sujar a pureza da alma. Estamos diante da dicotomia da mulher em duas figuras: a mulher casta e a mulher profana, sendo a mulher casta, a esposa ideal, a mulher "impossibilitada" de obter satisfação na relação carnal.

Prosseguindo em sua descrição, a colaboradora remete a uma outra dimensão fenomenal, a dinâmica da infidelidade e a sua relação com os filhos. Ao relatar sobre as suas vivências sexuais, Bárbara desvela o seu modo de se relacionar com os filhos no que diz respeito às questões sexuais.

É interessante notarmos que Isolda, cujos filhos ainda são pequenos, 09 e 10 anos, não faz referência a educação destes recebidas no casamento. No caso de Bárbara, ao relatar sobre a educação sexual dos filhos, ela desvela ao mesmo tempo sobre a sua própria sexualidade e as desilusões vividas frente às dificuldades que ela tem que enfrentar nesse aspecto inerente de sua existência que é a sexualidade. 
Desse modo, Bárbara afirma que sempre buscou se relacionar com os filhos de uma maneira diferente da que a sua família de origem se relacionou com ela, no que diz respeito às questões sexuais, como vemos no relato abaixo:

... criei meus filhos assim... O Padre Alfredo fala: “Criou certo”, eh:::, eh::: falar de sexo com seis anos, nove anos, conversava abertamente com as meninas sobre a menstruação, o meu filho quando eu percebi já crescendo ... "fiapinho", querendo levantar a voz, eu fui percebendo, o pai já conversou com as três crianças [ênfase], conversei de tudo e até com ele, com meu filho, sentava "vâmo conversar”, a mudança, 'tava vendo o que ia acontecer com o corpo dele [do filho], eu quis falar o que aconteceria depois e com as meninas foi a mesma coisa ... Então... eu sempre fui de brincar, de fazer gozação através de brincando, conversando, eu sempre falei de sexo aberto ... entendeu ? Então, o Padre Alfredo falou assim: “Ah, uma forma de de passar também, né ?”. "Vâmo sentar ali, não, vâmo falar de ler um livro”, é uma forma de passar. Eu sempre tomei banho perto dos meus filhos, ele perto das meninas também, a minha filha até já casada, tudo, tomando banho, tomando banho, às vezes fala "posso tomar banho com você, mãe?”, falam assim... até hoje as meninas... com o pai não, mas as meninas comigo sim, até os netos e o meu menino ...

Pautada no que é lícito e ilícito para o discurso religioso vigente, Bárbara encontra meios de lidar com a sexualidade dos filhos, no que diz respeito às modificações biológicas e fisiológicas vividas por eles na puberdade.

O período em que os filhos de Bárbara vivenciaram a infância e adolescência diverge, entretanto, do período em que demarcou a sua própria infância e adolescência. A colaboradora nascera na década de 50, período em que a identidade do homem e da mulher ainda se constituía de maneira estável, pautada por modelos regulamentadores de como ser homem e como ser mulher, como afirmam autores como Hall (2002) e Giddens (1993); a responsabilidade com os cuidados com os filhos era uma tarefa exclusivamente feminina, o divórcio era inexistente, e a indissolubilidade do casamento era um fator predominante na sociedade. Seus filhos, porém, nasceram na década de 70, período marcado por transformações significativas entre as relações intrafamiliares, bem como na própria 
Educação Sexual em decorrência de alguns fatores tais como a emancipação feminina e a reivindicação da mulher de prazer sexual (Giddens, 1993). Introduzido no Brasil em 1977, o divórcio incentivou o surgimento de novas formas relacionamento familiar, tais como abordamos no Capítulo 1, com as análises de Salém (1089) e Torres (2002), dentre outros. A partir desse período, a institucionalização das relações afetivas e sexuais entre homens e mulheres começou a se caracterizar pela heterogeneidade, que vem ganhar legitimidade social e cultural no momento em que vivemos agora.

Podemos dizer que a flexibilidade e a pluralidade nas relações sociais e familiares flexibilizaram também os valores morais, tal como percebemos no relato de Bárbara, quando nos relata que ela pode abordar com os filhos questões sexuais relevantes, tais como as transformações físicas e fisiológicas advindas da puberdade, período muito importante na existência humana.

Retomando Costa (1994), a formação da identidade de gênero e a construção da orientação afetiva e sexual na qual o indivíduo se reconhece como masculino ou feminino, tendo a sensação interna de ter a capacidade para se relacionar afetiva e/ou sexualmente com alguém de sexo igual ou oposto ao seu, ocorrem nessa fase da vida do indivíduo.

Prosseguindo em sua descrição, Bárbara se refere ao seu modo de lidar com o amor, a dor e o processo de luto, a partir da vivência da infidelidade de Antônio.

Bárbara descobriu que o parceiro lhe era infiel por intermédio de uma amiga, Marilise. Ela relatou a Bárbara que sua filha vira o “tio Toni”, seu marido, acompanhado de “uma moça loira e uma criança” em um local público na cidade em que moram. E a colaboradora revela como se sentiu ao receber essa notícia.

Nossa [ênfase] quando que... ela comentou, ela falou aquilo [ênfase] [infidelidade] eh::: é muito rápido .. nem sei situar frações de segundos, aquilo veio assim ... eu não sei te falar como que ... parece que afetou o cérebro, o corpo 
eh... quis faltar a voz, me ressecou a boca, a língua secou, sabe ?, me faltou o chão, não dá 'prá descrever, é uma sensação assim de segundo, mas que detona [ênfase], nossa quando veio assim aquela confirmação [da infidelidade] que ... senti aquela “coisa”, veio aquela “coisa” assim ... "será que ... que ele era tão sincero assim?”. Nossa [ênfase] e eu não quis demonstrar prá ela que eu fiquei abalada, procurei já brincar “ah, que não sei o quê...”, mas eu não sei se ela percebeu ou não, mas aquilo fal-tou o chão, de-to-nou [ênfase] água fervendo em cima de mim. Secou minha boca, minha garganta, o coração disparô, esquentô, gelô, fez tudo e ainda mesmo assim consegui recobrar os sentidos e brinquei “tal, tal”, né?, aí continuei, ficamos conversando até cinco horas, entrô na minha cabeça aquilo: sentado [ênfase], mesmo que seja amiga, que amiga é essa, né ?

Na visão forghieriana, enquanto seres humanos, somos capazes de "lançar-nos para fora”, isto é, de ultrapassarmos nossa existência imediata, como se pudéssemos experimentar uma sensação de que o tempo não é capaz de nos aprisionar.

No relato feito por Bárbara, compreendemos que no momento em que ela recebe a notícia sobre a infidelidade do parceiro, ela não é capaz de se situar enquanto um ser temporal e espacial. Diz que “não conseguiu situar-se no tempo”, que "Ihe faltou o chão” e que as "sensações” tidas naquele momento foram “indescritíveis”.

O temporalizar e o espacializar, ou seja, as atribuições de sentidos que concedemos ao tempo e ao espaço ocorrem mediante o trabalho de nossa percepção, por uma atividade pré-reflexiva. Ao compreendermos a descrição feita por Bárbara sob a ótica psicanalítica, percebemos que a "náusea" sentida por ela vai além das perdas das noções de tempo e de espaço e se refere à perda da identidade egóica.

É justamente a perda da própria imagem que leva o eu, nessa perspectiva, ao sentimento doloroso, pois é a percepção do eu sobre o tumulto interno desencadeado pela ruptura de nossas imagens idealizadas a geradora da “dor”.

Somos seres em co-existência com o mundo ao nosso redor e se encontramo-nos num sentimento de incompreensão acerca de uma determinada vivência imediata e sem 
referências sobre nossa própria identidade, sofremos conseqüentemente uma desestruturação temporal e espacial abarcadora de nosso ser.

Podemos apontar que a qualidade da dor psíquica vivenciada por Bárbara é a mesma daquela relatada por Isolda, a dor que se refere à ruptura da própria representação narcísica do eu.

Esse relato descrito por Bárbara revela também que as sensações fisiológicas que ela descreve, tais como “a falta de voz” ou “a falta de saliva”, são sintomas que manifestam a irrepresentabilidade da dor psíquica, que se encarna e é vivida pelo eu, bem como o empreendimento de um "mecanismo de defesa": a "negação”. Percebemos, pois, que no momento em que ela recebe a notícia, procura demonstrar para a amiga que "não compreendeu” e "nem se interessou” pelos sentidos presentes na mensagem enunciada, isto é, Bárbara “negou” a realidade sabida.

Ela relata em sua descrição que mesmo não conversando com a amiga sobre o teor da mensagem, foi questionar o marido sobre a veracidade da informação veiculada por ela. Cumpria, pois, um pacto de silêncio, um pacto que dizia respeito a manter as "conversas sexuais” no âmbito do casamento e não no âmbito social.

... eu não me lembro agora quanto tempo eu levei depois que eu levei esta bordoada aí [se refere ao recebimento da notícia da infidelidade]. [...] eu não me lembro afirmar com certeza se fiquei dias, se passou essa tarde, passou essa noite, no outro dia foi trabalhar... O que eu me lembro foi assim, ele veio de volta do NAZ [colégio em que os filhos estudavam], ele voltou em casa e eu estava preparada “vai ser agora, agora eu pego ele e jogo na parede”.

Percebemos ainda pelo relato acima que a colaboradora não conseguiu demarcar nem o tempo que permaneceu na casa de Marilise, nem o tempo que levou para abordar o marido sobre a notícia recebida. Bárbara encontrou-se sem território.

Prosseguindo, ela diz: 


\begin{abstract}
Aí na hora peguei... ele se embaraçou inteirinho, ele perdeu a cor, ele também é moreno, como eu, ficou pálido o rosto ... $\mathrm{o}$ semblante dele mudou completamente "ah:::”, eu gritei, eu gritava ,eu gritava, falei um mundo de coisa, falei um mundo de coisa e tal e tal e ele viu que eu fiquei fora de mim e falou “Ah, pelo amor de Deus, pára [ênfase], pára”. Não, que agora eu falei: "olha eh:::, vâmo resolver esse assunto. Que eu não posso ficar com isso aqui den-tro de mim, vai me matar”. Eu fiquei sabendo disso e eu consegui não sair do salto... só que eu fiquei procurando as causas, o por quê, não consegui saber: "quem será essa pessoa?” [...] o que eu queria não era bater no rosto, eu não senti nem vontade de bater no rosto dele, eu segurava como se eu tivesse sufocando ele mesmo, eu queria era sufocá [ênfase] ele naquela hora.
\end{abstract}

Bárbara relata ter "ficado fora de si" quando indagou do marido sobre a sua infidelidade. Sensações que se expressam no corpo são evidentes no relato acima e compõem o drama que se revela a traição. Compreendemos que, o desejo de “sufocamento" ao qual Bárbara se refere nesse discurso parece ser semelhante àquele sentido por ela mesma no momento em que Marilise lhe revelara sobre a infidelidade de Antônio.

Retomando a ótica de Nasio (1997), a dor psíquica se manifesta também como objeto e alvo do prazer sexual sadomasoquista, no qual a pulsão é carregada inicialmente pelo sadismo originário, isto é, pela agressividade, cujo objetivo é atormentar o outro, vencê-lo e dominá-lo. Num segundo momento, a tendência sado-agressiva volta-se para si mesma e o eu é capaz de experimentar verdadeiramente a dor e gozar de forma masoquista ao sofrê-la. Num terceiro momento, ao sentir a dor num alvo masoquista, retroativamente o alvo sádico secundário quer provocar a dor no outro e nesse tempo tendendo a alcançar a dor do outro, se obtém prazer com ela.

Nessa ótica, como já dissemos na compreensão-interpretação das vivências de Isolda, a dor é sempre masoquista, tal como percebemos também nos relatos dessa colaboradora. 
Na visão de Caruso (1986), a agressividade se manifesta enquanto fazendo parte da dinâmica do luto e o objeto amado corresponde a fortes expectativas do ideal do ego. Segundo a teoria freudiana, a expressão ideal do ego ou ideal do eu, foi criada para designar um modelo de referência do $e u$, que é produto da identificação com as figuras parentais e seus substitutos sociais. A partir desta idéia, dizemos que a idealidade corresponde àquilo que procuramos encontrar no outro com base numa construção primária de identificações com os pais e com outras figuras. Caruso (1986) explica que, ao ser ferido, o eu deve necessariamente se reconciliar com um ideal do ego abalado para que possa continuar a viver e isto implica, entretanto, na desvalorização da imagem do amado.

Tal como nos colocou Nasio (1997), a desvalorização do amado eleito se dá no trabalho de superinvestimento e desinvestimento dessa figura.

Segundo a perspectiva de Caruso (1986), é justamente nesse trajeto de desvalorizar o outro, ou seja, de superinvestir e superdesinvestir em sua imagem que a agressão aparece.

Continuando nessa perspectiva, o autor afirma que a separação produz na consciência um luto que desencadeia o surgimento do desespero, pois quando duas pessoas estavam fundidas numa união que tem como único modelo, a díade mãe-filho; a perda do objeto de amor, que é ao mesmo tempo um forte elemento de identificação, conduz a uma autêntica mutilação do próprio eu e provoca uma catástrofe na qual a identidade do sujeito se desestrutura. Essa desestruturação psíquica leva a uma considerável regressão que ameaça a integridade do $e u$.

Tal situação se mantém grave mesmo quando a união dual estiver supostamente mais voltada para o Id. Então, acionam-se imediatamente os mecanismos de defesa, para que a vitória da morte não se torne absoluta, para que a morte na consciência não aniquile a consciência (psicose) e para que, em prosseguimento a isso, não ocorra a extinção física (o morrer psicossomático ou suicídio) (CARUSO, 1986, p. 22).

Nesse processo, juntamente com os mecanismos de defesa, a agressão cria vida. 
Retomando a visão de Nasio (1997), é o eleito amado aquele que faz com que o eu seja o que é e sem o eu não seja ele mesmo. É aquele que capta a força do desejo do sujeito e que por isso faz com que este se apegue ao objeto de amor, até incorporá-lo e fazer dele uma parte única de si mesmo, envolvida com uma multidão de imagens superpostas, cada uma delas carregada de amor, ódio ou de angústia. Existe um conjunto de imagens que liga o ser de um sujeito à pessoa viva do amado, até que ela seja transformada em duplo interno.

Compreendemos a partir da descrição de Bárbara que, devido ao fato do amado ter vida em seu interior, como um duplo si, a colaboradora ao se surpreender com o amado, surpreende-se também consigo mesma e percebe-se "fora-de-si", perdendo todas as referências de identidade, de tempo e de espaço e manifesta a sensação de que vai “enlouquecer”. Compreendemos desse modo, que a descrição da colaboradora se transmite pela pura dor que, marcada pelo selo da subtaneidade e da imprevisibilidade, é inassimilável pelo eu e se impõe sem reservas, transformando todas as referências que a situam enquanto um ser em sintonia com o mundo exterior.

Antônio confessou à esposa que lhe foi infiel, e assim como fez Tristão a Isolda, relatou a ela que a mulher com a qual lhe traiu era uma prostituta.

Ao iniciar suas indagações sobre a traição, a colaboradora questionou sobre a sua relação com a moça que o acompanhava num ambiente público, tal como lhe informou Marilise. Antônio lhe disse que era uma amiga, “uma amiga casada”, mas Bárbara, ao duvidar do marido, o coage: "Você vai falar, eu não quero que você minta [ênfase] para mim. [...] “Quem é a vadia?... a vagabunda?”. E Antônio respondeu-lhe: “Não, é uma freguesa minha, eu fui uma vez lá trabalhar na casa dela e econtrâmo na FMU [local em que a filha de Marilise os viram] e comecâmo a conversar”. 
A colaboradora relata ainda ter insistido na confissão do marido e diante de sua agressividade, Antônio optou por assumir à esposa que havia tido uma relação extraconjugal.

Seguindo a ótica psicanalista, podemos afirmar quando Bárbara indaga de Antônio sobre “quem é essa mulher?”, mulher capaz de re-centrar o seu desejo, capaz de torná-lo infiel, que ela indaga justamente sobre "quem é ela mesma”. Ela busca compreender como se dá a traição, como o marido optou por estar com outra mulher que não era ela, quem ela é, já que não é mais quem pensava ser.

Como já dissemos, ao compreender e interpretar as vivências relatadas pela primeira colaboradora que apresentamos, percebemos que existimos sem que tomemos conta da solidez e do enraizamento dos objetos amados em nosso inconsciente, sendo que, somente na possibilidade de ausência destes, perdemos as referências de quem somos e com isso sofremos.

Antônio, porém, ao confessar à esposa que lhe foi infiel, deslocou toda a discussão do suposto encontro amoroso com "moça loira” tornado público na FMU para um outro encontro, revelando a Bárbara que havia estado “na zona”.

Sobre o recebimento dessa notícia de Antônio, a colaboradora nos relata: “aí eu fiquei ‘fera', eu gritava mais do que eu podia eu falei: você teve coragem... [ênfase], com toda a di-fi-cul-da-de [financeira] que a gente passa você teve coragem disso, de retirar dinheiro... da minha boca..., da boca dos filhos 'prá dar 'prá uma mulher?”. Compreendemos com o discurso de Bárbara que a traição assume o sentido de mercadoria, isto é, uma compra, uma posse, um desfrute e um pagamento pelo serviço.

Assim, como compreendemos mediante às vivências relatadas pela primeira colaboradora que apresentamos, o papel do "homem provedor do lar" tem suas facetas na dinâmica da infidelidade do casal. No caso de Isolda e Tristão, esse homem fora infiel 
também por não "pôr dinheiro em casa” quando ficara desempregado, mais que "pela traição amorosa”, como nos disse a colaboradora. No caso de Bárbara e Antônio, esse homem fora infiel também ao "deslocar o dinheiro do lar para a casa de prostituição”, e não somente quando manteve relações sexuais fora do casamento.

Mais adiante em sua descrição vemos que, várias foram as indagações que a colaboradora fez a Antonio, isto é, fez a si mesma, em relação aos sentidos e significados presentes na infidelidade, tais como seguem no relato abaixo:

"O quê levou você a isso? O quê te falta? O quê você quer? Que eu minta coisas pra você, 'prá você fantasiar na sua cabeça?”. Continuando ela diz: “Eu não vou nunca, jamais, eu não vou eh:: fazer... fortalecer, alimentar as fantasias suas. Eu não posso, eu não posso me rebaixar, uma mulher que tem vergonha, dignidade, ela não pode se rebaixar... a ponto de de alimentar as fantasias do marido. Ou você tem alguma fantasia que você precisou também ir na zona? ”.

Podemos retomar as vivências de Isolda e re-lembrarmos que entre todas as possibilidades de lançar-se existencialmente, tão diferente de Bárbara, ela desejou, por meio da fantasia, vivenciar ou ocupar o lugar da prostituta na relação com o marido. A partir do relato acima, compreendemos que Bárbara, ao contrário, buscou afirmar suas diferenças existenciais com a prostituta.

Em sua percepção imediata, Bárbara compreende que o seu papel social e sexual de “mulher de família” é essencialmente distinto do papel exercido pela prostituta que satisfaz sexualmente aos homens a troco de dinheiro.

Esse discurso re-desenha a persistência da existência da dupla moral que ao se constituir enquanto um dos responsáveis pela separação entre amor e o sexo dicotomizou a representação da mulher na figura da "santa” e da "prostituta” e incentivou, assim, a prática sexual dos homens com as prostitutas.

Prosseguindo nos trajetos de Bárbara, vemos que ela pedira ao marido que não apenas realizasse a confissão da infidelidade, como também descrevesse como foi o 
encontro com a prostituta. Vale lembrarmos que essa mesma atitude, exigir ao marido sua confissão e o relato sobre o encontro sexual, também fora assumida por Isolda.

Ao retomarmos Salém (1989), podemos dizer que é comum a expressão da necessidade de conhecer o que o outro faz fora do casamento, principalmente entre os casais contemporâneos; como se esse conhecimento amenizasse o drama que pode advir de qualquer situação vivida pelo(a) parceiro(a), da qual o(a) cônjuge é excluído. Podemos dizer que o drama da infidelidade revela uma ruptura da fantasia primária de desejo de união entre dois seres, ou seja, se refere a uma transferência da acalentadora vivência de união entre mãe e bebê, vivida em nossos primeiros anos de vida e que se repete em todas as relações afetivas que estabelecemos posteriormente ao nosso nascimento, ao longo de nossa existência.

A terceira pessoa, numa díade amorosa, parece surgir como uma ameaça, um objeto destruidor da união da dupla. Segundo Heilbrorn (1980 apud Salem, 1989), a tentativa de uma resolução para infidelidade amorosa se dá por meio de um mecanismo que tem por fim "a introdução e inclusão do outro cônjuge em uma experiência da qual ele havia sido inicialmente excluído” (SALEM, 1989, p.33). O autor chamou esse mecanismo que permite a um dos parceiros tomar conhecimento sobre as atitudes todas fora da relação do casal, "fidelidade confessional" e tal como compreendemos os discursos de Bárbara e Isolda na relação de ambas, esse mecanismo se processa.

Apresentamos abaixo sobre as descrições que Antônio fez a Bárbara acerca do encontro que ele teve com a prostituta:

... ele disse que ia com os amigos, saía do serviço... "Mas por quê? Quê te levou...?” E eu gritando “ah::: meus amigos falando, falando”. “Ah:::, como um menino de colegial, um menininho que pela primeira vez que viu alguém mais velho ou algum amigo da mesma idade que foi, contou e você ficou assim “floriando”, teve que ir lá 'prá ver? Sendo que você teve a sua vida de solteiro, precisava depois de casado?... vai saber quantas vezes?”. “Mas só essa vez”. 
“Não sei se foi só essa vez, eu não ‘tava junto” e aí eu falei: "agora você vai contar 'prá mim tim-tim por tim-tim.

Ao ter dado continuidade à “inquisição”, o eu narcísico, todo ferido, disse a Antônio:

Você teve coragem... de um membro [ênfase] teu colocar dentro de outra pessoa?, você não se sentiu mal, sujo, nojento, sei lá?’[...] você beijou a boca dessa pessoa 'prá encostar na minha boca? Na boca da sua neta?”. “É, beijar nós não bejâmo, ela queria, mas eu não deixei”. E eu falei assim: "você conseguiu...?”, porque 'pró homem... a visão do homem é diferente da nossa. Hoje eu sei que eh::: ... jamais 'cê [a mulher] conseguiria se fosse 'prá fazer ... [atividade sexual] com outra pessoa .... eu ia imaginar meu marido..., entendeu? Eh:::: eu digo assim: "a dificuldade de ter ereção”, ele falou: "não, não, eu imaginei que era você que "tava ali". "Você teve coragem de me usar [ênfase] ainda? Embaixo de você era uma "mulher de zona” que ‘tava ali!”. [...] "Não, não toca no meu corpo, você não é digno de tocar no meu corpo. Eu sou mulher só ‘prá você, eu não sou mulher 'prá vários homens, então você esta quebrando o que prometeu um dia na Igreja que é a fidelidade e fidelidade, em todos os sentidos".

Na perspectiva freudiana, o termo “narcisista” se refere àqueles indivíduos que tomam a si mesmos como objetos sexuais e não aceita desse modo, que nenhum outro seja melhor que ele mesmo, tal como percebemos no relato acima quando a colaboradora se compara à prostituta.

Em nossa trajetória existencial deparamo-nos com uma gama infinita de possibilidades de nos identificarmos com os outros seres humanos, seja em seus aspectos físicos, ideológicos, afetivos, morais, sexuais, dentre outros.

No discurso da colaboradora, ela nos relata que Antonio imaginara estar com a esposa quando mantinha relações sexuais com a prostituta, porém, Bárbara o condenou por lhe ter comparado a uma "mulher da vida”, percebendo-se como um ser superior a ela. Pelo que pudemos compreender com esse relato, Antônio parece ter tendido a representar a figura feminina, um objeto de prazer, seja ela a esposa ou a prostituta. 
Na seqüência, Bárbara revela que ficou revoltada com a ocorrência da infidelidade de Antônio, já que ela sempre cumprira com suas obrigações matrimoniais, como podemos perceber no relato abaixo:

“... de tudo, de tudo que eu procuro fazer: roupa [ênfase], costurar roupa nova aqui em casa, pão feito em casa, macarrão feito em casa, tudo, tudo [ênfase], o que eu posso fazer 'prá economizar, você retirar de nós esse dinheiro 'prá levar 'prá uma mulher que ganha a vida com facilidade vendendo o corpo ... [pausa]?” [...] Ele falou: "coitada”. "Coitada [ênfase], elas são coitadas? São porque quiserem fazer o que quiseram na juventude e foram parar lá?, desobedecer os pais?, elas são coitadas?

Podemos compreender com esse relato que a colaboradora se sente injustiçada por ter exercido a sua função de esposa "como manda o figurino” e, em retribuição, o marido lhe tenha sido infiel, isto é, não tenha cumprido com o pacto nupcial de fidelidade do amor.

Continuando no caminho de compreender e interpretar sua história, percebemos que a colaboradora acabara por se surpreender com o próprio dito: “os coitados somos nós 'a maior prostituta [ênfase]’, eu falei ‘prá ele, ‘a maior prostituta é a própria esposa...” porque ela não ganha [realiza um trabalho sem remuneração monetária] e o marido eh::: não é tão amante assim 'prá ... 'prá ... ser completo”, pois percebemos com esse relato que enquanto seres que compartilham do mesmo universo existencial, somos capazes de nos identificarmos, a qualquer momento, com qualquer um de nossos semelhantes.

Bárbara, numa aproximação entre ela e a prostituta, torna-se capaz de se identificar com ela e perceber-se enquanto um ser feminino submetido aos desejos e exigências do ser masculino. Essa identificação é possível, seja para uma “mulher da vida fácil” ou para “uma mãe de família”.

Ao recriminar o marido por lhe ter sido infiel a colaboradora afirma: ““prá pessoa ser completa ela vem caminhando desde o namoro com Deus, amizade com Deus, um propósito com Deus dentro do casamento, aí sim, pois ao contrário, é assim: “vai levar da 
vida”, o que nos leva a compreender que Bárbara se decepciona com o rompimento do pacto religioso de fidelidade recíproca firmado no casamento.

Nessa trajetória de compreensão da história de vida da colaboradora, percebemos também que ela exercitara a partir dessa significativa vivência de dor e traição, uma reflexão acerca de sua existência no meio familiar de origem.

Ao relembrar a relação afetivo-sexual dos pais, a colaboradora nos revela:

\begin{abstract}
Com o meu pai e minha mãe, eu vi muitas assim... brigas e discussões assim, até .... levantar a mão, "ciumera”, ver minha mãe cheirar a roupa do meu pai, achar marca de batão, fio de cabelo que não tinha nada haver dele. Então eu, quando me casei eu pedi muito assim prá Jesus eh::: [..] eu fiz esse propósito com Jesus: “A vida que minha mãe levou com meu pai...” nunca me preocupei em cheirar a roupa dele [se refere à roupa do marido], ver se tem marca de batão, mexer na gaveta, revistar carteira, até eu descobrir, né ? [...] Acho que minha mãe devia ter muito ciúmes também e ela tinha muito ciúmes e meu pai talvez até procurar fora já era aquele tempo comum ser assim, né? Então, eu tive como propósito: “Não quero prá minha vida o que minha mãe e meu pai viveram [se refere à infidelidade do pai, às brigas e discussões entre o casal]" [...] Porque comentei isso, que falei com Jesus tão verdadeiramente que também não fiquei assim [...] eu falei: “não vou ficar examinando”.
\end{abstract}

Pela ótica psicanalítica, compreendemos que a vida psíquica familiar é transmitida de geração para geração, aos membros da família (Berenstein, 1988; Eiguer, 1998;).

No relato acima, observamos a percepção que a colaboradora tem acerca da suposta infidelidade do pai: "a sua mãe era muito ciumenta e talvez por isso o pai procurava mulher fora de casa” e, além disso, os significados atribuídos à infidelidade dele: “era comum naquela época que o exercício da sexualidade fosse também efetivo fora do lar”.

Compreendemos que fora transmitido a Babara que, apesar de naturalmente fazer parte da dinâmica familiar, tanto a traição masculina quanto o ciúme parecem engendrar desavenças no núcleo familiar. 
Assim, ao ver a mãe sofrer no casamento, na realidade, a colaboradora desejara não ter vivenciado em seu casamento, a infidelidade do parceiro.

Contudo, seus desejos foram em vão e assim a história da mãe se repete no casamento de Bárbara: Antônio lhe é infiel e cabe a ela tolerar a infidelidade no casamento, sem se separar do marido traidor.

Ainda nessa visão, Eiguer (1998) afirma que a representação inconsciente de um ancestral pode estar presente ao menos em três gerações, de modo que as crenças, a moral, os costumes, os mitos, bem como os vínculos e os papéis sociais são transmitidos de uns aos outros, podendo estes ser totalmente aceitos, ou não.

Desse modo, percebemos que apesar da colaboradora não se separar do marido, ela também não aceita a infidelidade, numa constante repetição da história familiar. Embora tenha desejado não ter sido traída no casamento como fora a sua mãe, ela assume essencialmente o mesmo papel “de mulher submissa” que já fora representado pela mãe de sua mãe, aquele da mulher que continua casada, convivendo no casamento com tantos desencantos e desencontros.

Bárbara nos relata que por ter feito uma pacto com Jesus, pedindo a Ele que preservasse seu casamento da infidelidade, ela acreditava na certeza de que a fidelidade era recíproca em seu casamento, e ela a única e exclusiva mulher na vida de Antônio. Revelanos, então, que conforme os anos foram se passando, Antônio trabalhava mais fora do que em XX [cidade em que moram] e que algumas situações lhe traziam indícios sobre a sua infidelidade. Negava, porém, que na realidade isso pudesse acontecer. "Nunca me preocupei, sempre me preocupei se chegasse tarde por isso por isso que desconfiei, sempre procurei agradar, me agradar [...] então... nunca me levei por brincadeira...”. Num jogo de palavras percebemos nesse relato que se por um lado, Bárbara tentava negar qualquer possibilidade do marido lhe ser infiel, por outro, seu inconsciente queria mostrar a 
possibilidade de lhe ser infiel. O relato expressa assim, a existência de um "ato falho" que se manifesta numa contradição entre confiar e desconfiar da fidelidade de Antônio.

Na visão psicanalítica, o "ato falho" diz respeito aos atos nos quais o sujeito, a despeito de si mesmo, substitui um projeto ou um verbo ao qual visava por uma ação, conduta ou fala que até então era para ele mesmo desconhecida, imprevista. Podemos dizer que desse modo, é na própria vivência intencional que, embora a colaboradora acreditasse que o marido era a ela infiel, ela descobre que essa "verdade" para si mesma, duvidosa. Continuando ela diz: "Sabe quando fica dentro de você assim: "você acreditou” [ênfase], mas por outro lado, algo mais forte fala dentro de você: “será verdade?””. Mas também não fiz disso aí [a percepção da infidelidade dele] uma batalha ...”, desvelando a contradição de suas percepções.

O “saber inconsciente” sobre a infidelidade de Antônio desvelou-se numa vivência pré-reflexiva, e retomando a perspectiva psicanalítica, podemos afirmar que esse saber, veiculado pela atividade do inconsciente, é construído por elementos tanto conscientes, quanto pré-conscientes e inconscientes que são transmitidos de um indivíduo a outro, de um grupo de indivíduos a outro por meio de um processo denominado de interfantasmatização (Eiguer, 1985).

Na visão desse autor, o grupo familiar apresenta desde o seu início uma grande complexidade interfantasmática, que se traduz na junção de sentimentos, temores, expectativas e fantasias comuns aos membros de um mesmo complexo familiar. Assim, cada grupo familiar apresenta uma ressonância interfantasmática entre seus membros que demarca a matriz de todo o funcionamento inconsciente da família. Sendo assim, a infidelidade vivida na família de origem da colaboradora ultrapassa esse núcleo familiar e faz com que a colaboradora vivencie em sua relação afetivo-sexual, sentimentos experimentados em sua família de origem. 
Retomando as vivências da colaboradora explicitadas até esse momento, seja em seu casamento ou no âmbito de sua família de origem, percebemos que as atitudes assumidas por ela são uma expressão consoante com os princípios cristãos, ou seja, a expressão de uma postura coerente com a crença católica acerca do juramento recíproco de fidelidade conjugal firmado no ato do casamento e que envolve toda a construção de um psiquismo familiar único e que tende a regular normas prescritas que devem ser seguidas. Para Berenstein (1988, p. 63):

Certos aspectos da estrutura inconsciente de um grupo familiar são explicitados como normas e embora se originem na história do grupo, continuam a regula-lo na atualidade e têm vigência e eficácia embora suas fontes sejam desconhecidas para os membros do grupo, assim como o são também condições atuais que as mantém. Estes núcleos históricos consistem em expressões verbais mantidas através do tempo, símbolos, mitos familiares, todos integrantes da cultura familiar. Estas formações conservam-se, às vezes, desde tempos longínquos e estão dotadas de uma forte coesão: continuam a circular na história familiar apesar das difíceis incongruências que freqüentemente colocam para a organização familiar”.

Essa afirmação explica as incongruências que ganham vida nas vivências relatadas pela colaboradora, dentre muitas outras, a incoerência entre a percepção de que a infidelidade masculina era "natural” na época em que seus pais foram casados e a sua não aceitação em seu próprio casamento e a incoerência entre manter-se casada, mas não obrigar-se mais a cumprir o dever matrimonial de copulação, o qual abordaremos mais adiante.

Os traços históricos familiares podem persistir disfarçados e combinados com outros da mesma época ou de épocas posteriores e estes são muitas vezes, na ótica de Berenstein (1988), propostos por um membro de um grupo familiar, em nome de um denominador comum: o grupo. Desse modo, a temporalidade do inconsciente permeia o dito e a ação de normas pré-estabelecidas nos núcleos familiares, como por exemplo, a permissão da infidelidade masculina em detrimento da infidelidade feminina. 
Percebemos também que a partir da vivência da infidelidade do parceiro, assim como Isolda, Bárbara torna conscientes os desencantamentos que compõem a vida-a-dois no casamento.

A colaboradora faz referência a uma outra dimensão existencial do fenômeno: a re-

\section{significação do relacionamento amoroso: o aprisionamento da dor.}

Como vimos, Bárbara revelou sempre ter tido dificuldades no que diz respeito à vivência de sua sexualidade no casamento. Entretanto, ela revela ainda que embora tenham se passado quatorze anos da descoberta de que Antônio lhe era infiel, ela ainda se recusa a ter relações sexuais com ele, como está explicitado no relato abaixo:

\footnotetext{
Ficou assim, tudo, essa época de lá pra cá se tornou difícil... muito difícil ... eu nunca comentei eh:::, eu falei pra ele, mas eu sofri, eu sofri com tudo ... eh, e eu tive tanta força, Edilaine, que eh:::, eu devo, eu levantei ele assim [se refere ao momento em que o indagou sobre a infidelidade], ele é forte, eu levantei, tanta força naquela hora: "não toca mais em mim, você vai ter que ser digno, você vai ter que provar prá Deus e 'prá você porque digno você não é”. Na cabeça da gente passa assim: “é como que... como pode ? Como pode?” Só assim: ... “como pode?”, eu lembro... que você imagina, você com seu marido e ele contando e eu imaginado o momento de lá e eu me imaginando aqui [...]. É muito ruim, é mal, é ruim tanto no primeiro momento lá com a menina, que a minha amiga comentou [se refere ao momento em que a amiga lhe revelou a infidelidade amorosa de Antonio] e esse então [se refere ao momento em que o marido conta que teve relação sexual com uma prostituta], de toda forma ah::: e então é diferente porque é uma pessoa que já é casada, é nojento. Você é nojento, de nojo lá e nojo cá, também com a outra, com “a mulher da vida”, então foi muito difícil, né?
}

Compreendemos que desiludida com a infidelidade do parceiro, a colaboradora utiliza um "mecanismo de defesa" denominado pela teoria freudiana como "repressão" pedindo a ele "que não toque mais nela”, utilizando-se, pois, de uma operação psíquica que tende a suprimir conscientemente uma conduta, uma idéia ou um afeto, cujo conteúdo, ter relações sexuais com Bárbara, é desagradável. 
Prosseguindo em sua descrição, ela relata:

... então, eu achava assim, quer dizer, o meu jeito de ser parecia que então completava [se refere ao parceiro, à relação sexual com o parceiro], não importava, eu nunca 'tão assim, Edilaine, eu não me preocupei eh, eh, mesmo se ele viesse, tivesse relação comigo, movimentar e daqui à pouco vai pró prazer dele e acabô, eu nunca me preocupava com isso.

Como já afirmamos, a percepção de si mesma era para Bárbara até o momento em que Antônio lhe trai, a de uma mulher que cumpria adequadamente o desempenho de seu papel feminino: esposa, mãe e mulher que nunca descuidara do lar, dos filhos e da satisfação sexual do marido, sem se importar com o seu próprio prazer sexual. Desse modo, percebemos que Bárbara não tinha até então refletido sobre suas vivências afetivas e sexuais no relacionamento a dois, como percebemos no seguinte relato: "Nunca levei 'prá esse lado... eu pensava comigo, eu pensava assim comigo às vezes: ‘eu não sinto ou eu... sou, tenho algum problema, sou frígida', é essa palavra?”. Podemos afirmar que uma cortina se abre em seu palco existencial e descobre vários sentidos referentes à dinâmica conjugal.

Ela ainda diz: “eu penso [ênfase], fui tão perfeitinha, né? Perfeição não existe, né? Mas o máximo que eu fiz foi de bom [ênfase] e no fundo você não 'tá é fazendo é nada”, e desvela que por mais que tenha buscado ser a mulher ideal para seu par, já que cumpria suas obrigações maritais adequadamente, ela não era nem ideal, nem exclusiva, não era “tão perfeita” como acreditava ser e ainda se deu conta da existência de suas insatisfações sexuais na vivência conjugal.

E retoma as insatisfações sexuais no casamento:

“Achava que 'um dia a 'engrenagem' vai ser encaixada” [expressa o desejo de obter satisfação na relação sexual com o marido]'. Então, depois disso [da infidelidade] ficou muito difícil porque eu falava: ‘pôxa vida, né ?[...] detonou 
tudo, então se tornou difícil a parte sexual. Quando aconteceu [a infidelidade],tentei ao máximo desligar a parte sexual”.

E se recusa a ter relações sexuais com ele, “dando lhe o troco”, rompendo o pacto de compartilhar com ele todas as vivências que deveriam ser do casal, tal como ele o fez. E ainda prossegue dizendo como Antônio se sente frente as suas atitudes:

“por quê que você chora?”. [o marido lhe perguntava]. Então, acabou, ficando estranho, eu creio que ele falou a verdade que se eu tivesse realmente perdoado, eu, ei diante de Deus, mesmo assim, né ?, 'tava perdoado. Eu sei que ele pediu três vezes, que ele sentiu, ainda brinco, converso tudo, faço brincadeira. [...] “isso [a relação sexual] se tornou um medo 'prá mim. [...] eu acho que é necessário [o sexo é necessário] só que criou uma barreira, tem uma barreira, ele me pediu perdão de todo coração e o homem consegue "virar a página” com muita facilidade. “Ah, foi aquilo lá, é maquinamente, aquilo lá é uma coisa mecânica, entendeu? Isso que eu quero que você entenda, eu te pedi perdão, eu ti perdi perdão de coração, é uma coisa diferente, é como um trabalho aquilo ali e tal”. E 'prá mulher não é assim, nossa, você não consegue... O que ficou foi é esta assim esse gelo, essa pedra de gelo [ênfase], o que não passa, o que passa pela cabeça foi que “eu não perdoei”, ele fala “você não perdoou, Bárbara”.

Percebemos que assim como Isolda, Bárbara se ressente, insiste na manutenção ativa de uma repetição, uma repetição de frisar que o outro lhe ofendeu. Retomando a perspectiva de Kelh (2004, p.12), ressaltamos: “O ressentido não é alguém incapaz de se esquecer ou de perdoar; é um que não quer se esquecer, ou que quer não se esquecer, não perdoar, não deixar barato o mal que o vitimou” e assim, se difere do raivoso, pois a raiva, tal como a decepção, tem prazo de validade e se resolve com a vingança ou com o perdão.

Bárbara relata que Antônio diz “que ela não o perdoara”. Consciente disso, deixa ceder-se pelo ressentimento. Contudo, afirma que "um dia” pretende modificar essa situação, ou seja, "pretende perdoar" o marido e voltar a se relacionar com ele eroticamente. Relata ainda buscar a ajuda de sua psicoterapeuta nessa tarefa, como podemos notar no relato abaixo: 
Como a Dra. [psicoterapeuta] colocou, nós vamos mudar. Vamos no cinema de mãos dada, conversa... já falei isso várias vezes. Ele fala: “isso [não ter relação sexual] faz mal 'prá você, tá fazendo mal 'prá você, 'tá fazendo mal para a nossa vida. [...] Ela [a psicoterapeuta] e eu, nós duas trabalhando, ela trabalhando comigo aqui a ponto de trazer ele aqui 'prá gente 'tar trabalhando ... Ele veio [veio ao consultório], a ponto de um homem chegar: “vâmo conversar ...”. Mas não tem dado tempo, menina! Outro dia ele veio aqui falar com ela, passa assim agora na minha cabeça, eu penso assim... "que vai melhorar”.

Até que “esse dia” chegar, o impulso masoquista toma conta da relação do casal, o trabalho de luto é interminável e a relação afetivo-sexual no casamento não se reconstrói. Na lógica da repetição, os mesmos amargos e significativos sentimentos desencadeados com a prática da infidelidade amorosa de Antonio se mantêm presentes e o eu insiste na dinâmica do ressentimento. Realizar o “trabalho de luto”, como já dissemos, significa de fato, desinvestir pouco a pouco uma representação de uma imagem saturada para criar uma nova imagem conciliável com um novo conjunto na rede das representações egóicas (Nasio, 1997). Quando o trabalho de desinvestimento de uma imagem não se cumpre, o eu fica imobilizado em uma representação coagulada e o "luto" se eterniza em um estado crônico que pode paralisar a vida da pessoa enlutada durante vários anos, ou até mesmo durante toda a sua existência, caracterizando-se patologicamente.

Sendo assim, paralisada num acontecimento eternizado, a colaboradora adia a possibilidade de um novo encontro amoroso com o parceiro e apesar de terem se passado quatorze desde a descoberta de que Antônio lhe traia, Bárbara mantém viva a promessa que fez no momento dessa descoberta: “se afastar sexualmente dele”.

Passaremos a seguir, à compreensão e interpretação da descrição da temporalidade de Stela frente ao fenômeno da infidelidade e da re-significação do relacionamento amoroso. 


\section{STELA}

Entrevista realizada em 09 de Março de 2004.

Stela tem 47 anos e seu parceiro 53, é casada há 29 anos no civil e no religioso, casou-se aos 18 anos e seu marido aos 24. É católica e Paulo seu marido é ateu. Ambos possuem ensino fundamental incompleto, sendo ela dona-de-casa e ele aposentado. O nível econômico da família corresponde à classe C. Eles têm uma filha de 27 anos e dois filhos com idades de 18 e 15 anos. Stela relata que durante toda a sua trajetória ao lado de Paulo ele lhe fora infiel, num casamento permeado por agressões físicas e morais. Revela ter contraído do marido uma doença sexualmente transmissível - DST- chamada HPV, causada pelo papilomavírus humano que acarreta uma série de sintomas, tais como lesões na parede da vagina, bem como coceiras, ardores, secreções e dores, podendo contribuir para o surgimento de câncer de útero e infecções em outros órgãos na mulher. Stela relata que se sente deprimida e adoecida e que embora tenha desejado várias vezes se separar do parceiro, este a ameaça de morte, caso se separe dele.

Em sua descrição, Stela relata acerca de sua vivência na juventude, revelando ter namorado somente Paulo, seu atual marido.

quando a gente namorava, ele era uma pessoa maravilhosa, ele não deixava .. vamos supor, olha, o namorado da minha irmã dava uma pulseira 'prá ela, ele dava meia-dúzia, na época eu trabalhava de empregada doméstica não pude concluir meus estudos 'prá poder ajudar minha mãe ih::: ele, como ganhava bem, bem melhor do que eu e eu tinha que dar o dinheiro 'prá minha mãe, minha irmã ganhava bolsa, ele dava a bolsa e o porta níquel, cigarreira, sabe? Tudo o que minha irmã ganhasse do namorado, ele me dava em dobro, ele queria me amparar, me proteger com os braços dele de tudo e de todos, nunca mostrou ciúmes, nunca mostrou ciúmes, só que depois que eu me casei com ele ... de tudo, essa bondade, essa coisa a gente dizia que fulano bateu na mulher, ele dizia que jamais ia fazer isso, que "não se bate em mulher, que mulher é como uma flor”. 
Seu discurso expressa o amor idealizado que busca suprir todas as carências da amante, que a protege, a ampara e cumpre a função masculina pré-determinada socialmente de suprir também os desejos materiais da mulher. Embora acredite ter vivido um ideal de namoro condizente com suas expectativas, a colaboradora relata que seu casamento foi desde o início permeado por constantes brigas, agressão física e psíquica e pelas traições do marido, de modo que ela não faz nenhuma referência à relação afetiva e sexual no casamento antes de Paulo, seu marido, lhe ser infiel. Porém, ela relata sobre a relação que se tramou entre sua primeira gravidez e a infidelidade do marido.

Assim como o marido de Bárbara, Paulo também viajava muito a trabalho, desde o início do casamento, e ao iniciar sua descrição acerca das vivências no casamento, ela relata que supunha que o marido mantinha relações sexuais fora do casamento porque encontrava preservativos em suas bagagens, que não eram usados nas relações sexuais com ela: “na época a gente não usava preservativo porque a AIDS não era nem falada, né? e também não tinha tanto aquela preocupação de doenças venéreas como tem hoje, pelo menos 'prá um casal que só tem um parceiro, uma parceira, e eu tive um parceiro só”.

Embora desconfie que Paulo lhe fosse infiel, já que "usavam preservativos” e, em seu modo de compreender essa atitude, condizia com quem mantém relações sexuais "fora de casa”, Stela resolve indagar do marido sobre a possibilidade de ele the ter sido infiel somente quando estava grávida de sua primeira filha, há vinte e sete anos atrás e ele confirma a sua indagação.

Embora cada indivíduo possua uma identidade única, os atributos intrapsíquicos individuais são atrelados a uma construção sócio-cultural ou, em menor instância, a uma dimensão familiar que possui uma estrutura psíquica inconsciente. Por isto, os membros de uma determinada família possuem características diferentes, porém que se manifestam também em comportamentos comuns. 
Retomando Berenstein (1988), mesmo que os membros de uma família mudem, ela pode ainda se manter idêntica porque há uma relação de identidade com a família do passado que a acompanha quando ainda não tinham filhos ou quando eram pequenos, depois quando estes são adolescentes ou jovens e ainda, quando são pais adultos.

Nessa perspectiva, a identidade familiar é mantida graças à existência do inconsciente grupal que, assim como o inconsciente individual, tem regras de funcionamento específico.

O inconsciente foi inicialmente definido na teoria freudiana, como um conjunto de conteúdos reprimidos, isto é, representações reguladas pelo processo primário e carregadas com energia pulsional, suscetíveis de se converterem em atos, o que faz com que ele assuma uma característica dinâmica.

Essa ótica considera que a família tem com freqüência, funcionamentos cuja significação escapa da consciência dos membros do grupo, embora cumpra a função de regular e conceder sentido às relações entre eles. A consciência de cada um dos indivíduos tem pontos de percepção comuns, pelos quais cada grupo aprende a perceber alguns aspectos e deixam de perceber outros quando são indícios que se referem a um sistema inconsciente no qual se mantém ligados como integrantes de uma estrutura.

Desse modo, o inconsciente familiar é a ocultação de uma estrutura sincrônica que se constitui por fragmentos de estruturas significantes compartilhadas, sendo determinado pela história da família. É, pois, pelo processo de transmissão psíquica que os conteúdos interfantasmáticos são compartilhados entre os membros da família (Eiguer, 1985).

No momento em que Stela indagou de Antônio sobre a sua infidelidade, ela relata ter dito a ele: "Pôxa, bem, ah::: quê que ela [a amante] tinha que eu não tinha? Eu tenho cabelo ah::: castanho claro e ela loiro? Só por causa do loiro...? Ah, eu vou pintar o meu 
também”, e ele lhe ter respondido: “Como você sabe que ela tem cabelo loiro?”. Percebemos com esse discurso que a colaboradora “sabia de antemão”, tinha conhecimento das traições de Antônio, mesmo que ele não tenha veiculado esse conteúdo verbalmente.

Prosseguindo em sua descrição, a colaboradora revela a reação que teve quando Antonio confirmou-lhe que era infiel, como abordaremos a seguir.

aí eu me acomodei, 'tava grávida, eu só pensava no bebê, eu não queria passar nervoso por causa do bebê, era tão esperada que eu não queria que a criança passasse o processo de quando eu 'tava no útero da minha mãe passei. Então, eu quis ser diferente com ela, com o meu bebê.

Continuando em seu relato a colaboradora diz: "Então ah... através disso [da entrada do bebê na relação] eu esqueci, quer dizer esqueci parcialmente [infidelidade], esqueci não, me acomodei na situação”.

Segundo a perspectiva psicanalítica, compreendemos que esse discurso explicita a utilização do “mecanismo de defesa” chamado “negação”.

E ficamos assim: fiquei uns dois meses sem dar beijinho de "selinho", sabe? Ah, sem relação ... [relação sexual], eu inventava mil e uma desculpas: eu falava ah::: hoje eu fui fazer o pré-natal e que o médico falou assim assim .... então, eu inventava mil e uma ... que o médico, né? 'prá não ter que ficar com ele pra não ter relações com ele ... porque aí eu já tava, né? não é mais amor não é mais ... eu já não sentia mais, como eu não sinto ... e toda vez que ele chegava ele vinha com “coisas” [se refere aos preservativos] dentro da mala e era discussão.

Os relatos acima demonstram que Stela tendencia, tal como a primeira colaboradora, Isolda, a renunciar a vivência da sexualidade no casamento no período de gravidez, encerrando-se num enlace de amor com o bebê e nos revela sobre a rejeição sofrida pelos seus pais quando ela ainda era um “bebezinho” na barriga de sua mãe.

eu não queria que acontecesse com o meu bebê o que aconteceu comigo [se refere a rejeição parental] então, eu namorava muito a minha barriga, eu conversava muito, eu falava assim: “apesar de saber filhinha que você é uma 
menina, meu coração de mãe sempre sentiu, né? você é uma menininha, você vai... mamãe vai por 'chiquinha' em você”, aquelas coisas de mãe mesmo ficar empetecando a menina, né? o menino já é um tênis, um shortinho e uma camiseta, acabou. Agora menina não, né?

Embora Stela tenha manifestado alegria com a gestação de uma menina, podemos afirmar que seu relato explicita a transmissão de certos sentimentos e valores da vida psíquica familiar que se referem ao medo de que o sentimento de rejeição vivido por ela pudesse se repetir na vivência de sua filha (Eiguer, 1998).

Como já dissemos, desde o início do casamento, Paulo era infiel a Stela. Nove anos depois do nascimento da primeira filha do casal, por sugestão de uma amiga, a colaboradora decide adotar uma criança: “quem sabe se você pegasse aquele nenê ele não melhora? Deve ser falta de um filho homem, né? Hoje 'tá fazendo 18 anos...” [que adotaram o filho].

Esse relato demonstra que o desejo de ter um filho do sexo masculino assumiu um importante significado para Stela, uma tentativa de "suprir uma falta" e levar o marido a não mais trair a esposa.

Entretanto, mesmo após a adoção do segundo filho, Paulo continua sendo infiel a Stela. Adiante, a colaboradora nos conta que quando seu filho adotivo estava com três anos e meio de idade, ela engravidara novamente: "eu não sei um descuido, foi um descuido muito grande, foi uma coisa muito grande, eu fiquei grávida... do segundo [tossiu] aí esse meu filho veio" e com a chegada do segundo filho biológico, Stela novamente atribui a sua chegada uma possibilidade de causar uma transformação na relação amorosa, como demonstra o relato abaixo quando nos desvela os seus pensamentos:

\footnotetext{
“ele vai pegar o menino, ele vai sair, ele vai ver que não tem mais condições de beber, ele não vai mais me trair, vai acontecer um milagre com a vinda desse meu filho” pensei comigo. Foi pura ilusão. Aí eu fui me acomodando porque as pessoas já não queriam mais saber de mim, saber do meu problema, meus parentes ah::: "você não quis casar? casou?, te vira!"
} 
Ao relatar suas vivências, a colaboradora nos conta que seu pai obrigara a mãe a executar um aborto quando a esperava em seu ventre. Ela diz que a família "não tinha herança 'prá deixar 'prá filhos nenhum e, então, ele levou ela na farmácia, na época, e ela tomou varias injeções 'prá abortar”, o que se justificava pelos precários recursos financeiros de que a família dispunha. Relata que a mãe estava grávida de filhos gêmeos e que a tentativa de aborto realizado pelo casal, não teve êxito. As crianças nasceram, mas logo depois do nascimento, o outro bebê, que era um menino, faleceu.

Ela diz em sua descrição: "por que eu não morri e deixei o menininho vivo? Então, por que tinha quer ser eu que vivi e não o menininho?” e percebemos que, Stela indaga sobre as razões de sua própria existência, melancolicamente.

A partir da vivência citada acima, compreendemos que o desejo de contemplar Paulo com um filho do sexo masculino assumiu para Stela um duplo sentido: mais que satisfazer o ego paterno e levá-lo a supressão de um comportamento infiel, o menino tende a assumir para a realidade psíquica a gratificação da figura paterna que tanto desejou "um filho homem”, o que se explica justamente pelo processo de transmissão psíquica entre gerações.

Porém, Paulo não realizou as expectativas de Stela de que não iria mais lhe ser infiel e assim, a colaboradora se frustra e reclama da situação, de que ninguém lhe dá atenção, como pudemos perceber em seus relatos.

Em seguida, a colaboradora fala sobre os sentimentos de amor e dor advindos das vivências conjugais, tramadas não somente pela infidelidade amorosa, mas também pelas repetitivas brigas e discussões e o modo pelo qual o trabalho de luto acontece nesse trajeto.

Ao relatar sobre os sentimentos que teve quando Paulo afirmou lhe ser infiel, Stela diz: 
eu comecei a sentir ah::: ... que eu estava perdendo a auto-estima, minha ... eu queria, eu queria assim, ah::: que os outros se apiedassem de mim... sabe? pedi socorro 'prá minha mãe, falei: “mãe, deixa eu ficar com você, assim que eu tiver o bebê ela fica com você e eu vou trabalhar. Pedi socorro para minhas irmãs, a única que me amava não tinha condições de ficar comigo, né? Então, foi onde que eu fiquei em casa, eu cheguei a falar de separar dele.

Compreendemos com esse relato que Stela, diferentemente das outras duas colaboradoras apresentadas, que permaneceram silenciosas quanto à traição dos maridos, compartilha as suas aflições com as pessoas ao seu redor. Percebemos também que a colaboradora se vitima, busca no outro o repouso e a culpa para suas angústias e também manifesta o desejo de se separar do marido.

Prosseguindo em sua descrição ela nos relata que embora Paulo não pretenda se divorciar, ela possui uma prova médica capaz de endossar o seu pedido de separação: a existência de uma doença sexualmente transmissível contraída dele.

Agora ele me passou uma HPV, agora eu tenho [uma prova], mas mesmo assim ... agora eu pedi mesmo [pedido de separação], não tem mais condição, não quero mais, acabô, eu joguei 29 anos de casamento, eu joguei... 'você jogou, eu porque permiti, você porque fez, nós dois jogamos 29 anos de casamento no lixo,".

Stela nos revela sobre o trágico drama de uma doença, que é comumente chamada de HPV, causada pelo papilomavírus humano e que tem como conseqüência uma série de sintomas que serão apresentados no decorrer da descrição da colaboradora.

eu converso com ele, ele só sabe gritar e xingar, ele responde: “só se eu fiz com a mulher do teu médico 'prá ter passado 'prá você" [se refere a transmissão da HPV), eu falei: "mas você foi no urologista também...” porque meu médico, assim que viu ele falou: "olha ele tem que ir no urologista fazer exame”, né?, o urologista fez exame nele, deu... ele comprou remédio, tudo que era... 'prá ele fazer tratamento em casa mesmo. 
Como podemos perceber pela descrição de Stela, embora Paulo também tenha contraído a doença, ele não admite o fato de ter contaminado sua esposa.

Continuando, Stela diz:

\begin{abstract}
agora no meu caso, eu não posso fazer tratamento em casa, eu tenho que ir duas vezes por semana no meu médico, ele começou com ácido, não deu certo, ele cauterizou todas por fora [se refere aos sintomas da doença que se manifestam em verrugas] com a anestesia local, nas paredes está cheia [se refere as paredes da vagina]
\end{abstract}

Com os últimos relatos percebemos que a doença se manifesta de forma diferente no homem e na mulher, seja em relação ao tratamento, seja em relação ao prognóstico. Enquanto o homem pode "realizar o tratamento em casa", a mulher acometida pelo HPV deve se submeter a um tratamento mais complexo, árduo e mais duradouro que ele, isto porque homens e mulheres são anatomicamente diferentes.

Continuando a colaboradora diz: “a dele foi mais fácil de ser curada porque ah::: não é uma cosia abafada como a nossa é... úmida, né? Do homem é sempre mais fácil e a dele já foi curada...” e revela o quanto as repercussões psíquicas que a doença pode causar podem também ser diferentes para homens e para mulheres. No caso de Stela, a doença “é difícil de sarar”, pois além das complicações físicas que acompanham o quadro, o HPV se liga à traição conjugal.

Relata ainda que após contrair o HPV, ela realizara exames de outras DSTs, tais como, hepatite e HIV e nos diz que: “graças ao bom Deus, não deu nada”. Entretanto, prossegue dizendo que:

infelizmente eu 'tô assim: faz dois meses que eu estou na base do ácido ... e da cauterização ... e da anestesia local, que é uma parte muito sensível [se refere ao órgão genital], dói e não 'tô conseguindo combater esta doença devido ao meu sistema imunológico, acaba afetando. 
Seu discurso mostra o sofrimento corporal decorrente de uma doença física, bem como a relação deste com o seu estado emocional.

De acordo com Moreira (2002), os vínculos que unem o stress e a inquietação ao sistema imunológico, tais como o anúncio de uma infecção, um episódio depressivo ou a morte de uma pessoa querida, podem provocar além da depressão, uma queda da taxa de linfócitos t4, isto é, uma diminuição da imunocompetência do sistema imunológico.

Sabemos que, no caso de Stela, a dor física vem acompanhada por um complexo conjunto de desilusões matrimoniais, que tem repercussões em sua saúde psíquica.

Stela nos relata ainda que o ginecologista lhe alertou de que é possível que ela tenha que prosseguir com o tratamento dessa doença ainda por um ano, como vemos no relato abaixo:

Ele 'tava até pensando mesmo em mandar 'pro hospital e fazer tudo a base da raqui, mas ele disse: "Stela, eu tenho medo de fazer isso ...”. Não é fácil, dois meses não está sendo fácil de ficar assim... "não”, ele falou: "um ano ..., se eu acabar com essas agora e elas não voltarem dentro de um ano, não volta mais”, aí, eu vou ficar na expectativa...

E prosseguindo, ela desabafa: “agora diz 'prá mim: 'qual mulher que agüenta ficar um ano indo duas vezes por semana num ginecologista?' ”.

Continuando, ela nos relata sobre os tratamentos ginecológicos:

porque ele fez tudo externo, não ficou nada externo [se refere ao exterior da vagina], eu voltei a semana passada brotando novamente em outros lugares, então, como nas paredes não tem como ele dar anestesia e cauterizar, ele deu o gel com aplicador que é a base de ácido para ser colocado um dia sim e um dia não, nesse intervalo, dessa pomada, eu coloco uma que não deixa corroer a pele, né? não deixa infeccionar a pele [...] "e nesse um ano você vai ter que vir aqui fazer a Via Sacra de vir aqui toda semana duas vezes por semana, só que tem uma coisa, eu vou chamar o seu marido porque eu quero conversar com ele”, aí meu marido, ele jura de pé junto que não fez nada, que não fez nada. 
Uma relação entre culpa, dor e abandono parece permear a descrição de Stela, pois a representação social que a "Via Sacra” assume em nossa sociedade se refere ao ritual pelo qual a pessoa deve passar para pagar um pecado cometido. Eis que "pelo pecado do sexo”, contraiu o HPV e em relação a sua doença, o marido lhe é indiferente. Percebemos que o eu sofre corporalmente com os sintomas advindos da doença e, psiquicamente, com o abandono do marido que não divide com ela as responsabilidades que envolveram a transmissão da doença e nem o seu tratamento.

Stela nos relatou que no início de seu casamento, o casal não usava preservativos, já que esse hábito não era comum na década de 70. Entretanto, percebemos que em vivências futuras, o casal também não fizera o uso de preservativo já que tanto Paulo quanto Stela foram infectados pelo HPV.

Compreendemos desse modo, que o não uso de preservativos vai além da viabilização de um processo educativo que veicula informações atualmente sobre a necessidade do uso do preservativo, bem como sobre a AIDS e outras doenças sexualmente transmissíveis, pois em contrapartida, muitas pesquisas mostram que o não uso de preservativos, seja entre os casais mais novos ou entre os mais velhos, ainda é um fenômeno pertinente que se fundamenta na crença no ideal do amor romântico e das diferenças de gêneros. Como exemplo disto, podemos retomar a pesquisa realizada por Zampieri (2004) que explicita o comportamento de mulheres que, por abominarem a desconfiança em relação à fidelidade do marido, vai contra a fundamentação cristã de fidelidade conjugal, não usavam preservativos nas relações sexuais. Nossa herança sóciocultural ainda nos revela que “o amor não usa camisinha” posto que ele é "único” e “eterno”, não devendo, portanto, se precaver.

Ao relatar sobre as dores corporais provenientes da doença contraída, a colaboradora diz: 
ontém eu estava... eu estava ontem e estou hoje queimando em brasa [ênfase] [...] eu 'tô até impossibilitada de dirigir, eu vim aqui mesmo porque eu tinha marcado com você, né?, com a Dra Elisa [psicoterapeuta], eu ia falar: "eu não vou, porque 'tá queimando, 'tá queimando como um fogo. Então, eu chegar em casa ... porque eu vou ligar 'prá ele [para o médico], porque ele falou: "Stela, se queimar muito você me liga”.

Esse relato manifesta o quanto a dor corporal comociona o $e u$, $e$ vai além disto, pois se configura na expressão de como o grande significado do ato de encontrar-nos e conceder-nos a sua descrição é importante para Stela.

Compreendemos “que o interesse em nos relatar suas vivências retrata justamente a grande importância dirigida as suas feridas”, sejam elas psíquicas ou físicas.

Segundo a perspectiva de Nasio (1997), quando a dor, chamada fenômeno-limite, situa-se além do corpo, no espaço imaterial de um poderoso laço de amor, ela é a dor psíquica. Porém, quando uma lesão está localizada no corpo acarreta uma dor chamada dor física ou corporal.

Mas essa dor é vivida erroneamente no corpo, pois na verdade ela se localiza no cérebro, tanto quanto a sensação dolorosa, quanto a emoção dolorosa. Nessa ótica, a dor de amputar uma parte do corpo é a mesma dor interior de perder um ser querido, pois gostamos do nosso corpo como o outro mais amado. Assim como a dor psíquica, a dor corporal também exige um verdadeiro trabalho de luto, que visa ensinar o amor ao novo corpo desprovido de alguma parte que era dele.

A lesão que provoca a dor corporal está situada no nível da amputação, enquanto a lesão causadora da dor psíquica, presente quando perdemos uma parte de nosso corpo, situa-se em três planos diferentes entre si e que são semelhantes aos planos que definem a perda do ser amado. Esses planos são: (1) o da sensibilidade, pois a parte amputada é uma parte do meu todo visível; (2) o do imaginário, pois a imagem da ausência da parte 
amputada muda a imagem do meu corpo; (3) o do simbólico, pois a ordem psíquica perde uma das maiores referências que é a integridade do corpo.

A dor corporal é ainda o resultado da irrupção violenta de grandes quantidades de energia que atingem no nível do inconsciente, o centro do $e u$, isto é, os neurônios da lembrança. Ela resulta, portanto, num grave transtorno do eu, bem como na paralisia do princípio de prazer, que é o guardião do nosso equilíbrio psíquico.

Assim, a dor corporal é comparável à pulsão e exprime um além do princípio de prazer que pode comocionar o eu, embora não o destrua. Mas, difere-se da pulsão por finalidades diferentes dela: enquanto a pulsão procura o prazer, a dor é um sinal de alarme para fazer cessar o desprazer, o mal.

A dor corporal é ainda um excesso de amor pelo órgão lesado, em detrimento dos outros objetos de amor e por isto, ao reagir a ela, o eu reúne todas as forças disponíveis e mesmo correndo o risco de enfraquecer-se, ele as concentra em um único ponto: o do ferimento, isto é, no ponto da representação psíquica do ferimento.

Quando isto acontece, a dor se torna um afeto que resulta do superinvestimento da representação do órgão lesado e, simultaneamente, do desinvestimento do mundo exterior, tal como percebemos na descrição de Isolda acerca de suas feridas corporais. A imagem corporal da dor física apresenta-se tão superinvestida pela colaboradora que a manifestação de satisfação em relatar-nos suas vivências expressa justamente esse superinvestimento da dor.

Falar intermitentemente de sua dor significa, pois, expressar esse processo de super investimento em que o eu vive somente a dor, isolando-se e desinteressando-se por qualquer atributo do mundo exterior, como é possível percebermos no relato abaixo, quando Stela se refere ao comportamento do marido em relação a ela: "Sabe quando que ele me nota? só a hora de tratar dos passarinhos, eu trato de vários passarinhos... primeiro 
eu gostava, era um prazer tratar deles, agora não é mais, não é mais, agora se eu pudesse ficar enterrada na cama ficaria”.

Retomando Forghieri (2001), existem diferentes maneiras do ser humano existir no mundo, que possui se apresenta sob vários aspectos, isto é, no conjunto de relações significativas no qual existimos. Nessa ótica, o "mundo próprio" se refere àquele que estabelecemos conosco mesmos, um ser-si-mesmo, na consciência de nós mesmos e no autoconhecimento; o "mundo humano" se refere aquele que diz respeito aos nossos encontros e convivências com nossos seus semelhantes e; o "mundo circundante” abrange os condicionamentos aos quais estamos parcialmente sujeitos, pois vivemos concretamente num ambiente e sofremos limitações decorrentes de nossa corporeidade, cabendo a nós mesmos adaptarmo-nos a elas, já que possuímos a capacidade de transcendê-las.

Percebemos que não conseguindo superar a situação atual, Stela busca ensimesmarse, isolando-se daqueles ao seu redor e encerrando-se num fechamento em sua própria dor. Mas compreendemos também que a manifestação do desejo de morte, latente nos relatos da colaboradora, é a expressão de sua melancolia.

O termo melancolia fora utilizado pela Filosofia, pela Medicina, pela Psiquiatria e até mesmo pelos poetas, ocupando um lugar importante na teoria freudiana. Segundo Roudinesco e Plon (1998), o termo se caracteriza por uma tristeza profunda, um estado depressivo seguido de manifestações de medo e desânimo que podem adquirir um aspecto de delírio ou conduzir o indivíduo ao suicídio. Sigmund Freud explicou o termo melancolia em 1917, no texto "Luto e melancolia”, referindo-se a uma "ferida aberta” capaz de atrair para si os investimentos provenientes de todas as direções ao mesmo tempo em que esvazia o eu até este ficar empobrecido. 
Na visão de Moreira (2002), o que seria capaz de conduzir um indivíduo à melancolia é justamente a quebra súbita do equilíbrio narcísico, quando esta lhe impõe uma perda narcísica irreparável.

Essa autora analisa a representação que os pacientes com AIDS têm de si mesmos, ao serem portadores de um vírus tão letal como o HIV. Percebemos que as vivências relatadas por Stela encontram ressonâncias com o trabalho de Moreira (2002), pois acometida por uma HPV, Stela encontra dificuldades em construir novos ideais de ego e atribuir novos significados a sua existência, em representar a sua própria identidade e manifesta uma imensurável redução da auto-estima, senão ensimesmando-se em sua dor.

Ao prosseguir em sua descrição, ela diz: "eu faço acumputura, é dentista, psiquiatra, psicóloga eu saio só ‘prá isso, minha vida agora é só isso... há nove anos já é só isso... eu tive muitas mortes na família, desses nove anos 'prá cá eu entrei numa depressão muito brava...” relatando que necessita de ajuda especializada.

Nasio (1997, p.177) afirma que quando sentimos dor "representamos o corpo e, ao fazer isso, constituímos o nosso eu. Portanto, o eu nasce de todas as percepções sensoriais e das representações que se formam no psiquismo”. Nesse contexto, toda vivência quotidiana pode ser compreendida como um complexo de afetações no qual "psique” e “soma” constituem uma estrutura comum, não havendo, portanto, manifestações do existir que não sejam corporais.

Ser "sadio" consiste para a fenomenologia em se abrir às próprias possibilidades e em aceitar e enfrentar os paradoxos e as restrições de nossa existência. “A saúde existencial está profundamente relacionada ao modo como conseguimos estabelecer articulações eficientes entre a amplitude e as restrições de nosso existir” (FORGHIERI, 2001, p.53), enquanto que as limitações e os conflitos que não são reconhecidos e enfrentados por nós podem tornar-se exageradamente ampliados e dominantes, resultando 
em um processo de adoecimento. Consideramos que esse modo de compreender o adoecimento explicitado pela autora nos é significativo na medida em que percebemos que a colaboradora expressa dificuldades em lidar e modificar seus rumos existenciais, apresentando grandes limitações existenciais e manifestando sensações de ter adoecido, como podemos perceber no discurso abaixo:

\footnotetext{
"No passado, eu podia dizer 'prá você que você era bela e burra. Hoje não, hoje você é burra mesmo, burra e doente" - que realmente eu preciso de psiquiatra, psicólogo, ginecologista, tudo - "só que nem um, nem outro tem a capacidade de ver que você é louca e te dar um 'chute’”- aí eu disse 'prá ele: “ótimo, eu posso me internar, só eu querer eu posso me interna no SC [hospital psiquiátrico]”"você não pode"- “eu peço ajuda 'prá médico, eu vou lá, falo que eu 'tô 'louquinha', eu seu que de lá eu não saio mais mesmo”- e eu afirmando - "não saio, mas saio a hora que eu quiser... oba, eu vou chorar só ou eu vou sorrir só, sei lá...”.
}

Embora a percepção de ter adoecido e a manifestação do desejo de morte estejam presentes em suas falas, percebemos que a batalha entre vida e morte é uma constante em sua existência cotidiana. Embora a "pulsão de morte” esteja fortemente evidente em seu discurso, Stela clama pela ajuda de profissionais especializados a fim de que a auxiliem em suas limitações, libertem-na de suas angústias nessa trajetória existencial.

A partir das descrições da colaboradora, compreendemos que ela se sente deprimida e abandonada e em desequilíbrio, reage melancolicamente.

Na concepção freudiana, a melancolia pode assumir várias formas clínicas, desde que determinadas por um conflito psíquico básico: a perda de um objeto amoroso.

Segundo a perspectiva de Moreira (2002), há uma tendência generalizada em se utilizar o termo “depressão" como sinônimo e em substituição ao "melancolia”, devido ao fato do termo “depressão" ter uma origem muito recente e a sua utilização indiscriminada pela Psiquiatria. 
Essa autora considera que no caso do HIV, muitos sintomas somáticos apresentados pelos pacientes são muito semelhantes aos sintomas de uma pessoa com depressão sendo a considerável redução da auto-estima, sentimento recorrente nas descrições de Stela, um diagnóstico diferencial entre “melancolia” e “depressão”.

A possibilidade da morte nas doenças venéreas tem, sem dúvida, uma dimensão relativa e expressa uma relação entre sexo e morte; porém o sentimento de perda seja em relação ao bem estar físico e psíquico, seja em relação ao sentimento de abandono do marido, parece constituir-se no desencadeamento da melancolia de Stela.

Ao fazer em sua descrição referências às ressonâncias da infidelidade na vida dos filhos, Stela se refere apenas a um deles, dizendo:

\footnotetext{
eu tenho uma filha que 'tá com vinte e sete anos, a minha filha mais velha, ela é uma menina super bacana, inteligentíssima, escreve muito bem, trabalha, tudo, mas ela é uma verdadeira criança, é uma criança grande... devido o que ela viu entre nós dois, porque ela prefere levar o lado brincando, ela enfrenta muito ele, ela é solteira, ela mora sozinha e ela fala ‘prá mim: - "vem morar comigo, mãe”-, até meus filhos me chamam de mamãe, mamãe, papai, então ela fala: "vem morar comigo, mãe.
}

Compreendemos com esse relato que mais uma vez, Stela culpa o outro, o marido, dizendo sobre no quê seu mau comportamento de brigas, agressões, controles e traições resultou para a vida da filha, na imaturidade desta. Por outro lado, na figura da filha, a colaboradora encontra um ponto de apoio, alguém que compartilha com ela essa trágica história familiar, na qual além dos elementos citados acima, a passividade feminina também é patente. Assim, na próxima dimensão fenomenal, ciúme e violência: a tragédia amorosa, damos prosseguimento à apresentação desse drama.

Stela relata "que sempre desejou trabalhar "fora de casa”", mas que "prá fora ele não deixou, ele me ameaçava, foram muitos anos de ameaça”.

Prosseguindo em sua descrição, ela diz: 
agora em novembro do ano passado, não, em setembro, eu vi que ele 'tava muito carinhoso, me levou para ver muitos shows, aconteceu um fato de eu ficar com os cantores no camarim, tirar fotografia, ser filmada, sabe? e num desses show, ele deu o telefone dele 'prá uma mulher”.

Esse discurso revela que, embora tenha se sentido valorizada pelo marido que a levou "para sair" e que lhe proporcionou momentos de satisfação junto aos cantores do show, ela sentiu-se, contraditoriamente, desvalorizada e humilhada quando o marido a desrespeita enquanto esposa, interessando-se por outra mulher em sua companhia.

Stela revela que as agressões físicas e morais sempre foram constantes em seu casamento e relata uma situação na qual a filha do casal estava com cinco anos de idade e Paulo tentou lhe matar, como segue nos relatos abaixo:

ele bebeu muito e tentou me matar ... eu na época eu vendia lingerie, vendia produtos do PIPI [nome de empresa], sabe? pra ajudar na casa porque trabalhar pra fora ele não deixava, ela falava: “mulher trabalha pra fora, mulher que estuda pra fora, não é boa coisa, ou vai dar pró patrão ou vai dar pro professor ...” não são essas as minhas palavras, são as dele então eu trabalhava dentro de casa vendia [...] por telefone [...] ele falou assim pra mim: "você tem mil cruzeiros pra me dar? que eu vou no bingo? vai ter no serviço e eu vou levar minha filha”.

Embora o ideal patriarcal de divisão entre os papéis sociais entre os gêneros se fazer presente no relato acima sua constituição não é híbrida, se alia a um novo padrão moral de comportamento que visa a contribuição financeira da mulher no provimento do lar.

A assimilação dos padrões culturais vigentes de uma determinada época entra em coesão com os padrões morais e culturais dos ancestrais, que são internalizados por nós, mediante à transmissão intrapsíquica (Eiguer,1998).

Por essa razão, há uma re-atualização de velhos padrões de pensamento e comportamento, que colidem com novos padrões e deixam o eu em conflito entre aceitar 
ou não mudanças. Assim, Paulo não “autoriza” que a esposa trabalhe fora de casa, porém, empresta dela “o dinheiro ganhado numa transação comercial”, que não foi feita por ele.

Após pai e filha passarem o dia fora, Stela diz que ao chegarem da festa do trabalho, "ele [Paulo] veio tri-bêbado, muito, muito, muito, não enxergava nada, minha filha veio suja de terra, eu já ‘tava com a janta pronta só faltava fritar os bifes”.

Stela nos revela uma dramática violência doméstica, como segue abaixo:

\begin{abstract}
Então eu disse: "filha, vai jantando o arroz e feijão e a mamãe vai fritando o bife que depois eu entrego picadinho no seu prato, aí ela falou assim 'prá mim: "me dá farinha de milho?”. Eu fui até o armário pegar a farinha de milho e pus no prato dela, foi aonde ele avançou com uma faca de cabo grande com a lâmina muito grande, essas facas de açougue, de açougue... ele disse 'prá mim: "você vai dar farinha 'prá minha filha comer e eu vou te dar formiga 'prá você comer porque é hoje que você vai 'prá debaixo da terra”, e veio em cima com a faca só que eu não me lembro se fui eu que desviei da faca ou se algo me empurro, sabe? alguma coisa aconteceu eu sei que a faca não pegou se ela pegava, pegava direto no coração.
\end{abstract}

Ao relatar a tragédia, Stela diz que Paulo furou com a faca uma panela que estava no fogão e que a vizinhança, ao ouvir seus "berros” pedindo por ajuda, tirou-as da casa “a minha irmã veio, foi tentar falar com ele, quase matou ela também, ele cortou todos os meus sofás eu tinha um sofá grande com duas poltronas, na época era o que usava e de napa, ele cortou e ele mesmo chamou a polícia”.

A vivência exposta pela colaboradora, que se refere à de um marido alcoolizado que agride a esposa, é palco de uma violência doméstica entre gêneros, composta pela agressão física e psíquica.

Continuando em sua descrição, a colaboradora afirma que depois de chamar a polícia, Paulo escondeu a faca utilizada e relatou à autoridade a sua versão dos fatos: “ele me xingava de tudo quanto era nome, ele falou que eu tive uma briga, que eu não queria dar comida para a filha dele, inventou uma porção de coisas”. 
A violência física se manifesta pela utilização de uma arma, uma faca, mesmo não tendo o agressor atingido a vítima corporalmente.

A violência psicológica vivenciada por Stela se implica justamente no quadro de características apontados por Araújo, Martins e Santos (2004), referentes à agressão psicológica: agressões verbais, xingamentos, humilhações, ameaças, desqualificação, calúnia, acusações, críticas infundadas e abuso de poder e autoridade, constrangimentos entre outros.

Esse cenário parece expressar uma forma particular de violência global mediatizada pela ordem patriarcal que concede ao ser masculino o poder de dominar e controlar suas mulheres podendo até utilizar de violência.

A colaboradora afirma que após essa ocorrência ela pedira a Paulo a separação, mas que ele lhe “ameaçara” tirar os planos de saúde e não lhe pagaria pensão.

\footnotetext{
ele me ameaçou de tudo quanto foi forma, pediu perdão, aí ele fez um monte de gente ser testemunha que ele não ia fazer mais nada, passou..., nos ficamos 6 meses juntos, mas assim: eu sempre com receio dele quando ele ia trabalhar eu não sabia como ele ia voltar, como ia ser entendeu? [...] eu levei anos assim... eh::: pedindo socorro, eu pedi socorro 'prá minha própria mãe e minha mãe falou assim: "ah deixa isso 'prá lá, eu agüentei muito mais do meu marido, você pode agüentar também.
}

Percebemos nesse relato que configurações de objetos psíquicos, tais como os afetos, as representações e as fantasias de fato se transferem de um espaço psíquico a outro, de modo que se é veiculado pela figura materna que “a mulher deve ser submissa ao marido”.

Entretanto, Araújo, Martins e Santos (2004), afirmam que embora o homem seja o maior agressor nas situações de violência, nem todos os homens utilizam esse privilegio patriarcal da mesma maneira, assim como nem todas as mulheres se submetem igualmente a essa dominação. Ao relatar sobre uma outra situação de violência, a colaboradora diz: 
a última surra que eu tomei dele foi em 93, mas, por quê? Aí eu também não sei da onde que eu tirei força... eu apanhei, fiquei roxa, mas eu quebrei o braço dele, queimei a minha mão, mas eu queimei o braço dele, eu queimei, queimei com o cigarro e ele teve que ir "pro pronto socorro e eu falei 'pro ortopedista: "pode fazer o B.O. fui eu que quebrei o braço dele”, o ortopedista olhou 'prá mim e falou: “só o braço você quebrou?”, podia ter quebrado tudo!”, porque o ortopedista viu como eu 'tava ... foram os dois 'pro pronto socorro, "pode fazer B.O., fui eu que quebrei o braço dele”, ah::: “não, não vale a pena você só quebrou o braço”

Essa perspectiva considera que a violência de gênero deve englobar atualmente as diferentes formas de violência praticadas no âmbito das relações de gêneros, não somente aquela praticada por homens contra mulheres, mas também a violência praticada por mulheres contra homens e aquela praticada entre pessoas do mesmo sexo.

As novas configurações de gêneros determinam na atualidade uma nova dinâmica na violência de gênero, já que muitas relações afetivas e sexuais não se constituem somente por relações heterossexuais.

Desse modo, percebemos que Stela não se submete passivamente à violência do marido, de modo que denuncia o seu agressor, bem como reage à agressão.

Compreendemos ainda que a vivência de uma conjugalidade repudiada pelas constantes infidelidades e agressões físicas e psíquicas compôs um cenário de restrições existenciais, no qual, mesmo agredindo o parceiro, a falta de compreensão e de correspondência de afetos a fez mergulhar em um universo existencial em que os sentimentos de aflição, perplexidade e abandono são constantes promovendo grandes descontentamentos e insatisfações na vida-a-dois.

Ela revela ainda que o cenário financeiro e as mentiras no casamento se tornam lugar-comum na dinâmica da infidelidade, promovendo grandes desilusões, como podemos perceber no relato abaixo: 
ele me fez uma, duas, três ..., ele me traiu até ah::: com dinheiro, tá?, de emprestar dinheiro prás pessoas e não contar pra mim, sendo que eu que faço ... que pago contas, vou em banco, porque ele nunca teve tempo pra isso. Só que ele tem... ele tem uma renda que eu não sei da onde vem, que essa renda eu não tenho como provar, então, ele emprestava pra alguém e mentia pra mim. A pessoa chegava e falava assim pra mim: “fala pra ele 'brigado, viu? daquele dinheiro... nossa, valeu!”, aí que eu ia saber que ele tinha emprestado dinheiro.

É importante notar que assim como as outras colaboradoras, Isolda e Bárbara, que atribuíram significados à "falta de dinheiro" no casamento ou "o uso dele pelo marido sem o consentimento ou conhecimento da esposa”, relacionados à traição, Stela também se refere à relação estabelecida entre o aspecto financeiro e a infidelidade amorosa. Isto porque o empréstimo que Paulo faz ao amigo é secreto, é um segredo que não compartilha com a esposa.

Apresentaremos uma outra dimensão existencial do fenômeno: a re-significação do relacionamento amoroso: o aprisionamento da dor.

Revelando ainda sobre como se sente no casamento, a colaboradora diz que se percebe como uma “muleta”: “eu já não digo mais, que eu sou o “esteio” da casa como diz o outro, né? Eu sou alicerce, as parede, a “muleta”, tudo pra ele, tudo assim, né? submissa, a tonta, a burra, né?” e manifesta o desejo de separar-se do marido, embora não o faça.

Em sua descrição, a colaboradora relata que sempre quando a filha mais velha convida a mãe para morar com ela, Paulo faz ameaças a elas: “vai, se quer sujar tua cama de sangue vai, leva ela [a mãe]...que quero ver ela morrer” e prossegue seu relato dizendo:

\footnotetext{
Eu quero, o que eu mais quero... eu quero... ou me separa dele ou morrer... não tem mais o porque eu voltar pra casa. O porquê eu, eu não tenho mais... eu era uma pessoa tão limpinha, tão cuidadosa, tão caprichosa, sabe? Cheguei a engraxar as botas dele, dar brilho, sabe? Não tenho mais nada, não tenho mais motivação para estar com ele, não tenho...
}

A partir desse discurso, o caso de Stela nos parece ser o que melhor ilustra o conceito de ressentimento de uma mulher cujo marido lhe foi infiel. 
“O ressentimento traduz a falta como prejuízo cuja responsabilidade é sempre de um outro contra quem ele dirige insistentemente um rosário de queixas e de acusações” (KEHL, 2004, p.33). Como pudemos perceber, Stela atribui aos outros as dificuldades e as alegrias de sua existência. Ela se queixa por ter nascido, por continuar casada, por não ter recebido afeto nem apoio familiar e, por fim, queixa-se por estar "impossibilitada" de se separar do marido que a ameaça de morte caso o faça.

O ressentido é aquele que se apresenta diante do outro como alguém “coberto de razões": "Não é fácil abrir mão de um sofrimento tão justificado: daí decorre o que denominei, de início, o ato de vontade que sustenta o ressentimento. A repetição da queixa é veículo de gozo, como toda repetição, mas trabalha também em defesa da integridade narcísica do eu.” (KEHL, 2004, p.35).

Stela diz: “... eu tenho meu acupunturista, tenho o ginecologista e o psiquiatra, tenho três... os três são doutores [...] eu tenho testemunha [refere-se às infidelidades do marido]”. Esse relato desvela a "repetição” do drama conjugal, composto por constantes infidelidades do marido e constantes agressões mútuas, que se atualiza em cada uma dessas especialidades médicas, mantendo a repetição da queixa e a constante permanência da dor.

Quanto à vivência da sexualidade no casamento, Stela revela que desde que a primeira filha nasceu, período no qual descobriu as infidelidades do marido, a vivência da sexualidade do casal “não era mais amor, já não era mais carinho, já não era mais nada... era como servir um prato de comida para alguém” e relata ainda que, atualmente, “eu vou ao banheiro, ele não permitia [antes], agora eu tranco, eu quero ver ele arrebentar a porta, ele não permitia, agora eu penso comigo: sabe... será que ele pensa que eu vou fazer com chuveirinho ou estou me masturbando com o desodorante ou tô o quê?, que ele está pensando pra não deixar eu fechar a porta?”. Compreendemos que os dois relatos 
atualizam a expressão da exploração patriarcal de dominação masculina e de submissão feminina.

Ao retornamos nesse trabalho à dinâmica do ressentimento, afirmamos que Sigmund Freud não tratou diretamente desse tema, embora tenha estabelecido uma associação entre a melancolia e o luto em dois de seus textos: "Introdução ao narcisismo", de 1914 e "Luto e melancolia, de 1915”. De acordo com Kehl (2004), uma possível semelhança estabelecida entre essas duas manifestações parece existir e residir "na recusa ativa do sujeito em aceitar a perda” Em seus dizeres:

“O ressentido, assim como o melancólico, mantém uma atitude amarga e pouco esperançosa diante da vida, e parece tão preso ao passado quanto aquele impossibilitado de esquecer as supostas causas de sua infelicidade”. (KEHL, 2004, p. 36).

Porém, a diferença mais importante entre elas é, na visão de Kehl (2004), a perda do amor-próprio, característica principal do quadro melancólico e ausente no luto dito normal, o que vem corroborar com a afirmação feita por Moreira (2002) sobre a imensurável perda da auto-estima na melancolia.

Na perspectiva de Kehl (2004, p. 36):

O luto é lento e doloroso processo de desligamento da libido de um objeto perdido. Durante o trabalho de luto as funções do eu ficam empobrecidas em razão do montante de energia (contracatexias) que tal desligamento requer. Mas uma vez terminado o trabalho de desligamento, o eu retoma sua antiga disponibilidade para a vida, sem perder o amorpróprio. O mesmo não acontece na melancolia, na qual o sujeito permanece fortemente ligado ao objeto que o abandonou, e o eu desvaloriza-se como se fosse o culpado do abandono que sofreu. Além disso, a natureza da perda sofrida na melancolia é inconsciente; o sujeito sente que perdeu algo muito importante, mas não sabe o que foi. A natureza do objeto perdido, neste caso, é mais ideal do que no caso do luto, onde o sujeito sofreu uma perda real - o que pode ser mais real do que a morte?

Percebemos pelas descrições de Stela que ao ser indagada quanto aos possíveis redirecionamentos de afetos e atitudes no casamento, a colaboradora desvela não ter 
cumprido o luto. Percebemos também que Stela não consegue nomear “o que perdeu” de modo que, empobrecida pela imensurável baixa auto-estima, manifesta sua melancolia.

Para Kehl (2004, p. 37, grifos do autor):

O interminável trabalho de luto efetuado pelo melancólico empobrece definitivamente o eu que termina por ter razão, diz Freud, em relação às insuficiências de que se acusa. O complexo melancólico é como uma "ferida aberta", que atrai para si grandes montantes de carga de libido do $e u$. "A questão é que na melancolia o sujeito não esta efetivamente tentando superar uma perda: esta reagindo contra ela.”

Embora a impossibilidade do sujeito se desligar do objeto seja uma das condições econômicas do ressentimento, é a forte adesão à ele que representa o melancólico, sugerindo o vínculo que havia sido estabelecido com o objeto fora da natureza narcísica, carregado de fortes sentimentos ambivalentes.

Essa visão considera que o desligamento é impossível na melancolia porque o eu esta identificado com o objeto perdido e odiado.

Enquanto na melancolia a identificação com o objeto parece mais precoce, pois o objeto abrange todo o eu, a forte ambivalência que rege a relação do eu com o objeto desta identificação inconsciente é revelada nos ataques e acusações que dirige contra si mesmo e também indica a precocidade da formação da estrutura melancólica, isto é, a precocidade da perda sofrida.

A ambivalência de tal vínculo agrava, na visão de Kehl (2004), o sofrimento melancólico, pois o ódio do eu contra o objeto amado favorece o masoquismo moral diante do sadismo do supereu.

Dando continuidade a sua descrição, Stela diz:

ele me olha de uma maneira, como quem diz -que eu leio nos olhos dele- "eu era novo, tinha vinte e quatro anos, quando eu me casei com você, fui mulherengo, vou continuar sendo e você vai ficar nas minhas unhas até a hora que Deus te chamar...” 
Esse relato manifesta a incapacidade de Stela de re-direcionar sua trajetória existencial, pois ela acredita que assim como apresenta dificuldades em transcender à experiência imediata, o marido também não apresenta possibilidades de se relacionar no casamento de forma menos restringente de sua liberdade humana.

Desse modo, as auto-acusações do melancólico, ou seja, a culpa, tal como é evidente nos relatos da colaboradora, possuem a tenacidade de uma perfeita solução de compromisso: funcionam ao mesmo tempo como ataque do eu contra o objeto ao qual esta identificado, e como acusação do supereu contra os seus próprios maus sentimentos.

O referencial teórico exposto nos concede, pois, artifícios para considerar que Stela não manifesta um quadro de ressentimento, mas de fato um quadro melancólico, no qual não consegue cumprir o processo de luto, nem direcionar o seu universo existencial, mantendo-se “paralisada” numa vivência aprisionadora.

Passaremos agora, à compreensão e interpretação da descrição da temporalidade de Flor de Liz frente ao fenômeno da infidelidade e da re-significação do relacionamento amoroso. 


\section{FLOR DE LIZ}

Entrevista realizada em 15 de Abril de 2004.

Flor de Liz tem 45 anos e seu parceiro 47, foi casada por 24 anos no civil e por 06 no religioso, casou-se aos 21 e seu marido aos 23 anos. O casal esteve separado por 02 anos, após Miguel, seu marido lhe ter sido infiel e lhe ter “abandonado”. Há 06 meses se reconciliaram, embora estejam morando em casas separadas. A religião do casal é católica e o nível econômico da família corresponde à classe B1. Eles têm uma filha de 25 anos e um filho de 21. Flor de Liz possui ensino superior completo e Miguel ensino médio completo. Ela trabalha na área da educação e ele na área de finanças. Flor de Liz relata que o marido nega a infidelidade amorosa, e que sofreu muitas dificuldades com ela e com a separação do casal, sentindo-se muito sozinha e impotente frente às situações do dia-a-dia e manifestando sentimentos "fóbicos". Contudo, buscando se reconciliar com o marido seis meses antes da data da entrevista, ela ressalta a importância do amor no casamento e da reconstrução da relação conjugal.

Em sua descrição, Flor de Liz relata suas vivências na adolescência e na juventude, revelando como seus pais compreendiam as questões relacionadas ao afeto, à sexualidade e às relações entre gêneros e como transmitiam aos filhos, os valores referentes a essas questões.

eu sou/sofro com a educação, porque minha mãe foi uma pessoa muito liberal, meus pais, todos dois, 'prá idade deles, 'prá época deles, eu vivi minha adolescência... meus pais eram muito avançados 'prá aquela época, não era hippy, viu?, mas eles tinham uma cabeça muito aberta, era muito diferente da época, era muito mais avançada, era muito mais 'prá frente. Meus pais viviam trinta anos à frente de 60, de 70, quando 'tava no período de 70, meu pai tinha uma cabeça do 
ano 2000. Era completamente diferente e minha mãe também, então, meu pai era muito aberto em relação a sexo, a gente conversava tudo, meu pai era médico e ele conversava tudo e ele explicava tudo de seio, de menstruação, de hormônio, de tudo.

É importante notarmos que apesar de Flor de Liz e Bárbara terem uma diferença cronológica de idade de apenas dez anos, o relato de Flor de Liz acerca de sua relação com os pais na adolescência se difere significativamente das vivências que foram relatadas por Bárbara, no que diz respeito ao esclarecimento sobre questões que envolvem a sexualidade, bem como em relação à liberdade para tratar dessas questões.

Enquanto Bárbara se casara aos 20 anos de idade por volta de 1964, Flor de Liz se casara aos 21 por volta de 1974. Embora haja uma grande preocupação com uma possível construção de formas de vida mais gratificantes para o mundo contemporâneo, preocupação inclusive com o fato dos direitos femininos, iniciada nos últimos 40 anos do século XX, algumas modificações na intimidade passaram a ser significativas somente a partir da década de 70, mostrando uma tendência à revolução da subjetividade humana, especialmente para as mulheres.

Segundo Torres (2000), as concepções sobre o lugar da mulher na família, definidas fundamentalmente na função materna, a sua missão central, incompatível com a idéia de uma mulher autônoma, "senhora” de seu destino e de suas opções, capaz de se sustentar ou de partilhar com o parceiro as funções de provedor da família, constituíram obstáculos à idéia de uma mulher-indivíduo até os anos 60.

Contudo, a possibilidade da mulher trabalhar fora de casa, a queda da taxa de natalidade, a instituição e o aumento do divórcio, e em conseqüência das famílias recompostas, constituíram-se dentre outras questões, segundo a autora, numa crescente tendência global para a individualização e o maior protagonismo dos indivíduos na 
construção do seu próprio destino, no campo das relações amorosas e sentimentais, trazendo repercussões no modo de se pensar e compreender a família e o casamento e de se relacionar nessas instâncias.

Desse modo, podemos perceber, por intermédio das percepções das colaboradoras sobre as formas de vida em suas famílias de origem, uma nítida diferença entre o silenciamento sobre o sexual na família de Bárbara e a abertura para tratar desse assunto na família de origem de Flor de Liz.

Prosseguindo em sua descrição, Flor de Liz diz:

Então sempre foi aberto e minha mãe sempre dizia isso 'prá gente: - "olha, vocês vão ter tudo o que o jovem quer ter na juventude” - festa, então, ela proporcionava, era uma cidade pequena, ela proporcionava 'prá gente, ela fazia, organizava bailes e festas 'prá gente 'tá sempre dançando, Carnaval a gente participava de tudo, tudo a gente participava. E ela não tinha essa coisa de dizer: "você não vai namorar”- a gente era livre 'prá não namorar, todos namoraram com quatorze anos, treze anos, na minha época a gente namorava numa boa. Minha mãe nunca foi aquela de prender, "não, eu quero saber quem você 'tá namorando, você quer namorar na pracinha você vai namorar na pracinha, eu não quero você pelos cantos”. Mas a minha mãe sempre foi muito liberal e meu pai também. Então ele dizia: "eu quero que vocês curtam tudo agora, se tiver que namorar sente e namore e sente, a única coisa que eu peço é pra vocês não perderem a sua dignidade, como mulher, isso eu não quero, de ficar alguém falando mal, de perder a sua moral.

Percebemos no discurso acima que um diálogo sobre a sexualidade se estendia na família de origem e que o respeito aos filhos como indivíduos dotados de responsabilidades próprias e capacidades de realizar escolhas pessoais era mantido.

Continuando, revela como seu pai percebia o casamento, naquela época:

"Casou, casou, tem que ser fiel ao seu marido, agora se você não gosta mais de seu marido chegue pra ele e fale: 'não quero mais viver com você, não gosto mais de você e quero ser livre” e pode namorar quem você quiser, solteira. Minha 
filha, desquite 'tá aí, divórcio 'tá aí. É pra isso, então, não tem necessidade de mulher casada trair marido”. Então, meu pai nunca foi contra desquite, contra divórcio, mas nós somos travadas.

A compreensão de uma mulher-indivíduo, que tem o direito de realizar escolhas pessoais, implica numa liberdade em relação à vida amorosa e à submissão masculina. Ao poder realizar uma escolha do parceiro, a mulher passa a ter o direito de decidir também sobre ficar ou não com ele, contribuindo para um redesenhar das relações afetivas, no âmbito dos gêneros, resultando em novos modos de subjetivação feminina.

A colaboradora relata ter se casado inicialmente no Civil, pois na época em que se uniram, ela havia perdido a certidão de batistério, de modo que casaram-se na Igreja somente dezoito anos depois, quando ingressaram no "encontro de casais”, sentindo por isso um dever moral de cumprirem uma regra religiosa.

Ao ser indagada sobre a relação afetiva e sexual no casamento, antes da vivência da infidelidade amorosa, a colaboradora não relata as suas vivências sexuais, mas fala sobre a vida afetiva do casal no início do casamento:

Quando eu me casei eu não amava meu marido, eu era apaixonada por ele, havia uma diferença, eu não amava, eu tinha muita dificuldade de amar alguém. Eu era assim, uma pessoa muito... até hoje apegada com as pessoas [...] mas com relação a ele eu ainda não amava meu marido e eu aprendi a amar ele com os anos que eu fui convivendo com ele, porque existia uma cumplicidade muito grande da parte dele em relação a mim. [...] ele era meu cúmplice nas coisas que eu queria fazer, às vezes meus alunos 'tão passando fome, não tem o que comer, ele dizia: “tá, eu ajudo, vamos embora” - ele ia comigo, saía, comprava cesta básica... de tudo, pra passar o mês inteiro: “vamos, vamos levar na casa dele” - [...] ele me ajudava em tudo, tudo que a gente tinha vontade de fazer e tudo o que ele queria fazer eu ajudava, havia uma cumplicidade, ele começou a me conquistar, Edilaine, eu comecei a me apaixonar por ele, depois da paixão virou amor, aí quando vira amor é que você tá babando. 
Seu discurso revela a existência de uma relação conjugal pautada na cumplicidade, na solidariedade e no companheirismo, construída no decorrer dos anos, a partir da convivência do casal. Esses elementos vão ao encontro do que Torres (2000) denominou de “amor construção”, que implica ,dentre outras características, na descoberta de novos elementos na relação amorosa depois do casamento e em maior paridade entre os gêneros.

Prosseguindo em sua descrição, a colaboradora expressa ainda o respeito ao outro e a valorização pela pessoa do outro, como podemos perceber no relato abaixo:

eu tinha uma admiração muito grande por ele, eu me orgulhava do marido que eu tinha, que por ele não ter estudado, ele só fez o colegial, por ele não ter estudado, ele era um homem que era capaz de sentar com você e falar qualquer assunto... de filosofia, de história, de discutir sociologia, política.

No decorrer de sua descrição, Flor de Liz relata sobre a gravidez do segundo filho do casal, momento em que pela primeira vez seu parceiro lhe foi infiel:

A primeira [refere-se à primeira vez que o marido lhe foi infiel] quando eu descobri eu fiquei chateada, eu chorei muito, nossa, como eu chorei! E teve uma coisa que foi boa pra mim porque foi um período, teve uma coisa boa nesse momento que fez com que eu superasse mais fácil: meu filho tinha nascido. A Marina tava com cinco anos e tinha nascido o meu filho [...]. Foi na minha gravidez [a infidelidade]. Então, foi quando ele nasceu que eu descobri isso [a infidelidade do marido], então, eu tive uma coisa boa pra ocupar a minha cabeça, eu tava cuidando do meu filho pequenininho, aquilo ali é como se fosse uma terapia.

Esse relato encontra convergências com as descrições de Isolda e Stela, que também relataram sobre as traições dos maridos no período de gestação dos casais. Os mesmos sentimentos relacionados à completude da relação mãe-bebê, vivenciados por estas colaboradoras, são também manifestados na descrição de Flor de Liz, ao afirmar que cuidar 
do filho, “doar-se a ele” no mesmo momento em que descobre que o marido lhe é infiel é uma “terapia”.

A colaboradora diz que Miguel assumiu-se culpado pela infidelidade e se desculpou.

O fato de você assumir: - "Eu fiz isso mesmo, me perdoa?. Eu quero viver com você”. Isso te deixa melhor e eu era apaixonada e quando você está apaixonada você fica cega, então eu fiz uma proposta pra mim mesma... Ele falou: 'Flor de Liz, vamos esquecer isso que eu prometo nunca mais fazer”. [...] eu fiquei dezenove anos sem nunca tocar nesse assunto. Eu nunca falei: 'Você me traiu'. Quando eu fui falar: 'Você me traiu com Tita', que foi a menina que ele me traiu lá na BERENE [nome de estado] já tinha dezenove anos e foi porque eu descobri a outra [refere-se à infidelidade recente].

Segundo Pincus e Dare (1978), a manifestação do sentimento de culpa por ter traído a esposa, tal como é expresso no relato acima, é comum. A colaboradora revela ter perdoado o marido, porém, somente quando uma nova traição se repete, dezenove anos depois, sentimentos antigos são atualizados, seguindo uma lógica muito singular, a lógica inconsciente de que não há nem tempo passado, nem tempo presente.

No período que compreendeu desde a primeira até a segunda traição de Miguel, a relação se re-construiu, segundo a perspectiva da colaboradora, sendo o casal “muito feliz” nesse período.

Quando Miguel foi infiel pela segunda vez a Flor de Liz, o filho mais novo completara dezenove anos e a infidelidade veio acompanhada do "abandono" do marido e da separação do casal.

É interessante notarmos que embora o casal tenha optado por se casar na Igreja mesmo depois de morarem dezoito anos juntos, as promessas referentes à fidelidade, 
realizadas seis anos antes da traição, no pacto nupcial frente à doutrina católica, não se cumpriram.

Na época em que Miguel lhe foi infiel pela segunda vez, Flor de Liz havia ingressado na universidade, seu pai havia acabado de falecer e o casal tinha completado vinte e quatro anos de casados.

Porém, ela conta ainda sobre a relação afetiva e sexual do casal no período que antecedeu a confirmação de que Miguel lhe fora infiel pela segunda vez.

Ao desconfiar que Miguel tivesse relações sexuais fora do casamento, além de sentir insegurança ao ter relação sexual com o marido devido à possível existência de uma terceira pessoa na relação, Flor-de-Liz manifesta o medo de contrair dele uma doença sexualmente transmissível, a AIDS, como é demonstrado no relato abaixo:

\begin{abstract}
Aí eu ficava com aquela insegurança eu tinha medo de fazer amor com ele porque tava sem camisinha, eu tinha medo e não tinha coragem de dizer: "usa camisinha”, porque eu sei lá o que essas mulheres têm, sei lá com quem que eles transaram, eu não sabia e hoje com a AIDS do jeito que está, isso aí me deixava muito insegura. Então, quando eu fazia sexo muitas vezes eu não conseguia ter prazer, porque eu tava insegura eu tava com medo, eu sabia que tinha alguém, não só pela doença, que tinha uma outra pessoa também, "será que quando ele tá comigo ele não fecha os olhos e imagina a outra?” Nossa, isso aí dá uma sensação..., é como diz os homens "broxa”, não tem, você não consegue nada. Então, prá mim, isso foi horrível, foi muito diferente da outra [da primeira vez que o marido lhe foi infiel].
\end{abstract}

Podemos dizer que, embora atualmente a sexualidade e em especial a transmissão de DSTs ocuparem um espaço de diálogos em nossa sociedade, no que diz respeito aos meios de comunicação e à educação escolar, muitas vezes as informações veiculadas perdem força diante das aflições e incertezas humanas, de modo que, como percebemos no relato da colaboradora, embora saiba que o uso de preservativos é importante na prevenção 
das doenças sexualmente transmissíveis, ela não utiliza e nem conversa com o parceiro sobre suas angústias e aflições. Desse modo, coloca-se sob a dominação masculina de subserviência ao marido, como se ele pudesse ter o poder de protegê-la das desgraças mundanas.

Prosseguindo em sua descrição, a colaboradora relata que recebia muitos telefonemas “trotes” de mulheres, que imaginava que se referiam a um possível relacionamento extraconjugal do marido. Relata também que Miguel lhe ofendia muito e que discussões eram constantes no período em que Flor de Liz começou a desconfiar que ele lhe estava sendo infiel.

É importante lembrarmos que, com exceção da descrição de Bárbara, nas outras duas descrições analisadas até esse momento, de Isolda e de Stela, também notamos que a percepção sobre a infidelidade do marido é algo que transcende a sua real descoberta ou a sua confissão. Conhecimento que, como já dissemos, ocorre por meio do processo de atividade interfantasmática da família, ou seja, pelo encontro dos fantasmas individuais de cada um dos membros da família e que são próximos por conteúdos. Assim, embora não transmitido verbalmente, o segredo acerca da infidelidade é desvelado e compartilhado pelas ansiedades comuns, pelas atitudes e pelos comportamentos de cada um dos membros da família, seja o infiel ou os demais. (Eiguer, 1985).

Em sua descrição, Flor de Liz relata também que, no período em que antecedeu a sua confirmação sobre a traição do marido, começou a analisar como ele pudesse se sentir com o seu ingresso na faculdade, revelando:

Hoje nós não vamos conversar mais com diferença, aí tem uma igualdade. Então, quando ele conversava de filosofia comigo, que ele queria mostrar que ele sabia, eu tava estudando e por coincidência sempre caia no assunto que estava estudando na faculdade, então, era um assunto que eu estava estudando na 
faculdade e, ele se viu em pé de igualdade comigo. Aí ele começou, eu não sei o que aconteceu.

Flor de Liz acredita que o seu ingresso na universidade tendeu a equilibrar as diferenças entre ela e o marido no que diz respeito à superioridade do homem em relação à mulher, demarcada com a ordem patriarcal, e que ainda têm repercussões nos dias atuais. E percebemos ainda que após falar sobre seu ingresso na faculdade, ela não conclui conscientemente nenhuma relação entre a sua ida para a universidade e a infidelidade do marido ou o seu desejo de separação de Miguel.

Prosseguindo, ela diz:

pra ser sincera eu acho, isso na minha maneira de pensar, a mulher tá muito vulgar, isso também influi queira ou não, que hoje a mulher vai à luta se ela quer aquele homem não interessa se ele é casado, não interessa se não é, "eu quero e vou pegar, nem que seja só pra tirar o... dá uns maio”, como elas falam.

Podemos sugerir que ao ingressar em um novo universo, o universitário, ao entrar em contato com garotas mais novas, Flor de Liz inicia uma reflexão acerca das maneiras pelas quais as mulheres vivenciam as relações afetivas e sexuais na atualidade. Em seu relato, ela faz uma crítica às “meninas” que vão “à caça aos homens”, sendo esses casados ou não. Afinal, Miguel, um homem casado, separou-se da esposa “por causa de uma menina bem mais nova que ela”.

Prosseguindo em sua descrição, ela diz:

teve muita coisa nesse processo até chegar ele dizer que nosso casamento tinha acabado, que não dá mais, aí começa as ofensas, né?, aí ele começa a dizer coisas que você jamais imaginou que você ia ouvir e ainda vindo de quem, de uma pessoa que você tinha respeito, de uma pessoa que você..., pra ser sincera eu posso dizer que eu idolatrava, eu adorava o meu marido, então, quando vem aquelas ofensas, pra ... já está com a auto-estima lá embaixo, aí ela cai mais ainda 
e como, nossa, é a pior sensação que você pode ter, aí não é só a traição com a mulher, com a outra, é a traição também verbal, que você pensava que era feliz com aquela pessoa e a pessoa diz pra você que viveu num inferno 24 anos. Então, são várias traições, prá mim foi várias, eu não só me senti traída porque ele teve caso com uma outra, eu me senti traída também na forma de pensar dele, porque eu pensava que ele era feliz, ele mandava bilhetes pra mim dizendo que eu era "a melhor mulher do mundo”.

Percebemos que Flor de Liz atribui ao fenômeno infidelidade significados que vão além da ocorrência de uma relação sexual extraconjugal e que se referem à traição à palavra empenhada. Isso quer dizer que a co-partilha da lembrança voluntária e reconhecida do amor jurado outrora à parceira é desfeita. Na ótica de Comte-Sponville (1995), a fidelidade enquanto virtude representa um_amor fiel, conservado ao que aconteceu; um amor que é voluntariamente presente e conservado ao passado, mas que deve ser, entretanto, correspondente apenas ao amor e não ao amante.

Compreendemos, desse modo, que a colaboradora sente-se traída por causa de um “esquecimento": Miguel parece ter se esquecido que mandava "bilhetes de amor” à esposa e que dizia que "ela era a melhor mulher do mundo", dizendo agora que, "vivera um inferno por vinte e quatro anos no casamento". Por outro lado, podemos supor que ao ceder-se ao “esquecimento”, Miguel esteja talvez sendo fiel ao amor, ao novo amor.

E dando continuidade a sua descrição, ela revela os sentimentos de amor, dor e luto, decorrentes da vivência da infidelidade de Miguel, bem como da separação do casal, como abordaremos a seguir:

Flor de Liz relata que começou a olhar os "bilhetes de amor" guardados e a questionar se realmente "ele foi feliz ou ele não foi feliz”, sentindo-se com isso, confusa, demonstrando dúvidas sobre sua própria identidade, como percebemos no relato seguinte: 
“... foi uma seqüências de coisas que você começa a ficar olhando se você realmente era aquilo mesmo, porque do jeito que ele falava eu era uma 'bruxa'. Mas num momento aí, eu comecei a pensar pôxa [ênfase], se eu for me colocar no lugar dele, naquele momento, eu era uma 'bruxa'”.

Embora Miguel tenha negado que lhe era infiel, pois "Miguel morre jurando que não tem ninguém, ele vai morrer jurando que não tem ninguém”, a colaboradora diz ter confirmado a infidelidade dele: “...eu paguei pra mim saber [que ele lhe era infiel], descobri tudo, aí descobriu” e continua:

Eu só não quis saber quem era, como era, porque eu tinha muito medo de ver uma jovenzinha. Eu não sei, a gente quando chega nos “enta”, aí você tem ah::: você começa a se sentir muito insegura, eles [os homens] são mais, hoje eu sei que eles são mais... sexualidade que eles vão diminuindo... e eles não se aceitam assim, a gente [mulher] se aceita com mais facilidade. Mas na época, se eu soubesse que era uma menina novinha, eu já tinha conhecido a moça, mas na confirmação, eu não quis saber se era aquela mesma. Hoje eu sei que foi por medo de saber quem era realmente a moça, se era aquela que eu tinha conhecido, que ligou pro celular dele. Hoje eu sei que foi por medo.

Nesse relato, percebemos que em um jogo de palavras contraditórias, Flor de Liz relata “não querer ter sabido quem era a moça jovem” e também “já saber que era”. O inconsciente atualiza a fala que se contradiz e desvela as limitações e inseguranças humanas que se expressam no dito da colaboradora, que demonstra ter "medo" de envelhecer.

A partir dos relatos de Flor de Liz, percebemos quem o fato de Miguel se relacionar com uma "garota mais nova” desvela uma práxis de nossa sociedade de que os homens casados se relacionam com garotas mais jovens que eles e que suas esposas.

Prosseguindo em sua descrição, Flor de Liz relata: 
Porque ele estar com uma menina novinha, a metade da minha idade, menos da metade, "tudo encima", como diz o outro - ia falar besteira, me deu vontade... [risos] , "tudo encima”, totalmente fantasiosa, porque quando a gente era jovem, a gente é cheio de fantasias, de sonhos, coisas que a maturidade vai tirando, não vai tirando totalmente porque você tem sonhos, mas sonhos com o pé no chão, não é aquela fantasia de "príncipe encantado", e eu era uma "bruxa”, porque eu estava impedindo, querendo impedir dele viver aquela fantasia, ele achou a "princesa" dele, naquele momento ela era "princesa" e eu tinha que ser a "bruxa”, eu tinha que ser a mulher que fez ele sofrer por 24 anos.

E diante de um universo de deveres existenciais, ela desvela ter encontrado um novo papel para assumir, na história de Miguel, a representação de “uma mulher velha e má”, como demonstrou no relato acima.

Parece-nos então, que Flor de Liz se angustia não somente perante a traição, mas também perante a sua limitação enquanto um ser que envelhece e se lança, em última instância, para uma condição ímpar e ao mesmo tempo universal, a morte. Retomando Forghieri (2002), dizemos que o homem, como ser existente no mundo, nunca poderá completar-se ou totalizar-se durante a sua existência, pois, como disse Martin Heidegger “o ser total é o ser em relação à morte”, a nossa maior e mais profunda certeza.

Compreendemos com este relato que, em seu temporalizar, Flor de Liz percebe-se como um ser feminino potencialmente capaz de perder a jovialidade e tornar-se por isso, desvalorizada frente ao homem que é ainda capaz de conquistar uma garota jovem, mesmo que também esteja se tornando mais velho.

Suas vivências de insegurança encontram-se, pois, ressonantes com a "tirania do prazer” da cultura de nossa contemporaneidade, a cultura do imediatismo, da eficiência, dos “fluxos nervosos”, do totalitarismo mercantil, da valorização do belo e do novo, que 
superficializa os vínculos afetivos, atribuindo ao ser humano um valor de mercado, tal como nos descreveu Lipovetsky (2004).

Assim, o amor de Flor de Liz e Miguel, amor idealizado que prezava pela cumplicidade, pelo compartilhar de vivências, pela fidelidade e pelo respeito mútuo, foram se transformando pouco a pouco um conto em que "príncipes e princesas" se desencantaram.

O casal se separou e Flor de Liz conta como se sentiu:

Eu senti medo, angústia, expectativa, medo, medo de tudo, tudo. Medo se eu ia ter condições de manter a minha família, de me sustentar, de ficar sozinha, medo de solidão, eu só tinha certeza de não querer ninguém mais na minha vida, eu tinha medo de minha sombra. Tinha medo de tudo, era tudo, eu comecei sentir no início, eu comecei a me sentir incapaz, até no próprio trabalho, trabalhando com os meus alunos e de eu não dar conta da sala, eu não saber trabalhar, eu comecei a sentir isso, me sentir muito insegura, com relação a tudo, com os filhos muita dificuldade. A sensação que eu tinha era é que eu não era capaz de manter o controle da situação, das coisas, como controlar os filhos, manter o equilíbrio dentro de meu lar.

Sua descrição revela sentimentos de baixa auto-estima, de impotência, de solidão, de menosprezo, de auto-depreciação e de “fobia” e prosseguindo, ela relata:

A primeira sensação é o vazio, quer dizer, um buraco e some tudo no seu peito, e í você senti cair. É a primeira sensação, você fica sem chão. Então, eu tinha muito medo. [...] Sem chão? É como se eu tivesse o maior vazio, a sensação de que eu tava num lugar sozinha e não tinha ninguém que pudesse me ajudar, aquela sensação ruim de que eu sou, eu não sou ninguém. Aí é como se tivesse, depois de um tempo que eu vim perceber, é como se tivesse tirado uma perna e um braço meu, aí que fui ver a minha dependência com relação a ele, o porquê de eu me sentir sem pé e sem braço. Então, sumia... eu olhava... até às vezes eu ficava olhando assim... eu sentava no sofá... eu fiquei muito sozinha na época.... 
Percebemos que embora tenha ingressado no mercado de trabalho, seja capaz de contribuir para o provimento do lar, o projeto de vida-a-dois parece permear a idealização de felicidade para a colaboradora, pois quando este projeto se fragmenta ela se desterritorializa, “perde o chão” e, simbolicamente, o projeto de vida pessoal “desmorona”.

Percebemos, entretanto, que a manifestação de uma neurose ou sintoma de tipo histérico - a “fobia” - é expressa no discurso da colaboradora pela “sensação de vazio”, pelo “medo de cair de um lugar estático”, pelo “medo de perder o chão”, pelo “medo de estar sozinha no mundo”.

Na perspectiva freudiana, a "fobia” é também chamada de histeria de angústia e converte uma angústia em terror imotivado, ou seja, tem como sintoma central o pavor, contínuo e sem motivo, que o indivíduo sente frente a um ser vivo, a um objeto ou a uma situação que em si mesma não apresenta perigo algum.

Retomando Nasio (1997), ao perdermos o ser amado, a lesão está localizada erroneamente no mundo exterior: no desaparecimento da pessoa do amado, pois ela se situa, na realidade, no ponto em que a nossa sensibilidade mais íntima se arranca da sensibilidade do outro amado; no ponto em que a nossa imagem interior vacila, por falta do suporte da pessoa do outro; e no ponto em que o nosso sistema simbólico falha por falta do eixo que era o ritmo do casal. Desse modo, a lesão proveniente da perda do amado se situa no desabamento da fantasia, de nossa projeção, de nossa idealização e a dor nos parece tão interior que é absoluta e, às vezes, até necessária, estando conosco como substância vital.

Com o discurso acima, a colaboradora compara a dor corporal à dor psíquica no desabamento da fantasia; o que quer dizer que a dor sentida pela perda do amado, dor 
promovida pela loucura da cadência pulsional, é assemelhada pelo eu à dor de uma amputação corporal.

Na visão de Nasio (1997), a pessoa que perde um braço ou uma perna, por exemplo, sofre de um distúrbio, o da alucinação de um membro fantasma, sentindo vivas as sensações vindas do membro desaparecido. Do mesmo modo, a pessoa enlutada pode perceber, com todos os sentidos, a presença viva do amado desaparecido. “A pessoa amada é para o eu tão essencial quanto uma perna ou um braço. Seu desaparecimento é tão revoltante que o eu ressuscita o amado sob a forma de um fantasma” (NASIO, 1997, p.32).

Nessa perspectiva, o eu funciona como um espelho psíquico com uma miríade de imagens que refletem esta ou aquela parte de nosso corpo ou este ou aquele aspecto dos seres ou das coisas às quais nos ligamos afetivamente.

Continuando em sua fala, Flor-de-Liz diz:

cansei de sair, de ir em shopping com uma amiga minha, e não dizia nada prá ela, eu falava assim: "não, hoje vou olhar o moço, com olho diferente”, aí Edilaine, eu olhava... não via e ficava caçando a cara dele nos homens. Eu falava: "gente, eu desisto!”. “Não, o quê, Flor de Liz?”. Eu: “nada”. Ela: “Flor de Liz, o que você está escondendo de mim? Aí ela: "o que você tá desistindo aí? Eu disse: "não, hoje eu saí na intenção de achar um pra me paquerar e de vir... Eu tô procurando a cara daquele preto horroroso nos homens... Eu não vou achar. Ela: "Flô, não insista, você já admitiu que gosta dele, vai à luta, sujeita!”. Eu falei: “Não, à luta eu não vou não. Voltar pra ele, ir atrás dele, eu não vou não.”. Se tiver que acontecer, vai acontecer. Mas eu ir atrás dele, eu não vou, nunca mais. "Então, se você não desistiu fica na sua, não fica procurando mais ninguém não". "Mas eu estou tentando”. Porque você tenta Edilaine, não tem jeito, você tenta, tenta de todas as formas, mas você olha e não 'tá aquele moreno. Aí você fica procurando a barba, não acha a barba. Você fala: “Até que aquele homem é bonito”, mas... [risos]. É muito complicado isso, não adianta. 
Essa perspectiva teórica considera que a imagem psíquica de um braço amputado ao ser superinvestida acaba sendo projetada para fora do eu e percebida pelo sujeito como um braço alucinado, de modo que a sua expulsão deixa no psiquismo um buraco aspirante por onde escoa a energia do eu até o seu esvaziamento.

Esse mecanismo de expulsão da imagem do objeto perdido com o seu reaparecimento no real é chamado de foraclusão, o que explica a alucinação do membro fantasma, bem como o fenômeno do amado fantasma, ou seja, o distúrbio de algumas pessoas enlutadas, que alucinam o morto ou o amado desaparecido, e o vêem como se ele estivesse vivo.

Em ambos os casos, o objeto perdido - o braço amputado ou o morto continua a viver na realidade para o eu. Quando perdemos um braço, por exemplo, ou um ser querido, a imagem psíquica (ou representação) desse objeto perdido é, por compensação, fortemente superinvestida (NASIO, 1997, p. 31-32).

É justamente esse superinvestimento afetivo da imagem do objeto perdido que gera a “dor” e, num grau superior, esse superinvestimento é capaz de provocar a alucinação do objeto perdido, seja este um braço amputado ou um ser desaparecido.

Desse modo, o fenômeno do membro fantasma ou do amado fantasma não se explica mais por uma simples negação da perda do objeto amado, mas pela foraclusão da representação mental do dito objeto.

Percebemos no relato de Flor de Liz que ela não chega a ver no outro a imagem perdida do amado, como uma alucinação; o que aconteceria caso o mecanismo de foraclusão apresentado acima procedesse; mas em contrapartida, ela procura a imagem perdida do amado na imagem dos outros homens, embora não a encontre. Isso nos leva a entender que há um superinvestimento na representação mental do objeto amado, mesmo 
que ela não tenha sido de fato foracluída, ou seja, em seu extremo, superinvestida, mas sendo o superinvestimento alcançado, o processo gerador da dor psíquica.

Na visão de Nasio (1997), uma impressionante afinidade entre essas duas alucinações fantasmáticas, a perda de um membro do corpo e a de um ente querido , demonstra o quanto a pessoa amada é um órgão interno do $e u$, tão essencial quanto pode ser uma perna ou um braço e demonstra também como a alucinação, um resultado da privação do membro, transforma e transtorna o funcionamento normal do psiquismo humano.

A colaboradora diz em sua descrição:

às vezes eu ficava sentada no sofá e eu me sentia só. Eu via o buraco e eu caindo, quantas vezes eu ficava olhando pro chão, sabe quando você vê tudo negro? Não era um negro espaço físico, era o negro meu, era comigo, não tinha... eu falava: “gente, não é possível...”. Às vezes, eu cansei de não levantar desse sofá [referese ao sofá da sala de jantar] com medo, porque o buraco estava tão próximo de onde tava o meu pé, que se eu levantasse eu ia cair nele. E hoje eu tô assim, se eu levantar eu vou cair mais ainda...

Entendemos aqui que a lesão sofrida pela perda do ser amado transforma todas as referências de espaço e, assim, de identidade de Flor de Liz e que mesmo estando no atual momento, em um processo de re-construção do relacionamento amoroso, ela se sente sem referências, sem “saber por onde ir”; sentimentos que se refletem numa crise de identidade sócio-cultural que não demarca mais, os estáveis papéis de gêneros determinados na modernidade (Lipovetsky, 2004; Hall, 2002; Giddens, 1991).

Flor de Liz relata que até o momento em que Miguel e ela contaram aos filhos sobre a separação, ela ainda tinha esperanças de que o marido optasse por não se separar mais dela e revela ainda as sensações sentidas no momento em que conversaram com os filhos sobre o assunto, como veremos abaixo: 
Naquele dia, Edilaine, minha pressão foi pra 20 e nunca mais saiu. Qualquer emocional, qualquer coisa que acontece comigo, que mexe com o meu emocional, minha pressão vai para 22, e não é pressão de [risos] hipertensão, eu não sou hipertensa, é uma pressão emocional. Então, depois disso [da infidelidade e da separação], aí gente, veio tudo [doenças] [risos], eu dizia "DNA" é o "PIA": "porra de idade avançada". Tudo eu sinto, tudo eu pego, qualquer infecçãozinha eu pegava. Eu acho que o meu sistema imunológico foi pra zero porque tudo eu pegava, eu pegava grupe, tudo o que você pensar na vida eu peguei. Meu triglicéride, meu colesterol, meu ácido úrico, tudo foi lá pra cima, foi pra quase 100. Então eu dizia: "eu não vou fazer o tratamento de uma doença que não existe”. Existe um emocional abalado e o dia que melhorar eu vou melhorar.

Este discurso de Flor de Liz expressa a manifestação de sintomas psicogênicos, que se associam a "uma doença que não existe", ou seja, à situação conjugal. Uma dor psicogênica não é uma dor psíquica, mas um sofrimento corporal, mínimo ou maior, agudo ou crônico, cuja origem é psíquica.

É uma dor somática sentida pelo sujeito, sem razões orgânicas que a justifiquem, e à qual se atribui, por falta de explicação melhor, uma causa psicológica, em geral desconhecida. Trata-se de dores físicas persistentes, na maioria, erráticas e enganosas. Quando elas se fixam em um local determinado do corpo, sua localização permanece, na verdade, enigmática. Geralmente, o paciente descreve a sua dor com complacência, em uma linguagem rica em detalhes, ou às vezes de maneira confusa e evasiva. Mas o mais importante é a relação particular do seu sofrimento como se falasse de um outro, caprichoso e exigente que habitasse o seu corpo (NASIO, 1997, p.103).

Quando nosso ser é inundado por sentimentos profundos de angústia, tais como aqueles vividos pela colaboradora, como podemos perceber, não conseguimos compreender uma situação imediata e o eu não tem como reagir, senão em forma de dores psicogênicas.

A dor psicogênica é ainda, na ótica de Nasio (1997), uma expressão somática de uma pulsão freada pelo “recalcamento”, de modo que no lugar de uma “pulsão recalcada”, aparece uma dor corporal sem causa orgânica que a justifique. 
Nessa visão, se o “recalcamento” não tivesse detido o impulso da pulsão, a pulsão se expressaria sob forma de uma “dor moral”. Sendo assim, o que se transforma em dor física é, então, a transformação daquilo que deveria ter dado nascimento a uma "dor moral”.

Diferentemente da “repressão”, que tende a suprimir conscientemente uma idéia ou um afeto cujo conteúdo é desagradável, o “recalcamento”, na visão psicanalítica, designa o processo que visa manter no inconsciente as idéias e representações, que ligadas às pulsões, produziram prazer e por isto mesmo, afetariam o equilíbrio do funcionamento psicológico do individuo, transformando-se em fonte de desprazer (Roudinesco e Plon, 1998).

O “recalcamento” é ainda algo ao que não podemos ter acesso, que se remete a uma realidade que nos é inalcançável e que, por isso, faz referência ao que Rezende (1990) denominou como sentido pleno.

Sendo assim, buscando compreender o fenômeno que indagado nesse trabalho até onde nossas buscas são capazes de serem compreendidas, prosseguimos na descrição de Flor de Liz, que relata como as pessoas a trataram logo depois da separação do casal:

a gente freqüentava “encontro de casais” [reunião católica], a gente freqüentava tudo, ele cansava... tanto que elas [amigas] achavam que era eu, Edilaine, que eu que tava mentindo [sobre a infidelidade dele], que eu que tinha a mente doente, tanto que o pessoal do "encontro de casais" achava que eu era a "Heloísa da novela” [personagem muito ciumenta], chegou a me comparar: "ai, eu lembrei de você”, me encontrava no supermercado e dizia: - "ai, eu lembrei tanto de você ontem” , eu falei: “por que?”, eu achando... eu já tava com auto-estima lá embaixo na separação, "ai, porque eu fiquei assistindo a novela "Mulheres apaixonadas”, quando eu vi a Heloísa, me lembrei de você”. Olha, eu voltava pra casa um bagaço, eu cheguei ao ponto de largar o carrinho de supermercado cheinho e ir embora e não conseguir chegar no caixa pra pegar as minhas compras. Me tratavam como se eu fosse uma doente, porque ele deixava pra todo 
mundo transparecer que eu fui a doente. Ele chegou a dar diagnóstico pra mim, Se meus filhos tivessem ido pela cabeça dele eu tava internada.

Flor de Liz expressa uma auto-estima reduzida e apresenta dificuldades em realizar atividades do dia-a-dia logo após a separação. Nesse período, as pessoas perceberem-na como uma “doente”, incapaz de controlar seus afetos, e sentia-se discriminada pelas pessoas que não lhe apoiavam, mas a ridicularizavam. Aponta ainda que Miguel direcionou a culpa pela separação a ela, concedendo-lhe também o status de “doente”, incapaz e insana, porém, revela que "se não fosse os filhos, ela teria sido interpretada como uma doente mental”.

Com o relato a seguir, podemos perceber que Flor de Liz acredita que o marido tivera por ela sentimentos de ingratidão: “você já viveu muitos anos com aquela pessoa e você sabe que em todos os momentos ruins daquela pessoa você tava ali junto, não é uma cobrança, Edilaine, é de saber que está ali junto de você em um momento que você tá precisando, além de você não ter aquela pessoa do lado, você ainda sabe que ela te traiu”.

Revela que se sentiu desvalorizada pelo ex-marido e pelos outros ao seu redor, e também que a sua família de origem não discriminou Miguel e procurou acolhê-la nesse momento existencial tão doloroso. No entanto, seus familiares moravam em outro estado e assim, os encontros que tivera com eles no período pós-separação do casal foram restritos. Sendo assim, as pessoas que conviviam com a colaboradora demarcaram com maior significância, o lugar de “juízes” da situação, discriminando-a, como veremos abaixo:

a nossa sociedade é preconceituosa, então, as pessoas que tinham amizade, principalmente dos encontros de casais da igreja, é a minha religião, Edilaine, mas são extremamente preconceituosas, ignorantes, idiotas, imbecis eu falo assim de carteirinha. Eu nunca achei que uma mulher separada fosse perigo pra meu casamento, eu nunca achei. 
Ela revela que depois da separação um freqüentava o “encontro de casal” em um dia; o outro, em outro, e que ele até mudou o seu horário de freqüência nos encontros para não deparar-se com as pessoas conhecidas.

E eu acho que o encontro de casais é pra isso: não vamos dar juízo a eles, vamos chamar os dois à razão, vamos conversar. Isso pra mim é religião. Então, foi muita traição, gente, eu falei "não, isso não existe”. Aí eu tinha uma vizinha que sempre conversava comigo e quando eu separei ela deixou de falar comigo, ah gente aquilo ali me doía na alma. Eu falava "espera aí, meu marido me larga, me trai, sai de casa e eu ainda sou a que não presta?”, eu não acredito que eu estou vivendo isso.

Nesse relato, percebemos que Flor de Liz questiona os preceitos e valores cristãos, já que passa a ser discriminada pela Igreja por uma falta que não cometera e desvela seus sentimentos frente aos preconceitos e às discriminações: “Então aí que eu me trancava mesmo em casa, aí que não tinha vontade de sair. Aí eu tinha medo de sair na rua e encontrar ele na rua com outra” e tentando resolver esse drama, ela relata:

aí eu sobrecarreguei muito [refere-se ao aumento de realização de atividades desenvolvidas], eu falei: "Não existe remédio melhor pra quem tá com a autoestima baixa, pra quem tá com depressão do que o trabalho". "Então, dobra" [refere-se ao dobrar sua carga horária de trabalho diário]. Eu dobrei meu serviço. Comecei a superar... [as perdas] tanto que quando minha mãe faleceu, eu pensei que fosse ficar pior [pior do que quando o marido the traiu e lhe deixou]. Eu não fiquei. No dia que minha mãe faleceu eu fui trabalhar. No dia do enterro, eu tava trabalhando. A hora que minha mãe tava sendo enterrada, eu tava trabalhando.

A fim de lidar com mais uma perda, a morte da mãe, é evidente a utilização pelo eu de um “mecanismo de defesa”: a “negação”, o qual consiste, como já apontamos em uma tentativa de não aceitar a realidade, por seu caráter extremamente perturbador. 
Flor de Liz esclarece sobre as repercussões que a infidelidade e, em conseqüência, a separação do casal tiveram na vida dos filhos e, assim, na vida familiar, como abordaremos a seguir.

No momento da separação, Marina e Marcelo, os filhos do casal tinham 23 e 19 anos de idade, respectivamente. Marina era universitária e morava em outra cidade, enquanto que Marcelo residia com a mãe. Flor de Liz relata que ficava muito sozinha, mas que tinha "muito medo" em solicitar freqüentemente a constante companhia dos filhos.

Diz que pedia aos filhos muitas vezes para que ficassem com ela e que: "tinha a sensação que eu tava querendo substituir o meu filho pelo meu marido, na companhia, e eu não queria fazer isso”. Relata perceber também que: “ele [o filho] ia muito pra SMALVILLE [nome de cidade] acampar, eu via que ele também saia daqui pra fugir daquele clima”.

A colaboradora prossegue em sua descrição e revela que na ausência de Miguel, mesmo ele contribuindo financeiramente com as despesas do lar, ela sentiu-se sobrecarregada com as obrigações domésticas e com as cobranças materiais da filha: “a situação financeira era ele [marido] que controlava, eu tinha meu salário, o meu salário servia pra pagar a conta de telefone, servia pra mandar pros meninos, pra Marina”, mas relata ainda que: “o que era pra você [ela mesma] fazer coisa supérflua deixou de fazer coisa supérflua pra fazer o essencial”.

Após ficarem dois anos separados, Miguel e Flor de Liz optaram por reatar o relacionamento, processo no qual, no momento da entrevista completara seis meses, como já apontamos. 
Dispostos a compreender a reconciliação do casal, passaremos a outra dimensão existencial do fenômeno: a re-significação do relacionamento amoroso: reconstrução do prazer.

Quando relata a tentativa de reconstrução da relação amorosa, a colaboradora explica que mesmo tendo ficado separado por aproximadamente dois anos, Miguel nunca deixou de visitá-los, mas que havia brigas constantes entre eles: "ele me colocava no buraco do mesmo jeito eu me sentia no chão”.

Podemos dizer que os investimentos na representação psíquica do amado eleito foram constantes, demarcando muitas decepções a cada frustração que a colaboradora tinha com os comportamentos não esperados de Miguel.

Ela mantinha relações sexuais no período de pré-reconciliação e quando “ficou seis meses sem ter relações sexuais com ele” pois sentia-se magoada com as ofensas que lhe fazia, ele começou a respeitá-la mais, deixou de lhe dirigir ofensas e passou a aceitá-la melhor, de seu modo de ser.

Flor de Liz compara ainda as atitudes de Miguel antes da traição e da separação do casal com as atitudes atuais, dizendo: “ele fazia supermercado pra mim, ele cozinhava, ele fazia tudo comigo. Ele era um marido que qualquer mulher queria ter e mudou da água pro vinho, Edilaine” e, continuando, diz que: “é como se tivesse caído do pedestal, ele não é aquilo tudo....”. Desse modo, seus últimos discursos imprimem indícios de que novas representações psíquicas acerca do amado eleito, engendraram-se, que ela desinveste da imagem perdida para atribuir novos significados ao parceiro atual, criando-se novas miríades de ideal de $e u$.

Prosseguindo ainda, ela desvela: “a sensação que eu tenho quando ele ‘tá comigo, quando ele conversa comigo sobre tudo, qualquer coisa, ou sobre isso mesmo [discussões, 
humilhações, separação] que é a conversa, foi tão doloroso pra ele, foi mais do que o meu... porque eu acho que em mim doeu, mas nele doeu muito mais”. Compreendemos com esse relato que a colaboradora utiliza um “mecanismo de defesa” chamado “racionalização” que consiste num processo capaz de levar o indivíduo a encontrar motivos aceitáveis para pensamentos e ações inaceitáveis, levando-o a apresentar explicações logicamente consistentes ou eticamente aceitáveis para uma atitude, uma ação, uma idéia ou um sentimento que emerge de outras fontes motivadoras (Fadiman, 1979).

Desse modo, parece-nos que Flor de Liz procura fazer justiça ao mau comportamento de Miguel, “projetando” nele todo o sentimento de culpa sentido por ela. A colaboradora tende a percebê-lo como vítima, a fim de que seu “pecado” seja “perdoado”, isto é, seja aceito socialmente e tal como fez Isolda, busca assim, sentir prazer com o sofrimento alheio que se converte em seu, quando a “dor” do outro não é nada menos que, segundo a perspectiva de Nasio (1997), a “dor” para o eu. A “projeção” é, segundo Fadiman (1979), um “mecanismo de defesa” que visa atribuir aos outros, animais, objetos ou pessoas, sentimentos ou intenções que se originam em si próprio, deslocando aspectos da personalidade do indivíduo para a realidade exterior, com o propósito de lidar com uma ameaça externa.

Continuando, a colaboradora relata:

eu vou ser sincera com você, eu... a gente namora, eu dizer pra você que é a mesma coisa, mentira. Eu ainda tenho medo, tenho muito medo, tenho muito medo que ele venha a me magoar de novo [...] Agora estamos tentando, mas eu ainda tenho aquele medo, tenho muito medo, aquela sensação, será que ele não vai fazer tudo de novo comigo?, e eu vou sofrer tudo de novo? Hoje eu sei que eu não vou sofrer como eu sofri, porque eu não fiz dele o meu braço e minha perna, hoje eu ando com minhas próprias pernas e trabalho com os meus próprios braços, mas eu fiz isso [andar com as pernas dele e trabalhar com os braços dele], são 26 anos. É difícil você mudar do dia pra noite, o seu comportamento, as suas 
atitudes, sua maneira de ser, de viver, é muito difícil do dia pra noite você mudar, isso é que muito complicado.

Compreendemos aqui que a relação amorosa é re-significada, rumo a um novo investimento dos parceiros no casamento. Entretanto, o “medo” relatado pela colaboradora demonstra nada mais, nada menos, que a reatualização constante de sentimentos e vivências passadas, feita pelo inconsciente, que é um saber que não cansa de atualizar acontecimentos passados em vivências presentes (Nasio, 1993). O “namoro” ao qual Flor de Liz se refere remete à coabitação separada (Vaitsman, 1985), o comportamento de alguns casais contemporâneos que, na tentativa de preservar a relação, ou seja, minimizar as dificuldades inerentes à vida-a-dois, optam por morarem separados, assim como percebemos na vivência relatada pela colaboradora.

Flor de Liz esclarece ainda que, no processo de reconstrução conjugal, ela procura se valorizar enquanto mulher e ser humano. Afirma que independentemente de haver ofensas, a separação é um processo doloroso, que a auto-estima e a dignidade humana “afundam” e que por isso: “você tem que ‘desenterrar’ 'pra poder começar a tirar de novo”. Esse relato desvela que o ser humano tem a capacidade de se reerguer de uma situação que outrora, lhe desestruturou, mas que para isso, deve buscar o reerguer de sua auto-estima, que podemos dizer ser pautada no referencial de Nasio (1997), uma reestruturação de sua auto-imagem, de seu psíquico eu.

Ela afirma que concedeu outros sentidos à vida material familiar, procurando não necessitar exclusivamente do dinheiro dele, como é demonstrado abaixo:

Então, eu fui fazer biscuit, eu fui bordar, eu fui fazer ponto-cruz, eu me viro, tem mil e uma forma de você ganhar dinheiro [...] o que meu braço alcança, se minha vida é essa, é essa vida que eu vou ter, se eu não tenho dinheiro pra sair, pra viajar eu não vou, o dia que tiver vão [...] tem que ser, tem um limite e depois, dali a pouco ele arruma outra mulher, casa e eu? Naquele mau costume? 
E percebemos assim que a imagem da "mulher dependente afetiva e financeiramente do marido” é convertida na imagem de uma mulher que prima pela afetividade na relação amorosa, mas que não a tem como única meta, ela também visa a felicidade pessoal, que não parece ser agora buscada somente no casamento, mas em outras relações com o mundo ao seu redor.

Quanto à reconstrução da relação amorosa, embora mais realista que no passado, é diante da possibilidade do ser humano projetar-se para o futuro que a colaboradora vislumbra novos horizontes, permeados pela ordem do desejo, fantasias e idealizações de felicidades a dois:

eu queria acabar minha velhice com ele [...] ver nós dois velhinhos, eu fico imaginando nós dois velhinhos dando 'cascudo' [gíria regional que se refere a 'bater de leve na cabeça de outrem] nos netos [...] eu me vejo correndo atrás dos netos, brincando com neto com ele [parceiro] [...] eu tenho expectativa que ele fala: "quer ir embora 'prá BANANA [nome de estado] de volta [...] a gente volta, compra uma casa na beira da praia?!”.

E revela: “então agora eu me vejo fazendo planos que já faz dois anos eu não faço”, desvelando que novos investimentos podem ser refeitos, à medida que o eu se fortifica, após passar por um doloroso processo de perda. Contudo, ela diz: “vamos fazer as coisas devagar, vamos ver se isso vai dar certo mesmo da gente ficar junto”.

eu peço a Deus me dá saúde, segura na mão Dele e vai, que Ele vai mesmo e Ele carrega, então, a única coisa que eu faço é isso [rezar], e vâmo tocando, vâmo ver no que é que dá, agora tar criando [risos] fantasia... eh::: fico toda fantasiosa, me vendo na praia come ele andando junto.

É interessante notarmos que de modo tão diferente das demais colaboradoras, cujas vivências foram emergidas na dinâmica do ressentimento, Flor de Liz perdoa o parceiro e ainda busca realizar-se na relação. Ela diz que o difícil é “você lidar com o novo, o difícil é 
você lidar com uma situação nova”, o que desvela o quanto o “velho” foi re-significado, isto é, as suas percepções sobre o quanto o parceiro se modificou, que a relação amorosa se modificou e que ela não é mais ela mesma, e revela que o casamento: “é uma aprendizado, você vai aprender a dividir tudo o que é seu, dividir a cama, dividir a gaveta, a pasta dental [...] é o maior crescimento que o ser humano pode ter”.

Hoje eu descobri que a felicidade não é no outro [parceiro] que eu vou encontrar, a felicidade 'tá dentro de mim, o outro é só um complemento. E que é muito gostoso é [refere-se ao casamento]. Se ele não tivesse voltado eu ia viver a mesma coisa. Não é porque ele está querendo retornar pra casa que eu tô dizendo isso. Se ele não tivesse voltado eu já tava pensando: “é muito bom, o meu não foi até o fim, mas... o quê que eu posso fazer?”. E olhe, é muito bom amar alguém é a coisa melhor do mundo, não tem coisa melhor no mundo do que você amar alguém, amar é a coisa mais linda que tem, viu? Pode crer, com certeza. [...] pode amar dez, pode amar um, mas se amar um já ganhou.

Com esse relato, Flor de Liz encerrou a sua descrição desvelando que embora tenha vivenciado o sofrimento psíquico na relação a dois, os momentos de satisfação advindos do casamento não precisam ser invalidados, que é necessária a auto-valorização para o ser humano e que as relações amorosas são importantes em nossa existência cotidiana, embora constituírem-se em somente um complemento.

Passaremos a seguir, à compreensão e interpretação da descrição da temporalidade de Verônica frente ao fenômeno da infidelidade e da re-significação do relacionamento amoroso. 


\section{Verônica}

Entrevista realizada em 30 de Março de 2005.

Verônica tem 59 anos e seu parceiro 53, é casada há 29 anos no civil e no religioso, casou-se aos 30 e seu marido aos 24 anos. A religião do casal é católica. O nível econômico da família corresponde à classe A2. Eles têm um filho com 28 anos e uma filha com 26 anos. Verônica possui ensino superior completo e João, seu marido, possui pósdoutoramento. Ela trabalha na área da saúde e ele na área da educação. Verônica relata que no decorrer do casamento, João lhe fora infiel em dois momentos, relacionando-se com mulheres que conviveram com ele em seu ambiente de trabalho. Revela que em momentos tristes e de indecisão em relação a separar-se ou não do marido, ela rezava muito e acabara por optar por reconstruir a relação amorosa, relatando estar muito feliz atualmente por ter continuado casada com ele.

Em sua descrição, Verônica se mantém silenciosa em relação a sua adolescência, juventude e namoro, mas desvela sobre os encantos e desencantos do casamentos antes de João lhe ser infiel, apresentados nos relatos que seguem:

Eu sempre considerei o relacionamento ... sempre .... o relacionamento afetivo e sexual no casamento muito bom, muito bom. Nós nos entendemos muito na parte sexual, né? Foi bastante intenso no casamento nesse aspecto [...] depois de casado surgiram brigas de adaptação, mas sempre a gente nunca dormia mal, sempre fazíamos as pazes, como até hoje ... é difícil a gente ficar muito um... cortando o relacionamento com o outro, né? Uma coisa que não dura muito... nosso afastamento, né? [...] Sentimentos de amor, manifestação de carinho, não é? Eu acho que isso..., é como eu disse pra você, nós temos uma facilidade pra fazer as pazes, sabe?, a gente tá sempre se pegando, sempre se abraçando, sempre demonstrando esse carinho, mesmo que as coisas não estejam muito bem, não sei se os dois são muito “fogueiro”, eu não sei, é... acho que até mais o meu marido. 
Percebemos com o relato acima que Verônica e João são um casal muito afetivo, e continuando em sua descrição, ela revela sobre alguns aspectos da personalidade de ambos, demonstrando que embora discussões sejam comuns na vida do casal, eles sempre procuram fazer “as pazes":

ele... não tem esse negócio de passar no corredor perto dele e não falar "bom dia”, não é ? Ele puxa e "bom dia”, não é? Com tudo aquele jeito dele de fazer as coisas, nisso ele é muito mais afetivo, mais é... mais presente, né ? Então, eu acho que nisso que eu ando mais devagar de fazer as pazes, "deixa como é que pra ver como é que fica”, não tem isso, ele não deixa, "por que que você tá bravo?”, né ? Ele não fala se ele tá bravo: “eu não estou bravo, quantas vezes eu vou ter que falar pra você, eu estou bem”.

Verônica relata ainda que antes de João lhe ser infiel, o casamento deles "era uma namoro, né? com muita aproximação, muito carinho no olhar, tudo né ? Afago...” e em seguida, inicia a sua descrição desvelando sobre os sentimentos de dor, amor e o processo de luto empreendido na vivência da infidelidade do parceiro.

A colaboradora relata que já faz mais de vinte anos desde quando João lhe foi infiel pela primeira vez, período em que o filho do casal faria a primeira comunhão, e revela como João modificou o seu comportamento para com ela:

Eu estranhei muito porque ele começou a mudar, não olhava nos meus olhos, começou a por mil defeitos, né? e eu fiquei: "nossa, tem alguma coisa errada, o quê que é...?”. Mas a gente não sabe, eu falava: “ah ... esperar”- , eu tava mudada, eu tava bastante atarefada com a minha formação, fora de BETERRABA [nome de cidade], trabalhando bastante, então, tinha bastante reclamações e... [...] eu não achava que tinha ninguém na história, né?, achava que o meu casamento tava acabando, né?

Compreendemos com esse relato que o afastamento emocional e as ofensas para com a parceira são comportamentos que podem ocorrer em um contexto no qual uma terceira pessoa se faz presente na relação do casal, assim como vimos nas descrições das colaboradoras anteriores. 
Percebemos ainda que Verônica se “culpa” por temer a perda do objeto amado, temor que no momento relatado habitava mais as suas fantasias do que a concretude da realidade.

Assim como percebemos também nas descrições das demais colaboradoras, a existência da infidelidade num grupo familiar se desvela muito antes de que seja relatada pelo próprio infiel, pois, embora Verônica dizer que “não sabia” o que podia estar levando João a mudar o seu comportamento para com ela, podemos afirmar mais uma vez que a atividade interfantasmática, ou seja, o compartilhar de medos, ansiedades, expectativas, mitos, entre outros elementos, é uma constante em nosso meio familiar e também nos demais grupos humanos (Eiguer, 1985).

Prosseguindo em sua descrição, ela diz que: “o sofrimento era muito intenso, ele sempre tinha que ficar estudando, tinha que ir muito pra faculdade então ... tava muito frio da parte dele, né? [refere-se ao aspecto sexual] e eu queria saber, eu perguntava e ele não tinha, não tinha nada, ele ficava estúpido, ele desviava” e ao manifestar a sua fé cristã ela relata que: "um dia eu rezei, ajoelhei no meu quarto e pedi pra Deus: 'eu quero saber o quê que tá acontecendo na minha vida’, pedi assim: ‘eu quero saber hoje, meu Deus, eu não tô entendendo nada'”- e prossegue dizendo como descobriu a infidelidade dele:

eu fui na sala e ele tava escrevendo uma “coisa” [uma carta de amor], quando eu cheguei ele chamou a atenção que ele ia escrever, ele escondeu...[...] foi um escândalo: "eu quero ver isso senão eu chamo a polícia”; “cê acha que tem cabimento chamar a polícia 'prá ver uma carta ...?. E eu vi, foi uma "baixaria”, mas eu quis ler a carta e a carta era uma "cartinha de amor” pra uma colega da faculdade, né?, uma professora que ele tava eh::: eh::: “sentindo muito não poder abraçá-la pelo aniversário” e aí veio a história que ele tava gostando dessa pessoa, né? Nós brigamos a noite inteira, brigamos a noite inteira, eu mandei ele embora, aquela 'baixaria’ toda né?; “mas eu não vou embora, mas eu não vou embora, que isso, que isso, né?” 
Compreendemos com esse relato que Verônica interpreta como traição o fato de João estar escrevendo “uma carta de amor" e revela que reagiu agressivamente, pois, afinal, o amado eleito que correspondia a fortes expectativas do ideal do eu, ao deixar de cumpri-las, fere o eu que tende então, de acordo com a visão de Caruso (1986), a agredir o outro a fim de que possa continuar existindo.

Ela relata ainda que: "eu acho que não chegou a ser uma intimidade sexual. Não sei se eu quero acreditar nisso, não é? Mas... eu acho que a intimidade da amizade e afetiva ela... mesmo que não tenha o aspecto sexual, ela invade a vida da gente quando ela é muito profunda, né?”.

Percebemos nesse discurso que a infidelidade assume, nesse caso, aspectos referidos por Zampieri (2004) como a quebra do pacto de se compartilhar todas as experiências com o parceiro, seja em suas vivências ou em seus relatos.

Assim, Verônica sente-se traída por não ter tido conhecimento do relacionamento que o marido tinha com uma colega de trabalho e, mais ainda, por ele tratá-la com afetividade.

É importante apontarmos que a vivência descrita pela colaboradora é diferente daquelas descritas por Isolda e Bárbara no que diz respeito aos significados que "a outra mulher” pode ter assumido para o marido.

Enquanto Tristão e Antônio relataram para as esposas que as relações sexuais que tiveram fora do casamento não eram estabelecidas por vínculos afetivos, João é flagrado numa relação afetiva com outra mulher que não é sua esposa, numa "suposta relação de amor”, na perspectiva da colaboradora.

Prosseguindo, a colaboradora relata que foi um período de “muita desconfiança”, de “muita dor” e, embora tenha negado que possa ter havido um relacionamento sexual 
entre João e a "colega de trabalho”, Verônica revela que foi até o serviço desta pedir para que ela transferisse seu emprego para uma outra cidade. Relata que até que isso ocorresse, o que levou dois ou três anos, "ela perdera o sossego" e "ficava com medo de perder o marido”: “ele saia pra trabalhar, eu definhava, né?”.

Nesse período, embora ela e João tivessem se reconciliado e ele sempre procurasse “agradá-la”, ela ficou muito desconfiada: “porque eu comecei assim... olhar nos bolsos, olhar, fazer aquela... aquele "perseguimento mais triste do mundo" que é ver o que anda acontecendo, né? Via agenda... demorou pra eu parar com esse tipo de coisa”.

Esse relato exemplifica a utilização de um "mecanismo de defesa” chamado “formação reativa”, que, segundo Fadiman (1979), é um mecanismo que substitui sentimentos e comportamentos que são diametralmente opostos ao desejo real, correspondendo a uma inversão clara e em geral inconsciente do desejo. Sendo assim, embora a colaboradora desvele que sua atitude era uma espécie de um "perseguimento mais triste do mundo”, parece-nos que embora desejasse, ela não conseguiu parar de fazêlo.

Continuando, Verônica estabelece uma ligação entre a traição e a inominável dor psíquica tão irrepreensível pelo eu:

É o sonho da gente né ? É um sonho né ? que só acontece na casa do outro. A infidelidade é um horror, mas só acontece na casa com os outros, não com a gente. E realmente eu considero um horror, muito doloroso, é uma dor inominável... Se houver dor psíquica maior do que essa eu ainda não conheço, não é ? Claro, tem que ter, mas essa até hoje na minha vida muito grande.

Ela afirma: "é luto mesmo que a gente vive, é a perda do que era, do sonho [...] é toda dor de luto, um sentimento de perda, uma hora é raiva, cê quer bater”.

Desse modo, os últimos relatos mostram o desabamento do ideal de eu, que ao realizar um "luto", a partir da perda simbólica do outro, resultando na catastrófica 
mutilação psíquica do $e u$, desencadeia o surgimento do desespero e da incredulidade (Caruso, 1985).

Manifestando a fé crista, Verônica relata ainda que buscou a ajuda de um sacerdote a fim de compreender a situação vivenciada. Este lhe aconselhou a não tornar pública a infidelidade do marido, dizendo que eles poderiam certamente ainda se reconciliar: "foi bom outra pessoa ter essa perspectiva e estar falando, porque muitas vezes eu senti que num seria capaz de ficar completamente bem, deixar essa história pra traz, né?”.

Passados seis anos da primeira vez que fora infiel a Verônica, João teve um novo envolvimento com uma secretária que, segundo a colaboradora, "o tratava muito bem”, “até lavava as suas roupas”. Relata que começou a desconfiar que o marido pudesse estar envolvido com essa moça: “o olhar do marido é denunciador, desvia o olhar e começa a dar uma esfriada [refere-se ao aspecto sexual]” e que também sofrera como da primeira vez, mas que não brigaram muito e nem ao menos conversaram muito sobre esse assunto.

Continuando sua descrição, a colaboradora relata que brigava muito com o marido, que o tratava mal, que não o ouvia e ainda diz que:

Eu acho que teve um tempo que... como eu tinha me distanciado, antes de eu saber [desconfiava, mas não tinha a confirmação de que ele lhe era infiel novamente], eu procurei mais, 'né? [refere-se a procurar ter mais sexo no casamento]. Eu achava que eu tinha provocado o esfriamento dele, né? Por causa de estar sempre cansada, sempre viajando, sempre cansada, então, eu comecei a cuidar mais, a tentar estar mais disponível, ficar realmente mais descansada, ficar com ele, não me ausentar tanto, né?

Compreendemos com esse relato que Verônia se “culpou” pela traição de João e prosseguindo em sua descrição, como buscou a realização sexual do casal, ela se contradiz, utilizando o "mecanismo de negação", acreditando que o marido possa talvez não ter mantido relações sexuais extraconjugais com outras mulheres:

eu acho que sexualmente, o meu marido não teve outra pessoa, por que ele me procurava regularmente, apesar de não ser o mesmo calor, mas a freqüiência era 
igual, não é? Tinha necessidade de sexo e a gente tinha... [fazia sexo] e a gente tinha boa qualidade, mas ele virava logo de costas, não é? porque eu vou dormir, vou dormir, sem muito beijo... [pausa de 07 segundos].

Percebemos com as vivências relatadas que a colaboradora não vê a relação sexual no casamento como uma obrigação conjugal simplesmente, mas como uma satisfação a dois. Porém, suas idéias acerca do sexo se implicam na crença de que amor e sexo andam juntos e se fundamentam na idealidade de um amor exclusivo, visto que ela diz acreditar que, “se há sexo em casa, o marido não necessita procurar fora” (Giddens, 1993; Lins, 1997; Costa, 1998).

É interessante dizermos que, apesar de Verônica afirmar que a segunda traição de João ter sido tão dolorosa quanto a primeira, ela se mantém ao longo de quase toda a duração da entrevista, relatando sobre a primeira vez que o marido lhe foi infiel e sendo assim, ela ainda diz:

Olha, eu me lembro de me sentar numa cadeira na varanda e ele olhando numa janela lá, né? E eu não queria ver a cara dele, então era como uma dor física mesmo, olhar pra cara dele e pensar nele escrevendo uma cartinha de amor, falar que ele tava gostando da pessoa, “nossa senhora”. Eu me sentia apagada, sabe? Profundamente entristecida, eu não tinha vontade de fazer nada, eu... abusei um pouco dos calmantes, não é? Mas veio com uma indicação de psiquiatra mesmo, pela tristeza exagerada... acho que é isso, né ?

Percebemos que além de retornar à descrição da primeira traição ela diz que necessitou fazer uso de drogas ansiolíticas e ainda assemelha a dor psíquica à dor física, tal como o fez Flor de Liz.

Prosseguindo em sua descrição, percebemos que, buscando justificar a traição de João, a colaboradora demonstra utilizar mais um "mecanismo de defesa", a "racionalização":

Eu acho que ele casou novo, meu marido casou com vinte e três anos, né ? Os pais eram muito severos, ele num saia com ninguém, entendeu? Então ele saiu da casa dele pra casar e depois quando ele teve a oportunidade de sair a trabalho 
ele curtia isso, eu sabia disso, que ele se sentia como um "passarinho”. "Vai dar pra voar, né ?”

Continuando, Verônica desvela sobre a relação entre a dinâmica da infidelidade e os filhos.

Verônica relata que os filhos, ainda crianças, presenciaram a briga dos pais quando ela vira o marido escrevendo "a carta de amor": "as crianças acordaram, assistiram todo esse show [ênfase], não sabiam o quê que era, né?”. Em seguida, contraditoriamente, ela afirma que "os filhos sabem”, isto é, são capazes de apreender o que acontece dentro da família, na expressão do que Eiguer (1998) chamou de transmissão psíquica familiar, como percebemos no relato abaixo:

os filhos notaram o nosso, o nosso casamento, no dia do aniversário do casamento do ano passado o menino falou, né? - “é... eu tenho muito a aprender com os meus pais porque eles venceram muitas crises, não é? E foram nos ensinando a vencer as crises e continuarmos vivos com carinho.” Ele falou no meio de todo mundo, de tudo os convidados, eles [os filhos] vêem tudo não é? Uma vez o meu filho falou: “eu não gosto do jeito que o meu pai faz com você, isso me magoa” - essa história de ir, de viajar...

Prosseguindo, ela continua o seu discurso dizendo: “olha, Alfredo, eu já sofri muito com isso, mas hoje você pode ter certeza que isso não tá me machucando mais” e percebemos que com esse discurso que Verônica, ao "racionalizar” novamente, procura não criar desavenças entre o filho e o marido e assim, tenta "proteger" o nicho familiar. “A gente não chora por causa dos filhos, esconde... depois a gente pára de ter dó da gente, ‘ai... preciso parar com isso’”.

Percebemos que a colaboradora se preocupa em manter a família intacta, unida,e também em não ficar sozinha, no que diz respeito aos cuidados com os filhos, como podemos notar na descrição abaixo:

acho que foi uma resolução "eu quero viver bem, eu não quero derrubar o meu ninho”, triste ou não, é ter a alegria de volta, fazer o quê ?. Eu não queria 
desmanchar a minha casa, não é? Eu achava muito mais vantagem em viver com ele, mesmo a gente não tendo... eu tive essa decepção, o temperamento dele... do que não. Eu acho que tentei, sabe? dividir a minha vida... um futuro sombrio carregando todos os pesos da vida, casando de novo... domingo um filho na casa de um, no outro na casa do outro, eu falei: “eu não quero isso, eu não sei quanto me custa, eu não sei se a dor que eu sinto vai passar, mas eu não quero, eu não quero viver contra” [pausa de 7 segundos].

Seu discurso desvela assim, as nuances de um casal moderno que, embora siga um padrão tradicional de manter o casamento intacto, procura dividir entre os gêneros, as tarefas domésticas.

Sendo assim, passaremos para outra dimensão existencial do fenômeno, o processo de re-significação do relacionamento amoroso: a reconstrução do prazer.

Verônica relata que:

esse assunto [a infidelidade] voltava na agenda, mas depois a gente mesmo vai vendo que não adiante ficar falando isso. É parar, não é?... de ficar falando isso [sobre a infidelidade], às vezes até sentir um "mal estar”, uma lembrança, mas procurar não ficar brigando toda hora também, senão vira um inferno sua vida. Tudo um processo que cada pessoa tem que aprender a sair sozinha, com alguma ajuda dos outros, mas a sair sozinha, né? E saúde pra passar por essa crise, né? É como se você tivesse que "nadar sem nunca ter caído na água", não é? Porque aí... é depender de tanta coisa, do amor do outro, realmente da escolha do outro, porque é essa mesmo, continuar com a escolha que ele fez.

Compreendemos no discurso acima que na perspectiva de Verônica é importante sentir a dor, um “mal estar”, mas é necessário também ter um esforço próprio para esquecer a traição, esforço que se engendra na própria saúde psíquica do indivíduo.

Por outro lado, compreendemos que em sua percepção, a continuidade da relação amorosa depende também do amor do outro, da escolha do outro, que somente ele é capaz de fazer. Isso quer dizer que a reconstrução do relacionamento amoroso é um processo que envolve o desejo e o empenho de ambos parceiros conjugais. 
No que diz respeito as suas atitudes, Verônica relata que, embora sentisse vontade de brigar com o marido, de "resolver” uma crise conjugal, ela "ficava quieta, não brigava, esperava a dor passar, aquela... ele volta, né?”, apoiando-se em sua fé religiosa, como percebemos na descrição abaixo:

nesses momentos é... mais tristes, obscuros e de indecisão [refere-se à infidelidade e aos momentos de crises conjugais], eu sempre rezei, né? [...] Então, eu sempre tive na Bíblia uma palavra norteadora, uma vez, eu diria... eu 'tava com muita raiva: "eu não quero saber mais, eu não agüento ver ele ir trabalhar todo perfumado” não sei se era encontro, né... ? O ciúme descontrola, eu vou pôr um fim nessa história, eu nunca mais acho que vou confiar, eu quero que ele vá pra China, né? E a palavra [refere-se a palavra da Bíblia] que veio foi: "A mulher sensata constrói a sua casa e a insensata destrói a sua com as mãos." Então, “coisinhas” assim [...] que vão se juntando e... é por aqui, é por aqui, não é?

Prosseguindo, ela revela: “fomos voltando devagar, voltando a ficar mais 'ternurento', sabe? Um casal com muita demonstração de ternura, ele começou a me presentear, né? E eu também, comecei a prestar mais atenção na vida dele, a valorizá-lo né?”.

Percebemos que ao re-significar a construção, o jeito afetuoso que o casal tinha, segundo a colaboradora, no início do casamento é de um lado, resgatado e, algumas características no que diz respeito ao modo como ela tratava o marido são, de outro, mudadas, pois ela passou a ser mais atenciosa com ele e a valoriza-lo mais.

Continuando, ela relata também que o casal é capaz de curtir a própria solidão do final de semana:

Os filhos saem e a gente vai namorar, não é? Depois a gente vai passear, janta junto, namora. Então nós chegamos a falar como deve ser gostoso envelhecer junto, não é? Então parecia que tudo bem, né? Eu acho que... eh::.... ele anda mais de casa, durante muito tempo um desejo muito grande de viajar, de passear, né ? E parece que não queria me levar, é como se faltasse isso na vida dele e que ele queria fazer isso sozinho, mas agora ele tem voltado a querer fazer as coisas comigo. 
Esse relato desvela o prazer sentido em compartilhar as vivências do dia-a-dia e desvela também que logo após a primeira infidelidade, “o relacionamento sexual do lado dele melhorou duzentos por cento de repente, não é? [...] não sei se é porque tava com medo de me perder, né?”, mas que atualmente: “nós ‘tâmo meio ‘pacatão’, também com sessenta anos cê quer o quê? [risos]. Os dois com pressão alta, colesterol, fazendo plano de saúde, né? Mas é normal de fim de semana, tem sexo no fim de semana, por que durante a semana parece que tá escrito "não dá” [risos]” e demonstra buscar aceitar com naturalidade o próprio envelhecimento.

Por outro lado, Verônica diz que ao compreender que em alguns momentos, o parceiro deseja estar só, ela encontrou prazer em outras atividades, que não são realizadas com o marido, como percebemos no relato abaixo:

\footnotetext{
Eu tive essa sabedoria de falar [...] é necessidade dele de fazer isso e eu também aprendi a viver também nesses momentos, né? Eu aproveitava também pra fazer os meus cursos, meus cursos de pintura que eu gosto muito, fazer as coisas que eu gostava de fazer sem ter o marido junto. Até hoje tá bem claro isso, tem muita coisa que eu faço que é bom e que não é com ele, não é, e ele também, existe um respeito por isso, sem que isso signifique: "eu não quero mais você", de repente dá uma saudade, tem que estar junto, tá junto, tá junto de novo, mas... é... [pausa de 8 segundos]
}

Esse relato desvela, pois, a tentativa de conciliar os projetos individuais com os projetos do casal ou da família (Salém, 1992).

Relata ainda que são muito prazerosas as viagens que eles vem realizando juntos, atualmente, e ao perceber maior cumplicidade do marido nos dias de hoje, ela diz: "então ele... é um ‘maridão', e no passado ele sempre foi muito cuidadoso comigo, mas ele tinha isso, ele gostava de curtir alguma solidão fora, né? [refere-se às infidelidades]”.

Compartilhando com as mesmas idéias relatadas por Flor de Liz, a colaboradora afirma: “vale a pena você tentar continuar a sua construção, a construção do casamento, eu 
me sinto mais forte, eu acho que a gente tem um ganho por isso, é difícil explicar isso pra você, eu não sei como passar”.

Prosseguindo, demonstra a sua satisfação por ter continuado casada:

Quando eu vejo a gente [família] assim tudo junto no almoço, todo mundo conversando, dando risada, todo mundo junto, vêm as namorada em casa, os filhos... eu falo: - "ai que bom 'tá todo mundo junto” -, é bom, é prazeroso, eu falo: - "se tivesse cada um ido pra um lado não ia ter" e agora é envelhecer juntos, né? Já tâmo começando a falar disso. De vez em quando ele fala assim ‘prá mim: “nós tâmo velho!” , eu falo: “ah? ... velho? Só se você tiver, eu não tô” [risos].

E finalizando a sua entrevista, ela desvela ainda os novos significados que vem atribuindo a esse momento existencial no qual está emergida:

eu fui no médico e ele falou que tem umas "bolsa" aqui que era da idade [risos], com começo de artrose no joelho, né? [...] eu saí de lá eu 'tava de táxi, eu vim coçando a cabeça: "ele chamou eu de velha" . Falei pro motorista, ele falou: “ah..., você é superior” e deu risada.

A seguir, passaremos à compreensão e interpretação da temporalidade masculina frente à vivência da infidelidade da parceria e da re-significação da relação amorosa. 


\subsection{O temporalizar da infidelidade amorosa pelas vozes masculinas.}

“O que será que me dá que me bole por dentro, será que me dá o que me sobe às faces e me faz corar e que me salta aos olhos a me atraiçoar e que me aperta o peito e me faz confessar o que não tem mais jeito de dissimular o que nem é direito ninguém recusar e que me faz mendigo, me faz suplicar o que não tem medida, nem nunca terá o que não tem remédio, nem nunca terá o que não tem receita.

O que será que será que dá dentro da gente e não devia que desacata a gente, que é revelia que é feito uma aguardente que não sacia

que é feito estar doente de uma folia que nem dez mandamentos vão conciliar nem todos os ungüentos vão aliviar em todos os quebrantos, toda alquimia que nem, todos os santos, será que será o que não tem descanso, nem nunca terá o que não tem cansaço, nem nunca terá o que não tem limite. O que será que me dá que me queima por dentro, será que me dá que me perturba o sono, será que me dá que todos os tremores me vêm agitar que todos os ardores me vêm atiçar que todos os suores me vêm encharcar que todos os meus órgãos estão a clamar e uma aflição medonha me faz implorar o que não tem vergonha, nem nunca terá o que não tem governo, nem nunca terá, o que não tem juízo”.

Chico Buarque. 


\section{Romeu}

Entrevista realizada em 19 de fevereiro de 2005.

Romeu é solteiro, tem 34 anos e sua ex-parceira tem 32. Romeu é católico e Julia, sua ex-parceira, é espírita. Ele possui ensino superior completo e ela ensino médio completo. O nível econômico de Romeu corresponde à classe A2. Ele relata que entre ele e Julia havia uma grande distância em relação ao nível econômico e sócio-cultural, sendo ela proveniente de uma família com poucos recursos financeiros. Ao iniciarem o namoro, Julia era empregada doméstica, encarregada de cuidar dos afazeres do dia-a-dia e das crianças de uma família que a tratava como “filha”. Quase no término relacionamento, ela trabalhou no comércio da cidade em que morava. Romeu e Julia se conheceram quando ele tinha 18 anos de idade e ela 16, tiveram um namoro de aproximadamente 03 anos, permeado pelo ciúme e por diversas agressões físicas e verbais. Terminaram o relacionamento há 3 anos. Romeu relata que a certeza de que Julia lhe era infiel tornou a relação afetiva do casal "fragilizada" e que ele passou a se relacionar com ela somente com o objetivo de terem relações sexuais, até se distanciarem definitivamente, em virtude da ausência de afetividade e de companheirismo entre os dois.

Romeu relata que já havia tido outras namoradas na adolescência antes de conhecer Julia. Fala também sobre a relação afetiva e sexual na juventude, mantida na parceria com Julia.

Ao iniciar a sua descrição, ele conta que os dois se conheceram de "modo inesperado":

eu tava com um amigo passando numa avenida, e duas moças bonitas subindo essa avenida... eu parei pra conhecê-las e tal, uma já namorava, não 
deu muita bola, tal, a outra foi mais simpática, vamos dizer assim. E essa moça simpática eu comecei a me relacionar com ela, saímos aquele dia mesmo, se eu não me engano, fomos numa boate e depois de um certo tempo começamos a ter relação sexual, não lembro se alguns meses, semanas, eu não me recordo.

Percebemos que o encontro entre Romeu e Julia foi permeado pelos laços do amor romântico, marcado pela atração imediata e pela subtaneidade, visto que iniciaram o relacionamento no dia em que se viram pela primeira vez.

Embora se fundamentasse em valores pertinentes ao ideal do amor romântico, o namoro que se segue expressa uma permissibilidade em relação à vivência da sexualidade antes do casamento, uma liberdade sexual que se iniciou com a emancipação da mulher desde 1960 e que demarca na contemporaneidade muitos relacionamentos amorosos. Mais que isto, o exercício da sexualidade é atualmente vivenciado também pelos relacionamentos relâmpagos que não prezam pela afetividade, mas pelo prazer momentâneo e ininterrupto.

Prosseguindo em sua descrição, Romeu relata que o sexo era “o pilar” do relacionamento do casal e em vários momentos de sua entrevista enfatiza que a relação era permeada por “sexo, sexo, sexo... muitas incertezas”.

Desvela que no início do seu namoro com Julia não sabia “reconhecer” se ela lhe era ou não infiel, que Julia lhe contava muitas mentiras sobre sua história de vida pessoal e familiar e nunca soube definir seus sentimentos em relação a ela: "sempre gostei, só que não sabia se era amor, se era paixão, se era tesão”.

Embora revele que a vivência da sexualidade na parceria era muito prazerosa, Romeu ressalta o fracasso do casal perante a sociedade, dizendo que havia no namoro muito ciúme, brigas e escândalos públicos, que o fizeram, em sua visão, perder a motivação pelo relacionamento, como percebemos no relato abaixo: 
A gente sempre teve uma relação sexual muito gostosa, muito fogosa, só de chegar perto já o fogo já acendia..., coisa que nunca mais veio acontecer comigo. Talvez acho que pela idade, com dezoito anos a gente é mais fogoso, moleque ainda novo..., então, a gente tinha uma química muito forte, só dela chegar perto eu me excitava e ambos sempre partia pra aquela "rapidinha". Depois que a gente vai tendo esses desgostos da vida-a-dois eu fui perdendo o tesão e me valorizando mais... e me afastando.

Prosseguindo em sua descrição, Romeu relata como se sentiu quando soube que Julia lhe era infiel, revelando sobre o modo de vivenciar o amor, a dor e o luto desencadeados pela infidelidade da parceira.

O colaborador relata um momento em que, ao chegar à casa da namorada, presenciara um encontro dela com um ex-namorado que lhe pediu para manter em segredo esse acontecimento por ser noivo de outra moça. Romeu revela "ter se sentido traído”, nesse momento: “Depois que houve essa suposta traição, que tava na dúvida, mas é muito evidente mesmo assim, eu... terminamos o namoro de uma vez e tal, partí pra outra, ela veio atrás e pediu pra voltar” e revela ainda que com o passar do tempo ele foi perdendo o interesse por ela, "tanto afetivo como sexual, é óbvio”.

Romeu continua dizendo que:

ninguém chegava pra mim e falava: "pô, termina com essa moça porque aconteceu isso, isso, isso [refere-se à infidelidade], eu te provo por A mais B”. Não, todo mundo deixava no ar, minha cabeça ficava confusa, eu brigava com a menina, a menina negava e era um saco, cê entendeu? E isso deixava a gente completamente pirado, eu achava que eu tava ficando doido, depois disso não, depois disso eu namorei muita moça. Graças a Deus eu percebi que a desequilibrada da situação era ela.

Percebemos com esse relato que Romeu se sente confuso e com dúvidas sobre a sua própria sanidade mental, pois não conseguia compreender a sua angústia e nem se Julia lhe era mesmo infiel e porque procedia dessa maneira.

Ao ser indagado sobre como se sentia nessas situações, Romeu desvela que sentia muita "raiva, insegurança e incerteza”. 
Às vezes eu tava acompanhado também [quando a via com outro homem], às vezes pairava uma incerteza, uma insegurança, um sentimento de: "sou ou não sou chifrudo?”. “Não sei...”. Eu bebia umas a mais, depois procurava ela ou ela me procurava e voltava tudo bacana e rolava tudo de novo, porque era aquela incerteza, né? Quem partiu primeiro pra isso eu não sei, fica difícil, tá? Mas eu acho que perdemos o respeito desde que um levantou a mão pro outro... eu como não tenho esse costume, nunca tive isso, eu acredito que ela levantou pela primeira vez, eu não me recordo, ela que levantou e acertou e levou outra, a partir daí perdemos o respeito.

Vemos acima que Romeu responsabiliza o teor alcoólico contido na bebida que ingeria por suas atitudes e pelo seu comportamento agressivo.

Prosseguindo, ele relata que quando brigavam:

eu saia sozinho ou saia acompanhado de outra mulher e cruzei várias vezes com ela acompanhada de outro homem, nem sempre essa mulher que tava comigo eu tinha alguma amizade colorida, mas eu já cheguei a vê-la beijando e tal e... várias vezes essa falta de respeito. Ou ela ir embora com alguém de um restaurante, de uma boate, e isso me deixava...

Percebemos com esse discurso que, assim como Julia, Romeu também era infiel e que ele não consegue nominar seus sentimentos frente à infidelidade dela.

As descrições de Romeu remetem a uma dramática história de ciúme e de violência que não se restringe somente a uma agressão do homem para com a mulher, mas a uma agressão mútua entre os gêneros, tal como se apresentou nas vivências descritas por Stela.

Na ótica de Nasio (1997), o ciúme é “um afeto em que se mistura a dor de ter perdido o amor do amado, a integridade da minha imagem narcísica, o ódio contra o meu rival e, enfim, as acusações que eu me faço por não ter sabido conservar o meu lugar”.

É, pois, uma variante da dor psíquica, uma reação à suposta perda do amor que o amado nos dedicava e que desvia para um rival. 
Sendo assim, para compreendermos a dor vivenciada por Romeu, temos que nos remeter a uma dimensão existencial do fenômeno que denominamos: Ciúme e violência: a tragédia amorosa.

O colaborador relata que o sentimento de ciúme gerava muitas discussões e agressões físicas e psíquicas que não atingiam somente o casal, mas envolviam a rede de contatos sociais deste.

Relata que esse comportamento fez com que seus amigos se afastassem do casal e revela no discurso a seguir que as agressões e o ciúme eram expressos por ambos: “às vezes a gente ia pra boate, discutia na frente dos outros, já joguei mesa pro alto, copo de cerveja no chão, já comprei briga, ela já pegou menina pelo cabelo, já quebrou copo de cerveja na cabeça de menina”.

Ele continua relatando que:

Uma vez uma vez ela fez uma pirraça comigo, que ela era muito pirracenta, e a gente tava comendo um lanche e eu esfreguei o lanche na cara dela, quente, do jeito que tava, com ovo, tudo. Depois uma vez eu torci o braço dela e quebrou, aí eu levei ela no hospital e falei: “cê você falar que foi por ciúme, queimar meu filme, vai ficar pior...”. Eu nunca tinha chegado a esse ponto [de agredir o outro fisicamente], entendeu? A gente escuta isso de pessoas de baixo nível, o pessoal que não tem estudo, que não tem nível social, que bebe pinga no boteco da esquina, chega em casa e bate na mulher. Eu também me sentia muito mal com a situação, e quando essa menina me levava a esse ponto eu via que eu não era o mesmo.

Segundo a perspectiva de Caruso (1986, p.149), a separação para um casal denuncia fatalmente a infelicidade do homem, que deixa claro que existem, na relação amorosa concreta, elementos estranhos e contrários ao amor, como o ódio, mesmo que não esteja presente de forma inteiramente consciente.

Em relação às vivências relatadas pelo colaborador, não tratamos aqui de uma separação física, mas sim de uma ruptura simbólica que dilacera o $e u$, pois uma representação psíquica idealizada não é suprida. Romeu tende a controlar a parceira e 
quando não consegue, reage agressivamente; é como se perdesse algo que desejasse e por isso, agride.

Na perspectiva psicanalítica, se de um lado a morte e o ódio são fenômenos primários, de outro, eles se originam da opressão e da ameaça ao amor, sendo o princípio de desempenho o responsável por transformar o amante em agente perturbador (Caruso, 1986).

Prosseguindo, Romeu diz:

\begin{abstract}
Achava que eu surtava, eu surtava, então eu pensava: “quem sou eu?”, “o quê tá acontecendo?”, “é um demônio que tá no meu corpo, ou o quê?”. Eu acho que não, eu acho que tudo é provocado na vida, seja o ciúme, seja o amor, seja o carinho. Onde há carinho, você dá carinho, se você dá carinho e não recebe carinho, vai embora. Onde tem o amor, onde tem Deus no coração, tem a paz, vai tudo tranqüilo. Onde tá um ambiente de desconforto e falta de respeito, não tem amor, entendeu? Tem tesão, tem sexo, tem... qualquer coisa, menos amor.
\end{abstract}

Podemos compreender que ao perder suas próprias referências e se comportar agressivamente na relação amorosa, tendendo a culpar a parceira pela falta de amor e de carinho, o colaborador percebe essa relação como um agente perturbador. Sendo assim, o colaborador demonstra se manter o tempo todo persecutório e alerta, manifestando um modo preocupado de ser.

Embora o colaborador tenha relatado no início de sua descrição que tivera relações sexuais com Julia desde o início do namoro, percebemos nesse último relato que ele realiza uma dissociação entre o amor e o sexo, no qual o sexo representa um elemento pejorativo.

Romeu diz ainda que, quando as agressões ocorriam, os amigos diziam: "larga dessa menina, que essa menina eh::: não dá pra comparação de uma garrafa de pinga com rótulo de uísque escocês, se afasta dessa menina que ela é bonita, ela é atraente, 
mas ela não presta”. Neste momento, as qualidades das quais Julia dispunha não correspondiam a um ideal de eu comum aos amigos de Romeu.

Na visão de Caruso (1986), quando a imagem do amado é “introjetada” ou devorada pelo eu, o devorado também exerce uma apropriação tão completa do eu que o submete a mobilizar "componentes orais" e "sádico-anais"; de modo que a escolha feita se torna tão ambivalente que não pode estar dissociada do ódio. Sendo assim, a qualquer fracasso, o eu reage com a exacerbação dos mecanismos de incorporação, de modo que o próprio amor pode tornar-se agressivo, tal como podemos perceber nas vivências relatadas pelo colaborador.

Desse modo, suas vivências denunciam o caráter compulsivo, descontrolado e persecutório que constituem o ciúme, na visão de Kehl (2004).

Na perspectiva de Gikovate (2006), o ciúme surge sempre que existe um risco de perda da pessoa amada, como pode surgir também naquelas pessoas que tem medo de perder regalias, ou ainda, surgir por temor à solidão. Nessa ótica, as pessoas que com mais freqüência sentem ciúme não são, necessariamente, as pessoas que mais intensamente amam, mas as que mais temem perder o amado eleito ou ainda um objeto que lhe é caro.

Nesse sentido, o ciúme corresponde ao medo de lidar com as frustrações, de lidar com o sofrimento psíquico e também com as perdas, de todo e qualquer tipo. O ciúme ainda se opõe à liberdade individual, pois é um sentimento que nos leva a agir na tentativa de limitar os direitos da pessoa à qual estamos ligados “em nome do amor”. O autor afirma ainda que se sentir traído, ofendido, desrespeitado em algum direito, ainda que vago e indefinido, leva a uma reação de raiva e desejo imediato de vingança, uma ânsia de retaliação que varia desde "pagar na mesma moeda” para provocar o ciúme 
também no outro, bem como agredir violentamente, o que podemos notar nos comportamentos relatados por Romeu.

Gikovate (2006), diz que o ciúme se correlaciona com a humilhação narcísica, como "uma ferida na vaidade", quando o sujeito tem a sensação de ser tratado com descaso e inferioridade, de ser “trocado” por alguém mais interessante.

Romeu prossegue descrevendo uma situação em que desconfiou que o patrão de Julia pudesse estar interessado nela por ter lhe dado uma "lata de cerveja” após o expediente e de fato, “ela o troca”, como percebemos no relato abaixo:

Liguei pro cara, tirei satisfação, dei uma de "corno bravo", que tem o "corno manso" e o "corno bravo", dei uma de corno bravo, foi péssimo né?, discuti com o cara, né?, depois de um tempo que nós brigamos ela saiu com o cara, ou seja, tá certo, isso eu presenciei, tá?, puseram até aliança, ela fazia questão de passar na minha frente com o cara, ela fazia questão, muitas vezes mandava as amigas me ligar prá, prá me cantar ou prá me humilhar de alguma forma.

Mesmo tendo sido "trocado" por outro homem, Romeu, sem ainda elaborar o "luto,” percebe a existência de Julia como um objeto perseguidor e diz: "Eu me sentia mal, pensava às vezes de fugir, de passar longe, ela ficava perto [...] fazia questão de passar em frente, mostrar, provocar, extremamente infeliz da parte dela”.

Romeu conta que, mesmo noiva desse rapaz, Julia procurava por ele e eles mantinham encontros "às escondidas”. Ele relata que os amigos lhe diziam: “olha lá fulana, ‘tá com outro” e ele diz: “mas o que eu ia fazer? Eu vou lá brigar? Ela tá porque qué”, e revela que manter uma relação dessa forma "era nojento. Aí eu pegando nojo dela, aí depois que ela colocou aliança com esse sujeito [...] e acabou casando com esse cara. Então, quer dizer... ela não presta”.

Parece-nos que quando Julia opta a ficar noiva de outro homem, Romeu parece compreender que perdeu "as suas chances” em estar com a garota e deixa de brigar com 
ela e de investir na relação amorosa. Ele muda a sua posição de eleito amado para amante, porém, desvaloriza Julia enquanto mulher.

Na perspectiva de Gikovate (2006, p.129), o ciúme está relacionado ao papel que uma pessoa desempenha na vida de outra, de modo que o amante "tem ciúme de todas as outras pessoas menos do cônjuge da amada, pois ele tem mais 'direitos' sobre ela. [...] Ao mesmo tempo, deixará de se sentir traído, humilhado e passará a se ver como o traidor. Igualmente, o amante traidor agora se sente traído”. Essa citação expressa justamente os sentimentos e como Romeu passa a compreender a situação vivenciada.

Relata que ia ao apartamento de Julia de vez em quando, de madrugada, quando: “eu tava na rua, no barzinho, numa boate, eu tomava todas e aparecia na casa dela e ela abria... a gente ia lá... deitava, dormia, às vezes transava, às vezes transava, às vezes dormia e transava no dia seguinte, às vezes não transava, eu ia pra isso [ter relação sexual]. Até um dia ela encheu o saco e também correu comigo de lá” e desvela o modo de se relacionar com Julia no término do namoro, sendo seu principal objetivo satisfazer-se sexualmente.

Descreve ainda uma situação importante que aconteceu e que o fez desistir de encontrar-se com Julia:

Um dia em que eu dormi lá e eu peguei uma receita do criado mudo e 'tava escrito pra acender duas velas, não sei pra..., três velas, não sei lá pra quê, e eu falei: “isso aqui é macumba?” e eu fui embora. Isso foi um dos pontos que me assustou. Eu sou muito religioso, muito devoto de Deus e a pessoa que procura essas coisas alternativas pra mim ela tá por fora, e eu não quero... e a gente sabe que Deus tem muita força e a gente 'tando do lado Dele a gente se torna mais forte. Mas o maligno também tem força, então é bom a gente não estar perto de pessoas que mexe com... que acende a vela pro vermelho. Eu sou radical, quando eu tomo uma decisão eu saio de perto. [...] Fui conhecendo aos poucos que realmente não prestava, tudo aquilo que pairava dúvidas na minha cabeça veio tudo à tona. “ah... essa menina não presta, ah, essa menina é uma pinga com rótulo de uísque...”, eu fui reconhecendo, aos poucos. 
Seu discurso revela as desilusões da ruptura da imagem do outro idealizado e, em conseqüência da quebra de seu próprio espelho narcísico, o amado eleito aparece aqui como um objeto desconhecido tão diferente do idealizado que leva o colaborador a compreender que Julia não era o que ele desejava.

Passaremos então à dimensão existencial do fenômeno que se refere à resignificação do relacionamento amoroso na perspectiva de Romeu.

Na visão de Nasio (1997), a humilhação narcísica é um ferimento na imagem que alimento de mim mesmo, ou seja, na representação psíquica que tenho de mim mesmo, a qual para o colaborador se torna a de um eu ferido com a traição e com o “abandono”.

Depois de tanto ciúme, desavenças e agressões, o colaborador parece pouco a pouco desinvestir-se do objeto amado e atribui novos significados a relação que passa a assumir com Julia, dizendo que se encontrava com ela com o intuito somente de obter com ela satisfação sexual, como demonstra a seguir: "Eu ia por sexo. A gente se relacionava muito bem, tinha uma química muito boa, que eu me lembre hoje era pura e simplesmente por... por... por química.”

Na visão psicanalítica, a escolha objetal narcísica projeta no outro aquilo que eu gostaria que ele fosse. Depois de vivenciar tantos desencantos no relacionamento, Romeu compreende que Julia não atendia às exigências de seu ideal do eu, e conclui o "luto”: “Talvez as pessoas não tinham realmente que me falar, eu não enxergava, ou sei lá... não queira enxergar. A vontade de ficar com ela, de permanecer com ela, falava mais alto. Eu falava assim: “esse cara tá é com inveja, ele quer é transar com a minha namorada”, e eu não largava de jeito nenhum, não largava por nada”. Prosseguindo, ele se recorda da última vez em que esteve com Julia e é capaz de assumir uma decisão de não querer mais estar com ela: 
foi quando ela tava noiva do cara que atualmente ela casou e teve dois filhos, e ela saiu comigo, nesse dia me deu nojo totalmente, e eu lembro que foi a última vez que eu a vi, não, não, que eu cheguei a sair com ela. Depois eu encontrei com ela algumas vezes fazendo promoção em SIN [nome de lugar], essas coisas, ela até me cantou prá tomar um choppinho pra relaxar, eu falei: - "não, você é casada”, “não, mas só um choppinho”, não sei o que lá”, aí eu nunca fui não.

Romeu relata que a experiência de ter se relacionado com Julia foi "bom demais, foi tanta porrada, foi tão desgastante que eu cresci e amadureci” e diz que teve vários outros namoros longos e breves depois de ter namorado Julia, que em dois deles quase se casou, mas revela que "tem medo de se casar", de assumir as co-responsabilidades de uma união comum. Ele diz que: “a mulher hoje em dia tá com a cabeça vazia, muito fraca e eu prefiro bagunçar do que levar um relacionamento a sério, pra não me machucar depois ou machucar a pessoa”.

Desvela ainda o seu modo de compreender as relações afetivas e sexuais na contemporaneidade:

O homem busca carnalmente. O homem, ele pode... ele ama, às vezes, às vezes não, ele ama uma mulher, ele ama uma, uma, uma, uma [ênfase]. Eu tenho quase que 99.8 'prá não falar, não falar 99.9 e certeza que o homem ama uma mulher, ele pode sair com dez, ele ama uma. No meu caso..., não me gabando: - "Oh, eu sou diferente"-, mas eu converso com amigos e sinto "ressaca moral” se eu "pulo a cerca”, enquanto que os outro não ‘tão nem aí.

Assim, ao falar dos seus semelhantes Romeu fala de si mesmo e depois se contradiz, não sabendo ao certo que posturas assumir frente à (in)fidelidade e referindose a uma característica que em sua percepção deve ser atribuída ao gênero masculino: a necessidade física de satisfazer-se sexualmente. Seu relato revela, desse modo, como os padrões morais se implicam na constituição de nossas subjetividades, sendo transmitidos ao longo dos anos. 
Passaremos agora à compreensão e interpretação da descrição da temporalidade de Aquiles frente ao fenômeno da infidelidade da parceira e da re-significação da relação amorosa.

\section{Aquiles}

Entrevista realizada em 26 de Fevereiro de 2005.

Aquiles tem 31 anos, é noivo de uma garota que namora há 04 anos, e a sua exnamorada, Fernanda, sobre a qual nos concedeu o seu depoimento, tem 29 anos. Aquiles é católico e Fernanda é batista. Ele possui curso de pós-graduação e ela possui curso de pós-graduação incompleto, sendo que ambos trabalham na área da educação. O nível econômico de Aquiles corresponde à classe A2. Aquiles teve com Fernanda um relacionamento de 03 anos e quando começaram a namorar, eles tinham 27 e 25 anos de idade respectivamente. Relata que vivenciara com ela um relacionamento de reciprocidade e de intimidade afetiva, mas que após um ano e meio de namoro soube que ela lhe era infiel, o que promoveu o seu desinvestimento da relação amorosa, fazendo da relação um motivo para satisfazer-se sexualmente, até o momento em que decidiu não mais se encontrar com ela.

Em sua descrição, Aquiles evidencia sua relação afetiva e sexual antes da vivência da infidelidade amorosa da parceira. 
Passaremos agora à compreensão e interpretação da descrição da temporalidade de Aquiles frente ao fenômeno da infidelidade da parceira e da re-significação da relação amorosa.

\section{Aquiles}

Entrevista realizada em 26 de Fevereiro de 2005.

Aquiles tem 31 anos, é noivo de uma garota que namora há 04 anos, e a sua exnamorada, Fernanda, sobre a qual nos concedeu o seu depoimento, tem 29 anos. Aquiles é católico e Fernanda é batista. Ele possui curso de pós-graduação e ela possui curso de pósgraduação incompleto, sendo que ambos trabalham na área da educação. O nível econômico de Aquiles corresponde à classe A2. Aquiles teve com Fernanda um relacionamento de 03 anos e quando começaram a namorar, eles tinham 27 e 25 anos de idade respectivamente. Relata que vivenciara com ela um relacionamento de reciprocidade e de intimidade afetiva, mas que após um ano e meio de namoro soube que ela lhe era infiel, o que promoveu o seu desinvestimento da relação amorosa, fazendo da relação um motivo para satisfazer-se sexualmente, até o momento em que decidiu não mais se encontrar com ela.

Em sua descrição, Aquiles evidencia sua relação afetiva e sexual antes da vivência da infidelidade amorosa da parceira. 
Ao iniciar o seu discurso, Aquiles relata sobre a vivência do relacionamento amoroso do casal:

Bom... o relacionamento tanto do ponto de vista afetivo como sexual, né?, sempre foi bom, né?, mesmo após eu perceber a infidelidade dela, a parte sexual se manteve boa, eu acho que era o que mais nos unia assim, né?, que realmente bem vivido, uma coisa bem legal. [...] a parte afetiva, ela... ela foi crescendo, foi uma progressão, porque a gente acaba, né?, aprendendo a gostar da pessoa, a conhecer ela melhor, né?, e... a gente chega ao ponto até de amar essa pessoa. Então no comecinho, é claro, que começa morno, depois a gente vai se descobrindo, se conhecendo, tendo aquela reciprocidade, aquela entrega, né?, aquela cumplicidade, então isso cresce e... atingiu o ápice, até eu realmente começar a perceber a infidelidade dela.

Ao relatar sobre o relacionamento amoroso, Aquiles expressa uma forma de se relacionar semelhante àquela exposta por Torres (2002), o “amor construção”, no qual a cumplicidade, o envolvimento e a reciprocidade são construídos no dia-a-dia, no encontro autêntico entre os parceiros conjugais.

Aquiles relata ainda como percebia em Fernanda, na perspectiva psicanalítica, o seu ideal do eu:

uma pessoa amável, uma pessoa dócil, aliás ela sempre continuou, mesmo após a... suposta infidelidade, que eu nunca pude comprovar com os meus próprios olhos, mas eu sempre tive evidências muito fortes disso, mas... ela continuou da mesma forma, e eu também continuei vendo ela da mesma forma, mas com algumas ressalvas, isso que eu quero dizer, né?

O ideal do eu corresponde à instancia psíquica que, pautada nos valores morais e éticas exigidos pelo superego, escolhe aqueles que constituem um ideal para o sujeito. Desse modo, características como “amabilidade” e “docilidade” pareciam corresponder, 
dentre outras características, à formação da imagem de mulher ideal, que habita as fantasias e aspirações de Aquiles.

O termo “amabilidade” refere-se, segundo Borba (2004), à delicadeza, afabilidade e gentileza e o termo “docilidade” diz respeito à maleabilidade, sujeição, e à própria amabilidade e delicadeza, qualidades preferidas nas mulheres desde a submissão patriarcal.

O discurso de Aquiles revela que a manutenção e continuidade do relacionamento só puderam perdurar enquanto o ideal do eu a respeito de Fernanda pudesse ser mantido, ou seja, enquanto ele ainda a admirasse e encontrasse nela sossego para suas aspirações.

Continuando seu depoimento, Aquiles revela ainda outras características que encontra em Fernanda:

Ela era uma pessoa, com eu disse, muito carinhosa, tinha muita afinidade assim... inclusive do ponto de vista religioso, aparentemente, pelo menos, né?, e assim... pessoa carinhosa, pessoa muito amiga, entendeu? eh... muito... inteligente, muito sensível com as minhas causas, com as minhas idéias, e com as dela também, muitas coisas em comum. É... tinha o ponto de vista sexual, era muito forte, então, a gente se dava muito bem, então isso, fazia com que a gente né?, eh... se desse bem sempre, né?, enfim... [...] nesse ponto [sexualidade] foi... foi muito bom, né? eu não tenho do que reclamar, acredito que nem ela, sempre fluiu muito bem, de maneira natural, de maneira bem... bem plena mesmo.

Assim, como também desvelou Romeu, Aquiles encontra na religião um pilar importante para as afinidades do casal. No entanto, relata uma vivência bem diferente daquela relatada por Romeu. Aquiles encontra por meio da religião, dentre outros pontos, suas semelhanças com Fernanda, o seu pertencimento a um ethos comum, a um modo sintonizado de existir com o outro, seu semelhante.

Na perspectiva psicanalítica, a “projeção” é um modo de defesa primária no qual o sujeito projeta em um outro sujeito ou objeto os desejos que provém dele, atribuindo-lhes 
uma alteridade que lhe é externa. O mecanismo de “introjeção” se refere ao processo no qual o sujeito introduz, fantasmaticamente, objetos de fora para o interior de sua esfera de interesse. Podemos dizer que, em simetria, esses dois mecanismos produzem um ensimesmamento auto-erótico, no qual Aquiles encontra na figura da amada "quase” tudo aquilo que deseja, ou seja, realiza uma “projeção”, como desvela seu último relato. (Roudinesco \& Plon, 1998).

Assim como foi visto nas descrições de Verônica e Flor de Liz, a vivência de Aquiles também nos mostra que, embora a preocupação e a angústia sejam básicas em nossa existência, somos capazes de vivenciar momentos de sintonias e tranqüilidades, quando estamos agradavelmente envolvidos com alguém ou em algo (Forghieri, 2001).

Na perspectiva fenomenológica “quando nos encontramos com alguém que compreendemos, e de quem gostamos e sentimos que nos corresponde: nossos olhares, nossas vozes, nossos gestos fundem-se numa totalidade e sentimo-nos como se fôssemos uma única pessoa” (FORGHIERI, 2001, p.38). As palavras desta autora tornam possível a compreensão de que a visão psicanalítica, embora sendo outra perspectiva teórica, trata certa dimensão fenomenal de modo comum, portanto o que estamos dizendo é que o sujeito interpretado por uma perspectiva ou por outra é visto enquanto uma “unidade” com o outro, o fundir-se com, a união entre o interno e o externo, o eu e o outro.

Embora Aquiles tenha deixado claro em seu depoimento um modo sintonizado de existir com o outro na relação amorosa, ele também desvela os desencantamentos que teve no namoro e a relação destes com a infidelidade amorosa de Fernanda.

O fato assim: de eu às vezes falar: “olha, não vai dar pra mim estar com você em tal festa, em tal lugar...”, e ela não se importar nem um pouco em eu não estar indo, né?, ou a gente tá de repente em algum lugar e o pessoal querer ir pra outra balada ainda e eu ter que ir dormir mais cedo por causa do meu trabalho, e a 
gente já tinha curtido bastante e ela querer, né?, sair mais ainda né?, ou seja, não se importando se eu ia 'tá junto ou não ia, essas coisas me deixavam triste, eh... falta mesmo assim de... de respeito, nem... nesse ponto. Qualquer pessoa que tenha que ser $100 \%$ você... eu acho que a gente tem nossa individualidade, a nossa liberdade, mas quando namora isso muda um pouco, né?, não tem mais como você levar da mesma forma como se você tivesse sozinho, né?, eh ... e eu era ciente disso, eu era bem diferente, né?, eu era assim... um namorado mesmo, mas eu não via isso nela.

Com o passar do tempo, Aquiles percebia a falta de cumplicidade, intimidade afetiva e reciprocidade na relação amorosa, por parte de Fernanda. A diferenciação entre objeto e eu, necessária para que não ocorresse o aniquilamento do eu e resultasse na vivência de um relacionamento autêntico e maduro, existe, entretanto, Aquiles percebe que a liberdade vivenciada no relacionamento corresponde a mais que isso, a uma falta de interesse e respeito para com ele por parte da parceira.

Aquiles diz que Fernanda gostava muito de sair sem a sua companhia, durante o namoro: “...gostava de ficar comigo também, mas eu percebia que ela gostava de ficar mais sozinha né?, de estar com os amigos e amigas, embora ela gostasse muito de mim”.

muitas vezes eu não podia 'tá junto ... ela não se importava nem um pouco de fica né?, ela ia mesmo, é roupas assim... muito sensuais, decotadas né?, saia curta, eh... bebia bastante, dançava exageradamente, dançava provocante, entendeu? ia embora com outras pessoas, que muitas vezes eu nem conhecia, enfim, né? uma série de coisas. [...] tinha algumas atitudes vulgares [...] através das roupas assim, da risada, da forma de sentar, cê entendeu? Estar numa festa assim... beber... às vezes, sabe?, ficava se insinuando pra todo mundo.

Além de gostar de sair sem a companhia de Aquiles, o comportamento social de Fernanda não era admirado pelo namorado que, ao desencantar-se com a relação amorosa, inicia um processo de aceitação da realidade, de desidealização do objeto amado. 
Prosseguindo em sua descrição, Aquiles revela uma outra dimensão existencial do fenômeno: o amor e a dor vividos a partir da infidelidade de Fernanda, e o luto empreendido nesse processo.

Aquiles destaca que as pessoas, os amigos, lhe contavam que viam Fernanda acompanhada de outros homens, saindo de alguma festa e até no dia seguinte, pela manhã. Entretanto, relata que “se sentia muito mal”, mas “custava” a acreditar que essas informações eram verdadeiras:

embora o comportamento dela sempre for duvidoso mesmo, né?, não condizente com um namoro sério, né?, mas, quando a gente constata mesmo que 'tá muito evidente, que 'tá havendo mesmo assim, uma... uma "pisada na bola" [infidelidade], 'né?, a gente fica muito chateado, eh ... muito "puto”, como se diz, né?, no vocabulário vulgar, né?. Não, como assim... falar, já faz algum tempo já, né? que a gente..., um bom tempo que a gente largou aí, por volta de seis anos, mas é muito difícil, você fica com raiva, depois você fica assim... indignado, né?, por assim, foi muito mais entrega da minha parte do que da dela, quando você constata isso, né?, tudo o que você fez pra tá bem com aquela pessoa não foi recíproco da mesma maneira é... é muito difícil você assimilar isso e levar numa boa, né?

Aquiles se sente traído por ter se doado mais que Fernanda na relação e o eu custa a assimilar a realidade cruel, a que não corresponde mais ao ideal de eu.

foi difícil, foi complicado, né?, claro né?, porque você... se deparar com uma situação dessa [infidelidade], mesmo como eu disse, eu não ter visto assim in loco né?, de ter né? pessoalmente ter conferido isso, mas era tantas evidências, o comportamento dela, enfim, levava a ter certeza da infidelidade dela. Mas é difícil, é dolorido, porque... você deposita toda uma confiança, um sentimento, um amor, que nesse ponto já tava, né?, a tona né?, e... a fidelidade faz parte né?, de uma entrega, enfim né?, de um respeito, de uma amar mesmo, e aí quando acontece você... puxa, realmente é ruim, você conciliar, você querer continuar com a pessoa, gostando dela ainda né?, mas sabendo que ela pisou na bola. É muito difícil. 
Ao valorizar o amor, a confiança, a fidelidade e a entrega, Aquiles desvela suas expectativas acerca do amor, que estão implícitas no ideal romântico e que, ao trafegarem entre as subjetividades femininas e masculinas na atualidade, nem sempre são alcançadas.

Aquiles revela que após ter constado a infidelidade amorosa da parceira, acabou por ser infiel a ela também, movido por um sentimento de "vingança”. Diz ainda que foi muito “desagradável” não ser correspondido:

muitas vezes era constrangedor, era triste, né?, eu não queria [ser abandonado], né?, de repente porque ela, ela assim... ela demonstrava muito o sentimento, o amor, mas da forma dela, da maneira dela né?, então, assim, eu acreditava que ela gostava, que ela me amava, só que as atitudes dela não correspondiam a isso.

A maneira como Fernanda se comportava não condizia com o ideal do eu, de modo que Aquiles sentia-se confuso em relação à certeza de que a amada gostava dele.

Diz em seu relato que seus sentimentos eram:

de revolta às vezes, de raiva, né? sentimento assim... de eh ... indignação, essas coisas, né?, um pouco assim de ... pena dela por ela estar agindo assim [desinvestindo da relação e sendo infiel], de ver o que ela 'tava perdendo ou do que ela 'tava pondo a perder, né?, eu sempre me valorizei muito e... assim, sentimento assim... até sentimento de compaixão talvez né?, porque eu orava muito 'prá que Deus mudasse isso nela, tocasse o coração dela, que ela se transformasse, caísse na real né?, isso até acabou acontecendo, mas quando aconteceu, como eu disse agora a pouco, já era tarde né?. Não tinha mais vontade de ficar com ela, só de transar mesmo, mas... aquela afetuosidade [ênfase] toda, aquele amor, aquele carinho, aquele sentimento, não.

Aquiles relata que após um ano de namoro, quando os colegas passaram a lhe dizer que Fernanda lhe era infiel, que o sentimento, o carinho e o amor inicialmente continuaram presentes no relacionamento, embora de modo diferente, mas que a imagem que se tinha do outro é transformada: 
a parte afetiva ela abalou, ela abalou obviamente, o sentimento acaba ficando diferenciado após você saber, né?, eh... ou desconfiar que seja da infidelidade, sendo que até o primeiro ano por aí, que foi quando eu comecei a perceber a infidelidade, a parte afetiva sempre foi muito forte, muito boa também, igual a sexualidade, mas após a infidelidade, é claro que, a parte afetiva deu uma balançada, mas a sexualidade se manteve bem até o fim. [...] todo aquele respeito, aquele carinho, aquele amor mesmo, o amor... o amor se manteve, né?, é claro, é difícil, eh ..., mas muda, diminui. Um pouco assim..., eh ah... lógico, a confiança, né?, eh... você passa a não ver a pessoa mais com os mesmos olhos, né?, e isso influi na afetividade, não tenha dúvida, né?, acabou diminuindo um pouco. [...] não sei se eu posso explicar exatamente o quê que é que mudou, mas muda pô, você... sabe que a pessoa tinha 'prá você, né? que ela era de uma tal forma, a partir do momento que isso acontece, muda.

As desilusões da infidelidade, a ruptura do pacto do amor eterno, geram a ruptura do espelho narcísico e promove ainda mais a diferenciação entre o eu e o outro. A nova imagem do outro demora a ser assimilada pelo eu e, ao mesmo tempo, emerge uma nova imagem de si mesmo, o que recai sob o sentimento amoroso e fica difícil então, amar esse novo objeto, tão diferente do outrora idealizado.

Como já dissemos, a reação do eu contra a comoção desencadeada pela perda do outro se decompõe em dois movimentos: o desinvestimento, que é uma aspiração súbita de energia e o superinvestimento, que é a polarização de toda essa energia sobre uma única imagem psíquica (NASIO, 1997).

Ao tentar defender-se o eu superinveste pontualmente na única representação do amado que não existe mais, o que provoca um esgotamento do $e u$. O processo de luto, entretanto, segue um movimento inverso ao da reação defensiva do eu, isto é, o trabalho de luto é o desinvestimento progressivo dessa representação, até o amado perdido tornar-se novamente conciliável com o conjunto da rede das representações egóicas. 
Antes de vivenciar o processo de luto, compreendemos que o colaborador se mantém durante um bom tempo "negando" a possibilidade da parceira lhe ter sido infiel. Porém, quando diz perceber que ela era realmente infiel, o processo de desinvestimento da representação psíquica do amado eleito parece ocorrer de modo diferente daquele empreendido pelas mulheres, daquelas que cumpriram de fato o processo de luto. Na vivência relatada por Aquiles, a figura amada, ao provocar uma desilusão ao eu, isto é, ao ferir seu espelho narcísico passa a ser, com certa rapidez, desinvestida.

O colaborador parece, portanto, re-direcionar sua libido para um outro tipo de gratificação na relação, como se anteriormente à perda da mulher idealizada, ele já tivesse uma outra representação psíquica para vesti-la. Isto talvez se explique pelo processo sóciocultural no qual fomos inseridos, que dicotomizou a imagem da mulher como "mulher casta e fiel” e a "mulher sexuada".

Motivado pelo ideal cristão, restaria a Aquiles dirigir-lhe “compaixão”, e pedir a Deus aquilo que sua onipotência narcísica não era capaz de concretizar. Ao se referir à vivência da sexualidade em detrimento da afetividade, Aquiles desvela uma nova dimensão vivencial do fenômeno: os novos significados que ele atribui à relação amorosa e, com eles, o modo como passou a se relacionar com Fernanda, ou seja, ele desvela o processo de resignificação de seu relacionamento amoroso com a parceira, depois de ter vivido o momento de luto e ter comprovado a infidelidade dela.

Ao perceber que Fernanda não possui as qualidades para um namoro sério, Aquiles muda, então, a sua maneira de ser em relação a ela:

o que correu [a infidelidade da parceira], logo após um ano, um ano e pouquinho assim... que a gente tava namorando, que eu passei a... agir com alguma diferença, um pouco mais... não frio, mas um pouco mais na minha, não demonstrar mais tanto carinho, tanto afetuosidade, né?, eu tentei começar a 
assimilar isso, né?, de uma maneira mais, né?, calma, tranqüila possível, mas, porém, mudando a minha forma de agir com ela, né?, assim... não dando mais tanta..., não demonstrando tanta certeza talvez, da minha confiança.

Na perspectiva de Forghieri (2001), temos, como seres racionais, a necessidade de analisar a nossa vivência cotidiana imediata para conceituá-la e estabelecer relação entre nossas experiências.

Nessa perspectiva, agimos de acordo com o nosso modo de compreender as situações, e nossas ações somente serão eficientes se forem adequadas à realidade dos acontecimentos. Como sabemos, nem tudo pode ser apreensível, mas é inegável a capacidade do ser humano compreender, por processos conscientes, parte de sua existência cotidiana.

Acreditamos que nem sempre é possível termos um comportamento baseado numa percepção adequada de uma determinada situação, mas que é possível que isso ocorra na maior parte do tempo.

Segundo Forghieri (2001), muitas vezes estamos insatisfeitos e na correria de nossos afazeres, no nosso modo de temporalizar; não encontramos tempo para ter consciência dessa insatisfação e ainda fazer algo para melhorar “as coisas”, do mesmo modo em que, em outras situações em que tudo esta correndo bem, estamos tão absorvidos pela rotina que somente "reparamos”, somente temos consciência disso, quando algo desagradável acontece.

Isso acontece, porque, segundo Forghieri (2001, p. 40):

“quando as experiências agradáveis ou desagradáveis são pouco intensas costumamos concentrar a nossa atenção apenas nos afazeres quotidianos”, bem como quando elas nos absorvem de modo muito intenso, nos dificultam perceber, claramente "como estamos vivendo e nos sentindo no decorrer de nossa existência”. 
Os dizeres de Forghieri (2001), afirmam, em nosso modo de ver, que há coexistência entre os processos conscientes e inconscientes.

Desse modo, enfatizamos o destaque que os processos conscientes têm no trabalho de luto.

Segundo a perspectiva de Forghieri (2001), em muitas situações, por mais que o indivíduo se empenhe em encontrar segurança e tranqüilidade em seu existir, estes estados chegam a ser alcançados apenas por alguns instantes pré-reflexivos [ou podemos dizer, inconscientes], nos quais vivencia situações de plena e profunda sintonia em seu próprio existir, não tendo o mais leve conhecimento de suas razões.

Porém, o ser humano é capaz de refletir a respeito de sua vivência quotidiana, analisando-a, levantando hipóteses [que podem não se concretizar], e chegando a algumas conclusões a respeito de seu existir no mundo. Todas essas elaborações racionais vão fornecer, na ótica de Forghieri (2001), elementos constitutivos sobre a própria vida, o que lhe permite tentar explicá-la e até levá-lo a planejar ações em direção ao que pretende para o seu futuro.

O relato acima é uma demonstração do "modo racional de existir”, proposto por Forghieri (2001), do qual o sujeito se utiliza de uma elaboração intelectual acerca de suas experiências quotidianas imediatas, a fim de analisar uma determinada situação e possíveis ações atuais e/ou futuras.

Compreendemos, entretanto, que os processos conscientes e inconscientes que constituem nossas subjetividades, ocorrem simultaneamente e são ancorados aos modos sócio-culturais isto é, ao mundo humano e circundante, nos quais nos encontramos com nossos semelhantes e com "tudo" o que nos rodeia. 
Desse modo, a maneira intelectualizada da qual Aquiles toma consciência, percebe e reconhece o modo de ser de Fernanda e o leva a adotar uma postura condizente com a sua visão de mundo, que traz em seu cerne, uma constituição sócio-histórica.

Assim, pautado no padrão social que diferencia as psiques de homens e mulheres Aquiles afirma:

a gente enquanto homem, ainda mais nessa idade [26 anos], tem a sexualidade muito aflorada, os hormônios estão lá em cima, do ponto de vista biológico, eu acho que falou mais alto, então, era muito bom a parte sexual entre a gente. Então, eu procurei manter com a mesma intensidade, só que no finalzinho mesmo do namoro, eu... fazia, né? com ela, a gente transava, tudo, né?, mas eu não tinha o mesmo carinho, obviamente não tinha mais o mesmo respeito, e eu fazia mesmo 'prá me satisfazer, mais por prazer mesmo do porque... num, num tinha mais como manter como era no começo do namoro que era o sexo envolvido com o sentimento, com o amor né?, depois já passou a ser mais assim.

Esse discurso desvela a divisão entre os sentimentos: à mulher indigna, resta ao homem, a satisfação de suas volúpias. Fernanda, destituída da falta de intimidade amorosa de outrora, bem como da amabilidade e docilidade, presentes nas mulheres, passa a ser somente, um objeto de prazer sexual.

Tal racionalidade, ou "frieza”, como diz o colaborador, o qual os homens executam tão bem no relacionamento amoroso, principalmente quando eles não são correspondidos, talvez seja uma herança da masculinidade dos tempos de outrora, que nos dias atuais continuam a constituir as psiques masculinas.

Prosseguindo, Aquiles afirma que sua mudança de postura em relação a Fernanda, o fez "sentir-se melhor":

Eu acho que ela não fez por merecer eu continuar a ... a agir, né?, demonstrando o mesmo carinho e o mesmo respeito que eu tinha por ela. Então, obviamente eu mudei porque eu me senti melhor, agindo assim.... não era mais tão assim... eh... 
carinhoso, entendeu?, mais tão assim... confiado nela, né?, agir de uma forma um pouco mais... “na linha”, né?, eu não concordava com tudo né?, em alguns aspectos eu amadureci um pouco mais. Eu não concordava com algumas coisas que ela fazia, eu julgava que não 'tava certo ‘prá um namoro firme...

Fernanda, fora então desqualificada, não servindo na concepção de Aquiles, para um namoro firme, e ao ser indagado sobre a separação, Aquiles diz:

Ela achava que tava tudo certo, que não tinha nada a ver [as infidelidade de ambos], que o que importava era o sentimento que ela tinha por mim, entendeu? Sempre dava de uma forma uma desculpa assim, arrumava uma desculpa pra sair por cima. [...] acho que eu comecei a ... a... a tê-la só mais pra sexo, eu acho que ela percebeu isso e no final ela não teve muito o que fazer porque ela acabou assim... terminando gostando de mim, que eu sentia isso né?, mesmo se arrependendo de muita coisa, e eu terminei assim... bem [ênfase], né?, porque não sei se era porque eu tinha me vingado dela também, eu acho que... foi muito triste pra mim o que ela me fez né?, e eu de uma certa forma me senti bem porque ela mereceu, e o meu sentimento acabou e o dela eu acho que aumentou, foi aumentando, aumentando, mas ela não tinha mais o que fazer e eu também não.

Com base no relato de Aquiles, podemos afirmar uma diferença entre os gêneros em relação à perda do objeto amado, o que sem culpa, Aquiles parece elaborar muito bem.

Na descrição de Isolda falamos sobre a necessidade da presença amorosa contínua, ou seja, da importância da continuidade do desejo, bem como da atenção e do cuidado do parceiro em relação ao ser feminino (Alberoni, 1988 apud Bruns \& Pereira, 2001).

a parte sexual se manteve, até consegui, eu consegui separar bem, né?, o amor, o sentimento, enfim, a parte afetiva e o sexo. Mas a parte afetiva não tenha dúvida que mudou, tanto é que eu cheguei ao ponto de não gostar mais dela, se não tivesse tido alteração, isso [não gostar mais da parceira] não, não tinha ocorrido, né?

Aquiles parece se comportar com uma regra machista, aprendida: “amor e sexo não precisam andar necessariamente juntos”. 
Ao se referir aos encontros sexuais, Aquiles diz sobre seu comportamento no período em que já havia terminado o namoro:

eu já tinha minha vida, saía com quem eu quisesse e ela não sei, mas eu fiquei sabendo também, através de pessoas que moravam junto com ela, amigas muito próximas, né?, que assim: ... ela tava triste, que ela chorava muito, né?, nesse meio tempo, meio que arrependida 'prá valer mesmo, mas aí já era tarde, acho que ela teve a oportunidade dela, não é?, de ter revertido isso enquanto a gente tava junto, né? e não fez. Aí o meu sentimento, assim, acabou a parte afetiva, né?, acabou, só continuei me encontrando com ela porque, como eu disse, a sexualidade era boa, esse era o ponto forte, né?, do relacionamento, fora isso, né?, não tinha mais nada.

O colaborador relata que Fernanda teve que mudar de cidade e que como se encontravam “apenas para fazer sexo, mesmo que de vez em quando”, a relação terminou nessa ocasião. Ao mudar de cidade Fernanda afastou-se definitivamente de Aquiles, porém, ele afirma ainda que "mesmo se ela tivesse ficado por aqui, acho que... mesmo esses encontros sexuais, vamos dizer assim, ia, ia... acabar por..., por, por terminar e acabando mesmo, né?

E, desse modo, o eu narcísico conforma-se e o sentimento causado pelo trauma pulsional é findo.

Passaremos, a seguir, à compreensão e interpretação da descrição da temporalidade de Ulisses, frente ao fenômeno da infidelidade e da re-significação do relacionamento amoroso. 


\section{Ulisses}

Entrevista realizada em 27 de Fevereiro de 2005.

Ulisses tem 34 anos e sua ex-esposa 37. Uniram-se pelo contrato de conjunção marital, estiveram casados por 05 anos e dissolveram a conjunção marital há 01 ano, aproximadamente. Ulisses é espírita e Cassandra, sua ex-esposa, é atéia. Ambos possuem ensino superior completo sendo que, ele trabalha na área de engenharia e ela na área de secretariado. O nível sócio-econômico de Ulisses se refere à classe B1. O ex-casal não tem filhos e, após um mês de separação, Ulisses iniciou um relacionamento com Aline, sua atual namorada. Após descobrir que Cassandra lhe era infiel, Ulisses lhe pediu a separação e não tiveram, a partir daí, nenhum contato.

Em sua descrição, Ulisses apresenta sua relação afetiva e sexual antes da vivência

da infidelidade amorosa da parceira. Ao ser indagado a respeito da relação afetiva e sexual no casamento, Ulisses destaca que:

antes de eu ficar sabendo tal [da infidelidade], é... era bom [o relacionamento do casal], assim... não tinha nenhuma queixa, gostava de estar junto, programava a vida junto, né?, ah... isso afetivamente falando, sexualmente também era bom, não era ruim, não. A gente tinha um, a gente tinha assim ah... eu viajava muito, na verdade eu viajo por causa do meu emprego, eu viajo bastante, mas quando eu tava de volta era normal assim. [...] nós tínhamos um gosto parecido pras coisas, né?, então, saíamos pra jantar, teatro, cinema, esse tipo de coisa, pegava muito filme pra assistir em casa, eh... o que mais, shopping, gostava de viajar também bastante, assim... esse tipo de coisa. Mas uma coisa que a gente era meio divergente no meu gosto era assim: eu gostava muito de ir na casa de amigos, churrasco, esse tipo de coisa e ela não gostava, isso era divergente. [...] quando era uma situação específica, tipo assim, não um churrasco o dia inteiro, vai ser um churrasco à noite, um grupo pequeno de pessoas, tal, aí a gente ia.

O relacionamento do casal parece fundar-se em princípios igualitários e de igualdade, tão divergentes dos sólidos padrões de diferenças entre os gêneros, estabelecidos 
com a ascensão da família burguesa. Salém (1989); Giddens (1993) e Torres (2002), dentre outros, cunharam categorias a fim de explicitar as formas alternativas de relacionamentos contemporâneos, que se fundam em uma maior democratização quanto às relações entre os gêneros.

Embora a união de Cassandra e Ulisses não tenha sido fundamentada pela fé cristã, a fidelidade amorosa era vigente no relacionamento do casal. Procuraram estabelecer fronteiras menos rígidas entre as atribuições femininas e masculinas, demarcadas ao longo de nossa história familiar ocidental; fronteiras mais diluídas, fundamentadas em decisões conjuntas. Entretanto, ao continuar seu depoimento, Ulisses diz:

o relacionamento afetivo, eu acho assim, depende de pensar muito sobre o que aconteceu [a infidelidade], né?, eu vejo assim: ah... era como um... ah, um era 'pro outro como uma..., era um parceiro, era um parceiro de encarar a vida junto, só que aí, eu comecei ver que eu, ah... eu, invés de ser o parceiro, eu virei a "muleta”, porque quando começamos a namorar, tal, ela trabalhava, eu trabalhava também, tal, aí conforme a gente foi morar junto, vivemos união estável... depois disso, ela falou: "não, eu não quero mais trabalhar”, e aí eu cedi, claro que, com bastante briga, mas eu cedi, aí eu comecei a fazer... a sustentar a casa, aí as coisas começam a ficar apertadas e tal, e ela não queria trabalhar, ela queria ficar tranqüila d'uma vez assim.

No início do relacionamento, Cassandra e Ulisses estabeleceram uma relação mais igualitária, no que tange às atribuições de tarefas entre o casal, bem como na maneira de administrar os afetos e os conflitos. Contudo, com o passar do tempo, um padrão tradicional de divisão de tarefas emerge na relação do casal e pauta-se no desejo feminino de que o homem seja o provedor financeiro do lar.

Ulisses explica:

O problema começou aí, é... porque aí, eu tinha um dilema na minha cabeça, eu falava assim: “eu não sei se...”, na minha cabeça, ela não podia parar de trabalhar, 
porque eu acho que ela tinha que trabalhar 'prá ser produtiva, né?, 'prá tocar a vida dela, ãh... e pra ajudar, sabe?, porque sozinho também era difícil manter o padrão de vida que a gente tinha ali, mas o que eu vejo, assim... eh... os problemas começaram aí, porque o meu dilema era: “ela quer parar de trabalhar, e eu tenho que sustentar a opinião dela porque ela é minha esposa, mas eu não concordo com a opinião dela, o quê que eu vou fazer? Eu vou separar por causa disso? Não eu não vou separar, era concordar com aquilo. [...] É, e de respeitar a opinião, porque eu considerava ela minha esposa, eu tenho que respeitar, mesmo que... ela não quer trabalhar... eu vou tentar mostrar, que ela precisa trabalhar, mas a pessoa não quer, não quer, não quer, aí não teve jeito.

Ulisses vivencia um conflito entre atender ou não à solicitação da esposa, entre assumir o modelo tradicional de relacionamento conjugal, no qual o marido, responsável pela estabilidade econômica do lar, tem o poder de autoridade sob a esposa, submissa e obediente, e assumir um modelo moderno, no qual o diálogo, a negociação constante e os comportamentos mais igualitários são priorizados.

Quanto à sexualidade vivenciada no casamento, Ulisses relata:

O nosso relacionamento sexual era assim, era muito bom, era bem gostoso assim, ela era uma pessoa assim, que não tinha inibições sexuais, problemas, não tinha problema 'prá alcançar orgasmo, 'prá nada, uma pessoa bem atirada, bem..., sabe? Tranqüila mesmo. Ah... algumas vezes eu tinha problema do seguinte tipo: ah... eu acho que o relacionamento sexual sempre é um produto, né?, então, aquele sentimento de companheira, de que você gosta, né?, de tá junto e que faz coisas, que a pessoa faz coisas 'prá te agradar, só faz com que o relacionamento sexual seja melhor, eu sempre achei isso. Algumas vezes, a gente não tinha isso, porque eu não sentia que ela fazia coisas pra me agradar. Aliás, eu acho que ela não fazia força nenhuma 'prá me agradar, então, às vezes não ficava bom.... já era dela isso daí. [...] Então, e eu acho assim: quando tinha alguma coisa que você via que ela 'tava se dedicando, que 'tava tentando agradar e tal, o relacionamento sexual era maravilhoso, bom demais, quando não, era normal, era uma coisa assim, vai..., um relacionamento normal, nada demais. [...] Mas a gente não tinha problemas, talvez, talvez também não tivesse aquele fogo de ir toda hora, de estar 
junto querer e tal, também não tinha não, eu não via isso. Desde o começo, desde o começo, tanto que ela até falava "pô, mas você conta é... das namoradas e tal...”, ela falô no final, né?, e eu não conseguia enxergar isso comigo, eu falei "mas você também não fazia nada 'prá que as coisas acontecessem”. Mas se você... na verdade, se você quiser atingir um nível vai..., mais alto assim... de prazer sexual, se tem que... é um conjunto, não é só o sexo em si, né?. Então, teve mais ou menos essa discussão assim, que eu me lembro.

Ulisses se contradiz: refere-se ao relacionamento sexual ora como satisfatório, ora não, tomando consciência de suas queixas sexuais e das da esposa apenas quando a infidelidade amorosa por parte dela ocorreu e o relacionamento do casal se dissolveu.

Ao desvelar sobre as desilusões com a esposa, Ulisses diz que no início do casamento, os dois trabalhavam na mesma empresa, mas que depois de um tempo sua esposa foi demitida e a partir de então ela não teve mais interesse em buscar um novo emprego no mercado de trabalho. Nesse momento, ela propõe a Ulisses a abertura de uma empresa própria, que ficaria sobre a sua responsabilidade.

vamos fazer estacionamento... dá certo, tal, tal, tal”, eu falei “tá bom”, era o único dinheiro que eu tinha, eu falei “então, vamos abrir um estacionamento”, aí ela foi duas vezes no estacionamento e nunca mais foi. E aí eu, além de estar trabalhando na empresa eu tinha que trabalhar no estacionamento pra aquele negócio andar.

O resultado desse empreendimento para Ulisses foi um grande desapontamento com o desinteresse da parceira:

Então, eu começava a ver que ela, ela se acomodava, e como a gente brigava, mas eu não tomava alguma atitude mais drástica, pra ela tudo bem.[...] ah... mudou [falando da afetividade], mas assim, na verdade eu acho que eu gostava muito, então o que eu disse, por esse, tanto que você cede e eu acabei cedendo tal, eu gostava bastante dela. Ã... mudou no sentido de a pessoa não ser aquela 
companheira que se 'tá esperando, mas isso não mudou... assim... não é uma mudança, assim, significativa de falar não eu não gosto, não é assim, não. É só aquele negócio da frustração, de você estar esperando alguma coisa e não ser. Foi isso aconteceu.

Na medida em que o ideal de amor romântico é abalado, Ulisses vê a figura amada como um ser humano mais falível, menos perfeito; porém, ela demonstra romper o ideal de cumplicidade e companheirismo almejado pelo parceiro.

Embora Ulisses tenha se frustrado com a ruptura da imagem do objeto idealizado, ele não considerava essa realidade como motivo para a separação do casal até a ocorrência da infidelidade amorosa por Cassandra.

Após os momentos descritos até aqui, Ulisses passa a vivenciar a dor e o luto da infidelidade da parceira amada. Ele relata que viajava a trabalho para o exterior com freqüência. Ficava de dois a três meses no exterior, retornava ao Brasil e voltava novamente e, que nos dois últimos anos que antecedeu a infidelidade da esposa, residiu em outro país: AMORA [nome fictício], indo e vindo do país de origem. Foi ao voltar de sua penúltima viagem à AMORA que descobriu a infidelidade da esposa.

Relata que:

eu fui pra AMORA, fiquei dois meses, aí eu voltei e eu percebi que ela [a parceira] 'tava bem fria [se refere a prática sexual], sabe, não se importando mais ... e antes era uma coisa mais quente assim, né?, uma... ela tava bem fria, e aí eu comecei a desconfiar que tinha alguma coisa. Só que eu não via nada [...] Aí me veio o estalo, eu falei: a internet [ênfase], 'tá se comunicando pela internet. [...] descobri um "programinha" que você acaba descobrindo tudo o que a pessoa faz no computador [...] Aí eu peguei a troca de e-mails, ela marcando... aí, ela esperava eu ir dormir e saía... ela conhecia essa pessoa, essa pessoa era do mesmo prédio que a gente morava, conheceu quando eu tava viajando. 
Ulisses revela o distanciamento físico e emocional do casal durante o período em que ele passara em AMORA, que corresponde ao período em que Cassandra mantém uma relação extra-conjugal. Esta nova relação é, entretanto, marcada pelo selo da hipermodernidade em que o universo erótico, mais do que nunca, sede lugar a fantasia, aos fluxos nervosos, a individualidade, ao hedonismo existente no uso dos teclados, nos contatos internáuticos.

Na visão de Debord (1997), a imagem é a maior produção da sociedade do espetáculo, estando o poder na raiz deste. A internet surge enquanto uma das especializadas mediações do espetáculo e, no relato de Ulisses, encontramos a máxima expressão de poder que esta mídia, a internet, tem. É por meio deste instrumento que Cassandra oculta o seu ato, e é também através dele que Ulisses o reconhece.

Ulisses prossegue:

eu falei assim: “o quê que é isso aqui?”, né?, peguei o e-mail, imprimi, e falei: “o quê que é isso aqui?” [refere-se à mensagem de e-mail impressa]. Aí ela..., mas, eu já tava chorando já, aí ela já sacou, né?, aí ela falou assim: “ah... eu preciso falar uma coisa pra você: aconteceu isso, isso, eu conheci a pessoa, comecei a me envolver com a pessoa..., foi assim...” Eu falei assim: “tudo bem”. Ela me contou como aconteceu, aí eu falei: "bom, eu não consigo ficar mais aqui, eu vou embora e quando eu voltar a gente conversa”.

Na visão de Bruns (2006), a perplexidade de Ulisses frente a infidelidade da esposa pode ser compreendida pela perplexidade que temos diante do local onde vemos a ocorrência da transgressão as promessas feitas no matrimônio, ou seja, na intimidade do próprio lar.

É no meio familiar que muitos usuários da internet vêm se valendo dessa "riqueza” midiático para a obtenção de seus prazeres. Prazeres estes que atingem na ótica de Bruns (2006): 
os princípios, os valores e os segredos familiares, uma vez que os compromissos de fidelidade e lealdade declarados pelo casal publicamente, muitos até seguindo rituais e cerimônias religiosos, estão sendo desrespeitados e não mais em encontros secretos fora da intimidade familiar. Encontros esses responsáveis muitas vezes pelas ausências prolongadas de um dos parceiros. Paradoxalmente, a traição virtual é vivenciada na presença do(a) parceiro(a)...

Compreendemos que a vivencia relatada por Ulisses é uma expressão das palavras da autora, pois afinal, a esposa não somente mantém uma relação extra-conjugal, como mantém para essa relação uma comunicação erótica, que se estabelece pelo meio midiático, no próprio lar, na ausência, ou na presença do marido.

Ulisses revela suas reações emocionais frente a esta experiência:

Foi horrível, foi horrível não só porque eu... não só por gostar muito, mas por estar batalhando pelo casal, porque ir pra AMORA pra mim era dificílimo, que lá é um lugar horroroso, então, você ficava lá e aí você pensava que aquele dinheiro que você tava ganhando ali ia proporcionar... e a sua vida e da sua esposa ficasse melhor, né? Então, tudo isso vinha na minha cabeça assim, quando eu vi, né?: “ó, passei um ano lá de bobeira, fiz tudo de bobeira”, sabe? E foi um sentimento de frustração enorme assim, enorme. Aí quando eu vi, eu chorava, eu tremia, fiquei bravo... mas aí..., a primeira coisa que eu fiz foi vir para Jatobá [nome da cidade na qual seus pais residem].

Ulisses não discute com a esposa sobre a situação ocorrida e viaja em seguida para a casa de seus pais, em uma outra cidade, não exteriorizando os sentimentos vividos.

Relata que ao voltar, entra no mesmo programa instalado no computador do casal e descobre, ao entrar em sua conta bancária, que a esposa havia realizado um empréstimo pré-aprovado de 09 mil reais.

Ao ser inquirido sobre os conteúdos presentes nas mensagens trocadas via e-mails, Ulisses relata:

eu acho que o primeiro e-mail que eu peguei, eu acho que foi o mais grave, foi inclusive com palavreado de baixo calão, sabe? [...] e ela marcando, falando coisas assim que... doeu, doeu bastante ver aquele e-mail lá. [...] em relação 
sexual, sexual, que ela falava com palavreado, com palavreado... vai..., chulo, palavreado chulo e marcando encontro, na verdade encontro sexual mesmo com o cara, né?, isso doeu. [...] e eu tinha... aquilo, era assim: ela era minha esposa, você entendeu? Não interessa, era a minha esposa, tinha os erros, tal, tal, tal, mas era a minha esposa, e a partir... daquele e-mail ali, aquilo ali foi meio um que divisor de águas, né? A partir daquilo que eu vi ali, ela já não era mais a minha esposa, então, eu acho que talvez o sentimento de perda que machucou bastante. E aí eu até falei prá ela assim: "óh..., quando você me traiu e eu peguei esses e-mails aqui, você perdeu o marido, quando você me roubou, você perdeu um amigo”, que aí eu não nem... nada.

Ulisses desvela ter sido traído pela esposa no amor e no companheirismo e a partir do momento em que o ideal de companheirismo se desfaz, com a notícia da infidelidade amorosa, bem como da infidelidade quanto ao dinheiro roubado, não deseja mais compartilhar sua vida com Cassandra. Ulisses a desvaloriza, a hostiliza e a abandona.

Segundo Nasio (1993), para que o inconsciente exista é preciso que ele seja escutado e, além disso, reconhecido. O inconsciente revela-se num ato que surpreende e ultrapassa a intenção daquele que fala. O sujeito diz mais do que pretende e, ao dizer, revela sua verdade. Esse ato, mais que revelar um inconsciente oculto e já presente, produz o inconsciente e faz com que ele exista. O reconhecimento do inconsciente não é um reconhecimento do pensar, mas o reconhecimento do ser e necessita que um outro o reconheça. O inconsciente não é individual nem coletivo, mas produzido no espaço do entre-dois, como uma entidade única que atravessa e engloba os atores da análise. O inconsciente é uma linguagem que liga e ata os seres.

No caso da análise, o psicanalista reconhece o inconsciente do outro como ato a partir de seu ser e de seu próprio inconsciente. Em nosso caso específico, podemos dizer que a partir dos relatos explicitados por Ulisses, veicula o saber inconsciente sobre o interesse financeiro que Cassandra lhe tem. 
Ulisses relata como se comportou em relação à família de origem de Cassandra quando ele soube sobre sua infidelidade: “Aí eu tinha um grande dilema, que aí outro grande dilema, que eu falava: e agora? Eu vou contar pros pais dela, ou não?”

Ulisses encontra-se mais uma vez dividido entre assumir um padrão de comportamento conservador ou um padrão de comportamento individualista, ou seja, dividido entre assumir um comportamento de comprometimento e respeito em relação à família de origem de Cassandra, compartilhando com ela a notícia da dissolução da união do casal, ou não visitá-los, quando esteve em JATOBÁ [cidade em que seus pais e os dela residem]. É possível notar, portanto, no comportamento de dor de Ulisses, a constante contradição entre assumir uma postura conservadora ou uma postura individualista, que tende a imperar não somente nas relações afetivas e sexuais da sociedade hipermoderna, mas também nas relações sociais como um todo, fazendo com que o ser humano, submetido aos apelos do mundo contemporâneo, não saiba ao certo como se comportar.

Tendo em mente os aspectos do fenômeno tratados até o momento, passaremos agora a apresentar uma outra dimensão existencial, ou seja, a re-significação do relacionamento amoroso na perspectiva de Ulisses, que é baseada no fim do relacionamento no qual houve a infidelidade e na construção de uma nova relação amorosa e afetiva com uma terceira pessoa.

Ulisses revela um pouco mais sobre sua vivência pós-separação:

É engraçado que depois eu ãh... eu tinha um sentimento ... dentro do relacionamento quando eu tava com ela ... de prisão, eu tava preso, mas preso assim... porque algumas coisas que eu adorava fazer e não fazia porque eu cedia muito fácil, sabe?, eu não fazia, coisas assim, tipo lá em CAJA [nome fictício da cidade em que residem], tem um lugar lá que eu ia lá sábado de manhã andar de bicicleta com os amigos, fazer uma ginástica ou mesmo sair de empresa e ir fazer uma academia, aí ela argumentava assim: "ah, mas você fica longe tanto tempo e 
aí quando você volta você vai fazer academia, vai chegar tarde em casa, não sei o que..., a gente não tem tempo de conviver...”, eu falei: “ah... é verdade”, aí mesmo nos programas de final de semana né?, eu deixava de ir lá. [...] e eu acabava cedendo sempre "não, você tem razão, cê tem razão”, e aí a coisa foi se distanciando, distanciando dos meus amigos, até da minha família, eu vinha muito pouco pra cá [cidade em que os seus pais residem], eu vinha uma vez por mês, quando vinha.

E continua:

logo depois [da separação] eu vinha pra cá direto, até hoje né?, ah... churrasco com os amigos direto, festa direto lá em CAJA [cidade em que reside], sempre, tudo, tudo, tudo o que eu não tava fazendo eu comecei a fazer, tudo.

Após a separação, Ulisses retoma algumas atividades que gostava de fazer e pelas quais era recriminado pela ex-esposa.

Revela ainda que:

Às vezes, eu falo que foi até bom ter acontecido desse jeito mesmo pra que não tivesse nenhuma volta, não tem volta, isso aqui aconteceu, é um divisor de águas na sua vida... vai pra frente, vai fazer o que você quer fazer. Acho que foi bom. Hoje eu vejo tudo numa ótica mais tranqüila, né?, mais... bem, mais tranqüila assim. Até dô risada das coisas porque... fiquei até cinco horas da manhã estudando pra arranjar aquele programa pra descobrir como que eu ia ver os emails, tinha que estudar, estudar, aí esse aqui não dá e tal e tal, aí coloquei um lá, ah... esse daqui dá, aí funcionou [risos]. [...] E hoje eu rio, hoje... pra mim, sabe? Pra mim foi uma época difícil, bem difícil, mas que passou. E hoje em dia, ainda te digo mais, hoje em dia eu acho que eu não teria nem problema de encontrar, né? Acho até que se encontrasse ela com o cara, eu nem conheço o cara, se encontrasse ia ser numa boa assim, passou mesmo, é inacreditável, não tem problema nenhum....

O relato acima deixa claro que a não aceitação pelo homem, da infidelidade feminina, que longe de ser algo tão distante de nossa época, tal como apontamos nos 
discursos de Vainfas (1986); Lins (1997) e Chauí (1991), dentre outros, atualiza-se na relação amorosa de Ulisses e Cassandra.

Ao relatar sobre o novo relacionamento após a separação do casal, Ulisses revela:

O novo relacionamento foi fundamental, eu acho, foi fundamental. Eu falo até 'prá ela [para a nova parceira], né?, que ela foi a minha muleta psicológica, eu acho [risos], foi um suporte enorme. Tem uma coisa que é assim, né?, quando eu fui pra Amora, pra mim lá na Amora é terrível, e na amora eu sempre, assim, é um lugar muito difícil, você fica muito sozinho lá, sozinho mesmo, as pessoas até... cê vê que fica carente, a pessoa fica carente lá... Aí você precisa de alguém pra poder ligar, cê ter alguém que você fale: “nossa, essa pessoa 'tá comigo”, e eu tinha um medo enorme disso, quando eu me separei da Cassandra, o nome dela é Cassandra, né?, eu falei: "meu, vai ser terrível lá na Amora, eu vou achar que a minha vida 'tá lá embaixo. E eu já 'tava namorando com a Aline, a última vez que eu fui eu já 'tava namorando com a Aline, e aí foi... era aquilo, era aquela segurança: “eu tenho uma pessoa lá no Brasil assim, assado...”, eu ligava sempre contava o que 'tava acontecendo lá, etc. Então foi super bom 'prá mim, aquilo foi o que eu precisava, ela foi 'prá mim... hoje a gente 'tá meio brigado, mas aí..., mas, na época foi sensacional, nossa!

Percebemos no depoimento acima que o apoio da família e dos amigos no momento de separação e no período pós-separação mostra-se fundamental, de modo que mais rápido será o processo de ajustamento psíquico quanto mais interação social houver. Além disso, é possível notar que um novo relacionamento contribui para o aumento da auto-estima e para a adaptação a vida sem o(a) ex-parceiro(a).

Continua:

A Aline... tem uma coisa que é em comum [em comum com a ex-esposa], que eu acho, olha, a Cassandra era extremamente ciumenta, extremamente ciumenta e hoje a Aline é extremamente ciumenta, eu não entendo, mas ciumenta de uma maneira assim, de eu não poder ir almoçar no Shopping Center lá..., na hora do almoço na empresa tem o shopping do lado e eu vou almoçar no shopping com os amigos mesmo, não vai nenhuma mulher, só homem, ciúme... Se é meu 
comportamento que desperta esse ciúmes..., mas eu não vejo aonde?, cê entendeu? eu não vejo aonde que esse ciúme tá..., eu vejo ... até faz mal, eu acho, não é uma coisa sadia.

Este relato revela um processo de "transferência”, o qual designa um processo pelo qual desejos inconscientes de um indivíduo, concernentes a objetos externos, passam a se repetir na pessoa de outros (Roudinesco \& Plon, 1997). No relato de Ulisses observamos a referência que ele faz ao ciúme de Cassandra e ao ciúme de Aline e, assim, estabelece uma relação transferencial.

Na ótica de Nasio (1993), podemos dizer que o sintoma é um significante, se o considerarmos como um acontecimento do qual não domino nem a causa, nem o sentido, nem a repetição e como significante, o sintoma se impõe, escapa-nos, repete, interroga-nos e nos questiona. No caso da análise, o significante aparece no momento exato, como uma peça indispensável, para suscitar no paciente e no analista a pergunta adequada que dá acesso ao inconsciente considerado como um saber. O sujeito-suposto-saber não interroga o sintoma como signo, pois não é "o por que” que o preocupa, mas "o como". Como se organizam os acontecimentos de sua vida? Qual é a ordem da repetição? Estas perguntas nos conduzem à hipótese do inconsciente como estrutura. Desse modo, para Nasio (1993, p.21):

Tomar o sofrimento do sintoma pelo ângulo da causa é fazer dele um signo, ao passo que surpreender-me por sofrer essa mesma infelicidade num instante propício, como se ela fosse imposta por um saber que ignoro, é reconhecê-lo como significante.

Como já dissemos anteriormente, o inconsciente é o saber atemporal, o saber da repetição, é o momento que assegura a repetição, de modo que o significante se repete, podendo se encontrar indiferentemente numa pessoa ou noutra. O significante salta de um 
sujeito para outro, onde a ronda ordenada de elementos já repetidos ou por se repetir, essa estrutura, não pertence a ninguém. Desse modo, podemos apontar a repetição que surge como um significante no momento em que Ulisses fala da semelhança entre o comportamento ciumento de Cassandra e de Aline.

Continuando ainda o seu relato, diz como se sente em relação ao ciúme de Aline [sobre essa relação transferencial]:

preocupado por... não que eu acho que vai haver alguma traição não, mas de um padrão de relacionamento que vai se repetir, de prisão, de não fazer as coisas, sabe?, isso me perturba. Tanto que hoje a gente tá meio brigado nesse relacionamento justamente por causa disso. Eu falei: “meu, eu não quero de novo, eu quero ter liberdade prá fazer as coisas... claro que, eu fazer junto com você ou fazer eu mesmo", nada que seja... coisas ... normal, né? Me incomoda assim... eh... porque na verdade, às vezes ela me cobra coisas e prô lado dela, ela não age dessa maneira, isso me incomoda, eu acho.

A partir deste relato podemos dizer que o saber veiculado por Ulisses não revela quem é essa pessoa da qual ele fala, pois o discurso que nos fez sobre Cassandra se repete ao falar de Aline, de modo que a pessoa é outra, mas a cena, o significante, a forma de se relacionar continua a mesma.

Agora, passaremos à compreensão e interpretação da descrição da temporalidade de Páris, no que diz respeito ao fenômeno da infidelidade e da re-significação do relacionamento amoroso. 


\section{Páris}

Entrevista realizada em 04 de Abril de 2005.

Páris tem 33 anos e sua ex-esposa tem 32 anos. Foram casados por 07 anos no civil e no religioso e estão separados judicialmente há aproximadamente 02 anos. Casou-se aos 25 anos de idade e sua ex-esposa aos 24 anos de idade. A religião de Páris é católica e a de sua ex-esposa é espírita. Ambos possuem ensino superior incompleto, sendo que ele trabalha na área de informática e Helena, sua ex-esposa, na área de secretariado. O nível econômico de Páris corresponde à classe C e eles tem um filho, com 10 anos, que reside com o pai. Ele relata que após tomar conhecimento que sua esposa lhe era infiel, pediu-lhe a separação. Consensualmente, Helena se separou de Páris e passou a viver numa relação homossexual com Mariana, com quem manteve um relacionamento extraconjugal, antes da separação.

Em sua descrição, ao relatar sobre suas vivências amorosas na adolescência, juventude e namoro, Páris diz que antes de ter conhecido Helena tivera outras namoradas: “eu tive várias namoradas, eh::.... eu nunca fui nenhum 'galã de cinema’ assim... mas eu saí com bastante meninas, conheci bastante gente e ela [esposa] sempre achou que eu tinha cara de sem-vergonha”.

Seu discurso desvela uma crença em seu poder de sedução, capaz de conquistar várias garotas e o que levava inclusive a parceira a desconfiar de sua fidelidade.

Relata ainda o modo no qual sempre se comportou em relação à separação nos relacionamentos anteriores: "nenhuma vez depois que eu terminei o relacionamento, com nenhuma outra pessoa eu voltei atrás ou busquei a reconciliação, tal, eu sempre tive aquela coisa, a partir do momento que eu tomo uma decisão, mesmo que eh::... eu sofra ou que sei lá..., eu não volto atrás”. 
Parece-nos que o modo do colaborador realizar suas escolhas se dá por meio de elaborações que podemos chamar de pouco reflexivas ou racionais, segundo a perspectiva fenomenológica. "Racionalizar” é, para Forghieri (2001, p.43-43), debruçar-se sobre o passado, refletir sobre o que já aconteceu e fazer previsões, sobre o que poderá vir a acontecer”. Atitudes bruscas, decididas sem reflexões parecem serem contraditórias a esse modo de se relacionar com os acontecimentos.

Nessa perspectiva, a apreensão da realidade requer uma abertura do ser humano à compreensão de suas vivências e não simplesmente, no que a Psicanálise denomina de “racionalização”.

Prosseguindo em sua descrição, o colaborador relata sobre as suas relações afetivas

\section{e sexuais no casamento, antes de Helena lhe ser infiel.}

acho que todo casal quando se casa, ninguém se casa pensando em se separar, então foi... foi legal [se refere ao início do casamento]. A gente se dava muito bem, apesar que depois, claro, você analisando você vê que algumas coisas eh:::..., no momento quando você 'tá vivendo ali 'cê num, num consegui ver muitas coisas, 'né?, depois que a gente se separou, aí começa a perceber algumas coisas que faltavam desde o início, como um diálogo mais... eh::.... freqüente dos dois, conversar mais sobre muitas coisas, eh::.... se abrir mais um com o outro.

Percebemos que na percepção de Páris, o casamento se pauta na visão romântica de durabilidade do casamento, consoante com a crença cristã. Ele revela uma contradição: desvela num primeiro momento a tomada brusca de decisões, tomadas acertativamente e, se volta, num segundo momento, para uma queixa pertinente na relação do casal, a falta do diálogo, do compartilhar de intimidades.

Páris relembra as situações vivenciadas no início do casamento e diz que foi “um bom período":

por eu ficar mais tempo em casa, eu ter um horário, assim, mais tranqüilo. [...] foi um período que ela 'tava grávida também, então sempre acompanhava ela ao médico, eh... todo início de casamento eu acho que, pelas pessoas que eu conheço também, é sempre aquela coisa tranqüila, mesmo que você tenha 
namorado sei lá quanto tempo, mas a partir do momento que você começa a viver junto é uma coisa diferente, eh... eu acho que é sempre aquela coisa meio nova, é... você vai descobrindo muitas coisas.

Percebemos que diferentemente das descrições femininas que se referiram ao período de gravidez do casal como um período conflitante, Páris remete a esse tempo com saudosismo. Relata ainda que nesse período, no inicio do casamento, “que determinadas coisas você deixa 'prá lá, releva, mesmo que alguma coisinha, alguma coisinha que poderia gerar uma discussão tal, mas a gente finge que entende, finge que tá bom e deixa pra lá....”

Prosseguindo, ele relata que apesar de nos dois primeiros anos de casado eles terem se dado muito bem, período em que não tinham nem brigas, nem desentendimentos, ele revela, em contrapartida, uma queixa sexual, que já imprimia a sua presença desde o início do casamento:

Apesar que, eh::... mesmo nesses dois anos, que foi um período assim... legal, houve vezes assim que, que... eh.:.... o lado sexual... eu sentia que ela, em determinados momentos, assim... eu sentia um certo desinteresse dela, 'né?, eh::... toda ah..., ah..., como seria a palavra..., toda iniciativa, iniciativa sexual teria que partir de mim, 'né?.

Seu discurso afirma um comportamento sexual que se manifestava somente a partir da iniciativa do marido e prosseguindo ele diz: "teve vezes assim que eu ficava eh::....., deixava... rolar 'prá ver até quando ela iria ficar passiva sem tomar uma iniciativa, ficava dias, às vezes duas semanas assim na minha, 'prá ver até quando ela iria tomar uma iniciativa, pra ver a reação dela”.

E, em seguida, o eu narcísico se contradiz: “não sei, às vezes eu sentia que ela não tinha eh::.... muito interesse, eh::.... outras vezes não, só que normalmente quando a iniciativa partia de mim, aí rolava legal, mas se eu não tomasse a iniciativa muitas vezes num... ela também não fazia nada. 
Desvela ainda que quando essa situação acontecia nenhum dos dois questionava o outro: “então sempre ficou uma coisa assim.. eh:::. eu faço que entendo e nunca teve um diálogo mais profundo sobre determinadas coisas [os assuntos sexuais]”.

Ao ser indagado sobre seus sentimentos frente a essa situação, ele diz:

era difícil porque, eh::.... às vezes eu sentia que ah::..., eh... eu não conseguia satisfazer eh... o que ela queria, 'né?, e outras vezes não, outras vezes eh... eu sentia que ela tinha eh... que ela tinha gostado, então ficava aquela coisa assim eh:::... umas vezes foi bom, outras vezes não foi, mas sempre ficava "no ar" as coisas e nunca teve assim, eh... diálogo, por que sim ou por que não, então...

Seu relato demonstra como Páris se sentia confuso e impotente frente a vivência da sexualidade no casamento e desvela as suas dificuldades em descrever seus sentimentos, bem como compartilhar com os outros aos seu redor, as suas sensações, percepções, inseguranças e mitos.

Prosseguindo em sua descrição, o colaborador relata que quando por exigências da empresa em que trabalhava tivera que aumentar a sua carga horária de trabalho permanecendo em casa por menos tempo, isto o levou a ter desentendimentos entre o casal e motivou a desconfiança de Helena em relação a fidelidade de Páris, "ela sempre teve um ciúmes assim... doentio, por mim”, mesmo ele lhe ter sido sempre fiel, desde o começo do namoro.

Prosseguindo, o colaborador revela o seu descontentamento:

se a gente 'tava na rua e a gente encontrasse com uma amiga minha e eu falasse: 'oi’ [...] se a gente ficasse andando na rua mais duas horas o humor já tinha mudado totalmente, tipo não conversar mais, não falar mais nada, e a conversa posterior, assim em casa tal, “quem que era ‘aquela uma’ que você falou aí na rua? da onde você conhece?”. E coisas mais ‘chulas’ assim, tipo... - “já comeu também?” [...] na maioria das vezes eu tentava explicar [...] não mudava em nada o conceito que ela já tinha pré-definido. [...] Eu achava que esse tipo de coisa dela era meio "neurose”, achava que eh:.... isso aí era a... "neurose da cabeça dela”. E eu achava que isso aí era muito ruim... 
Assim, como encontramos nas descrições relatas por outros colaboradores, o ciúme também faz morada nas vivências relatadas por Páris, nem com tanta agressividade que habitou as relações de Stela e de Romeu com seus pares amorosos, mas como uma tentativa de limitar e de controlar o eleito amado, característica esta que é segundo Gikovate (2006), inerente a esse sentimento.

Não podemos no entanto, indagar o que move, nesse caso, o ciúmes da amada: se se refere ao medo de lidar com as frustrações, com o sofrimento psíquico ou com as perdas. O que podemos dizer é que, embora seja vivido e relatado, ele não vem acompanhado da violência.

Prosseguindo em sua descrição, Páris relata que um pouco antes de descobrir sobre a infidelidade de Helena, as desconfianças e acusações dela para com ele eram freqüentes e que isto tornou a relação “um fardo esperando o tempo passar”. Relata também que Helena começou a chegar tarde em casa, que o desinteresse sexual ia cada vez mais aumentando e que tinha uma amiga em especial, com que “saía” muito, como expressa no relato abaixo:

até chegar ao ponto que ela não queria mais eh::... transar comigo... não tinha mais sexo. Era uma coisa assim tipo subentendida, tipo é... de sei lá, eu ir 'prô banheiro 'prá tomar banho ela já ia pra cama deitar, a hora que eu saia do banheiro ela já tava dormindo, eu fingindo pelo menos que estava dormindo. Então era uma coisa assim desencontrada dentro de casa, eh... primeiro, a primeira oportunidade assim que ela tinha assim de dez minutos longe de mim assim... ela já tava dormindo ou tipo, se ela não tinha essa oportunidade assim, ela ficava na televisão até... eu dormir assim. Então era uma coisa mais ou menos assim, e... ela começou a ter umas atitudes é... [pausa de 5 segundos] estranhas digamos assim, e... sempre quando ela chegava tarde, assim saia tal, ela sempre tava com uma determinada amiga, - "eu tava com tal pessoa” -, e essa pessoa é uma pessoa que ela conheceu no local de trabalho dela, falou que veio de outra cidade 'prá trabalhar lá...

Prosseguindo em sua descrição, ele relata que começou a desconfiar que Helena lhe estava sendo infiel com essa amiga próxima a qual despendia bastante atenção para com 
sua esposa que ao viajar a trabalho sempre dormia na casa da amiga e sempre que indagava sobre a amiga, a esposa: “sempre 'saia fora', se esquivava, tal assim..., e num dava seqüência na conversa”.

Relata ainda que:

E eu comecei ao eh::... esse tipo de coisa, quando eu tenho uma curiosidade assim em alguma coisa eu até... até descobrir totalmente o que é...[...] eu comecei “dar corda” e deixar pra ver até onde ia a situação e aí até chegou um momento quando ela disse que não dava mais, que ela queria se separar e ela... achava que não 'tava legal, que a gente devia se separar, né? Quando ela chegou a falar isso digamos que não tinha mais relação, é... nem afetiva e nem sexual, sexo eu acho que já...

Seu discurso desvela que a vivencia da sexualidade passou a ser um indicativo da qualidade da relação-a-dois, tendo esta se findado quando o sexo já não era mais praticado no casamento.

Páris relata que do momento em que começou a desconfiar da infidelidade dela até o momento em que ela diz desejar se separar, se passaram aproximadamente dois meses. E desvela também que o relacionamento afetivo também tinha tomado novos rumos: “era tipo duas pessoas que moravam na mesma casa, nada mais que isso...” e compreendemos com esse relato que o afeto e o sexo parecem estar indissociados, na vivência desse casal.

Sendo assim, outra dimensão existencial do fenômeno, denominada: amor, dor e luto, nos revelará como Páris vivencia os sentimentos de dor e o processo de luto, em relação a infidelidade da amada.

Páris relata que foi numa competição de ciclismo na qual sua esposa competia que confirmou a infidelidade dela e assim, nos relata a cena desta descoberta:

quase próximo da categoria dela começar, elas [a esposa e amante] chegaram, né?, e no momento que ela 'tava correndo eu fui até essa pessoa [a suposta amante] e despretensiosamente perguntei se ela gostava de ciclismo tal, não sei o quê, e fiquei ali tentando puxar uma conversa com ela”. 
Continuando, ele relata:

eu acho que tinha rolado uns quinze minutos mais ou menos de prova [...] a hora que ela me viu conversando com ela ali, na próxima volta ela abandonou a corrida, 'né?, ela abandonou a corrida e 'tava super nervosa, assim sabe?, eh::... só que sem um direção 'prô nervosismo dela, uma coisa meia no ar. E... eu fiquei ali, sempre procurando ficar junto ali. [...] ela falou que se sentiu mal, que não 'tava bem, alguém tentou derrubá-la, mas ficou uma coisa, assim... vaga, 'né? [...] Aí ela falou: - "ah... então vâmo embora, 'né?” -, falou 'prá ela [suposta amante] tal, eu falei: - “não, tem lugar no ônibus 'prá você”, aí ela ficou meio... [...] eu senti que aquilo deu uma atrapalhada nos planos dela, aí ela ainda tentou colocar algum empecilho [...] quando ela viu que não tinha como justificar nada, aí ela: - "a beleza” - [e retorna para casa com o marido].

Percebemos com esse relato que Helena se desestabiliza. Ao contrário do que percebemos nas vivências descritas pelas colaboradoras cujos espelhos narcísicos desabaram no momento em que descobriram a infidelidade dos maridos, compreendemos que Páris mantém-se sensato ao suspeitar que estava com a amante da esposa e quem parece perder-se no espaço e no tempo, é Helena, que se comporta como se estivesse sido pega em flagrante (Nasio, 1997).

Ao continuar ele diz:

fui ‘prô ônibus, levei a bicicleta dela 'prá lá e aí ela foi até o carro tal [se refere ao carro da amante], de longe eu fiquei observando, aí elas se despediram tal, aí... eu tenho, assim, um senso de observação muito bom, pelo menos eu acho, e... quando eu olhei assim... o modo como as duas se despediram assim..., tal eh::... foi nesse momento que eu tive certeza, 'né?

Compreendemos pois, nesse relato, que o funcionamento simultâneo de espelhos narcísicos recíprocos ao casal colocam em consonância seus dinamismos e assim, se assimilam mediante um estado emocional muito próximo que compartilha um sentimento e um ato, a infidelidade amorosa que se desvela no comportamento de Helena (Eiguer, 1985).

Prosseguindo em sua descrição, Páris relata que: 
quando a gente chegou em casa que foi tranqüilo tal, não sei o que, aí eu cheguei prá ela e falei que eu tinha certeza já que ela tava saindo com alguém, que há um tempo já ela 'tava saindo com alguém, né?, só que eu não sabia que ao invés de ser outro homem, era uma mulher, né? Aí foi a hora que ela, digamos assim, ela gelou, ela ficou branca na hora que eu disse isso, né?, e... aí ela admitiu que 'tava saindo com essa outra, que tinha se interessado por ela tal, não sei o que...

Esse relato revela de fato a infidelidade da parceira e percebemos que ao contrário de Helena, Páris parece vivenciar essa situação expressando uma maneira tranqüila de existir, de lidar com tal situação.

Podemos dizer que desde os dois primeiros anos de casamento, Páris vivenciou momentos de angústia que se retratavam em silenciosas dúvidas, mas que no que se refere a infidelidade da parceira, um processo de desinvestimento do objeto amado, já havia se iniciado bem antes a descoberta de que ela lhe era infiel, quando Helena demonstra se desinteressar sexualmente pelo casamento.

Segundo a perspectiva de Nasio (1997), a forma de Páris reage à dor é como se ele estivesse preparado para ver a amada partir, como se o “trabalho de luto” já tivesse iniciado bem antes desta partida. E compreendemos também que para Helena, a perda de Páris torna-se súbita e imprevisível, pois ela não esperava que Páris a desvelasse tão bem, mudando inclusive, suas referências sobre si mesma.

Prosseguindo, o colaborador relata:

eu acho que se fosse eh::... quando ela me disse que queria se separar ela falasse isso [que estava se relacionando com uma mulher], eu acho que a minha reação ia ser bem diferente, sei lá..., mas como eu fui, digamos assim, eu fui assimilando aquela possibilidade, aí depois eu tive a confirmação, é... claro, eu me senti muito mal, eu fiquei um tempinho assim ainda... eh... sei lá, eh... apesar do nosso relacionamento já estar muito desgastado, caminhando mesmo pra um final.

Percebemos com esse relato o tanto que o luto da perda do eleito amado fora elaboradora antes mesmo de sua confirmação e prosseguindo, ele diz: 
no momento em que a gente decidiu se casar eh... eu coloquei isso prá ela, ela também colocou isso prá mim, que se em determinado momento acontecesse alguma coisa da gente eh... não quisesse mais ficar com o outro, que se interessasse por uma outra pessoa tal, antes que alguém se magoasse, que acontecesse alguma coisa, chegar e falar “ó, não 'tá mais legal, eu quero parar por aqui, eu quero dar outro rumo na minha vida tal”. Então, só que isso não aconteceu, isso não aconteceu.

As descrições de Páris desvelam que as relações extraconjugais não ocupam exclusivamente os espaços das relações heterossexuais. Em seu último relato, percebemos que o colaborador atribui significações à traição que vão além do estabelecimento de uma relação genital e/ou uma relação homossexual fora do casamento, mas que implica em uma quebra do pacto conjugal, na manutenção de um segredo que não é compartilhado com o cônjuge, mas com outrem (Zampieri, 2004).

Páris relata que ao dizer que “ já fazia muito tempo que ela queria se separar, não era ali que ela tinha decidido se separar, fazia mais de um ano, tal” e assim, o ego narcísico a indaga sobre o porque ela não lhe dissera isso há mais tempo ao invés de ter esperado substituí-lo e prosseguindo em sua descrição, revela que:

Eu acho que eu fiquei meio assim paralisado, paralisado eh... é.... não sei, eu acho que uma reação assim de... eu não sei se eu fiquei mais feliz ou mais triste, né?, mais triste porque eu tive certeza que era aquilo mesmo que 'tava acontecendo, aquela dúvida, aquela coisa, se olhar assim eh... é... sei lá, como qualquer coisa que você esteja pensando em fazer e ver um final é... um desfecho 'prá aquilo, sei lá, uma outra coisa qualquer que você esteja fazendo e você vê ali o desfecho, que você tem a certeza que era aquilo mesmo 'né?, você fica feliz porque você conseguiu chegar num final, num resultado que você imaginava. Aquele negócio de dúvida, de você ficar imaginando, não deixando a sua mente voar muito prá não cair em “neuroses”, mas ao mesmo tempo não ter certeza do que é, do que está acontecendo.

Quando Páris relata que “não é bom a sua mente voar muito e cair em neuroses”, podemos compreender um pouco melhor as suas atitudes de criticar as "neuroses”, o ciúme de Helena, pois enquanto ela vivia a todo momento questionando sobre a fidelidade dele, 
em contrapartida era ela a infiel. O colaborador parece, pois ter se sentido enganado, traído. Ao mesmo tempo em que é traído, porém, ele manifesta com a descoberta da traição da amada, um contentamento, a satisfação de quem pode compreender a sua existência e a de seus semelhantes, as suas limitações e a de seus semelhantes, a satisfação daquele que pode compreender que o que lhe é transmitido veladamente pelo outro é de fato real.

Paris relata que Helena demorou-se para mudar de casa e que teve dificuldades em contar para a sua família que iria se separar, como demonstra o relato abaixo:

então, ela foi postergando isso e num falava tal e aí eu comecei a cobrar e ela não dava uma solução, nada, e... aí eu num me lembro bem assim quando foi o ponto, assim, que eu falei “então eu vou tomar uma atitude, porque a situação também não pode ficar assim, e agora é a minha vida que você tá atrapalhando. [...]

Decide então “dar uma ajudinha para que isso [a separação] se resolva: chamei os pais dela lá em casa, levei os pais dela lá em casa, e... falei pra eles, eu falei “ó, eh... a uns sete anos atrás eu fui até vocês, falei que eu queria me casar com a sua filha tal, aquele blá, blá, blá todo, e agora eu tô dizendo o contrário, eh... eu tô chamando vocês aqui prá dizer que a gente vai se separar e ela vai dizer prá vocês quais são motivos que levaram isso a acontecer”. Aí ela começou chorar, que não sabia o que falava, a irmã dela, eu levei a irmã dela junto também, a irmã mais velha dela, que aí a irmã dela já sabia o que 'tava acontecendo né?, eu já tinha contado...

Compreendemos com esse relato que a honra de Páris enquanto homem permanece mantida, uma vez que relata para a família da esposa infiel porque é que não pode mais viver com ela. Ele ainda diz: “o pai dela, então... ficou muito envergonhado, não sabia nem como olhar prá minha cara, a mãe dela chorava, ficou desesperada e a irmã dela ficou perplexa, né?, eh:.. eh:.. não imaginava que aquilo estava acontecendo”.

Compreendemos com esse relato que a dor familiar diante do novo é marcada pela subtaneidade, não podendo ser, pois assimilada pelo eu e gerando assim, sentimentos de 
desespero como relata o colaborador, enquanto que para ele, sua ferida narcísica estava, nesse momento, quase cicatrizada.

Páris e Helena se separam e prosseguindo em sua descrição, Páris revela sobre uma dimensão existencial do fenômeno que se refere à dinâmica da infidelidade e sua relação com o filho do casal. A ocorrência da infidelidade amorosa teve como conseqüência, no caso de Paris, a separação do casal. Na perspectiva de Páris:

\begin{abstract}
quando um casal se separa e tem uma criança no meio, a maioria das vezes a criança sofre muito, eu acho que na cabeça dela [da criança] os pais são, assim, uma família perfeita, né?, aquilo nunca pode acontecer na família dela, e muitas vezes isso destrói, assim, a criança, né?, normalmente quem mais sofre é ela. E eu sempre, a partir de um certo tempo eu comecei, o meu pensamento começou a ser assim: "eu vou suportar mais um tempo, a partir do momento que meu filho tiver uma cabeça legal, um entendimento legal eu me separo.
\end{abstract}

Seu relato desvela uma crença dupla: a de que a criança é o membro da família que mais sofre com a separação dos pais e a de que a criança não tem condições de compreender determinados assuntos, como aqueles que se referem à dor e devem, por isso, serem “protegidas” pelo silêncio ou ocultamento da verdade. Sendo assim, no período separação: "sempre que eu queria ter uma conversa assim... mais séria com ela [...] eu pegava meu filho, levava 'prá casa da minha mãe, deixava ele longe e ficava com ela a sós”.

Páris relata que a guarda do filho pertence a ele, que este reside com o pai desde a separação, mas que a criança sempre esteve com a mãe sempre que desejou, fosse para estar ou para dormir na casa dela. Contudo, percebemos no relato abaixo que o colaborador desvela os seus preconceitos frente às relações homossexuais:

eu eu não sabia que tipo de relação ela tava tendo, sei lá, se era uma coisa que ia se tornar tranqüila ou doentia, não sabia o que Helena pensava em fazer, de repente ela pensava em ir embora pra MELÃO morar com essa outra pessoa, e vai arrastar meu filho sei lá 'prá onde, em que tipo de ambiente que ele vai viver, 
então, a guarda dele ficou comigo e a casa também, e casa hoje na verdade é dele, a casa 'tá no nome dele.

Ao prosseguir em sua descrição, podemos compreender os novos sentidos que Páris concedeu ao seu relacionamento com Helena após ela lhe ter sido infiel, bem como atribui à separação do casal.

Páris relata que a preocupação que teve com o filho foi re-significada:

essa foi a parte [os sentimentos e as preocupações do filho em relação a separação] que eu achava assim que, essa era a parte que mais me preocupava, mas acabou sendo a parte mais tranqüila, e eu acho que eu tenho a sorte de... meu filho ele, ele, é bastante esperto, bastante inteligente, e... às vezes a gente acha que a criança não percebe muito as coisas, mas ela percebe né.

Mesmo no primeiro ano de separação do casal, o colaborador se lembra das pessoas terem perguntado à criança como se sentia e ela respondia: “não, agora tá ótimo, eles pararam de brigar, tá muito bom”.

Prosseguindo, ele relata sobre o seu relacionamento com a ex-esposa:

hoje nosso relacionamento é super tranqüilo, ela treina, eu oriento os treinos dela tal, hoje... eu acho que depois que a gente se separou tudo, depois que passou um tempo aí eh... aquele tempo de mágoa e tal, hoje é um relacionamento eu acho super tranqüilo. Eh::.... eu acho até que eu tenho um pouco de pena de como ela age com determinadas coisas, isso 'prá mim hoje, não influi em nada.

E desvela que sem ressentimentos e sem agressões, Paris e Helena mantêm relações profissionais e sociais amigavelmente.

Após termos apresentado a análise das descrições dos(das) colaboradores(as) dessa investigação, apresentaremos, no próximo capítulo, a síntese desta análise com o intento de delinear a estrutura geral do fenômeno que nós indagamos: quais significados homens e mulheres atribuem a vivência da infidelidade do(da) parceiro(a) e como re-significam sua relações amorosas após estes(estas) lhes terem sido infiéis. 
CAPÍTULO 5. PERPLEXIDADE, DOR E LUTO: A RE-SIGNIFICAÇÃO DO AMOR E DA INFIDELIDADE VIVENCIADOS POR HOMENS E MULHERES.

“A paz invadiu o meu coração
De repente me encheu de paz
Como se o vento de um tufão
Arrancasse os meus pés do chão
Onde eu já não me enterro mais
A paz fez um mar da revolução
Invadir o meu destino a paz
Como aquela grande explosão
De uma bomba sobre o Japão
Fez nascer o Japão na paz

Eu pensei em mim eu pensei em ti Eu chorei por nós Que contradição só a guerra faz Nosso amor em paz Eu vim

vim parar na beira do cais Onde a estrada chegou ao fim

Onde o fim da tarde é lilás Onde o mar arrebenta em mim

O lamento de tantos ais A paz invadiu o meu coração”.

Gilberto Gil

A partir de uma trajetória de reflexões acerca da temática da infidelidade amorosa iniciamos esse trabalho a fim de desvelar quais significados homens e mulheres atribuem a vivência da infidelidade amorosa do(a) parceiro(a) e como re-significam a relação amorosa 
após estes(estas) lhes terem sido infiéis. Em meio às dificuldades quanto a contatação de colaboradores(as) que pudessem compartilhar conosco suas vivências pessoais, alguns homens e mulheres mergulharam em suas mais íntimas vivências de amor e dor concedendo-nos suas descrições. Utilizamos o método fenomenológico descritivo proposto por Rezende (1990). Submetemos as descrições dos(das) colaboradores(as) aos momentos da análise, tais como descritos por Giorgi (1978) e Bruns (2003) e situamos o fenômeno em sua temporalidade e em sua construção sócio-histórica-cultural, bem como buscamos a sua compreensão psicológica interpretando-o à luz da Psicanálise.

Apresentaremos nesse momento, algumas reflexões sobre os significados que foram atribuídos por homens e mulheres ao fenômeno indagado, levando o leitor a ter uma síntese compreensiva geral.

Esse trabalho nos possibilitou compreender que, embora o cenário contemporâneo seja permeado pela busca do prazer imediato, pela exaltação da individualidade, pelo hiperconsumismo, pela espetacularidade e pelo frenesi, nossas construções subjetivas se mantêm em uma temporalidade em que a dor psíquica resultante de um processo de separação de um ente querido é algo trágico para o eu. Seja esta separação simbólica ou real, ela produz um dilaceramento do eu que é capaz de promover uma desestruturação do indivíduo e mudar todas as suas referências de tempo, de espaço e de identidade.

A dor psíquica é para Nasio (1997), o afeto que traduz na consciência a autopercepção pelo eu da comoção que ele sofre e assim, exprime o esgotamento de um eu que se mantém inteiramente ocupado em amar desesperadamente a imagem de um objeto perdido, seja esse um membro do corpo ou o amado eleito, num processo no qual a languidez e o amor se fundem em dor pura, expressando a máxima desorientação sentida, diante da mais extrema tensão interna. 
A dor psíquica desencadeada pela vivência da infidelidade do(a) parceiro(a) expressa a comoção pulsional ou autopercepção do eu sobre o tumulto interno desencadeado pela perda ou ruptura da imagem que o(a) parceiro(a) traído(a) tem de quem lhe foi infiel e, ao mesmo tempo, pela ruptura de sua própria imagem, gerando confusão mental e dúvidas sobre a própria identidade e sanidade mental. A dor é ainda demarcada pela familiaridade ou surpresa frente à um acontecimento que ameaça a perda do amado eleito; bem como é demarcada por uma espera, ou seja, um "luto" que vai lentamente levando o eu a desinvistir pouco a pouco, da figura do objeto amado.

Percebemos pois que, nas vivências relatas pelos(as) colaboradores(as), a irrepresentabilidade da dor psíquica pelo eu se expressa tanto pelo compartilhar interfantasmático que revela ao(à) cônjuge que seu(sua) parceiro(a) lhe é infiel ou pela marca súbita da descoberta de sua infidelidade, quanto pela "negação" da realidade.

Compreendemos também que a dor pode ser vivenciada numa relação sadomasoquista em que “o prazer em ver o outro sofrer”, gera prazer e, em conseqüência, mais dor, vivência tão pertinente no relato de Isolda.

É interessante notarmos que, embora o amor e dor sejam afetos tão enraizados no psiquismo e por isto se apresentam tão irrepresentáveis e inomináveis pela consciência humana, Flor de Liz é entre todos os colaboradores, masculinos e femininos, aquela que melhor exprime a delicadeza e a singeleza do sentimento amoroso quando realiza uma associação entre a dor fisica e a dor psíquica, ao significar a infidelidade do parceiro.

Percebemos entretanto que, a subtaneidade da notícia da infidelidade do(a) parceiro(a), tão desestruturadora das referências do $e u$, parece ser vivida de maneira diferente pelos homens e pelas mulheres. Enquanto os homens parecem desinvestir mais facilmente da figura da amada que lhe é infiel, utilizando-se do mecanismo de defesa 
chamado “racionalização” e, cumprindo com o papel de conservar a honra masculina ao abandonar a mulher adúltera, a dor psíquica vivenciada pelas mulheres parece ter uma íntima ligação com o “sentimento de culpa”.

Nessa relação entre dor e “culpa”, o ser feminino parece se manter facilmente preso ao ressentimento, desinvestindo muito lentamente da figura do amado eleito, assim como percebemos nas descrições de Isolda, Bárbara e Flor de Liz. O ressentimento leva o indivíduo a relembrar o agravo que o outro lhe fez e, paralisar assim, o processo de "luto".

Na descrição de Stela, vemos que uma característica fundamental, a extrema perda do amor-próprio, a sua melancolia, parece impedi-la de elaborar o “luto”.

A descrição de Stela aponta ainda para uma questão fundamental que vêm atualmente habitando o cenário afetivo e sexual, a transmissão de doenças sexualmente transmissíveis entre os parceiros conjugais. O medo de contrair doenças sexualmente transmissíveis foi revelado ainda por Flor de Liz.

Pudemos compreender também que, tanto na descrição relatada por Stela quanto na descrição relatada por Romeu a dramática ligação entre ciúme e violência compõe o cenário das relações infiéis, no qual um dos parceiros ou os dois expressam o desejo de dominar e controlar o outro. Percebemos que, a violência atualmente, seja esta física, psíquica ou moral existe entre os gêneros e não se refere somente a agressão do homem para com a mulher.

A dor psíquica desencadeada pela infidelidade do(a) parceiro(a) desvela também a manifestação exterior de sintomas refletidos em dores psicogênicas que revelam além da “culpa” e do ressentimento, sentimentos como menos-valia, impotência, insegurança, mágoa, ressentimento, solidão, abandono, rejeição, falta de apoio familiar e social e falta de perspectiva futura, bem como a projeção da dor psíquica no(a) parceiro(a). 
Segundo Dias (s/d), uma família que se ramifica, que se reconstitui ou que forma composições superpostas estaria exprimindo atualmente um apego ao modelo de família nuclear, cujo padrão patriarcal estabeleceu rígidas divisões hierárquicas entre os membros da família e prezou pela indissolubilidade do casamento. Em contrapartida, autores como Giddens (1993); Salém (1989); Vaitsman (1985); entre outros, apontam novas alternativas de se relacionar na família e na conjugalidade que imprimem um modo de se relacionar fundado em princípios individualistas-igualitários.

Entretanto, compreendemos nessa investigação que o modelo nuclear se expressa nos ideais dos casais contemporâneos no que diz respeito ao ideal de encontrar no casamento "a felicidade para sempre”. Percebemos porém que, a conjugalidade não se limita aos laços estabelecidos pelas regras da Igreja Católica e da Lei Civil, pois o compromisso da fidelidade vai além do "uso de alianças” ou das promessas formais.

As descrições analisadas nos mostram que, o desejo de fidelidade é pertinente nas relações entre os casais de namorados, bem como em outros tipos de uniões que fogem a regulamentação tradicional, como o caso de Ulisses e Cassandra que se casaram pelo contrato de conjunção marital.

Desse modo, podemos dizer que um mosaico de família redesenha a representação das parcerias amorosas na atualidade, e que nessas imagens, encontram-se junto aos modelos alternativos, a ressonância dos ideais tradicionais.

Os valores, as regras e os mitos que regem um grupo familiar são transmitidos de pais para filhos, de geração à geração. E, além disto, percebemos também que uma ligação entre a preocupação com os filhos e o desejo de se separar ou não se separar do(da) parceiro(a) são pertinentes em uma situação de conflito conjugal. 
É importante ainda dizermos que, embora a mulher ter adentrado no mercado de trabalho e ser capaz de redirecionar seus projetos pessoais buscando satisfações em outros terrenos que não se refiram somente ao casamento, o amor romântico que foi base do casamento burguês, imprime atualmente as idealizações de felicidade nas parcerias. As representações psíquicas referentes aos ideais amorosos se constroem por meio dos ideais românticos de exclusividade e eternidade do amor e, compreendemos que é justamente a ruptura desse ideal que provoca os desencantamentos de homens e mulheres frente ao amado eleito.

A quebra da idealidade frente à figura amada que re-centra os desencantos vivenciados pelos homens e pelas mulheres entrevistados(as) por nós, se manifesta também nas insatisfações sexuais, as quais procuram se manter veladas entre os parceiros conjugais.

Autores como Lipovetsky (2004); Hall (2002), entre outros, afirmam que o indivíduo contemporâneo vivencia uma crise de identidade proveniente de uma crise de identidade cultural. Percebemos pois que, os paradoxos que enceram a vivencia cotidiana de homens e mulheres na contemporaneidade no que diz respeito as questões afetivas e sexuais são reflexos dos paradoxos sociais, pois dúvidas quanto à tomada de decisões, desilusões e incertezas são vividas também nos cenários amorosos.

Contudo, as re-significações existenciais frente à vivencia da infidelidade podem percorrer territórios psíquicos que se dirigem para duas instâncias: a reconstrução e/ou dissolução do relacionamento amoroso, na busca de vivencias prazerosas; o aprisionamento da dor que encerra o eu em um dilaceramento sem fim, preso a uma antiga imagem não resignificada do eleito amado.

Cumprindo com nosso objeto, dizemos ainda que, esse trabalho poderá possibilitar a compreensão do fenômeno da infidelidade e da re-significação da relação amorosa feita por 
homens e mulheres à profissionais da área da Psicologia, da Psicanálise, da Sociologia, da Educação, da Filosofia e da Fenomenologia, além de possibilitar contribuições significativas para a sociedade de modo geral, proporcionando reflexões sobre o modo como vêm ocorrendo as relações afetivas e sexuais, sobre as relações de gêneros e sobre a própria Educação Sexual, no momento atual.

Contudo, outras reflexões podem ser vislumbradas, como veremos a seguir:

\section{HORIZONTES}

Buscando vislumbrar os horizontes que poderão ser percorridos a partir das múltiplas significações atribuídas a vivência da infidelidade amorosa do(a) parceiro(a) e da re-significação da relação afetiva e sexual por homens e mulheres na atualidade, fizemos ainda algumas reflexões.

Ao realizamos um enlace entre a Fenomenologia e a Psicanálise ao utilizarmos uma disciplina enquanto metodologia de pesquisa e a outra, enquanto referencial teórico interpretativo, pudemos compreender o fenômeno indagado em uma compreensão psicológica que se estabelece na relação entre o fenômeno, as tramas intersubjetivas e o mundo. E além disto, abrimos um caminho para que outras práticas de pesquisas sejam desenvolvidas a partir dos referenciais teóricos utilizados por nós.

Podemos dizer também que, o fenômeno aqui estudado ainda poderia ser compreendido mediante muitas outras significações, de modo que ainda poderíamos ampliar a sua compreensão.

Além disso, compreendemos que, ao tratarmos de afetos tão significativos para o ser humano, essa investigação poderá contribuir de maneira especial para a inter-relação entre o conhecimento científico e a prática clínica, oferecendo aos profissionais instrumentações 
teóricas no que diz respeito ao entendimento de homens e mulheres que vivenciam em suas relações cotidianas, a infidelidade amorosa.

Visto que a infidelidade não se refere simplesmente as relações regulamentadas pelas práticas religiosas e pelo direito civil, podemos ainda indagar: “como será que é para os adolescentes a percepção acerca da infidelidade amorosa na atualidade?”; “e para os casais homossexuais e bissexuais?; "e para os casais mais velhos, como vêm vivenciando as suas relações afetivas e sexuais e os desencantos da infidelidade?”.

Poderíamos ainda ter nos conduzido pelo outro lado da verdade: “que significados teriam atribuído às suas vivências infiéis os(as) parceiros(as) de Isolda, Bárbara, Stela, Flor de Liz, Romeu, Ulisses, Aquiles e Paris, caso tivessem sido entrevistados por nós?”.

Acreditando que um fenônemo nunca pode ser alcançado em seu sentido pleno, dizemos ainda que, é sempre preciso e possível recomeçar.

"De tudo ficaram três coisas: A certeza de que estamos começando, A certeza de que é preciso continuar e A certeza de que podemos ser interrompidos antes de terminar Fazer da interrupção um caminho novo, Da queda um passo de dança, Do medo uma escola, Do sonho uma ponte, Da procura um encontro, E assim terá valido a pena existir!". 


\section{REFERÊNCIAS BIBLIOGRÁFICAS}

AMATUZZI, M.M. Pesquisa fenomenológica em psicologia. IN: BRUNS, M.A.T.; HOLANDA, A.F. (Orgs.) Psicologia e pesquisa fenomenológica - reflexões e perspectivas. São Paulo: Omega, 2003. p. 15-22.

ARANHA, M. L.; MARTINS, M. L. P. Filosofando: Introdução à Filosofia. São Paulo: Moderna, 1986.

ARAÚJO, M. F.; MARTINS, E. J. S.; SANTOS, A. L. Violência de gênero e violência contra a mulher. IN: ARAÚJO, M. F.; MATTIOLI, O. C. (Orgs.). Gênero e violência. São Paulo: Arte \& Ciência, 2004.

ARIÈS, P. História Social da Criança e da família. Rio de Janeiro: Guanabara, 1981.

BAKER, R. Guerra de esperma: infidelidade, conflito sexual e outras batalhas de alcova. Tradução de Gabriel Zide Neto. - Rio de Janeiro: Record, 1997.

BAUMAN, Z. Amor Líquido: Sobre a fragilidade dos laços humanos. Tradução de Carlos Alberto Medeiros. Rio de Janeiro: Jorge Zahar Ed., 2004.

BAUMAN, Z. O mal-estar da pós-modernidade. Rio de Janeiro: Jorge Zahar Ed., 1998.

BERENSTEIN, I. Família e doença mental. Tradução de Adriana Friedmann. São Paulo: Editora Escuta, 1988.

BIRMAN, J. Mal-estar na atualidade. Rio de Janeiro: Record, 1999. 
Ensaios de teoria psicanalítica, 1. parte: metapsicologia, pulsão, linguagem, inconsciente e sexualidade. Rio de Janeiro: Jorge Zahar Ed., 1993.

BOGDAN, R. C; BIKLEN, S. K. Investigação qualitativa em educação: Uma introdução à teoria e aos métodos. Porto: Porto Editora, 1997.

BORBA, F. S. (Org.) Dicionário UNESP de português contemporâneo. São Paulo: Editora UNESP, 2004.

BRUNS, M. A. T. O pesadelo da traição virtual. Jornal Campinas Café, Campinas, São Paulo, fevereiro de 2006, ano 12, $\mathrm{n}^{\circ}$ 136, seção comportamento, p.02.

BRUNS, M. A. T.; ALMEIDA, S. Sexualidade-preconceito, tabus, mitos e curiosidades. Campinas: Editora Átomo, 2004.

BRUNS, M. A. T. A redução fenomenológica em Husserl e a possibilidade de superar impasses da dicotomia subjetividade-objetividade IN: BRUNS, M.A.T.; HOLANDA, A.F. (Orgs.) Psicologia e fenomenologia - reflexões e perspectivas. São Paulo: Alínea, 2003. p. 57-66.

BRUNS, M. A. T.; PEREIRA, V. M. A. Gravidez e sexualidade: a vivência de mitos e tabus. Relatos de homens e mulheres. In: Revista Brasileira de Sexualidade Humana, Vol.12, n¹, 2001, p.84-105.

BUCCI, E.; KEHL, M. R. Videologias: ensaios sobre televisão. São Paulo: Boitempo Editorial, 2004.

CARUSO, I. A. A separação dos amantes: uma fenomenologia da morte. Tradução de João Silvério Trevisan. $4^{\mathrm{a}}$ ed. São Paulo: Diadorim: Cortez, 1986. 
Charles deverá pedir perdão ao ex-marido de Camilla por traição. Tudodibão. Disponível em: <http://revistaepoca.globo.com/Epoca/0,6993,EPT945266-1661,00.html>. Acesso em: 14 jun. 2005.

CHAUÍ, M. Prefácio. In: Videologias: ensaios sobre televisão. São Paulo: Boitempo, 2004, p. 07-13.

. Convite à filosofia. São Paulo: Ática, 2001.

. Repressão Sexual: essa nossa (des) conhecida. São Paulo: Brasiliense, 1991.

CHEMANA, R. (Org.) Dicionário de psicanálise. Tradução de Francisco Franke Settineri: Porto Alegre: Artes Médicas Sul, 1995.

COMTE-SPONVILlE, A. Pequeno tratado das grandes virtudes. São Paulo: Martins Fontes, 1995.

COSTA, J. F. Sem fraude nem favor: Estudos sobre o amor romântico. Rio de Janeiro: Rocco, 1998.

COSTA, R. O. Os onze sexos: as múltiplas faces da sexualidade humana. São Paulo: Editora Gente, 1994.

DEBORD, G. A sociedade do espetáculo: comentários sobre a sociedade do espetáculo. Tradução de Estela dos Santos Abreu. Rio de Janeiro: Contraponto, 1997.

DEBUS, M. Manual para excelencia en la investigavión mediante grupos focales. Washington: Health Com Agengy for Internacional Development. [mimeo] 1994, 97 p. 
DIAS, M. L. Divórcio e reconstituição familiar no Brasil. [mimeo]. (s/d). 14 p.

DUBY, G. História da Vida Privada, v. 2 : da Europa Feudal à Renascença. São Paulo: Companhia das Letras, 1990.

DUROZOI, G.; ROUSSEL, A. Dicionário de filosofia. Tradução de Maria Appenzeller. Campinas: Papirus, 1993.

EIGUER, A. O parentesco fantasmático: transferência e contratransferência em terapia familiar. São Paulo: Casa do Psicólogo, 1985.

EIGUER, A. Os dispositivos psicanalíticos e as incidências da geração. IN KAES, R. A. A transmissão do psiquismo entre gerações: enfoque em terapia familiar psicanalítica. São Paulo: Unimarco, 1998.

FADIMAN, J. Teorias da personalidade. Tradução de Camila Pedral Sampaio, $1^{\mathrm{a}}$ edição, São Paulo: Editora Harbra, 1979.

FORGHIERI, Y. C. Psicologia fenomenológica: fundamentos, método e pesquisa. São Paulo: Pioneira Thomson Learning, 2001.

FREUD, S. (1915). Luto e melancolia. Edição Standard Brasileira das Obras Psicológicas de Sigmund Freud. Rio de Janeiro: Imago, 1976.

. (1926). Inibição, sintoma e angústia. Edição Standard Brasileira das Obras Psicológicas de Sigmund Freud. Rio de Janeiro: Imago, 1976. 
(1930). O mal-estar na cultura. Edição Standard Brasileira das Obras Psicológicas de Sigmund Freud. Rio de Janeiro: Imago, 1976.

GARCIA-ROZA. L. A. Pesquisa de tipo teórico. IN: Psicanálise e Universidade. Atas do I Encontro de Pesquisa Acadêmica em Psicanálise, do Núcleo de Pesquisa em Psicanálise do Programa de Estudos de Pós-Graduados em Psicologia Clínica, do Instituto de Psicologia da Pontifica Universidade Católica -PUC-SP, realizado sob a coordenação de Luís Cláudio Figueiredo, São Paulo, 1991, p.9-32.

GIKOVATE, F. Ensaios sobre o amor e a solidão. $6^{a}$ edição revista. São Paulo: MG Editores, 2006.

GIORGI, A. A Psicologia como ciência humana: Uma abordagem de base fenomenológica. Belo Horizonte: Interlivros, 1978.

GONÇALVES, C. R. Sinopses jurídicas: Direito de família. São Paulo: Saraiva, 2002.

GIDDENS, A. A transformação da intimidade. Sexualidade, amor e erotismo nas sociedades modernas. São Paulo: Ed. UNESP, 1993.

A. As conseqüências da modernidade. São Paulo: Ed. UNESP, 1991.

HALL, S. A identidade cultural na pós-modernidade. Tradução Tomaz Tadeu da Silva, Guaracira Lopes Louro. 7.ed. Rio de Janeiro: DP\&A, 2002.

HARVEY, D. Condição pós-moderna. São Paulo: Edições Loyola, 1992.

HEIDEGGER, M. O ser e o tempo. Petrópolis: Vozes, 1971. 
HERRMANN, F. Clínica psicanalítica: a arte da interpretação. São Paulo: Editora Brasiliense, 1991.

KEHL, M. R. Ressentimento. São Paulo: Casa do Psicólogo, 2004.

LAPLANCHE, J.; PONTALIS, J. B. Vocabulário de psicanálise. São Paulo: Martins Fontes, 2001.

LÉVI-STRAUSS, C. As estruturas Elementares do Parentesco. Tradução de Mariano Ferreira. São Paulo: Ed. Universidade de São Paulo, 1980.

LINS, R. N. A cama na varanda: arejando nossas idéias a respeito de amor e sexo. Rio de Janeiro: Rocco, 1997.

LIPOVETSKY, G. Os tempos hiper-modernos. Tradução de Mário Vilela. São Paulo: Editora Barcarolla, 2004.

LOYOLA, M. A. A sexualidade como objeto de estudo das ciências humanas. In: HEILBORN, M.L. (Org.). Sexualidade: o olhar das ciências sociais. Rio de Janeiro: Jorge Zahar, 1999. p. 31-39.

LUZ, M. O vazio nas relações sociais na cultura atual. In: POIAN, C. da (Org.). Formas do vazio: desafios ao sujeito contemporâneo. São Paulo: Via Lettera Editora e Livraria, 2001, p. 29-66.

MARCHELLO-NIZIA, C. Cavalaria e cortesia. In: LEVI, G.; SCHMITT, J-C. (Orgs.), História dos jovens: da Antigüidade à Era Moderna São Paulo: Companhia das Letras, 1996. v.1, p.141-190. 
MARTUSCELLO, C. O teatro de Nelson Rodrigues. Editora Siciliano, São Paulo: 1993.

MAYAN, M. Una Introducción a los Métodos Cualitativos: Un Módulo de Entrenamiento para Estudiantes y Profesionales - traducido al españ com unanota introductoria de César A. Cisneros Puebla. Iztapalapa, México. Disponível em: http://www.ualberta.ca/ iiqm//pdfs/introduccion.pdf. Acesso em: 2001.

MINAYO, M. C. S. O desafio do conhecimento científico: pesquisa qualitativa em saúde. $2^{a}$ edição. SP-RJ: Hicitec-Abrasco, 1994.

MOREIRA, A. C. G. Clínica da melancolia. São Paulo: Escuta/Edufpa, 2002.

NASIO, J.D. Como trabalha um psicanalista?. Traduação de Lucy Magalhães. Rio de Janeiro: Jorge Zahar, 1999.

Cinco lições sobre a teoria de Jacques Lacan. Tradução de Vera Ribeiro. Rio de Janeiro: Jorge Zahar, 1993.

O livro da dor e do amor. Tradução de Lucy Magalhães. Rio de Janeiro: Jorge Zahar Ed., 1997.

PAZ, O. A dupla chama: amor e erotismo. Tradução de Wladir Dupont. São Paulo: Siciliano, 2001.

PINCUS, L.; DARE, C. Psicodinâmica da família. Tradução de Clara Rotenberg e Shirley Kleinke. Porto Alegre: Artes Médicas: 1978. 
REZENDE, A. M. Concepção fenomenológica da educação. São Paulo: Cortez: Autores Associados, 1990.

Romance de Charles e Camilla vai virar filme. Revista Época. Disponível em: <http://revistaepoca.globo.com/Epoca/0,6993,ЕPT945266-1661,00.html>. Acesso em: 14 jun. 2005.

ROUDINESCO, E.; PLON, M. Dicionário de Psicanálise. Tradução Vera Ribeiro, Lucy Magalhães. Supervisão da edição brasileira Marco Antônio Coutinho Jorge. Rio de Janeiro: Jorge Zahar Ed., 1998.

SALÉM, T. O casal igualitário: princípios e impasses. Revista Brasileira de Ciências Sociais. Rio de Janeiro. v. 3, n 9, p.24-37, fevereiro, 1989.

SIBONY, D. Divisor de águas. In: CZECHOWSKY, N. (Org.). A fidelidade: um horizonte, uma troca, uma memória. Tradução de Moacyr Gomes Jr. Porto Alegre: L\&PM, 1992, p. 13-24.

SILVA, N. P. Entre o público e o privado: um estudo sobre a fidelidade à palavra empenhada. São Paulo: 2002, 353 p. Tese (Doutorado). Instituto de Psicologia da Universidade de São Paulo - USP, SP.

SILVA, R. de C. A falsa dicotomia qualitativo - quantitativo: paradigmas que informam nossas práticas de pesquisa. In: ROMANELLI, G.; BIASOLI-ALVES, Z. M. (Orgs.). Diálogos Metodológicos sobre prática de pesquisa. Ribeirão Preto: Segis Summa, 1998.

SILVEIRA, N. Imagem do inconsciente. Rio de Janeiro: Editora Alhambra, 1982. 
TELLES, S. O psicanalista vai ao cinema: artigos e ensaios sobre psicanálise e cinema. São Carlos, São Paulo: Editora UFSCar, 2004.

TORRES, A. A individualização no feminino, o casamento e o amor. In: PEIXOTO, C.; SINGLY, F. de e CICHELLI, V. (Orgs.). Família e individualização. Rio de Janeiro: Ed. FGV, 2002. p. 135-154.

VAINFAS, R. Casamento, amor e desejo no ocidente cristão. São Paulo: Ática, 1986.

VAITSMAN, J. Casal, sim, mas cada um na sua casa. Jornal do Brasil, Rio de Janeiro, Caderno Especial. Julho, 1985.

VAITSMAN, J. Flexíveis e plurais: identidade, casamento e família em circunstâncias pós- modernas. Rio de Janeiro: Rocco, 1994.

VALLES, M. S. Técnicas cualitativas de investigacion social: reflexion metodológica e prática profesional. Madrid: Ed. Sintesis Sociología, 1997.

WAJSBROT, C. Prefácio. In: CZECHOWSKY, N. (Org.) 1992. A fidelidade: um horizonte, uma troca, uma memória. Tradução de Moacyr Gomes Jr. Porto Alegre: L\&PM, p. $7-12$.

WRIGHT, R. O animal moral - por que somos como somos: a nova ciência da psicologia evolucionista. Tradução Lia Wyler. Rio de Janeiro: Campus, 1996.

ZAMPIERI, A. M. F. Erotismo, sexualidade, casamento e infidelidade: sexualidade conjugal e prevenção do HIV e da AIDS. São Paulo: Agora, 2004. 
ANEXOS 
Of.CEtP/028/2003/02.06.2003

Senhora Pesquisadora:

Comunicamos a V. Sa. que o trabalho intitulado "DESvElando A DOR AMOROSA DA INFIDELIDADE CONJUGAL: DISCURSOS DE HOMENS E MULHERES", foi analisado peio Comitè de Ética em Pesquisa da FFCLRP-USP, em sua $28^{\mathrm{a}}$ Reuniāo Ordinária. reatizada em 28/05/2003. e enquadrado na categoria: APROVADO, de acordo com o Processo CEP-FFCLRP $n^{\circ} 091 / 2003-$

Aproveitamos a oportunidade para apresentar nossos protestos de estima e consideraçâo.

Atenciosamente.

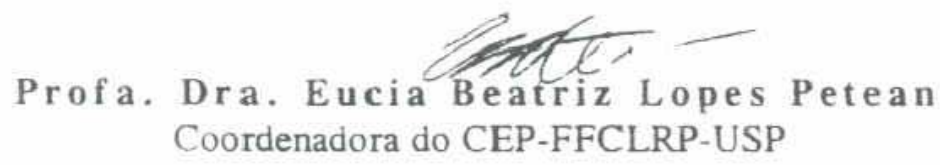

Ilustrissima Senhora

Edilaine Helena Scabello

Departamento de Psicologia e Educação - FFCLRP-USP

Cópia para Profa. Dra. Maria Alves de Toledo Bruns

CEP-FFCLRP-USP - Fone: (016) 602-3670 / 6023644 - Fax: (^16) 633-2660 (direto) Avenida Bandeirantes, 3900 - Bloco A - 14040-901 - Ribeirão Preto - SP - Brasil 
Anexo B

\section{UNIVERSIDADE DE SÃO PAULO \\ Faculdade de Filosofia, Ciências e Letras de Ribeirão Preto \\ Departamento de Psicologia e Educação \\ Programa de Pós-graduação em Psicologia}

Seção de Pós-Graduação - Fone: (0xx16)602-3675/602-3681 - Fax: (0xx16)633-6361/633-5015

Av. bandeirantes, 3900 - CEP.14.040-901 - Ribeirão Preto - SP

TERMO DE CONSENTIMENTO LIVRE E ESCLARECIDO

(De acordo com a Resolução n 196/96 sobre Pesquisa Envolvendo Seres Humanos do

Conselho Nacional de Saúde - Ministério da Saúde - Brasília-DF)

\section{Título da Pesquisa:}

“Desvelando a dor amorosa da infidelidade conjugal: discursos de homens e mulheres".

Pesquisadora Responsável: Edilaine Helena Scabello

Registo Civil: $26.236 .740-3$

CIC: $260571698-83$

Registro Profissional: $C R P-06 / 59371$

Orientadora da Pesquisa: Profa. Dra. Maria Alves de Toledo Bruns

Endereço: Departamento de Psicologia e Educação - Seção de Pós-graduação - Faculdade de Filosofia, Ciências e Letras de Ribeirão Preto - USP

Av. bandeirantes, 3900 - Ribeirão Preto - SP

Cep: $14.040-901$

Tel: (0xx16)602-3675/602-3681

Fax: : (0xx16)633-6361/633-5015

E-mail: toledobruns@uol.com.br

Descrever abaixo as informações dadas aos colaboradores da pesquisa:

1. Justificativa, objetivo e procedimentos que serão utilizados na pesquisa;

2. Desconfortos, riscos possíveis e benefícios esperados;

3. Garantia de esclarecimentos antes e durante a entrevista, sobre quaisquer dúvidas;

4. Garantia de sigilo assegurando a privacidade do colaborador; 
5. Liberdade do colaborador de recusar a participar ou retirar seu consentimento após a entrevista, sem penalização alguma ou prejuízo ao seu cuidado.

As informações supracitadas devem ser redigidas em termos simples, conhecidos pelos colaboradores e de forma que possam entender:

Sou psicóloga e realizo uma pesquisa em nível de Mestrado chamada: "Desvelando a dor amorosa da infidelidade conjugal: discursos de homens $e$ mulheres."Esta pesquisa vem sendo supervisionada por uma professora pertencente ao Programa de Pós-graduação em Psicologia da FFCLRP/USP da qual eu sou aluna.

\section{Objetivos:}

O objetivo dessa pesquisa é compreender o que significa infidelidade amorosa hoje em dia, isto é, como homens e mulheres casados pela Lei Civil e pela Igreja Católica vivenciam a traição do cônjuge.

\section{Justificativas:}

Essa pesquisa é importante porque apesar dos casais jurarem fidelidade amorosa ao parceiro, muitos casais traem e, mesmo diante da dor de terem sido traídos muitos casais não se separam.

Além disto, essa pesquisa poderá contribuir para que profissionais que trabalham ou estudam sobre essa questão possam saber mais a respeito desse assunto e até modificar suas idéias a respeito.

\section{Procedimentos:}

Entrevistaremos 06 (seis) homens e 06 (seis) mulheres, heterossexuais, casados pela lei Civil e pela Igreja Católica que foram traídos (as) pelo (a) parceiro (a), pelo menos uma vez e continuaram unidos a ele (ela) em matrimônio. Os homens e as mulheres não serão casados entre si e terão se casado uma única vez. A idade dos colaboradores poderá variar entre 35 e 45 anos, o tempo de casado de 02 a 27 anos, o grau de escolaridade do ensino fundamental incompleto ao ensino superior completo, o número de filhos será em média 03, e o nível sócio-econômico, a média renda.

O local e o horário da entrevista é escolhido pelo (a) colaborador (a0 da pesquisa, podendo ou não aceitar alguma sugestão da pesquisadora.

No caso do (a) colaborador (a) ter sido contatada através de alguma instituição clínica de atendimento psicológico e estar sob atendimento, a entrevista será realizada na própria instituição, na data e horário a ser combinado entre o (a) colaborador (a), a pesquisadora e de acordo com a disponibilidade do local.

Sendo assim, gostaria de entrevistá-la para que eu possa alcançar meus objetivos.

A entrevista será realizada com uma única questão, a qual perguntarei de várias maneiras, na qual a Sra. terá liberdade para falar o que quiser no tempo que lhe for necessário.

Gostaria de gravar o seu depoimento. Peço sua autorização para isto e, caso não queria que ele seja gravado ele poderá ser escrito por mim. Depois da entrevista seu depoimento será transcrito e os dados colhidos através dele serão analisados por mim.

Caso lhe surja alguma dúvida no decorrer da entrevista, poderei esclarecê-la.

Garantia de sigilo, direitos, riscos e benefícios esperados: 
Sua identidade será preservada não sendo possível o seu reconhecimento, ou o de qualquer pessoa da qual citar o nome, pois os nomes serão mantidos em sigilo $e$ substituídos por nomes fictícios.

Os dados obtidos através do seu depoimento depois de analisados farão parte de minha dissertação de mestrado, e poderão ser lidos por aqueles que estudam o assunto ou quaisquer outras pessoas interessadas pelo tema.

Os dados obtidos poderão ainda serem utilizados em artigos de interesse científico.

Caso seja necessário e o (a) Sr. (Sra.) me autorize, realizarei mais uma entrevista a fim de que o (a) Sr. (Sra.) possa esclarecer-me algumas dúvidas que possam surgir a respeito da primeira entrevista. Neste caso, se após a leitura da entrevista transcrita surgirem tais dúvidas entrarei em contato com o (a) Sr. (Sra) para realizarmos a segunda entrevista.

Como estamos tratando de uma assunto delicado que é a infidelidade conjugal, do qual lhe poderá despertar lembranças e sentimentos inesperados ao falar do assunto, mesmo após a(s) entrevista(s) concluída(s) o (a) Sr. (Sra.) decida retirar o seu consentimento em vista do que tenha dito, isto poderá ser feito sem qualquer penalização ou prejuízo ao seu cuidado.

Antes de iniciarmos a entrevista o (a) Sr. (Sra.) deverá datar e assinar ao Termo de Consentimento Livre e Esclarecido declarando que me autoriza a entrevistá-lo (la). Este termo também é assinado pela pesquisadora, sendo que existem duas cópias, uma delas ficará com a colaboradora e a outra arquivada com a pesquisadora.

A questão é a seguinte: "Fale a respeito da sua relação afetiva e sexual no decorrer do seu casamento e, em especial, após seu marido (esposa) lhe ter sido infiel”.

Caso não tenha compreendido a questão, farei a mesma pergunta de outras maneiras: "Fale para mim como era sua vida afetiva e sexual com o (a) seu (sua) marido (esposa/namorada) antes dele (a) lhe ter sido infiel. E como é agora?"; "Fale para mim o que significou para o Sr. (Sra.) ter sido traído (a)?”. 
Eu, (Nome do (a) colaborador (a))

R.G. $n^{\circ}$ após tomar conhecimento das informações referentes à

minha disposição em participar dessa pesquisa e, ciente dos meus direitos abaixo relacionados, concordo em participar da pesquisa: “Desvelando a dor amorosa da infidelidade conjugal: discursos de homens e mulheres”, declarando conhecer os termos da Pesquisa, bem como afirmo que minha participação é totalmente espontânea e livre.

1. Estamos de acordo com o local e o horário da entrevista, bem como a forma com que será feita.

2. Sendo uma pesquisa que envolve conteúdos pessoais e íntimos, conheço a garantia de que o meu nome e o de outras pessoas citadas em meu depoimento, não aparecerão em momento algum na pesquisa, mantendo-se sigilo completo da entrevista.

3. A qualquer momento em que eu deseje interromper minha fala ou desistir de dar meu depoimento serei prontamente atendido mesmo após a entrevista concluída.

4. ( ) Autorizo gravar o meu depoimento.

( ) Não autorizo gravar o meu depoimento.

5. ( ) Autorizo a realização de uma segunda entrevista caso seja necessário esclarecer dúvidas da pesquisadora.

( ) Não autorizo a realização de uma segunda entrevista.

Nome do colaborador (a):

Endereço:

CEP:

Tel:

Fax:

E-mail:

Assinatura da entrevistada:

Assinatura da pesquisadora:

Data da $2^{\mathrm{a}}$ entrevista:

de de 200 


\section{Anexo C}

\section{Roteiro para obtenção de informações para caracterizar o perfil do (a)}

\section{colaborador (a)}

1. Pseudônimo do (a) colaborador (a):

2. Idade:

3. Religião atual:

Religião de origem:

4. Grau de instrução:

5. Área de atuação:
Idade do (a) (ex) parceiro (a):

Religião atual do (a) (ex) parceiro (a):

Religião de origem do (a) (ex) parceiro (a):

Grau de instrução do (a) (ex) parceiro (a):

Área de atuação do (a) (ex) parceiro (a):

6. Dados matrimoniais

Tipo de casamento: Civil ( ) Religioso ( ) Conjunção Marital ( )

Idade em que o casal se casou: Colaborador (a) parceiro (a):

Ano em que o casal se casou:

Número de filhos, idade e sexo dos filhos:

7. No caso de ter havido separação:

Tipo de separação:

Ano em que ocorreu a separação:

Houve reconciliação? Quando?

8. No caso do colaborador ter namorado ou estar namorando

Duração do namoro: 


\section{Anexo D}

\section{Questionário de classificação econômica}

\section{Quem é o chefe da família?}

( ) o próprio colaborador (a) ( )outrem:

2. Qual o grau de instrução do chefe da família?

\begin{tabular}{|l|l|}
\hline Analfabeto / Primário incompleto & 0 \\
\hline Primário completo / Ginasial incompleto & 1 \\
\hline Ginasial completo / Colegial incompleto & 2 \\
\hline Colegial completo / Superior incompleto & 3 \\
\hline Superior completo & 5 \\
\hline
\end{tabular}

\section{Quais itens abaixo a sua casa possui?}

\begin{tabular}{|l|l|l|l|l|c|}
\hline & Nenhum & $\mathbf{1}$ & $\mathbf{2}$ & $\mathbf{3}$ & $\begin{array}{c}\mathbf{4} \\
\text { ou } \\
+\end{array}$ \\
\hline Televisão em cores & & & & \\
\hline Rádio & 0 & 2 & 3 & 4 & 5 \\
\hline Banheiro & 0 & 1 & 2 & 3 & 4 \\
\hline Automóvel & 0 & 2 & 3 & 4 & 4 \\
\hline Empregada mensalista & 0 & 2 & 4 & 5 & 5 \\
\hline Aspirador de pó & 0 & 2 & 4 & 4 & 4 \\
\hline Máquina de lavar & 0 & 1 & 1 & 1 & 1 \\
\hline Videocassete e/ou DVD & 0 & 1 & 1 & 1 & 1 \\
\hline Geladeira & 0 & 2 & 2 & 2 & 2 \\
\hline Freezer & 0 & 2 & 2 & 2 & 2 \\
\hline & 0 & 1 & 1 & 1 & 1 \\
\hline
\end{tabular}

CORTES DO CRITÉRIO BRASIL

\begin{tabular}{|c|c|c|}
\hline Classe & Pontos & $\begin{array}{c}\text { Total } \\
\text { Brasil (\%) }\end{array}$ \\
\hline A1 & $30-34$ & 1 \\
\hline A2 & $25-29$ & 5 \\
\hline B1 & $21-24$ & 9 \\
\hline B2 & $17-20$ & 14 \\
\hline $\mathrm{C}$ & $11-16$ & 36 \\
\hline $\mathrm{D}$ & $6-10$ & 31 \\
\hline $\mathrm{E}$ & $0-5$ & 4 \\
\hline
\end{tabular}

Critério de Classificação Econômica Brasil de acordo com a ANEP (www.anep.org.br) 
Anexo E

\begin{abstract}
UNIVERSIDADE DE SÃO PAULO
Faculdade de Filosofia, Ciências e Letras de Ribeirão Preto

Departamento de Psicologia e Educação

Programa de Pós-graduação em Psicologia
\end{abstract}

Seção de Pós-Graduação - Fone: (0xx16)602-3675/602-3681 - Fax: (0xx16)633-6361/633-5015

Av. bandeirantes, 3900 - CEP.14.040-901 - Ribeirão Preto - SP

\title{
AUTORIZAÇÃO PARA UTILIZAÇÃO, VEICULAÇÃO E REPRODUÇÃO DE IMAGENS FOTOGRÁFICAS
}

$\mathrm{Eu}$, RG número

autorizo a utilização e a veiculação das minhas fotografias pessoais de casamento, cuja cerimônia ocorreu no dia nos exames de qualificação e defesa do trabalho intitulado "Desvelando a dor amorosa da infidelidade conjugal: discursos de homens $e$ mulheres”, desenvolvido pela pesquisadora Edilaine Helena Scabello, sob a orientação da Profa. Dra. Maria Alves de Toledo Bruns, docente do Programa de Pós-graduação em Psicologia do Departamento de Psicologia e Educação, da FFCLRP - USP.

Ribeirão Preto, 20 de fevereiro de 2005. 


\author{
Anexo F \\ UNIVERSIDADE DE SÃO PAULO \\ Faculdade de Filosofia, Ciências e Letras de Ribeirão Preto \\ Departamento de Psicologia e Educação \\ Programa de Pós-graduação em Psicologia \\ Seção de Pós-Graduação - Fone: (0xx16)602-3675/602-3681 - Fax: (0xx16)633-6361/633-5015 \\ Av. bandeirantes, 3900 - CEP.14.040-901 - Ribeirão Preto - SP
}

\title{
AUTORIZAÇÃO PARA REPRODUÇÃO DE IMAGENS FOTOGRÁFICAS NO TEXTO FINAL DA PESQUISA COMO ELEMENTO ILUSTRATIVO
}

$\mathrm{Eu}$, RG número

autorizo a utilização e reprodução de minha fotografia pessoal de casamento, cuja cerimônia ocorreu no dia , como elemento ilustrativo na capa da dissertação intitulada "Desvelando a dor amorosa da infidelidade conjugal: discursos de homens $e$ mulheres", desenvolvida pela pesquisadora Edilaine Helena Scabello, sob a orientação da Profa. Dra. Maria Alves de Toledo Bruns, docente do Programa de Pós-graduação em Psicologia do Departamento de Psicologia e Educação, da FFCLRP - USP.

Ribeirão Preto, 20 de fevereiro de 2006. 